UNIVERSIDADE DE SÃO PAULO

FACULDADE DE FILOSOFIA, LETRAS E CIÊNCIAS HUMANAS

DEPARTAMENTO DE LETRAS CLÁSSICAS E VERNÁCULAS

ÁREA DE FILOLOGIA E LÍNGUA PORTUGUESA

\title{
UM ESTUDO DE METÁFORAS TERMINOLÓGICAS PRESENTES EM GÊNEROS ACADÊMICOS DA ECONOMIA: ASPECTOS LINGUÍSTICOS, COMUNICATIVOS E COGNITIVOS
}

\author{
VERSÃO CORRIGIDA
}

ELENICE ALVES DA COSTA

SÃO PAULO 


\section{UM ESTUDO DE METÁFORAS TERMINOLÓGICAS PRESENTES EM GÊNEROS ACADÊMICOS DA ECONOMIA: ASPECTOS LINGUÍSTICOS, COMUNICATIVOS E COGNITIVOS}

\section{VERSÃO CORRIGIDA}

Tese apresentada ao Departamento de Letras Clássicas e Vernáculas da Faculdade de Filosofia, Letras e Ciências Humanas, da Universidade de São Paulo para obtenção do título de Doutora em Língua Portuguesa

Orientadora: Prof. ${ }^{a}$ Dr. ${ }^{a}$ Ieda Maria Alves

\section{São Paulo}


Autorizo a reprodução e divulgação total ou parcial deste trabalho, por qualquer meio convencional ou eletrônico, para fins de estudo e pesquisa, desde que citada a fonte.

Catalogação na Publicação

Serviço de Biblioteca e Documentação

Faculdade de Filosofia, Letras e Ciências Humanas da Universidade de São Paulo

Costa, Elenice Alves da

C837e UM ESTUDO DE METÁFORAS TERMINOLÓGICAS PRESENTES EM GÊNEROS ACADÊMICOS DA ECONOMIA: ASPECTOS

LINGUÍSTICOS, COMUNICATIVOS E COGNITIVOS / Elenice

Alves da Costa ; orientador Ieda Maria Alves. - São Paulo, 2020 .

$191 \mathrm{f}$.

Tese (Doutorado)- Faculdade de Filosofia, Letras e Ciências Humanas da Universidade de São Paulo. Departamento de Letras Clássicas e Vernáculas. Área de concentração: Filologia e Língua Portuguesa.

1. Metáfora. 2. Terminologia. 3. Economia. 4. Ciência. 5. Cognição. I. Alves, Ieda Maria, orient. II. Título. 


\title{
ENTREGA DO EXEMPLAR CORRIGIDO DA DISSERTAÇÃO/TESE \\ Termo de Ciência e Concordância do (a) orientador (a)
}

\author{
Nome do (a) aluno (a): Elenice Alves da Costa
}

Data da defesa: 26/10/2020.

Nome do Prof. (a) orientador (a): Ieda Maria Alves

Nos termos da legislação vigente, declaro ESTAR CIENTE do conteúdo deste EXEMPLAR CORRIGIDO elaborado em atenção às sugestões dos membros da comissão Julgadora na sessão de defesa do trabalho, manifestando-me plenamente favorável ao seu encaminhamento e publicação no Portal Digital de Teses da USP.

São Paulo,_25__11/_2020

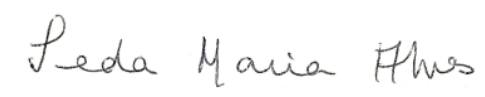




\section{DEDICATÓRIA}

Ao meu filho Gabriel, minha mãe, meus irmãos, sobrinhos e amigos! Dedico também este trabalho ao meu pai e ao meu marido (in memorian), que partiram para o plano espiritual no ano de 2019. Agradeço-lhes por todo o apoio nesta trajetória. 


\section{AGRADECIMENTOS}

À professora-doutora Ieda Maria Alves, que muito me ensinou nos anos de nossa convivência, contribuindo para meu crescimento científico e intelectual desde o mestrado, e também pela estimada amizade.

À minha família, que esteve na torcida para que este projeto e sonho fosse realizado.

Aos meus amigos, pelo apoio e carinho ao longo dos momentos mais prazerosos e difíceis da minha vida.

Aos professores-doutores Mariângela de Araújo e Odair Luiz Nadin da Silva, pelas valiosas contribuições na banca de qualificação.

Aos professores-doutores Adriano Henrique Rebelo Biava, da Universidade de São Paulo (FEA-USP), Alberto Ajzental (Fundação Getúlio Vargas) e Ladislau Dowbor (Pontifícia Universidade Católica), pelas entrevistas concedidas sobre discussões teóricas na área de Economia.

Ao programador e colega doutor José Lopes Moreira Filho, pelas consultas e assistência sobre Linguística de corpus e processamento de dados.

Ao professor-doutor e amigo Yuri Amorim Caribé, da UFPE, que concedeu também entrevista sobre interface entre tradução e terminologia.

A todos os colegas integrantes e ex-integrantes dos grupos de pesquisa liderados pela minha orientadora professora-doutora Ieda Maria Alves, com especial apreço a Luciana Pissolato de Oliveira, que contribuiu com o envio de alguns textos sobre metáfora.

A todos os membros do NUPPLE da PUC de São Paulo, grupo de pesquisa do qual também faço parte, em especial a Professora-Doutora Regina Célia Pagliuchi da Silveira. Aos meus alunos, ex-alunos e colegas da Universidade Nove de Julho, que me acompanharam durante toda esta trajetória, e, ao CIC do Imigrante da Barra Funda.

Por último, a todos os professores e funcionários da Faculdade de Letras da FFLCH-USP que contribuíram, de uma maneira ou de outra, para a realização deste estudo. 
O homem é um ser que se criou a si próprio ao criar uma linguagem. Pela palavra, o homem é uma metáfora de si próprio.

Octavio Paz 


\section{RESUMO}

Este trabalho, que se circunscreve no âmbito da Terminologia, visa analisar as metáforas conceptuais da Economia, nossa área-objeto de pesquisa acadêmica. Essa investigação justifica-se devido ao fato de a linguagem científica desse ramo ser um recurso prolífico nas conceptualizações e denominações dessa área de conhecimento, uma vez que as metáforas da Economia possibilitam a apreensão de um conhecimento "complexo" junto às analogias que se referem a algo já conhecido em nosso cotidiano. Para a realização desta pesquisa, constituímos um corpus composto por gêneros acadêmicos que circulam entre especialistas e em vias de formação na área econômica, tais como: artigos científicos, dissertações de mestrado e teses de doutoramento disponíveis em formato eletrônico pelos sites da USP e da Unicamp. Observamos que o grau de especialização dos textos estudados determinou a natureza e a função das metáforas terminológicas desse campo de estudo: expor informações a fim de transmitir e de construir saberes, colaborando por sua vez no processo de conceptualização de um referente - devido a relações de semelhanças estabelecidas entre o conceito especializado e um conceito familiar. Os termos prospectados e analisados, sobretudo sob o viés da Linguística Cognitiva, revelam que os conceitos apresentados por esse tipo de linguagem são projetados pelos domínios-fontes de outros domínios de conhecimento como a Física ou a Biologia; além de se apoiarem em domínios do cotidiano, o que funda a estrutura do pensamento científico. Por último, consideramos também que as metáforas da Economia do ponto de vista de seus aspectos comunicativos, semânticos e cognitivos apresentam uma função pedagógica e sobremaneira heurística, uma vez que os mapeamentos de seus conjuntos de correspondências conceituais entre os elementos de um domínio-fonte para o domínio-alvo revelam a compreensão de conceitos que didatizam seus conhecimentos em um processo de interlocução de ensino e aprendizagem no nível da especialização.

Palavras-chave: Terminologia; Metáfora; Economia; Ciência; Cognição. 


\begin{abstract}
The present work, within the context of Terminology, aims to analyze metaphorical concepts used in Economics, the object-field of our research. Such investigation is justified due to the fact that the scientific language of this field is a prolific resource in the conceptualizations and denominations of this area of knowledge, since the metaphors of economics make it possible to grasp a knowledge "complex" along with analogies that refer to something already known in our daily lives. For the accomplishment of this research, we constituted a corpus composed by academic genres which circulate among specialists and in formation courses in the economics area, such as: scientific articles, masters dissertations and doctoral theses available in electronic format through the USP and Unicamp websites. We observe that the degree of specialization of the studied texts determined the nature and function of the terminological metaphors of this field of study: to expose information in order to transmit and construct knowledge, collaborating in the process of conceptualizing a referent - due to relations of similarities established between the specialized concept and a familiar concept. The terms prospected and analyzed under the bias of Cognitive Linguistics reveal that the concepts presented by this type of language are projected by the source domains of other domains of knowledge such as physics, biology; besides relying on everyday domains, which founds the structure of scientific thought. Finally, we also consider that the metaphors of economics from the point of view of their communicative, semantic and cognitive aspects have a pedagogical and highly heuristic function, since the mapping of their sets of conceptual correspondences between the elements of a source domain for the target domain reveals the understanding of concepts that didacticize their knowledge in a process of interlocution of teaching and learning at the specialization level.
\end{abstract}

Keywords: Terminology; Metaphor; Economy; Science; Cognition 


\section{LISTA DE ABREVIATURAS, SIGLAS E SÍMBOLOS}

Adj $+\mathrm{S}$ Met + Adj - adjetivo + substantivo metafórico + adjetivo

Adj Met - adjetivo metafórico)

BNC - British National Corpus

IDE - Integrated Development Environment

ICMs ou m-ICM - Modelos Cognitivos Metafóricos

NLTK - Natural Language Toolkit

p.ana - por analogia

p.metf. - por metáfora

$\mathrm{PR}$ - ponto de referência

$\mathrm{S}$ Met + Adj - substantivo metafórico + adjetivo

S Met + SP - substantivo metafórico + sintagma preposicional

$\mathrm{S} \mathrm{Met}+\mathrm{SP}+\mathrm{Adj}-$ substantivo metafórico + sintagma preposicional + adjetivo

S + SP Met - substantivo + sintagma preposicional metafórico

S Met + SP Met + Adj - substantivo metafórico + sintagma preposicional metafórico + adjetivo

S Met + Sigla - substantivo metafórico + sigla

S Met + SP Met - substantivo metafórico + sintagma preposicional metafórico

$\mathrm{S}$ Met + Estrangeirismo - substantivo metafórico + estrangeirismo

S Met + SP [estrangeirismo] - substantivo metafórico + sintagma preposicional seguido de estrangeirismo

TCT - Teoria Comunicativa da Terminologia

TGT - Teoria Geral da Terminologia

TMC - Teoria da Metáfora Conceptual

TIC - Teoria da Integração Conceptual

UT - Unidade Terminológica

$\mathrm{ZA}$ - zona ativa 


\section{LISTA DE FIGURAS, GRÁFICOS E TABELAS}

Figura 1 - Etimologia da Economia................................................................ 15

Figura 2 - Organograma da Economia........................................................... 17

Figura 3 - Quadro econômico segundo François Quesnay................................. 19

Figura 4 - Modelo proposto por Fauconnier e Turner....................................... 41

Figura 5 - Shell script para automatizar a etiquetagem dos arquivos do

corpus.

Figura 6 - Shell script para automatizar a etiquetagem dos arquivos do corpus

Figura 7 - Exemplo de frase etiquetada em um dos arquivos do corpus.......... 67

Figura 8 - Esquema de processamento para criação de tabela de filtragem... $\quad 70$

Figura 9 - As 25 primeiras palavras-chave do corpus de estudo....................... 74

Figura 10 - Exemplos de termos metafóricos encontrados em outras

pesquisas............................................................................................................... $\quad 75$

Figura 11 - Dados importados para a planilha do Microsoft Excel.................. 76

Figura 12 - Exemplo de planilha para análise de bigramas................................. 79

Figura 13 - Demonstração da planilha de unigramas........................................ 80

Figura 14 - Demonstração da planilha de bigramas.............................................. 81

Figura 15 - Demonstração da planilha de trigramas.......................................... 81

Figura 16 - Demonstração da planilha de quadrigramas................................... 82

Figura 17 - Exemplo de interface para gerar linhas de concordância............... 83

Figura 18 - Exemplo de linha de concordância com contexto ampliado.......... 84

Figura 19 - Busca de termo em arquivo original do corpus............................... 85

Figura 20 - Planilha de termos da Economia...................................................... 87

Gráfico 1 - Representação dos resultados da Tabela 1......................................... 126

Gráfico 2 - Representação dos resultados da Tabela 2 ..................................... 133

Gráfico 3 - Representação dos resultados da Tabela 3........................................... 141

Gráfico 4 - Representação dos resultados da Tabela 4...................................... 158

Gráfico 5 - Resultado geral................................................................................... 160

Tabela 1 - Domínio da Física............................................................................. 94

Tabela 2 - Domínio da Biologia.................................................................................. 96

Tabela 3 - Metáforas Orientacionais.......................................................................... 99

Tabela 4 - Outros Domínios................................................................................... 100 


\section{SUMÁRIO}

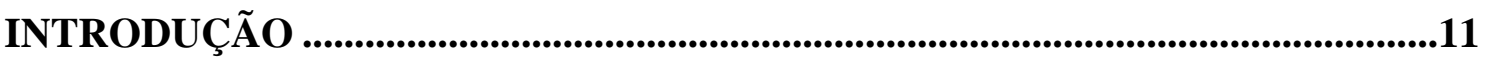

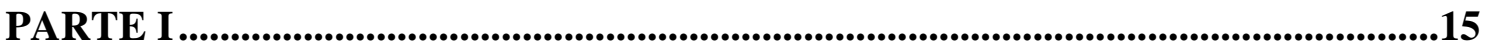

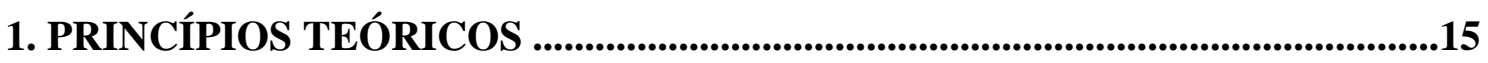

1.1 A Economia como ciência .................................................................................. 15

1.2 Conceituação e relato sobre suas principais escolas......................................... 15

1.3 As escolas econômicas e seus protagonistas ............................................................ 18

2. O TEXTO NOS ESTUDOS TERMINOLÓGICOS...............................................24

2.1 Os gêneros científicos do corpus analisado............................................................ 24

3. OS ESTUDOS SOBRE A METÁFORA …...............................................32

3.1. Breve apresentação da metáfora nos estudos tradicionais ................................ 32

3.2. Tendências atuais sobre o estudo da metáfora .................................................. 33

3.2.1 A Teoria da Metáfora Conceptual (TMC) ................................................... 37

3.2.2 A Teoria da Integração Conceptual (TIC) ................................................... 40

3.3 Teoria Sociocognitiva da Terminologia (TST)...................................................... 43

3.4 Metaforização e Terminologia................................................................................. 47

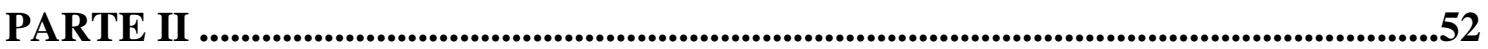

4. METODOLOGIA E PROCEDIMENTOS METODOLÓGICOS DA PESQUISA

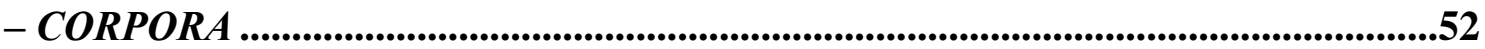

4.1 Constituição dos corpora: compilação e tratamento …………………………..... 52

4.2 Questões metodológicas na análise de metáforas ............................................... 54

4.2.1 Identificação de metáforas em corpus........................................................... 54

4.3 Características dos corpora ............................................................................ 56

4.4 Constituição dos corpora ...................................................................................59

4.5 Coleta do corpus...................................................................................................... 62

4.6 O processamento dos corpora ............................................................................... 64

4.6.1 Preparação dos textos para a formação do corpus de estudo.................... 64

4.6.2 Etiquetagem do corpus de estudo................................................................... 65

4.6.3 Criação de tabela de unigramas com filtros para manipulação de dados

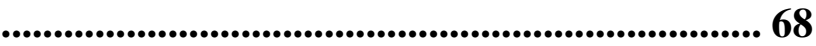

4.6.4 Lista de frequência das palavras do corpus ................................................. 70

4.6.5 Dicionário de palavras e etiquetas mais frequentes .................................... 71

4.6.6 Dicionário de palavras e lemas mais frequentes .......................................... 71

4.6.7 Lista de frequência das palavras em arquivos do corpus............................ 71

4.6.8 Lista de palavras inglesas ................................................................................. 72

4.6.9 Lista de palavras-chave do corpus de estudo .................................................. 73 
4.6.10 Lista de termos metafóricos encontrados em outras pesquisas

4.6.11 Combinação dos dados em uma única tabela de unigramas para filtragem 75

4.6.12 Aplicação de filtros na tabela de unigramas para redução de dados para análise 76

4.6.13 Procedimento de seleção de candidatos a termos em corpus especializado - referência 77

4.6.14 Criação de listas de bigramas, trigramas e quadrigramas .................... 78

4.6.15 Seleção de candidatos pelo pesquisador .................................................... 79

4.7 Criação de site para armazenamento de dados para busca.............................. 82

4.8 Procedimentos de análise dos candidatos a termos metafóricos da Economia Procedimentos de análise dos candidatos a termos metafóricos da Economian 85

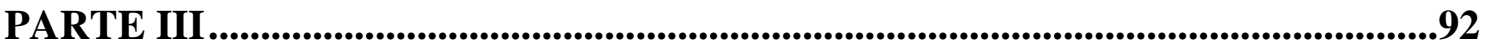

5. ANÁLISE DOS DADOS - TIPOLOGIA METAFÓRICA ....................................92

5.1 Os domínios das metáforas da Economia.....................................................92

6. ANÁLISE DAS METÁFORAS CONCEITUAIS DA ECONOMIA ....................106

6.1 A Física como campo de conhecimento ............................................................. 109

6.2 A Biologia como campo de conhecimento ...................................................... 110

6.2.1 A influência da Economia na Biologia ..................................................... 111

6.3. Análise dos traços conceptuais da Economia e seus respectivos domíniosfonte

7. BREVE CONSIDERAÇÃO SOBRE AS CARACTERÍSTICAS MORFOLÓGICAS DAS METÁFORAS DA ECONOMIA .................................... 161

7.1. Os decalques da Economia .............................................................................. 168

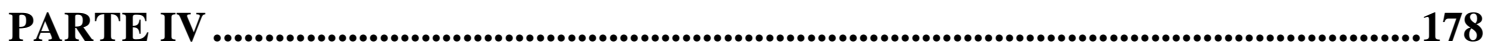

8. CONSIDERAÇÕES FINAIS...........................................................................178

8.1. O processamento das metáforas e a sua função nos corpora especializados da

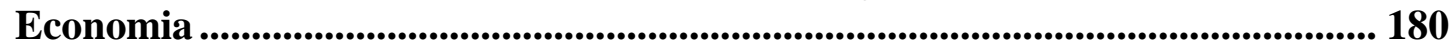

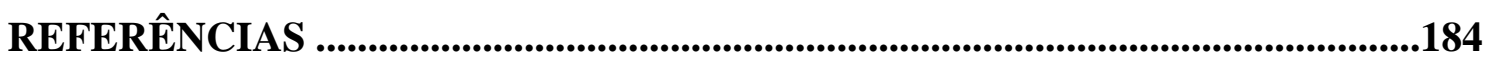




\title{
INTRODUÇÃO
}

\author{
Uma lata existe para conter algo \\ Mas quando o poeta diz: "Lata" \\ Pode estar querendo dizer o incontível \\ Uma meta existe para ser um alvo \\ Mas quando o poeta diz "Meta" \\ Pode estar querendo dizer o inatingível \\ Por isso, não se meta a exigir do poeta \\ Que determine o conteúdo em sua lata \\ Na lata do poeta tudo nada cabe \\ Pois ao poeta cabe fazer \\ Com que na lata venha caber \\ O incabível \\ Deixe a meta do poeta, não discuta \\ Deixe a sua meta fora da disputa \\ Meta dentro e fora, lata absoluta \\ Deixe-a simplesmente metáfora
}

(Gilberto Gil - Um banda um, 1982)

\section{A metáfora}

Sabemos que existe uma longa tradição do estudo da metáfora do ponto de vista retórico e estilístico, que normalmente a elevam ao plano de figura de estilo - assunto tratado por filósofos, pesquisadores e até mesmo por poetas e compositores, como demonstra a letra de música de Gilberto Gil, um dos maiores musicistas da música popular brasileira, transcrita acima. No entanto, na literatura atualizada sobre o assunto, a metáfora alça novos voos e ganha novo status de interpretação, indo além das concepções até então presentes sobre esse tema. Ainda no século XX, ela ganha fôlego sobretudo com as contribuições teóricas realizadas por George Lakoff e Mark Johnson (2002 [1980]), autores que afirmam que a metáfora trata de um processo cognitivo central e onipresente em nossas vidas, aprimorando dessa forma a defesa já apresentada em 1936 pelo pensador inglês Ivor Armostrong Richards (1893 - 1979) ao revisar as teorias tradicionais sobre esse processo, conformando as metáforas a um princípio orientador do pensamento associado a elas.

Tal ruptura proporcionou a possibilidade de realizarmos pesquisas sobre a metáfora que vão além da concepção de que ela funciona apenas como um recurso 
argumentativo que procura estabelecer semelhanças entre "objetos" díspares; ao afirmarmos que a metáfora também é cognição, criam-se novas possibilidades desse tipo de estudo de ordem teórica e metodológica em campos do conhecimento como o da linguagem científica, por exemplo.

Em nosso tipo de estudo, que envolve o léxico especializado, a metáfora conta com uma tradição nos estudos linguísticos, passando a ganhar prestígio nas pesquisas atuais. Fruto do fenômeno da variação denominativa/conceptual, o termo pode ser caracterizado como unidade linguística, comunicativa e cognitiva (CABRÉ, 1999, 2002), variando do ponto de vista semântico e formal no plano comunicativo pelas necessidades de adequação do discurso à situação comunicativa, e também aos aspectos relacionados à cognição, propugnado por múltiplos processos de conceptualização e de expressão do conhecimento especializado.

Como uma forma de contribuição em relação aos inúmeros estudos realizados no bojo das questões apresentadas acima, procuraremos, nesta tese, descrever e explicar como se processam as metáforas da terminologia da Economia nos planos conceptual, linguístico e comunicativo, uma vez que o processamento conceptual do mecanismo metafórico está associado, do ponto de vista linguístico, ao patamar da denominação (MINEIRO, 2004).

\section{Metáfora, ciência e cotidiano}

Em 1979 (p. 47-70), Booth afirmava que nunca havia ocorrido conferências sobre metáfora em nenhuma cultura antes de 1950. De acordo com o autor, após esse período as discussões sobre o assunto aumentaram em proporção estratosférica. Ele ainda "profetizava" que haveria mais metaforicistas do que metafísicos até a metade do século XXI.

Ainda que possa haver exagero sobre as considerações apresentadas acima, vivemos de forma intensa um período em que a metáfora tem ganhado destaque em pesquisas relacionadas a diversas áreas de conhecimento, tais como a linguística, a psicologia, a filosofia, a lexicografia, entre outras. Mas qual o motivo disso? Para Berber Sardinha (2007, p. 12), parte do interesse de investigação sobre a metáfora deve-se a ela ser entendida como uma espécie de extensão da própria condição humana e do uso que esta faz da linguagem. Nas últimas décadas - sobretudo com as novas perspectivas lançadas por Lakoff e Jonhson a partir dos anos 1980 -, a pesquisa sobre esse tema ganha 
impulso crescente, contribuindo para o destaque vertiginoso que ele tem recebido em estudos recentes.

Para Ulrike Schröder (2008, p. 39), a obra Metaphors We Live By, de George Lakoff e Mark Johnson (2002 [1980]), é decisiva para popularizar a ideia da metáfora cotidiana: "Nela, os autores concebem a metáfora em termos de um mapeamento entre dois domínios conceptuais, o domínio fonte e o domínio alvo". Nessa teoria, a FALA é fixada pela imagem de um CONTÂINER. A título de exemplo, levando-se em consideração o nosso corpus de estudo, a palavra "guerra" é utilizada para denominar alguns termos da Economia, a exemplo de guerra fiscal. Nesse tipo de termo, a Economia é fixada pela imagem da GUERRA. Para os defensores de um "realismo encarnado" (em inglês embodied realism), o centro dessa teoria está na metáfora conceptual corporificada, base para modelos cognitivos idealizados, responsáveis por gerar nossas estruturas de organização do conhecimento.

Iniciando-se essa nova perspectiva relacionada ao estudo da metáfora, passam a surgir inúmeras publicações de enfoque cognitivista. Essa abordagem possibilitou pesquisas em torno da metáfora talvez nunca antes imaginadas, tais como a própria possibilidade de se acreditar que a metáfora extrapola questões de estilo e de ornamentação da língua, impregnando toda a linguagem (até mesmo a científica e a terminológica), ocorrendo, inclusive, com mais frequência na escrita acadêmica (BERBER SARDINHA, 2015, p. 21).

Isso posto, dedicamo-nos então nesta tese a observar como se processa a metáfora na linguagem da Economia em corpora científicos, uma vez que esse recurso polissêmico contribui para os estudos terminológicos para a categorização de uma determinada área de conhecimento e para o desenvolvimento científico.

\section{Objetivos e organização do trabalho}

Em relação aos objetivos nucleares desta pesquisa, por meio da descrição e análise dos processos de conceptualização da terminologia da linguagem econômica em língua portuguesa (português brasileiro), pretendemos demonstrar a relevância e a produtividade das metáforas para a conformação de uma terminologia científica. Um dos desafios metodológicos da análise da metáfora refere-se à sua própria identificação e à explicitação das regularidades que delineiam o modo como ela é usada. Tendo-se em vista esse contexto, e partindo da ideia de que há padrões por detrás de seu uso, esta pesquisa tem 
por escopo demonstrar e analisar algumas dessas regularidades dos tipos de construção metafórica localizados a partir dos termos extraídos de corpora científicos que circulam no ambiente discursivo da Economia.

Como objetivos específicos, temos como propósito:

- analisar as metáforas terminológicas da Economia compiladas em um corpus que circula nesse tipo de ambiente discursivo acadêmico, sobretudo do ponto de vista cognitivo;

- caracterizar os gêneros textuais que fazem parte dos nossos corpora com o objetivo de compreender a natureza e as diferentes funções das metáforas em estudo;

- fazer um estudo de alguns de seus aspectos linguísticos, tais como os tipos de formação mais produtivos entre as metáforas coletadas: formações sintagmáticas e decalques;

- $\quad$ apresentar quais são os domínios-fonte mais frequentes e por que eles ocorrem, como os oriundos da Física e na Biologia, por exemplo. 


\section{PARTE I}

\section{PRINCÍPIOS TEÓRICOS}

\subsection{A Economia como ciência}

Neste capítulo, definiremos o significado de Economia do ponto de vista científico, suas áreas de estudo e setores mais significativos do pensamento econômico, apresentando uma breve discussão a respeito das escolas econômicas e de seus principais representantes.

\subsection{Conceituação e relato sobre suas principais escolas}

Antes de apresentarmos uma definição para o termo Economia, torna-se interessante apresentar a etimologia dessa palavra: de acordo com Cunha (1982), essa palavra compreende o conceito da administração da casa, uma vez que podemos apreender o seu sentido a partir da compreensão de que o prefixo eco representa a casa e nomia, normas e regras: "s. f'a arte de bem administrar uma casa ou um estabelecimento particular ou público1 XVI. Do lat. oeconomia, deriv. do gr. oikonomía [...]. Do lat. oeconomǐcus -a, deriv. do gr. oikonomikós [...] economizar 1813 [...] ecônomo XVII [...]”.

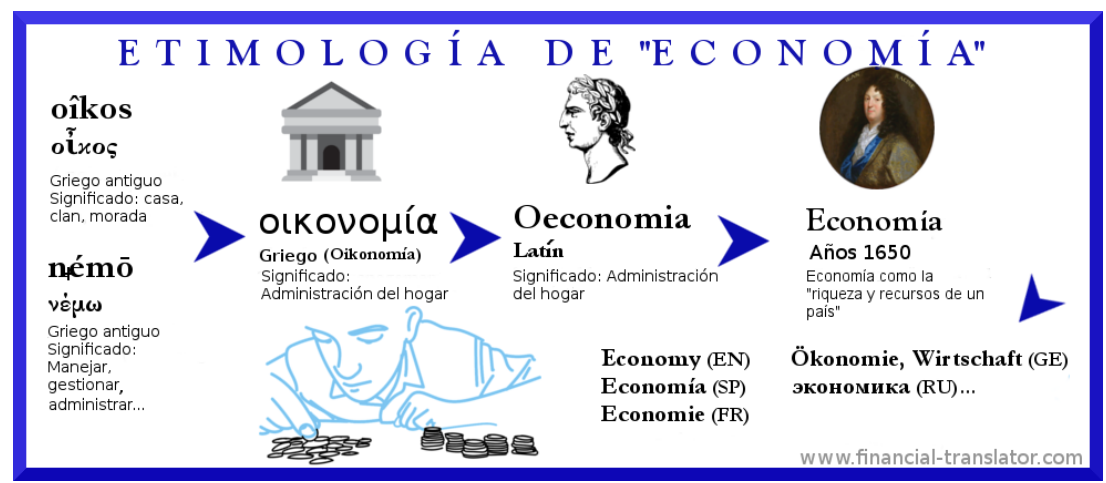

Figura 1 - Etimologia da Economia.

Fonte: <http://financial-translator.com/category/etimologia/>. Acesso em: 18 dez.2019.

Em entrevista realizada em 22 de maio de 2019, o professor-doutor de Economia da Pontifícia Universidade Católica de São Paulo Ladislau Dowbor afirma que Economia não é uma ciência, mas sim, um conjunto de ferramentas de apoio às ciências sociais. 
Contudo, essa definição não é a mesma compartilhada por outros autores consultados para a realização desta pesquisa, os quais afirmam ser ela uma ciência. Sendo assim, apresentaremos neste capítulo da tese as versões mais canônicas sobre a definição dessa área de conhecimento a fim de podermos abarcar alguns posicionamentos sobre a sua descrição e funcionamento.

Para Troster e Morcillo (1999, p. 5), a Economia pode ser definida como uma ciência que estuda a maneira pela qual os indivíduos e a sociedade fazem suas escolhas e tomam decisões a fim de que os recursos disponíveis, que são sempre escassos, "possam contribuir da melhor forma para satisfazer as necessidades individuais e coletivas da sociedade". Podemos afirmar que ela se ocupa em verificar de que forma os indivíduos empregam sua renda de forma a obter o maior aproveitamento possível. Para outros autores, tais como o professor de Marketing da Escola de Economia da Fundação Getulio Vargas Alberto Ajzental (2015, p. 133), a ciência econômica pode ainda ser definida por meio do conceito da riqueza, referindo-se àquilo que outra pessoa se dispõe a pagar em um determinado momento.

Essa ciência pode ser dividida em micro e macroeconomia: a primeira estuda o comportamento das unidades, tais como consumidores, as indústrias e empresas, e as suas inter-relações; a segunda ocupa-se em analisar o comportamento global do sistema econômico, "o produto total de uma economia, o emprego, o investimento, o nível geral de preço etc.” (TROSTER; MORCILLO, 1999, p. 6).

A seguir, apresentamos um organograma de seu funcionamento: ${ }^{1}$

\footnotetext{
${ }^{1}$ De acordo com Gomes (2015, p. 11), o mapa temático (organograma) da Economia a separa em duas grandes áreas: a macro e a microeconomia. A macroeconomia trata sobre a economia agregada, ocupandose da atividade produtiva em diversos setores, bem como com o resultado dessa produção. Ela leva ainda em consideração as relações entre agentes, que podem ser representadas por intermédio de um circuito econômico, deixando claro que, associado ao produto, está a despesa agregada, que corresponde majoritariamente ao consumo e investimento. A poupança é a outra face do consumo, agora do ponto de vista das decisões das famílias; quanto ao investimento, ele é principalmente composto por aquilo que se designa por formação bruta de capital fixo. No campo da microeconomia, são estudadas as relações de mercado, com ênfase nas respectivas forças, ou seja, a procura e a oferta. Nos mercados são transacionados bens, e a relação de mercado consubstancia-se na determinação de um preço de equilíbrio.
} 


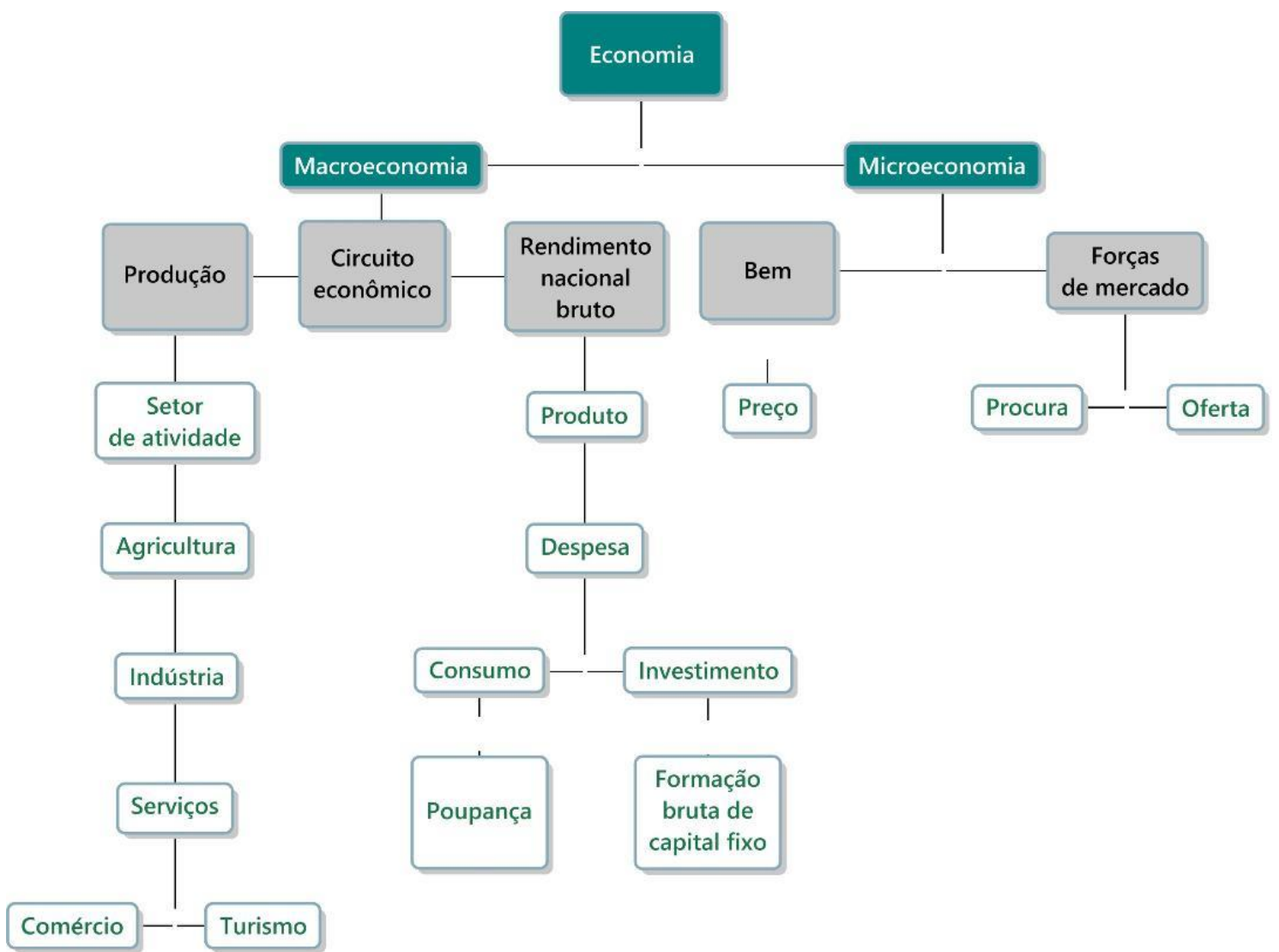

Figura 2 - Mapa temático da Economia.

O núcleo do problema econômico é a escassez; isso porque as necessidades humanas são "ilimitadas" e os recursos econômicos limitados. A escassez pode ser considerada como um conceito relativo, uma vez que existe o desejo de se adquirir uma quantidade de bens e de serviços maior do que os chamados "recursos naturais".

Os indivíduos satisfazem em primeiro lugar suas necessidades básicas, que são os primeiros bens desejados, primários, tais como alimentação, vestuário e saúde. Mais adiante, atende a outras necessidades mais sofisticadas, como, por exemplo, o turismo. Os bens econômicos apresentam uma tipologia, podendo ser classificados em bens de consumo - aqueles que satisfazem diretamente as necessidades humanas - e bens de capital - os utilizados na produção de outros bens -, além de poderem ser divididos em privados e públicos.

Quando não destinado à criação de bens, o trabalho visa a produção de serviços e pode estar relacionado com a distribuição de produtos ou com necessidades culturais (atividades exercidas por professores ou artistas, por exemplo).

Para a satisfação das necessidades humanas, produzem-se bens e serviços, e, para que isso ocorra, faz-se necessário o emprego de recursos denominados fatores de 
produção que podem ser divididos em terra (recursos naturais), capital (edificações, equipamentos - meios elaborados) e trabalho (faculdades físicas e intelectuais dos seres humanos que intervêm no processo produtivo).

Em uma análise crítica e histórica sobre os conceitos de micro e macroeconomia, o economista Paul Singer (1998, p. 36) afirma que as conclusões não poderiam ser mais contraditórias em relação à forma como essas duas forças que atuam de acordo com o pensamento econômico proposto por Keynes em 1936, momento em que os países capitalistas durante os anos 1930 foram afetados por uma longa crise econômica. Por um lado, condenava-se a intervenção governamental; por outro, não se valorizava esse tipo de interferência como condição que minimizasse a instabilidade cíclica da Economia.

Mais à frente, a partir da década de 1960, o intervencionismo defendido pela macroeconomia passa a ser questionado pelo chamado "neoliberalismo", o qual propõe a "taxa natural do desemprego". Em suma, Singer demonstra que, para definir esses dois conceitos, torna-se necessário entender quais são as forças que atuam contraditoriamente em cada um dos sistemas: na microeconomia, o liberalismo é intocável; na macroeconomia, o efeito da democracia política atua sobre o capitalismo.

Após essas observações, faremos a seguir uma apresentação resumida das principais escolas do pensamento econômico, descrevendo seus mais significativos representantes e as diferentes concepções defendidas por cada um.

\subsection{As escolas econômicas e seus protagonistas}

Médico de profissão, mas profundamente interessado em Economia, o pensador francês François Quesnay (1694 - 1774) é hoje visto como um dos precursores do pensamento econômico moderno. Líder do chamado "movimento fisiocrata" na França durante o conturbado reinado de Luís XV, para Quesnay a Economia era "regida por leis não intrínsecas, e somente a natureza podia gerar um excedente no processo produtivo, limitando o papel da indústria à transformação" (AJZENTAL, 2015, p. 140). Acreditando que a sociedade era governada por essa "lei natural", os fisiocratas afirmavam que, pelo fato de os governantes franceses não compreenderem essa lógica, estes teriam levado seu país a passar por sérios problemas econômicos.

A fim de ilustrar como se estruturam os processos de produção, circulação de moeda e distribuição de renda, Quesnay inventou um modelo conhecido por Tableau économique, o qual descrevia o recebimento das rendas, das transações e alocações dos 
produtos agrícolas e industriais, assim como a "perfeita" alocação de moeda para essas transações. Por meio desse modelo - ilustrado a seguir -, o autor apresentava um quadro de preços e níveis de produção que levariam a Economia ao equilíbrio:

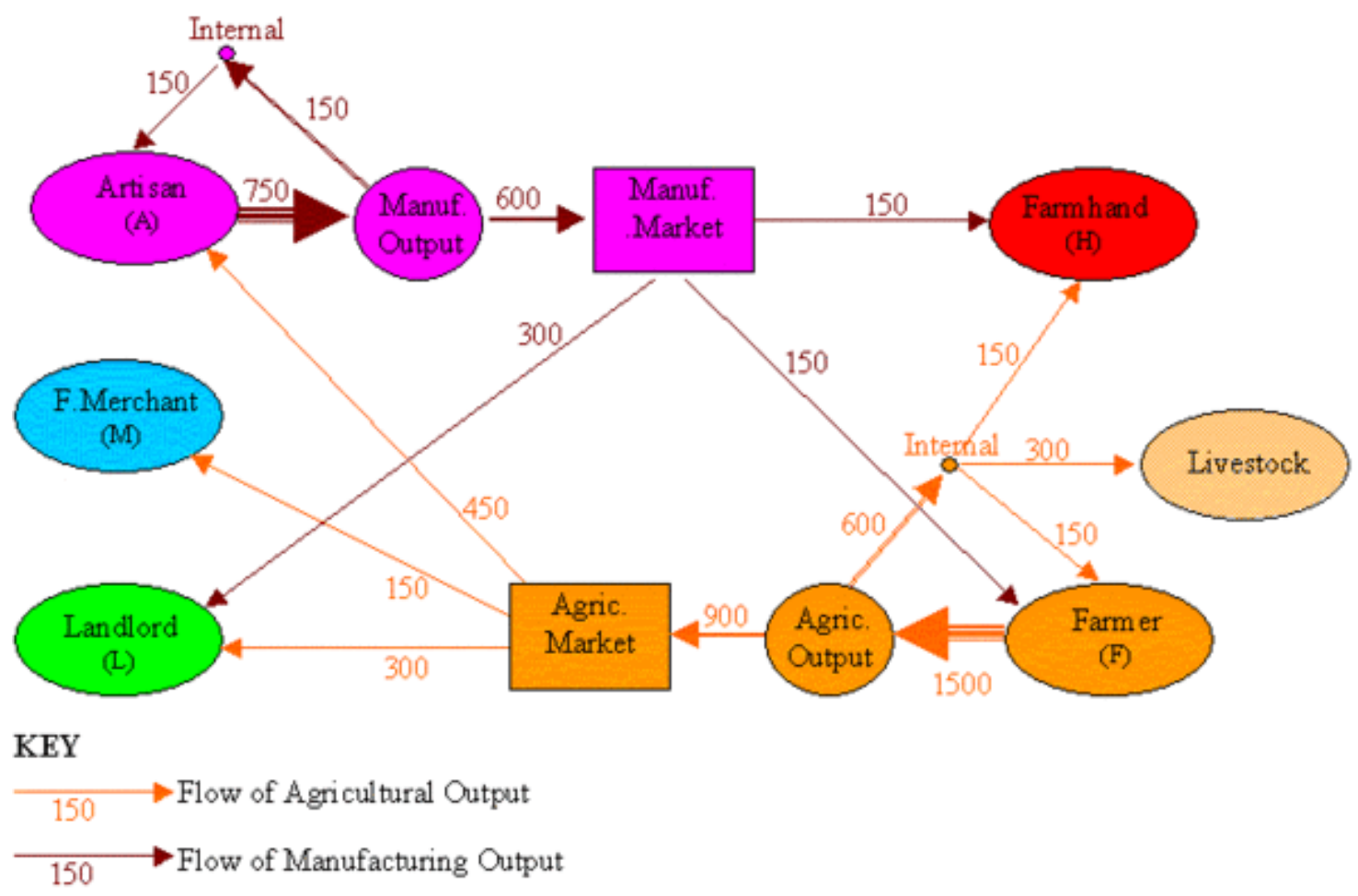

Figura 3 - Quadro econômico segundo François Quesnay. Fonte: 〈http://libertariens.chez-alice.fr/quesnay.htm>

Para descrever e defender sua teoria de como seria uma economia equilibrada, Quesnay fez uso de metáforas apoiadas na medicina, estabelecendo relações analógicas entre Economia e corpo. O especialista Ajzental explica que (2015, p. 141), segundo esse pensador francês: "uma economia equilibrada é uma economia saudável, assim como na medicina do século XVIII o corpo era assim considerado se seus 'humores' estivessem em equilíbrio".

Contemporâneo de Quesnay, o economista e estadista francês Anne Robert Jacques Turgot (1727 - 1781) seguiu adiante as teorias de seu compatriota, criando um conjunto de textos teóricos que hoje são vistos como um elo entre a fisiocracia e a escola britânica de economia clássica. De acordo com Ajzental (2015, p. 142), Turgot é considerado um dos pais do método econômico, autor da conhecida "lei de Say" (que, no século XX, viria a ser confrontada pelo economista inglês John Maynard Keynes [1883 -1946]). Essa lei estipulava a oferta como geradora da demanda, o que não possibilitaria 
uma permanente superprodução ou um subconsumo no livre mercado, uma vez que os preços poderiam se ajustar livremente.

Turgot era defensor do laissez-faire, doutrina que consiste na ideia de que o governo deve intervir o mínimo no funcionamento do mercado (contrário à forma de governar a Economia na França à época de Luís XV) ou nos desenvolvimentos da "revolução industrial" que estava em andamento.

Contudo, a teoria econômica do século XVIII não se restringiria aos pensadores franceses: um dos marcos mais importantes desse período iria acontecer na Grã-Bretanha com a publicação, em 1776, de A riqueza das nações, obra escrita pelo pensador escocês Adam Smith (1723 - 1790) na qual ele aborda os mecanismos que atuariam na criação e alocação da riqueza no mundo. De acordo com Smith, o valor econômico é criado quando as pessoas extraem matérias-primas do ambiente para, em seguida, por meio do trabalho, transformar esses materiais em algo útil; assim, o ponto de equilíbrio da Economia seria atingido naturalmente ao a deixarmos atuar "por conta própria": A "mão invisível" do mercado possibilita a alocação eficiente de recursos, mecanismo próprio das economias competitivas. Para ele, a tensão central na economia concentrava-se entre consumidores e produtores, sendo seu equilíbrio alcançado simplesmente por meio da oferta e da demanda.

Influenciada tantos pelos franceses quanto pelas ideias de Adam Smith, formouse na Inglaterra da segunda metade do século XVIII uma nova corrente de pensamento conhecida hoje como Utilitarismo, cujo principal representante nesse período foi o inglês Jeremy Bentham (1748 - 1832).

Para os utilitaristas, a Economia ia além das noções de valor econômico criadas quando as pessoas extraem matérias-primas do ambiente para, em seguida, transformálas em alguma coisa útil por meio do trabalho. De acordo com Ajzental, (2015, p. 143), para eles, a sociedade deveria organizar-se de modo que maximizasse "a utilidade, ou felicidade coletiva".

Bentham, que acreditava que a busca pelo "autointeresse" era uma atividade racional baseada em um cálculo que levava em consideração o prazer e a dor, teria defensores famosos no século XIX, como James Mill (1773 - 1836) e seu filho John Stuart Mill (1806 - 1873), ambos pensadores de renome que levariam suas ideias adiante. Em relação à intervenção do governo na Economia, por exemplo, estes acreditavam que ela deveria ocorrer de forma a maximizar os aspectos positivos e minimizar os negativos relacionados com o grau de liberdade do indivíduo. 
Contudo, até então esses economistas baseavam suas teorias apenas na formação os preços e nos custos de produção. A partir delas, a virada do século XIX viu surgir um novo grupo de pensadores que, influenciados pelos avanços científicos da época (principalmente na área da Física), começa a propor aprimoramentos à teoria clássica, alegando que a demanda era igualmente importante nesse processo. Esses economistas, chamados mais tarde de marginalistas, introduziram novidades matemáticas que levavam em consideração em seu cálculo a demanda, a oferta e a também a ideia de satisfação.

Dentre esse grupo, destacamos aqui o nome de León Walras (1834 - 1910), pensador francês que, de acordo com Ajzental (2015, p. 146), foi um revolucionário ao aplicar conceitos da Física matemática à Economia. Aplicando a metáfora da Física sobre o equilíbrio de forças em um sistema coeso às ideias de salários e preços - que deveriam ser flexíveis e ajustáveis -, ele propunha uma nova forma de determinar o equilíbrio entre a oferta e a demanda em um mercado.

Contudo, Walras não foi o único a estabelecer esses paralelos entre seus colegas "marginalistas". Na mesma época, o economista britânico William Stanley Jevons (1835 - 1882) também se valia de metáforas da Física ao afirmar que as diferenças nas utilidades individuais criavam um tipo de energia potencial ao comércio. Para Jevons, as ideias de valor estão para a nossa ciência como a energia está para a mecânica: “Assim como uma bola em uma tigela busca seu estado de energia mínima dentro dos limites das laterais, os seres humanos buscarão seu estado de felicidade máxima dentro das limitações de seus recursos finitos e negociarão para chegar lá” (AJZENTAL, 2015, p. 146).

Outro nome importante entre os marginalistas é o do ítalo-francês Vilfredo Pareto (1848 - 1923), cuja pesquisa se concentrava em testar se os mercados competitivos realmente maximizavam o bem-estar social e em quais circunstâncias isso ocorria. Pareto foi o criador do conceito conhecido como ótimo de Pareto, ponto máximo no qual ainda podem ser feitos negócios sem que ninguém saia prejudicado.

A partir desse conjunto de teorias, podemos dizer que o ponto central para os marginalistas era a ideia de que os participantes de uma economia de mercado poderiam fazer seus negócios de forma livre até atingirem um estágio no qual eles conseguissem a máxima satisfação possível em relação aos recursos disponíveis, mantendo assim o equilíbrio geral do sistema. 
O último quarto do século XIX viu também o aparecimento de uma nova corrente de pensamento apelidada mais tarde de "economia política neoclássica", que teve Alfred Marshall (1842 - 1924) como um dos seus grandes proponentes - de acordo com Ajzental (2015, p. 149), seu livro Princípios de economia (1890) chegou a ser uma das obras mais adotadas no ensino de Economia.

Duas contribuições feitas por Marshall merecem destaque. A primeira, e mais importante, foi a introdução de conceitos temporais de curto e longo prazo na teoria econômica, o que se considerou um marco nos debates da época sobre a determinação do valor. A segunda contribuição foi sua defesa de que o emprego do conceito de equilíbrio parcial se contrapusesse à teoria do equilíbrio geral.

Para além desses conceitos, esse pensador inglês também foi um dos principais influenciadores do chamado "darwinismo social", teoria que defende a ideia de divisão da sociedade em classes: aplicando essa analogia biológica à Economia, Marshall propunha um modelo que aplicava à sociedade o mesmo funcionamento da seleção natural na natureza.

Outro nome importante para a história da economia política neoclássica é o do inglês John Maynard Keynes (1883 - 1946). De acordo com Ajzental (2015, p. 150-5), esse pensador apresentava ideias inovadoras de caráter intervencionista, enfatizando as políticas fiscal e monetária, além de contribuições importantes no campo da teoria monetária e da análise do consumo.

Em 1950, as ideias de Keynes seriam ligadas pelo economista americano Paul Samuelson (1915 - 2009) às da teoria neoclássica. Criando a chamada "síntese neoclássica", Samuelson estabeleceu uma teoria do equilíbrio geral que consistia na ideia de que as pessoas são racionais em suas escolhas econômicas. Contudo, na década seguinte, a teoria de Keynes seria contestada pelo também americano Milton Friedman (1912 - 2006) em sua influente obra Capitalismo e liberdade (1962), na qual se defendia o liberalismo econômico.

No bojo das discussões sobre o liberalismo econômico, destaca-se a escola austríaca, inaugurada em 1871 por Carl Menger (1840 - 1921). Esse economista explicou a teoria da utilidade marginal, defendendo a ideia do teor subjetivo do valor econômico. Discípulo de Menger, o tcheco Eugen von Böhm-Bawerk (1851 - 1914) se envolveria mais tarde em uma "batalha" contra os marxistas sobre a exploração do capital, 
defendendo a ideia de que o "intervencionismo" era um malefício às teorias e práticas econômicas.

Essa escola ganhou destaque com uma quarta geração de economistas na figura de Friedrich August Von Hayek (1889 - 1992), economista e filósofo austríaco que acreditava que a Economia é um "complexo" e, por isso, não poderia ser planejada por uma instituição governamental.

Em meio a essas discussões, surge a chamada economia comportamental. Conforme Ajzental (2015, p. 161), repensando as ideias dos clássicos - como Adam Smith, por exemplo -, essa corrente representaria um novo campo que se fundamenta em termos de princípios psicológicos no que se refere à tomada de decisões. O economista israelense Daniel Kahneman (1934), um de seus defensores, recebe em 2002 o prêmio Nobel de Economia. Em seu discurso de agradecimento pelo prêmio, ele afirma que a Psicologia Cognitivista tem contribuído para a teoria econômica experimental no sentido de revelar que o homo economicus é determinado por interesse próprio, o que deve ser levado em consideração na teoria econômica.

Já a economia evolucionária, descrita por Ajzental (2015, p. 165-79) como um dos ramos da teoria econômica que desponta no último quarto do século XX, ocupa-se em estudar a organização econômica como um processo de "interações, competições, mudanças estruturais, escassez de recursos" que remetem ao campo da Biologia (o autor alerta, contudo, que essa linha de pensamento relacionando fenômenos sociais [economia] e biológicos já se apresentava a partir da segunda metade do século XIX).

Após realizar uma síntese sobre esse ramo da Economia e seus seguidores, desde Malthus até o "pensamento evolucionário moderno" presente nos textos de Richard Nelson e Sydney Winter na década de 1980, Ajzental afirma que essa tendência ganha grande força com as publicações das obras A lei da entropia e o processo econômico, de Nicholas Georgescu-Roegen (1971), Nova síntese, de Edward Wilson (1975), e An evolutionary theory of economic change, de Richard Nelson e Sydney Winter (1986), pois todos esses autores estabelecem comparações entre a concorrência no mundo biótico e no econômico.

Tais analogias estabelecidas entre a Biologia e a Física serão exploradas no próximo capítulo desta tese, com o intuito de se demonstrar de que forma os termos extraídos de nosso corpus de estudo revelam modos de compreensão da realidade econômica por meio de suas metáforas. 


\section{O TEXTO NOS ESTUDOS TERMINOLÓGICOS}

Neste capítulo, discutiremos questões relativas a tipologias e gêneros textuais baseando-nos na leitura de textos cujo enfoque é de caráter pragmático e sociodiscursivo, envolvendo também as teorias da Linguística Textual e da Socioterminologia. Buscaremos caracterizar os gêneros textuais científicos e analisar alguns de seus aspectos a partir de exemplos extraídos de textos acadêmicos da área da Economia.

\subsection{Os gêneros científicos do corpus analisado}

Há muito tempo já não se cogita estudar o léxico, seja ele especializado ou não, desvinculado do texto. Nesse contexto, a terminologia clássica prescritiva é suplantada pela descritiva, ganhando força nas linguagens especializadas o papel da textualidade e da discursividade, uma vez que nessa área de estudo há interesse em se estudar as estruturas e tipologias dos textos realizadas nas comunicações especializadas.

Os termos são identificados, definidos e estudados para as novas teorias de Terminologia (Teoria Sociocognitiva da Terminologia e Teoria Comunicativa da Terminologia, por exemplo) de acordo com "efeitos de todos os mecanismos sintagmáticos e pragmáticos das cadeias discursivas que dão suporte à comunicação especializada" (KRIEGER; FINATO, 2016, p. 106-7).

O vocábulo adquire o estatuto de termo em razão do cenário comunicativo no qual ele se inscreve, cujos discursos podem ser o político, o jurídico, o didático e o econômico, por exemplo. A concretização dessas unidades ocorre em textos cujas tipologias são distintas. O grau de densidade das informações prestadas pelos termos é diferente de acordo com os gêneros textuais e suas tipologias, enquanto a relação entre léxico e o grau de especialização dos textos é proporcional: "quanto maior o conteúdo conceptual veiculado pelo texto, maior a sua especialização" (OLIVEIRA, 2011, p. 86).

Para compreendermos as diferenças entre tipologias textuais e gêneros - mais especificamente, os gêneros que circulam no ambiente discursivo das ciências -, faremos referências às teorias que envolvem a Linguística Textual, a Pragmática e a Socioterminologia.

De acordo com Marcuschi (2000, p. 18), tipo textual é um construto teórico que abarca geralmente de cinco a dez categorias, tais como narração, argumentação, exposição e injunção, cujos agrupamentos são feitos quanto a sua natureza linguística e 
formal. Os tipos textuais são estratégias para organizar os gêneros, não havendo uma tipologia textual única.

Os gêneros textuais são as realizações linguísticas concretas dos tipos textuais cumprindo suas funções sociocomunicativas. A nomeação dos gêneros abrange um conjunto aberto de designações determinadas pelo canal, estilo, conteúdo, composição e função - por exemplo: telefonema, sermão, romance, novela, entre outros. Assim, as distinções do tipo textual são linguísticas e estruturais, ao passo que as do gênero são funcionais e pragmáticas (MARCUSCHI, 2002, p. 23).

Feitas essas considerações, trataremos de definir e apresentar algumas considerações sobre os gêneros que circulam no ambiente discursivo acadêmico, uma vez que os termos metafóricos de nossa pesquisa foram extraídos de gêneros textuais científicos (artigo, dissertação e tese), denominados como textos especializados, cujas definições baseiam-se nos seguintes fatores (CIAPUSCIO, 2008, p. 31-2):

- são produtos verbais de situações comunicativas específicas definidas pelos usuários dos textos com suas temáticas e finalidades;

- os textos especializados referem-se a temáticas próprias de um domínio de especialidade e respondem a convenções e tradições retóricas específicas;

- os fatores funcionais, situacionais e temáticos fazem correlação com a forma linguística tanto no nível da sintaxe como do léxico (no nível da sintaxe, são combinações obviamente da linguagem geral com regularidades e frequências específicas determinadas pelo registro e a classe do texto; em relação ao léxico, a presença relativa de terminologias é um sinal próprio e evidente de registro especial);

- os textos de especialidade se realizam em tipos de textos específicos nos discursos de uma determinada área de conhecimento (artigos científicos, artigos de divulgação científica, entre outros).

Ciapuscio (2008, p. 30) também afirma que há graus de especialidade dos textos dispostos em um eixo vertical (o nível horizontal refere-se à temática do texto) ordenando-se em dois polos: $<<+$ especializados $>>$ versus $<<-$ especializados $>$, eixo que se refere especialmente aos seus usuários e ao suporte; no nível tipológico, ele referese à situação. De acordo com a mesma autora (2008, p. 35), os mais especializados e 
menos especializados são, em escala de mais para menos, respectivamente: manual técnico, artigo de semidivulgação, enciclopédia e imprensa escrita.

Os tipos textuais se diferenciam por questões temáticas e situacionais. No nível da situação comunicativa, usuários influenciam a quantidade e a qualidade das informações que se transmitem, apreciam-se diferenças importantes segundo os destinatários. No caso do petróleo, por exemplo, em relação ao usuário semiespecialista, no manual técnico e na enciclopédia, ele é tratado como objeto da natureza. Em textos mais especializados, ele é compreendido do ponto de vista de suas propriedades. Nos artigos de semidivulgação e na mídia impressa, na perspectiva do meio ambiente, o petróleo é percebido como objeto contaminante.

Classificar os gêneros textuais é uma tarefa difícil, pois nem sempre seus limites são tão claros; muitas vezes, difusos. A fim de estabelecer demarcações entre um ou outro gênero textual científico, o mais interessante é observar quais são os aspectos linguísticos que permitem afirmar se o grau do texto é mais ou menos especializado. Ciapuscio (2008, cap. 4, p. 4) afirma que as contribuições mais interessantes para a tipologização dos textos especializados vêm da escola funcionalista. Essa corrente preconiza que a língua dispõe de recursos linguísticos que os falantes, levando-se em conta suas intenções, ambiente discursivo e situação, selecionam a variante linguística adequada. Na linguagem científica, estas seriam, conforme Gläser ${ }^{2}$ (1982, s.p. apud Ciapuscio, 2008, p. 5), cinco estilos científicos:

- o estilo acadêmico-científico e tecnológico (o grau mais alto de abstração que se realiza, por exemplo, em monografias, artigos científicos e comunicação apresentadas em congressos);

- o estilo de divulgação científica (estilo de grau de abstração médio dirigido a um público amplo, que ocorre em revistas de divulgação por exemplo);

- o estilo diretivo (estilo de texto que indica como realizar ações tais como leis, contratos etc.);

- o estilo prático da comunicação cotidiana (estilo das comunicações que ocorrem no cotidiano, nas quais são empregados termos técnicos e científicos não codificados, mas em parte estabelecidos pela convenção).

\footnotetext{
${ }^{2}$ GLÄSER, R. The Problem of Style Classification in LSF (ESP). In: En Høedt, J.; Lundquist, L.; Picht, H.; Qvistgaard, J. (ed.). Proceedings of the 3rd. European Syposium on LSP. Copenhagen: Erhversøkonomisk Folarg, 1982.
} 
Loffler-Laurian $^{3}$ (1983, s.p., apud Ciapuscio, 2008, p. 9) pensou em outra tipologia do discurso científico que vale a pena também ser mencionada, uma vez que ela representa alguns tipos de discursos a serem estudados nesta tese:

- discurso científico especializado;

- discurso de semidivulgação científica;

- discurso de divulgação científica;

- discurso científico-pedagógico;

- discurso do tipo memória, tese;

- discurso científico oficial.

Os gêneros que fazem parte de nosso corpus de estudo pertencem ao nível mais alto de especialização, cujo patamar de abstração é o mais alto por circularem no meio acadêmico. Contudo, devemos atentar para o fato de que, por serem textos eletrônicos, ou seja, por circularem na web, nem sempre eles são restritos a um público especializado, ainda que tenham sido escritos com o intuito específico de apresentar resultados de pesquisa a seus pares. ${ }^{4}$

Para Ciapuscio (2008, p. 98), os textos podem ser analisados levando-se em consideração os seguintes níveis: funcional, situacional, semântico e formal-gramatical. Esses diferentes níveis mantêm relações complementares que permitem descrever o texto tanto do ponto de vista de sua microestrutura (relações entre sintaxe, semântica e léxico) como de sua macroestrutura (referência a estilos e gêneros textuais).

Segundo Adorne (2012, p. 46), os níveis acima citados ligam-se às funções textuais caracterizadoras dos gêneros de textos. O nível situacional diz respeito a fatores circunstanciais de tempo e lugar de uma dada produção textual e às esferas sociais dessas realizações discursivas. O nível semântico refere-se ao núcleo conceitual do texto associado à atitude do produtor em relação à temática escolhida. Por último, o nível formal-gramatical reúne os recursos linguísticos associados a gêneros específicos, de forma que o estilo científico é caracterizado por modelos de formulação, condicionadores

\footnotetext{
${ }^{3}$ LOFFLER-LAURIAN, A. M. Vulgarisation scientifique: formulation, reformulation, traduction. Langue Française, v. 64, p. 109-25, 1983.

${ }^{4}$ Os gêneros acadêmicos que fazem parte de nosso corpus para a prospecção dos termos metafóricos, conforme já dissemos anteriormente, são o artigo acadêmico, a dissertação de mestrado e as teses de doutorado, os quais serão caracterizados no item 4.2 da Parte II (Procedimentos metodológicos - corpora) deste trabalho.
} 
de escolhas sintáticas (o uso de formas impessoais e da voz passiva para marcar distanciamento) e léxicas (a densidade e o tratamento terminológico são recursos lexicais essenciais para a determinação de seu estatuto especializado).

Levando-se em consideração os níveis acima mencionados, podemos considerálos, no bojo dos textos especializados da Economia (artigo acadêmico, dissertação de mestrado e tese de doutorado), resumidamente, da seguinte forma:

\section{a) nível funcional}

Os gêneros discursivos da Economia aqui tratados manifestam uma mesma função: expor informações a fim de transmitir e de construir saberes. Essa função estabelece relações com a intencionalidade do texto que incide sobre a informação veiculada - no caso, a de argumentar -, representando assim um fator central, uma vez que a informação é uma estratégia orientada para o convencimento acerca da propriedade dos conceitos desenvolvidos, ao mesmo tempo em que dados são disponibilizados. A seguir, entre aspas, transcrevemos um trecho extraído de um artigo científico do nosso corpus de estudo que demonstra esse tipo de propriedade: "Este trabalho mostra que as companhias brasileiras distribuem uma proporção pequena dos lucros em dividendos, apesar da legislação favorável o artigo aborda, [...] pretende-se fazer algumas considerações."

Também é possível verificar no exemplo acima a defesa de determinados pontos de vista apresentados pelo autor nas passagens a seguir sobre o tema do auxílio da mão de obra estrangeira na economia cafeeira:

Particularmente importante será a discussão da literatura relacionada com o fluxo e a inserção de trabalhadores, inclusive os profissionais e investidores, na economia cafeeira [...]. Contudo, esta tese revela, também, a importância dos estrangeiros residentes em Campinas antes do grande movimento imigratório iniciado em 1886. Suas profissões especializadas e seus investimentos contribuíram decisivamente para o crescimento econômico local e regional. ${ }^{6}$

\footnotetext{
${ }^{5}$ SILVA, G. da. J. C.; BRITO, R. D. “Testando as previsões de Trade-Off e Pecking Order sobre dividendos e dívida no Brasil”. Est. econ., São Paulo, v. 35, n. 1, p. 37-79, jan.-mar. 2005.

${ }^{6}$ ABRAHÃO, F. A. P. Padrões de riqueza e mobilidade social na economia cafeeira, 1870-1940. 2015, 235 f. Tese de doutorado apresentada à Faculdade de Filosofia, Letras e Ciências Humanas (FFLCH) da Universidade de São Paulo (USP).
} 


\section{b) nível situacional}

Em relação ao nível situacional, os interlocutores desse ambiente discursivo apresentam uma relação de simetria. A situação comunicativa parte de um especialista (professores universitários e pesquisadores da área) que se dirige a um interlocutor com as mesmas características de seu locutor (podendo ser também um especialista em via de formação ou mesmo um jornalista econômico, o qual transmitirá novidades científicas da área econômica a um grupo mais numeroso e heterogêneo). ${ }^{7}$

\section{c) nível semântico}

Os textos aqui analisados enfatizam aspectos temáticos diferentes. Há vários nódulos conceituais diferentes em Economia, tais como: evolução do pensamento econômico, princípios de economia, história econômica, contabilidade, teoria micro (mercados) e macroeconômica (oferta, demanda e crescimento), economia marxista, formação econômica do Brasil, estatística econômica, econometria, economia do setor público, economia do agronegócio, contabilidade social e ambiental, economia internacional, economia industrial, economia monetária, economia ambiental, vida

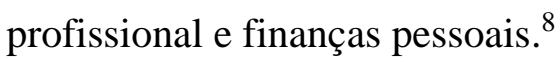

De acordo com Oliveira (2011, p. 85), regularmente, o texto especializado revela de forma explícita o conteúdo que se deseja transmitir. Para tanto, ele demonstra evidências "da verdade" dos fatos, levando o leitor a comprová-las. Sua postura oscila entre teoria (levar a conhecer um fato novo) e prática aplicada - demonstrar a utilidade da nova descoberta).

\section{d) nível formal-gramatical}

\footnotetext{
7 Os textos que compõem o corpus estão disponíveis em meio eletrônico. Portanto, não se trata aqui de uma circulação restrita, de forma que se torna problemático falar de uma comunicação restringida a um público especialista, como o faz Guimar Ciapuscio (2003).

8 Os temas em questão foram extraídos do texto "Formação do economista no Brasil contemporâneo", escrito por Fernando Nogueira da Costa e publicado na revista da Unicamp Texto para Discussão (Campinas, $\quad$ n. $279, \quad$ set. 2016). Disponível <www.eco.unicamp.br/docprod/downarq.php?id=3482\&tp=a>. Acesso em: 5 nov. 2018.
} 
Os textos do corpus em estudo revelam as características prototípicas dos seus gêneros textuais. Nesses textos, há normalmente um enunciador especialista que usa a terceira pessoa, de acordo com o exemplo entre parênteses marcado em itálico a seguir: "Este trabalho mostra que as companhias brasileiras distribuem uma proporção pequena dos lucros em dividendos [...]"; ou da $1^{\text {a }}$. pessoa do plural e verbos na voz passiva (destacados em itálico): "Nos casos de ocupações desconhecidas, adotaram-se os seguintes critérios: se o inventariado acumulou uma ou mais propriedades rurais produtivas, ele foi classificado como produtor rural"), ${ }^{9}$ procurando alcançar o efeito de sentido da objetividade, construído por meio do distanciamento e mesmo do apagamento do sujeito enunciador. Entretanto, devemos nos lembrar de que se trata também de textos com teor crítico. Essa característica se reflete no uso da primeira pessoa do plural (marcada no mesmo artigo em questão em itálico a seguir) que aproxima o enunciador do enunciatário pelo compartilhamento de experiências, e na presença de qualificativos (palavras que exprimem qualidade): "Nossas medidas de lucratividade, oportunidades de investimento e riscos são as mesmas de Fama e French".

As relações sistemáticas entre o nível do léxico e o grau de especialização dos textos é muito relevante para caracterizar um texto de especialidade, conforme já afirmado por nós anteriormente. No exemplo a seguir, observamos que os vocábulos metafóricos do tipo alavancagem e volatilidade ${ }^{10}$ chancelam o nível de especialização do gênero textual artigo acadêmico em destaque, uma vez que esses termos se referem a conceitos que no contexto discursivo da Economia significam a obtenção de lucros com o mínimo de esforço e oscilação das cotações de moedas no mercado de câmbio. $\mathrm{O}$ uso da sigla TP no exemplo a seguir (meta de longo prazo para a taxa de remuneração) garante também ao texto um "alto" nível de especialização no que se refere ao âmbito da Economia:

\footnotetext{
Ou seja, nesta segunda etapa, pela introdução de termos de interação, permitese que a meta de remuneração (TP) varie entre as empresas em função das oportunidades de investimento, lucratividade, <volatilidade>, <alavancagem> e investimento. (SILVA, G. da. J. C.; BRITO, R. D. "Testando as previsões de Trade-Off e Pecking Order sobre dividendos e dívida no Brasil”. Est. econ., São Paulo, v. 35, n. 1, p. 37-79, jan.-mar. 2005.)
}

\footnotetext{
${ }^{9}$ ABRAHÃO, F. A. P. Padrões de riqueza e mobilidade social na economia cafeeira, 1870-1940. 2015, 235 f. Tese de doutorado apresentada à Faculdade de Filosofia, Letras e Ciências Humanas (FFLCH) da Universidade de São Paulo (USP).

${ }^{10}$ Utilizaremos as aspas francesas simples $(<>)$, mas não duplas, nas citações dos termos em destaque extraídos do corpus com o intuito de não afetar a formatação de origem e também para não repetir o mesmo sinal usado durante a análise das unidades terminológicas no corpo do texto, que são as aspas altas (“").
} 
Os termos metafóricos em análise, obviamente, não podem ser tratados neste trabalho como recursos expressivos do ponto de vista linguístico. Devem sobretudo ser compreendidos e analisados em função de suas propriedades heurísticas, colaborando por sua vez no processo de conceptualização de um referente - devido a relações de semelhanças que se estabelecem entre o conceito especializado e um conceito familiar. As metáforas da terminologia são associadas a um termo e não ao seu entorno textual, não sendo, portanto, abertas à subjetividade de interpretações como em um texto literário (é o caso de "alavancagem" e de "volatilidade", metáforas apresentadas no contexto acima). Essas características estão de acordo com as do texto especializado, prezando pelo estilo objetivo e formal pelo qual se apresentam teorias e dados de pesquisa imprimindo ao texto densidade conceptual (OLIVEIRA, 2011, p. 88). 


\section{OS ESTUDOS SOBRE A METÁFORA}

Neste capítulo, apresentaremos de forma concisa os estudos tradicionais da metáfora a fim de acompanharmos a sua evolução histórica, culminando nas Teorias da Metáfora Conceptual (TMC) e da Integração Conceptual (TIC), bem como nos estudos da metáfora no âmbito da Teoria Sociocognitiva da Terminologia, que serão contempladas de acordo com as necessidades do nosso corpus de estudo.

\subsection{Breve apresentação da metáfora nos estudos tradicionais}

Os primeiros estudos sobre a metáfora remontam à Antiguidade. Aristóteles (2006, p. 182, apud Berber Sardinha, p. 20) ${ }^{11}$ compreendia que a metáfora substituía uma palavra de valor literal para uma de sentido figurado, ou seja, era definida como um tipo de transposição. Um de seus exemplos é "a velhice é a tarde da vida" em que a velhice é comparada ao final do dia, período antes do anoitecer. Ela pertencia ao âmbito dos estudos da Retórica, tinha valor estético e servia à ornamentação da linguagem.

Ainda na Antiguidade Clássica, Quintiliano concebia a metáfora como um recurso retórico com valor de translatio (transposição). Esse autor define a metáfora como um processo de comparação abreviada: "Há comparação quando se diz de um homem que, em certa ocasião, agiu como um leão; metáfora, quando digo do homem: é um leão" (Institutio Oratoriae, tr. fr. de Henri Bornecque, 1934, liv. VIII, 6, 4 e 8). ${ }^{12}$

Para Berber Sardinha (2007, p. 21), ao longo do tempo, a metáfora foi interpretada nos moldes clássicos da retórica como fator de "transposição" e de comparação abreviada, passando a ser desmembrada em muitas figuras de linguagem, cujas classificações intensificaram-se na Renascença, seguindo a tendência desse período de agrupar o mundo em categorias.

Ao longo dos dois séculos seguintes, a concepção de metáfora permaneceu basicamente inalterada, ganhando novos desenvolvimentos apenas no século XIX com os trabalhos do filólogo francês Michel Bréal (1832 - 1915) - criador do termo polissemia -, que passa a apresentá-la em uma perspectiva diacrônica. Bréal afirmava que a metáfora muda de forma instantânea o sentido das palavras, criando novos significados

\footnotetext{
${ }^{11}$ Aristóteles. Arte poética. São Paulo: Martin Claret, 2006.

${ }^{12}$ MOISÉS, M. Dicionário de termos literários. São Paulo: Cultrix, 1988.
} 
subitamente, de maneira que ela não permanece tal como em seu início. ${ }^{13}$ Logo, algumas metáforas não são compreendidas por nós porque não conhecemos a sua história. Do ponto de vista de seu processamento, esse autor também a compreende como uma relação de semelhança entre dois objetos.

Outro autor que deve ser lembrado nesse breve histórico sobre a evolução do conceito da metáfora é o linguista húngaro Stephen Ullmann (1914 - 1976), que concebia a metáfora (além de um processo de transferência e de comparação) como fator de imaginação e de expressividade, dividindo-a em quatro categorias, a saber:

- antropomórficas - originadas a partir da relação do homem com o próprio corpo;

- animais - aplicadas à esfera humana e a objetos adquirindo, muitas vezes, significações humorísticas, irônicas, pejorativas e grotescas;

- do concreto ao abstrato - tendências básicas da metáfora consistentes em traduzir experiências abstratas em termos concretos;

- metáforas sinestésicas - baseadas nas transposições de um sentido para outro, por exemplo, do ouvido para a vista, do tato para o ouvido (ULLMANN, 1964, p. 442).

Acreditamos que podemos encerrar essa revisão histórica sobre a metáfora com a concepção apresentada por Ullmann, pois ele é um dos últimos autores - a começar por Aristóteles - que concebe esse processo semântico apenas como um processo de comparação.

Antes da metade do século XX, novas tendências a respeito da metáfora começam a despontar. Nesse cenário, em 1936, Igor A. Richards revisa as teorias tradicionais sobre esse assunto e declara haver um princípio orientador do "pensamento" associado a elas, rompendo então com a visão tradicional da metáfora como fator de translatio e de comparação.

\subsection{Tendências atuais sobre o estudo da metáfora}

\footnotetext{
${ }^{13}$ Neste sentido, acreditamos que a metáfora muda o sentido das palavras, porém o termo metafórico sempre carrega algum sema do sentido do vocábulo que foi aplicado em outro contexto, por exemplo, em tigre asiático, sabemos que os semas de "força, valentia, ferocidade e poder" são preservados.
} 
Nos estudos linguísticos atuais mais relevantes ao tema desta pesquisa, podemos citar inicialmente os trabalhos do filósofo britânico-americano Max Black (1909 - 1988). Aprofundando noções já apresentadas por Richards em 1936, Black concebia a metáfora como fator de interação: sua teoria afirmava que o novo sentido da metáfora sobrevém da interação entre o tópico e o veículo, conforme pode ser ilustrado por meio do exemplo a seguir:

[...] para exemplificar, numa expressão como 'Julieta é o sol'. 'Julieta' é o tópico e 'sol', o veículo, ou termo metaforizado. [...] Segundo a teoria da interação, não haveria nenhuma similaridade preexistente entre Julieta e sol de onde pudéssemos retirar as informações necessárias para entender a metáfora: estamos comparando uma pessoa a uma parte do cosmo. Certamente podemos pensar literalmente no sol sem nunca incluir qualquer atributo relacionado a Julieta, até porque muitos de nós nem a conhecemos. Por outro lado, não há nada na definição de Julieta que nos diga que ela possa ser o sol, ou a lua ou qualquer outro corpo celeste.

Precisamos criar essa similaridade para dar sentido à expressão e fazemos isso criando interação entre Julieta e o sol. Nesse processo de interação, Julieta passa a receber propriedades relativas ao sol, ao mesmo tempo em que o sol passa a receber propriedades de Julieta. Criamos então mentalmente um sistema de relações onde não havia nenhuma, para podermos dar conta da metáfora. (BLACK, 1955 e 1962, s.p., apud Berber Sardinha, 2007, p. 29) ${ }^{14}$

A partir de 1970, começa a grande revolução em torno da percepção do que vem a ser metáfora, com o impulso das Ciências Cognitivas, mais especificamente, pelas pesquisas em Psicologia Cognitiva, que observavam o funcionamento das metáforas que vinham causando problemas às teorias da compreensão. De instrumento meramente linguístico, ela passa a ser vista como um elemento constitutivo de nosso pensamento, revelando de que forma experimentamos e categorizamos o mundo. Portanto, essa nova visão põe em crise o enfoque objetivista da metáfora, atribuindo-lhe um status epistemológico, rompendo com a tradição retórica iniciada por Aristóteles no século IV a.C. e mudando uma história de mais de dois milênios.

Nesse cenário, surge um trabalho que revolucionaria as teorias sobre a metáfora já existentes: Metáforas da vida cotidiana (1980), de George Lakoff e Mark Johnson. Nesse texto, a visão cognitiva da metáfora é apresentada de forma que ela possa revelar de que forma guiaria nossos pensamentos e ações de acordo com a nossa cultura. Essa concepção é decisiva para novas teorias sobre esse assunto, indo além das questões meramente linguísticas. Os autores analisaram diversas expressões linguísticas

\footnotetext{
${ }^{14}$ BLACK, M. Metaphor. Proceedings of the Aristotelian Society, v. 55, p. 273-94, 1955.
} 
metafóricas e chegaram à conclusão de que grande parte de nosso sistema conceptual está estruturado por meio de metáforas. Elas atuam na percepção de nossas experiências mais simples, permitindo que possamos compreender uma ideia em termos de outra.

De acordo com essa nova concepção, corpo e mente não são mais vistos como separados, passando o mundo a ser compreendido por meio de metáforas construídas com base em nossa experiência corporal. Esse aspecto fica evidente, por exemplo, nas metáforas orientacionais, como FELIZ É PARA CIMA e TRISTE É PARA BAIXO, manifestadas em enunciados como: "estou me sentindo para cima", "ele está para baixo hoje". Esse conceito metafórico apresenta uma base física: quando estamos felizes, ficamos com a postura ereta, e, quando estamos tristes, estamos com a postura caída.

Em Metáforas da vida cotidiana (2002 [1980], p. 49-86), além das metáforas orientacionais, os autores apresentam também metáforas estruturais e ontológicas. As estruturais referem-se aos casos em que um conceito é "estruturado" metaforicamente em termos de outro. A representação metafórica dos conceitos que estruturam nossas atividades cotidianas pode aparecer em situações nas quais, por exemplo, compreendemos o AMOR em termos de VIAGEM. A partir da experiência cultural de que amor é um deslocamento no tempo e espaço, encontraremos enunciados metafóricos do tipo "Estamos em uma encruzilhada" ou "Nosso relacionamento não vai a lugar nenhum". As ontológicas compreendem nossas experiências em termos de objetos e substâncias, permitindo-nos selecionar partes de nossa experiência e tratá-las como entidades discretas ou substâncias de uma espécie uniforme, criando a possibilidade de referirmo-nos a elas, categorizá-las, agrupá-las e quantificá-las - de forma que possamos assim raciocinar sobre elas.

Nessa perspectiva teórica, a linguagem teria um papel secundário. Porém, essa "secundarização" da linguagem em detrimento dos mapeamentos cognitivos foi contestada por alguns linguistas. Melo Moura (2005, p. 116) afirma, por exemplo, que a expressão linguística não pode ser considerada posterior à estrutura conceptual, pois língua e estrutura conceptual interagem de forma bidirecional, e fatores linguísticos e conceptuais são mutuamente dependentes no uso da metáfora. De acordo com Sinha e Jensen de López ${ }^{15}$ (2000, s.p. apud Schröder, 2008, p. 41), outro aspecto que não foi discutido por essa geração foi o contexto sociocultural e comunicativo do desenvolvimento cognitivo. A partir de experiências realizadas com crianças, esses

\footnotetext{
${ }^{15}$ SINHA, C.; JENSEN DE LÓPEZ, K. Language, culture and embodiment of spatial cognition. Cognitive linguistics, Nijmegen, v. 11, n. 11/2, p. 17-41, 2000.
} 
estudiosos demonstram que a aquisição de esquemas imagéticos ${ }^{16}$ não são necessariamente um resultado da experiência corporificada, podendo ser também uma consequência da interação social.

Para Schröder (2008, p. 42-52), há três linhas de pesquisa atuais sobre a metáfora:

1 - Teoria da Mesclagem em redes de integração (Gilles Fauconnier e Mark Turner): nesse tipo de abordagem teórica, a mesclagem preconiza que podemos integrar estruturas parciais de dois domínios separados em uma única estrutura, pois, para eles, conhecimentos linguísticos e não linguísticos se mesclam. Fauconnier e Turner aprimoraram seu modelo de mesclagem apresentando o termo "rede de integração" em que é possível criar exemplos novos de metáfora;

2 - Contextualização da metáfora no discurso (Lynne Cameron, Alice Deignan, G. Steen): para esses pesquisadores, metáforas não são mais concebidas como "produtos pré-feitos" para que o nosso "estoque" cognitivo os disponibilize logo que tivermos ações discursivas. Elas são instrumentos linguísticos que também constroem um "contexto cognitivo dependendo da situação comunicativa dada". Logo, esses autores citados têm por objetivo pesquisar a metáfora na linguagem em uso no bojo da análise do discurso (SCHRÖDER, 2008, p. 58);

3 - Variedade cultural de metáforas: o pensador húngaro Zoltán Kövecses prossegue com a tradição de Lakoff e Johnson, porém afirma que eles superestimaram a universalidade de algumas estruturas metafóricas. Para ele, a metáfora pode também ser estudada do ponto de vista de sua variação cultural.

\begin{abstract}
As causas das quais universalidade e variedade da metáfora dependem incluem corporificação com a base neurocorporal, experiência sociocultural e processamento cognitivo, o que implica preferências cognitivas e estilísticas. Kövecses realmente busca uma integração dos três fatores: linguagem, cognição e cultura (SCHÖEDER, 2008, p. 58).
\end{abstract}

Lakoff e Johnson (2002, [1980]) pertencem à primeira geração de linguistas que concebem a metáfora como um fator que ultrapassa a questão da linguagem. Depois deles, outros pesquisadores apresentaram nuances dessa teoria, desenvolvendo modelos mais

\footnotetext{
${ }^{16}$ De acordo com FERRARI (2016, p. 98-99), esquemas imagéticos são estruturas de conhecimento que emergem diretamente da experiência corpórea pré-conceptual. Essas estruturas adquirem relevância no nível conceptual por derivarem dessa experiência. Tais experiências podem servir de domínio-fonte para a correspondência metafórica. Na metáfora ESTADOS SÃO LOCAIS, o domínio-fonte LOCAL pode ser concebido como REGIÃO DELIMITADA NO ESPAÇO, conforme ilustra o exemplo a seguir: "Ele está em depressão desde o início do ano."
} 
refinados para a análise de metáfora, tais como a Teoria da Integração Conceptual, a qual será discutida mais à frente.

Tendo em vista os propósitos de nosso estudo, a Teoria da Metáfora Conceptual (TMC) nos interessa em particular. Ela apresenta modelos que nos levam a entender como as metáforas da Economia são processadas e mapeadas do ponto de vista cognitivo, considerando-se a nossa análise dos vocábulos terminológicos metafóricos da Economia extraídos de corpora científicos que envolvem não somente questões cognitivas, mas também linguísticas. No entanto, além da explicitação desse modelo teórico, faremos também uma apresentação da Teoria da Integração Conceptual (TIC) a fim de justificar a opção de um dos modelos para a análise de nossos dados.

\subsubsection{A Teoria da Metáfora Conceptual (TMC)}

Conforme já dissemos anteriormente, a Teoria da Metáfora Conceptual (TMC) tem como marco inicial a obra de Lakoff e Johnson Metaphors We Live By, traduzida em português por Metáforas da vida cotidiana com o sentido de "as metáforas que nos guiam”. Desde o surgimento dessa obra, a metáfora passa a ser pensada como processo fundamental no uso cotidiano da linguagem: "Nosso sistema conceptual ordinário, em termos do qual pensamos e agimos, é basicamente de natureza metafórica" (LAKOFF; JOHNSON, 2002, [1980], p. 3).

De acordo com Ferrari (2016, p. 91), a metáfora refere-se à "noção de perspectiva, na medida em que diferentes maneiras de conceber fenômenos particulares estão associados a diferentes metáforas". Por exemplo, podemos falar metaforicamente do conceito de AFETO em termos de: temperatura (O diretor da empresa é uma pessoa fria). ${ }^{17}$

Conforme demonstrado por esse exemplo, a metáfora é um procedimento que envolve a conceptualização de um domínio de experiência em termos de outro. Isso permite que seja possível identificar um domínio-fonte (que envolve propriedades físicas e áreas relativamente concretas da experiência) para cada metáfora, e um domínio-alvo (aquele que queremos conceptualizar; referindo-se ao mais abstrato). Assim, esses

\footnotetext{
${ }^{17} \mathrm{O}$ corpo humano origina muitas metáforas conceptuais, sendo uma delas AFEIÇÃO É CALOR. Trata-se de metáfora primária que advém do fato de nosso corpo ser quente. Por extensão, uma pessoa fria (no nosso exemplo, o diretor da empresa) é aquela que não demonstra emoção.
} 
domínios podem ser representados pelo modelo a seguir, usando-se como exemplo a metáfora AFEIÇÃO É CALOR:

Domínio-fonte Domínio-alvo

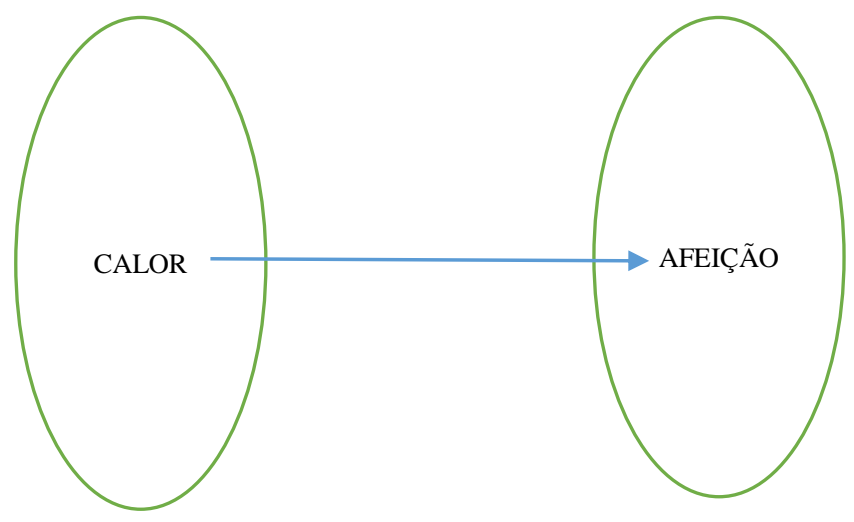

No âmbito dessa ótica, a projeção metafórica realizada entre esses dois domínios conceptuais (fonte e alvo), que se caracteriza por uma projeção unidirecional, demonstra a etiologia do processamento metafórico, revelando a informação da qual dispomos para que alcancemos o domínio de compreensão menos conhecido (OLIVEIRA, 2009, p. 64).

De acordo com Berber Sardinha (2007, p. 30-34), as principais características da metáfora conceptual podem ser resumidas da seguinte forma:

- conceptualização de um domínio de experiência em termos de outro;

- a expressão linguística é uma manifestação de uma metáfora conceptual. No exemplo "Nosso casamento está indo muito bem", essa expressão linguística advém da metáfora conceptual o AMOR É UMA VIAGEM;

- nessa perspectiva, há mapeamentos conceituais realizados entre domínios (domínio-fonte e domínio-alvo, conforme já explicado anteriormente); quando essas correspondências são ativadas, o mapeamento projeta os padrões de inferência do domínio-fonte para o domínio-alvo;

- essa teoria se contrapõe à visão lógico-positivista do mundo e propõe que não existem verdades absolutas, visto que as metáforas são culturais e procedentes de mapeamentos relevantes para certas civilizações ou ideologias;

- as metáforas são representações mentais, cognitivas; sendo abstratas, tomam forma na fala e na escrita por meio de expressões metafóricas; 
- seu acesso é normalmente automático; não precisamos de esforço para entender uma expressão metafórica, já que ela aciona de forma automática em nossa mente a metáfora conceptual correspondente;

- as metáforas conceptuais são convencionais, isto é, inconscientes; não parecem ser metáforas no sentido tradicional.

- o corpo humano é a origem de muitas metáforas conceptuais e essa projeção do corpo sobre a mente é chamada em inglês de embodiement (corporificação).

Do ponto de vista da análise dos termos metafóricos mais produtivos neste corpus de estudo, a abordagem teórica da TMC será mais útil, uma vez que, por meio de seu modelo de mapeamentos conceituais realizados entre domínios (domínio-fonte e domínio-alvo), poderemos fazer inferências sobre as analogias estabelecidas entre esses domínios. É o caso, por exemplo, do termo metafórico alavancagem, que conceitua uma experiência física em termos de rentabilidade financeira. Em termos físicos, essa alavancagem consiste na ação de levantar algum objeto sem requerer muito esforço, cujo procedimento normalmente é realizado por meio de uma máquina. Em Economia, essa analogia é estabelecida ao se combinar esse processo físico e as operações financeiras, com o objetivo de expressar um aumento da rentabilidade a partir de empréstimos. Tal analogia é facilmente percebida por meio do modelo teórico proposto pela TMC (Teoria da Metáfora Conceptual) apresentado a seguir:

Domínio-fonte Domínio-alvo

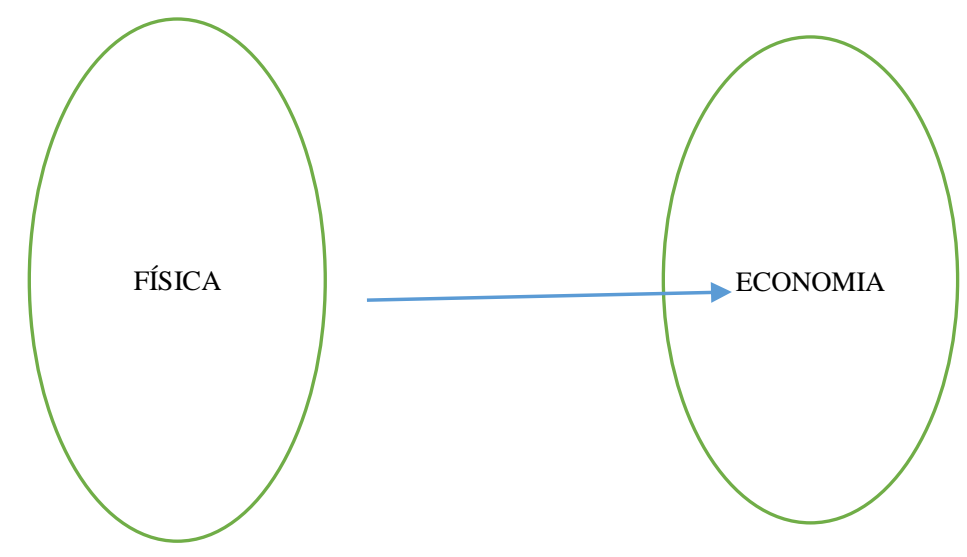

O conceito metafórico ECONOMIA É FÍSICA, projetado no mapeamento acima, nos permite realizar uma série de inferências, por exemplo, que se a ECONOMIA É 
FÍSICA, ela precisa de "máquinas" para fazer uma série de movimentos físicos, o que, no sentido metafórico, atende à ideia de que a Economia que funciona como uma máquina (Engenharia aplicada às leis da Física) visa a sua máxima eficiência (BERBER SARDINHA, 2007, p. 108). Daí o termo metafórico alavancagem financeira, ou simplesmente alavancagem, que implicam aumento da rentabilidade financeira sem esforço.

A seguir, verificamos um refinamento desse modelo de análise de metáforas conceptuais proposto pela Teoria da Integração Conceptual (TIC), outra vertente de pesquisa em metáfora bastante estudada na atualidade.

\subsubsection{A Teoria da Integração Conceptual (TIC)}

Outra abordagem predominante na análise de metáforas é a Teoria da Integração Conceptual (TIC), cujo modelo desenvolvido para análise de metáfora é o da chamada "mesclagem" (blending). Essa teoria, proposta pelo linguista francês Gilles Fauconnier (1944) em conjunto com o cientista cognitivo americano Mark Turner (1954) na década

de 1990, considera as "projeções conceptuais" e a "integração conceptual" como fenômenos que se situam no seio de numerosos domínios da forma de funcionamento do pensamento e da linguagem (OLIVEIRA, 2009, p. 61).

As duas correntes de análise de metáfora - a Teoria da Metáfora Conceptual e a Teoria da Integração Conceptual - são complementares: "as relações interdomínios identificadas pela TMC dá forma e condiciona o processo mais complexo da TIC" (FERRARI, 2016, p. 120). Dentro dessas duas perspectivas, a metáfora é percebida como um fenômeno de natureza cognitiva, uma operação intelectual e de categorização, de acordo com Ferrari (2016, p. 91).

A inovação trazida pela TIC reside no fato de que, além das relações estáveis metafóricas entre os domínios conceptuais (fonte e alvo) da TMC, ela engloba não somente esses domínios, como também permite explicar a inovação conceptual. Esse modelo encontra-se frequentemente presente em nossa atividade cognitiva, de forma que essa teoria permite explicar a inovação conceptual propondo uma complexificação da projeção metafórica (OLIVEIRA, 2009, p. 64).

A TIC representa um avanço sobre os modelos de análise da metáfora conceptual, sendo expandida e integrada à TMC. De acordo com Fauconnier e Turner (2002), o 
sistema conceptualizador humano é dotado de grande potencial simbólico para construir significados. A integração conceptual pode servir a diferentes propósitos, como, por exemplo, na compreensão de diversos tipos de raciocínios, dentre os quais, o pensamento metafórico.

De acordo com Schröder (2008), metáforas representam um "subcaso" de mesclagem. É por meio do blending que produzimos novidades que consistem em integrar estruturas parciais de dois domínios separados em uma única estrutura com propriedades emergentes dentro de um terceiro domínio.

A teoria da mesclagem de Fauconnier e Turner é vista como o cerne da habilidade cognitiva humana: a linguagem humana é apenas a "ponta do iceberg" da construção invisível que permanece enquanto pensamos e falamos. No processamento da fusão, mesclagem ou blending, conhecimento linguístico e não linguístico se mesclam. Tanto o domínio-fonte como o domínio-alvo da terminologia empregada por Lakoff e Johnson ("metáforas misturadas") contribuem para essa mesclagem.

A figura a seguir demonstra por meio de uma representação genérica o modelo proposto por Fauconnier e Turner (2002, p. 46) para a análise de metáforas de acordo com a proposta apresentada no parágrafo anterior.

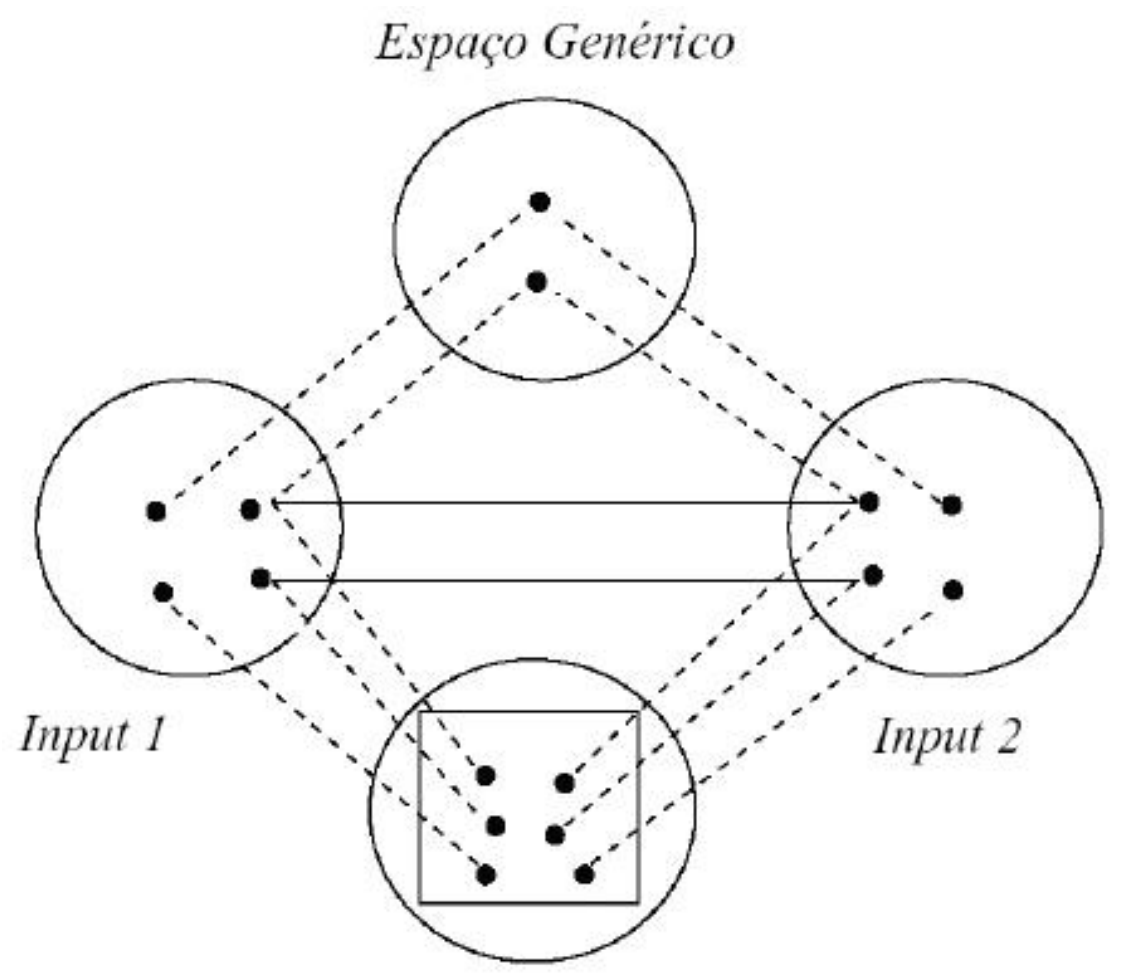

Espaço Mescla

Figura 4 - Modelo proposto por Fauconnier e Turner. 
Resumidamente, podemos observar por meio do modelo acima que existe uma operação pela qual se estabelece projeção parcial entre dois espaços iniciais (Input 1 e Input 2), ${ }^{18}$ a qual permite uma correspondência entre elementos análogos licenciados pelo Espaço Genérico (estrutura abstrata que os espaços iniciais têm em comum). Há ainda um quarto espaço: mescla (Blend), que reúne elementos projetados dos inputs, estabelecendo uma estrutura emergente própria.

Em 2006, Fauconnier e Turner refinam ainda mais o modelo da mesclagem: não falam mais de dois espaços Input, mas sim de uma rede de integração, a qual indica uma estrutura mais rica do que as mesclagens encontradas em suas primeiras abordagens. Nessa rede de integração, encontramos partes convencionais, mas também mapeamentos novos. Vejamos a aplicação desse modelo por meio da frase "Nosso casamento foi ontem. Para onde foram todos aqueles anos?":

[...] num primeiro nível, temos uma mesclagem entre input 1 eventos (casamento) e input 2 tempo (movimento experimentado por meio de espaço físico) que resulta no espaço mescla metáfora da estrutura do evento (nós passamos por um casamento como passamos por um parque, um tal evento pode ser rápido para uma pessoa e lento para outra), formando o novo input 1 , que juntamente com o input 2 longitude do tempo objetivamente medida ('todos aqueles anos'), choca com o input 3 experiência subjetiva ('ontem'). Por fim, este novo espaço mescla forma o input 1 ao qual se acrescenta um input 2, formando, por sua vez, um espaço mescla como resultado da fusão entre memória e espaço físico, de modo que o resultado final consiste em vários espaços input de níveis diferentes. (SCHRÖDER, 2008, p. 43-4)

Contudo, Oliveira (2009, p. 68) explica que nem sempre é possível realizar a mesclagem. Para fazer tal afirmação, ela se vale da metáfora "Ele é um açougueiro", em que o cirurgião do Input 1 se refere ao mundo da medicina, e o açougueiro do Input 2 se refere ao mundo do açougue correspondendo à mesma pessoa dentro do blending, ${ }^{19}$ tratando-se, portanto, da mesma entidade. Porém, essa integração nem sempre ocorre. É o caso, por exemplo, do termo coração de leão usado na cardiologia para se referir a um coração artificial. Percebe-se que o Input 1 faz referência ao mundo zoomórfico (leão); já no Input 2, faz-se alusão ao mundo da medicina, não dizendo respeito à mesma entidade, uma vez que são de universos distintos.

\footnotetext{
${ }^{18} \mathrm{O}$ Input 1 equivale ao domínio-fonte, enquanto o Input 2 equivale ao domínio-alvo.

${ }^{19}$ Para Ferrari (2016, p. 126), na metáfora "Aquele cirurgião é um açougueiro", a inferência emergente de que o cirurgião é incompetente não pode ser explicada por meio do modelo da TMC, já que a inferência surge apenas na mescla, motivada pela incongruência entre o objetivo de curar (projetado do domínio da cirurgia) e os métodos utilizados (projetados do domínio do açougue).
} 
Por último, queremos considerar, conforme já dissemos anteriormente, que não adotaremos esse modelo da TIC, pois o objetivo deste trabalho é o de demonstrar quais são os traços conceptuais que ligam o domínio-fonte ao domínio-alvo, porquanto a metáfora aparece como uma estrutura conceitual que mostra o deslocamento (déplacement) de um domínio a outro, na transposição de uma ordem a outra. A metáfora conceptual permite emprestar os traços conceptuais de um domínio-fonte a ser transportado para o domínio-alvo. Além do mais, nem sempre será possível analisarmos as metáforas de nosso corpus sob o viés da TIC pelo fato de nem sempre haver mesclagem ou mesmo pelo fato de essa análise extrapolar os limites de análise propostos para este trabalho.

\subsection{Teoria Sociocognitiva da Terminologia (TST)}

Para compreendermos a importância da Teoria Sociocognitiva da Terminologia para o estudo das metáforas de especialidade, devemos fazer um breve histórico sobre a origem dos estudos terminológicos a fim de que possamos entender a sua emergência. Lembramos que a metáfora era repelida nos estudos tradicionais nessa área pelo fato de ser considerada como um fator gerador de polissemia - o que devia ser evitado na linguagem terminológica, de acordo com a Teoria Geral da Terminologia (TGT). ${ }^{20}$

De acordo com Temmerman (2000, p. 158), a Terminologia tradicional era representante de uma visão estruturalista da linguagem ligada ao Objetivismo: o que explicaria essa objeção à polissemia. ${ }^{21}$ Porém, uma nova visão sobre a importância do papel da polissemia e da metáfora em Terminologia surge a partir da década de 1990, perdurando até o início dos anos 2000, quando esses pressupostos teóricos e metodológicos são colocados à prova por revisões feitas entre os estudiosos da Terminologia. No bojo desses novos trabalhos, a Terminologia é considerada, sobretudo, como fator comunicativo e social. Para Barros (2004, p. 36), questionamentos atuais a respeito do modelo normalizador propostos inicialmente pela Teoria Geral da

\footnotetext{
${ }^{20}$ De acordo com Krieger e Finatto (2016, p. 31), a Escola de Viena, corrente precursora dos estudos terminológicos, que considera Eugen Wüster como seu fundador (1931), visava "à padronização de termos técnicos e, por vezes, o aparelhamento das línguas para responderem às exigências de uma comunicação profissional eficiente".

${ }^{21}$ Eugen Wüster (1898 - 1977), "inaugurador" da TGT, foi engenheiro, industrial e professor. Ele defendia uma série de valores representantes de uma época em que o espírito de desenvolvimento da tecnologia e da normalização terminológica eram baseados em conceitos rígidos que vigoravam na Alemanha dos anos 1920.
} 
Terminologia (THT) direcionam as pesquisas nesta área para a Socioterminologia, cujos valores são expressos, por exemplo, pelo grupo de estudiosos da Teoria Comunicativa da Terminologia (TCT), proposta por alguns pesquisadores, dentre os quais destacamos Maria Teresa Cabré. ${ }^{22}$

Na perspectiva da Socioterminologia, a polissemia passa a ser prevista, aceita e estudada em trabalhos terminológicos, de forma que começam a surgir estudos a respeito da função da metáfora nos textos de linguagem especializada - a exemplo dos de Temmerman (2000), autora que incluiu os estudos da metáfora em sua análise -, bem como reflexões voltadas a uma Teoria Sociocognitiva da Terminologia.

Conforme já dissemos anteriormente, se na TGT a polissemia era considerada como um fator que dificultava a "normatização" dos termos, na Teoria Sociocognitiva a metáfora ocupa um lugar especial na Terminologia, sobretudo no que se refere à comunicação do saber científico. Em Towards new ways of terminology description - the sociocognitive approach (2000), Temmerman realiza uma revisão crítica da teoria tradicional da Terminologia, a qual preconizava, por exemplo, o afastamento da metáfora do núcleo terminológico, firmando, neste novo viés teórico, o papel central da metáfora no saber terminológico.

Para essa teoria, o "raciocínio" metafórico facilita a compreensão de fatos novos, processos ou outras categorias do saber científico. Ele é usado para explicar novas situações com o auxílio da capacidade criativa do ser humano baseada em experiências humanas. Cognitivistas defendem que a linguagem é um elo entre o pensamento e a compreensão, sendo a metáfora um dos elementos que permite a realização dessa atividade cognitiva. Nesse contexto, ela é considerada um mecanismo do pensamento, um elemento que se interpõe entre produção de sentido, imagem, representação conceptual e conhecimento geral enciclopédico. ${ }^{23}$

A fim de demonstrar e tecer considerações sobre as afirmações acima dirigidas em torno da metáfora, Temmerman (2000), por meio de um corpus da Biotecnologia, descreve, por exemplo, de que forma o raciocínio metafórico é utilizado na denominação e na categorização de determinadas áreas do conhecimento científico e de que forma isso deixa traços na linguagem. Para realizar esse trabalho, ela se concentra na Genética -

\footnotetext{
${ }^{22}$ A TCT, cujos fundamentos epistemológicos começam a se destacar a partir da década de 1990, valoriza os aspectos comunicativos da linguagem especializada em "oposição" ao objetivo normalizador da TGT.

${ }^{23} \mathrm{O}$ conhecimento enciclopédico se refere às informações armazenadas na memória de longo prazo a respeito de um determinado tópico.
} 
subárea da Biotecnologia -, realizando a análise de amostras de linguagem utilizadas pelos cientistas para explicar o funcionamento dos genes.

O estudo desse corpus permitiu à autora verificar, por exemplo, que as analogias realizadas por esses cientistas possibilitaram a formação de "novas terminologias" baseadas nos Modelos Cognitivos Metafóricos (m-ICM). Esses modelos organizaram essa forma de conhecimento de maneira que alguns tipos de "analogias" resultaram em "neolexicalizações"24 do tipo:

- DNA É UMA LÍNGUA (genes são mensagens escritas em uma determinada "linguagem");

- DNA É UM ATLAS (a totalidade de localização de informação genética de um organismo [o genoma] pode ser descrita em mapas);

- DNA É UM SOFTWARE (DNA é um software que pode percorrer a célula);

- DNA É UM FILME (DNA é um filme que pode ser "lido" por um retroprojetor). ${ }^{25}$

Temmerman (2000, p. 156) considera nesse tipo de corpus que o ICM da informação em Genética é fonte para a criação de $s u b-m-I C M s$, que são as realizações desse conceito em outros subdomínios relacionados a essa área de conhecimento. $\mathrm{O}$ primeiro deles, DNA É UMA LÍNGUA, baseia-se na experiência de que uma informação é expressa em uma linguagem. O segundo, DNA É UM ATLAS, é estabelecido a partir de nossas experiências geográficas descritas, normalmente, em mapas. O terceiro, DNA É UM SOFTWARE, origina-se da experiência de que a informação é frequentemente armazenada e disponibilizada em formato eletrônico. O quarto, DNA É UM FILME,

\footnotetext{
${ }^{24}$ De acordo com Temmerman (2000, p. 183), essas neolexicalizações surgem a partir da ideia de que Modelos Cognitivos Metafóricos funcionariam como gestalts (estruturas que auxiliam a mente a organizar e a compreender metáforas), alguns universais e outras que variam de cultura para cultura.

${ }^{25}$ Temmerman (2000, p. 184): DNA IS A LANGUAGE. Genes are messages written in a language. This is a first sub-m-ICM based on the experience that information is often expressed in a language [...]. DNA IS AN ATLAS OF MAPS. The totality of the localisation of genetic information of an organism (the genome) can be depicted on maps. Just like explorers of the globe depicted information on the localisation of geographical phenomena that they had been able to observe maps, geneticists mark the position of genes on genetic maps. [...]. DNA IS SOFTWARE. DNA is software which can be run by the cell. This a third sub-m-ICM based on the experience that information is often stored and made available in an electronic format [...]. DNA IS A FILM. DNA is a film which can be 'read' by a projector. This is a fourth sub-mICM based on the experience that information can be stored and made available on film-tapes [...].
} 
fundamenta-se na experiência de que essa informação pode ser armazenada e disponibilizada em forma de filme (películas).

Em nosso corpus de análise, há muitos ICMs (Modelos Cognitivos Metafóricos) que serão estudados na Parte III (Capítulo 6) desta tese. Um dos conceitos metafóricos que se sobressai neste corpus de pesquisa é o domínio da guerra: ECONOMIA É GUERRA. Esse tipo de compreensão é um "ICM" que gerará uma série de termos, tais como ataque especulativo, ativos defensivos, ativos estratégicos, guerra comercial, guerra fiscal, guerra das moedas e guerra de preços. Esses termos metafóricos permitem compreender o conceito de cada uma dessas lexicalizações em Economia, a partir da experiência concreta da guerra. Na formação sintagmática ataque especulativo, compreende-se por meio da metáfora ataque um tipo de acontecimento em que a Economia de um país sofre uma investidura contra a moeda local.

Em seu livro, Temmerman (2000, p. 205) trata ainda outro aspecto importante sobre as funções das metáforas terminológicas na abordagem da Teoria Sociocognitiva: no caso, as que apresentam uma função didática e uma função criativa. As metáforas didáticas cumprem a função de ajudar a compreender saberes técnicos e científicos. As de ordem criativa dão origem a lexicalizações que podem se consolidar e serem aceitas como termos de uma linguagem especializada cuja função seria, essencialmente, cognitiva. Para Temmerman (2000, p. 211), as metáforas criativas e as didáticas são diferentes, pois as primeiras são responsáveis pela criação de neologismos científicos, ao passo que as segundas servem a um contexto particular de situações didáticas, responsáveis pela base de compreensão de um novo domínio de experiência.

Em nosso corpus de estudo, estudamos os termos já consolidados uma vez que eles emanam de textos especializados que circulam entre especialistas na área de Economia. Algumas dessas unidades terminológicas também podem ser encontradas em corpora que circulam para outro tipo de público - no caso, a mídia. No discurso não especializado ocorre, por exemplo, a unidade bomba inflacionária, neologismo que provavelmente não se lexicalizará como termo na linguagem científica, uma vez que atende sobretudo a necessidades relacionadas a fatores expressivos próprios da linguagem jornalística. $^{26}$

\footnotetext{
${ }^{26}$ Em relação às metáforas criativas, Temmerman (2000, p. 208) explica que elas dão origem a neologismos que podem se consolidar e serem aceitos como termos de uma linguagem especializada cuja função seria, essencialmente, cognitiva, diferenciando-se das metáforas didáticas de ordem comunicativa.
} 
De acordo com Temmerman (2000, p. 205), as metáforas didáticas têm a função de auxiliar a compreender saberes técnicos e científicos expostos nos tipos de texto, tais como artigos de pesquisadores, manuais para especialistas e textos de popularização. No primeiro tipo de texto, no caso representado pelos artigos, os termos resultam de um pensamento analógico consciente ou subconsciente. No segundo caso, manuais para especialistas, eles são dirigidos a usuários com algum conhecimento científico. Por último, no terceiro tipo, o público é leigo; nessa situação, a analogia se torna mais explícita, ocasionada pela grande necessidade de esclarecimento do assunto para um tipo de público que não seja familiarizado com o tema. Em relação aos termos de nosso corpus, algumas metáforas cumprem essa função didática, que é o caso daquelas que emanam dos artigos científicos.

Temmerman (2000, p. 212) defende também que, para a teoria sociocognitiva, é importante estudar a história da área de especialidade em questão, uma vez que a diacronia tem um papel fundamental na constituição das metáforas, e, ao compreendermos a história da evolução dos termos, poderemos entender a sua origem. Para os propósitos deste trabalho, não seguiremos esse percurso, uma vez que esse tipo de estudo extrapolaria os limites desta tese, cujo recorte de análise dos termos é sincrônico.

\subsection{Metaforização e Terminologia}

Após ter demonstrado no capítulo anterior em que momento e por que razão a metáfora passa a ser incluída nos estudos terminológicos, após ter sido rejeitada pelos estudos terminológicos tradicionais, discutiremos neste capítulo as relações entre metáfora e Terminologia, bem como o status que ela ocupa nos estudos de linguagens especializadas na atualidade.

Impulsionada pela Linguística Cognitiva, as metáforas terminológicas começaram a ser reconhecidas, extrapolando o campo da linguagem, com o advento da TCT (Teoria Comunicativa da Terminologia), da Socioterminologia, e especialmente com a Teoria Sociocognitiva da Terminologia, passando dessa forma a serem compreendidas como necessárias para as ciências. ${ }^{27}$

\footnotetext{
${ }^{27}$ De acordo com Oliveira (2011, p. 53), a ISO TC 37 faz uso do termo metáfora e admite seu emprego em Terminologia quando há um empréstimo entre disciplinas, quando uma palavra da língua geral ou de outra
} 
A metáfora terminológica está longe de ser apenas um fato de linguagem. Ela é essencialmente uma maneira de pensar. É um empréstimo de imagem que ocorre a partir de uma prática social, tornando-se a expressão de um novo conceito (ASSAL ${ }^{28}$ apud OLIVEIRA, 2009, p. 30). Essa definição trata de estabelecer limites entre o papel da metáfora da linguagem geral e o da metáfora terminológica, de maneira que devemos apresentá-la como um elemento detonador das conceptualizações cognitivas no domínio das ciências. Ela tem um papel importante para a apreensão de novos conceitos.

Para Hermans $^{29}$ (1989, p. 14, apud OLIVEIRA, 2009, p. 31), as epistemologias atuais afirmam que todas as ciências se fundamentam em uma operação de metaforização. Em função dessas definições, Oliveira (2009, p. 31) afirma que a identificação da metáfora em terminologia supõe o reconhecimento de dois níveis: um linguístico e outro cognitivo, os quais interagem constantemente. O especialista pensa por meio de um sistema conceitual, apoiando-se nesse tipo de metáfora que se fundamenta sobretudo na metáfora conceptual, que associa, em ciência, a compreensão e a visão.

Para Oliveira (2009, p. 32), o emprego eficaz de uma metáfora ocorre quando o cientista faz uma utilização apropriada desse recurso semântico. Ele deve escolher uma boa metáfora para representar uma determinada situação, obtendo um quadro de reflexão e de uma visão adaptada da realidade. Ao evocar a metáfora, o especialista tenta construir uma visão de mundo e uma adequação desse fenômeno com sua própria percepção. $\mathrm{O}$ raciocínio metafórico possibilita a apreensão do conhecimento complexo de uma forma rápida e flexível, facilitando a compreensão do conceito ao fornecer, por meio da analogia, um suporte imaginativo de algo já conhecido.

A pesquisadora Martins (2004, p. 132) ainda vai um pouco mais longe ao afirmar que em toda tradução de metáfora há uma perda cognitiva. Em ciência, ela é um acesso epistêmico ao mundo: "Sua função inovadora, deve-se à capacidade de ser insubstituível.” As descobertas em ciência exigem inovação e ampliação de vocabulário, que se obtêm por meio da metaforização dos nomes e das expressões já utilizadas, e das potencialidades significativas dos sistemas linguísticos. Uma vez constituídas as teorias, as metáforas persistem, estabelecendo-se uma relação entre metáforas e teorias, ou seja, as metáforas são elementos constitutivos dessas teorias porque desempenham a função de

área de especialidade é emprestada e designada a um novo conceito, a exemplo de "memória" tanto como capacidade do cérebro humano quanto como capacidade de armazenamento temporário de um computador. ${ }^{28}$ ASSAL, J-L. La métaphorisation terminologique. Terminology Update, v. 28, n. 2, p. 22-4, 1995.

${ }^{29}$ HERMANS, A. La définition des termes scientifiques. Meta, Montréal, v. 34, n. 3, p. 142-5, 1989. 
estruturar e organizar o trabalho de investigação e construir o saber científico. Assim, apesar de a ciência dita tradicional valorizar a univocidade conceptual, essa perspectiva apresenta-se como uma ilusão, uma vez que as linguagens de especialidade se elaboram também mediante processos metafóricos.

Para Oliveira (2009, p. 52), a metáfora terminológica em seu objeto de investigação tem uma função pedagógica, uma vez que ela se coloca a serviço do conhecimento, fazendo "desfalecer" noções abstratas, facilitando a compreensão de fenômenos complexos, conforme já dissemos anteriormente. Ela, portanto, esclarece e facilita a visualização de conceitos abstratos. A metáfora tem um papel inegável na comunicação especializada. É um fator comunicativo necessário ao desenvolvimento e à apresentação das ideias.

A metáfora pode também auxiliar um projeto científico do ponto de vista educacional ou pedagógico, auxiliando na explicação de um princípio ou uma teoria, no aprendizado, no ensino, na rememoração de um conceito teórico e na descrição de métodos (MARTINS, 2004, p. 137). Assim, a metáfora pode fornecer uma explicação satisfatória para um método, um fenômeno ou uma teoria.

No entanto, as vantagens das metáforas no pensamento científico não se resumem somente ao seu papel pedagógico; elas podem ainda ser ilustrativas ou exercer um papel criativo, pois efetuam novas previsões, demonstrações ou experiências, apresentam novas entidades ou conceitos teóricos, executam novas inter-relações estruturais ou similaridades entre entidades teóricas. Em resumo, elas criam novas categorias de entidades ou propriedades e novas relações funcionais. Em suma, uma metáfora pode demonstrar como a descrição literal pode ser equivocada e a descrição metafórica revelar uma descrição mais adequada.

Já as metáforas heurísticas, que mediam e conduzem a formação de um novo conceito ou de uma teoria científica, conforme a própria definição de heurística como parte do método científico, são metáforas que nos auxiliam a conceber novas abordagens para problemas conhecidos. Elas ajudam na compreensão de algum fenômeno, servindo para catalisar o pensamento.

Essas metáforas surgem da relação nova entre dois referentes, sendo que o conceito novo ocorre a partir do concreto para o abstrato. Em Economia, por exemplo, o domínio-alvo estabelece muitas analogias com o domínio-fonte da Física, uma vez que os "sistemas físicos ainda são simples em comparação aos econômicos servindo como 
paradigma que permite reduzir a complexidade do conceito a ser compreendido" (AJZENTAL, 2015, p. 22).

Porém nem sempre essas metáforas são "bem-formadas". O uso descuidado desse tipo de polissemia pode trazer mais confusão do que auxílio. Analisando o papel das metáforas e analogias na história da ciência ocidental, Gentner e Jeziorski ${ }^{30}$ (1993, s.p. apud Ajzental, 2015, p. 24) mostram que diferentes grupos irão empregar tais comparações de maneiras diversas, adotando diferentes critérios tácitos para ser considerado válido o seu emprego. Uma metáfora bem-empregada tem a capacidade de surpreender com implicações ainda não percebidas. Esses novos desdobramentos são o que tornam as metáforas tão úteis à investigação científica. A necessidade, então, da metaforização repousa no fato de ela estabelecer ligações entre a linguagem da ciência e o mundo que ela se propõe a explicar. Em entrevista concedida a nós em 19 de dezembro de 2017, Ajzental, autor do livro Complexidade aplicada à economia, considera que a metáfora da "guerra", ao cunhar termos como guerra mercadológica ou guerra fiscal, não é uma metáfora "bem-empregada", pois, para ele, Economia não é guerra, mas sim competição, havendo, portanto, um exagero na denominação do termo na compreensão da guerra.

A biologia evolucionária é outro domínio-fonte do qual a Economia se apropria e com o qual cria analogias, tendo como objetivo abordar a organização econômica como um processo dinâmico, fruto de interações, competições, mudanças estruturais, escassez de recursos, entre outros elementos. De acordo com Ajzental (2015, p. 166-8), os economistas Sumner, Ward e Boas "abraçaram" o evolucionismo e as analogias orgânicas. O economista neoclássico John Bates Clark (1847 - 1938), por exemplo, seguiu essa linha, entrelaçando sua obra Filosofia da riqueza (1885) com metáforas orgânicas e imagens tiradas da biologia spenceriana. Da mesma forma, diversos outros economistas evolucionários fizeram uso em larga escala de termos que provêm da linguagem teórica da biologia.

Entre as características que diferenciam as metáforas de língua geral da linguagem especializada, podemos destacar o fato de que a metáfora terminológica se "lexicaliza" mais rapidamente. As metáforas terminológicas podem ser úteis, por exemplo, na Medicina, porque formam um fundo cultural comum entre o médico e o paciente. É o caso, por exemplo, de "pé de atleta”, cuja denominação na Medicina é igual a intertrigo

${ }^{30}$ GENTNER, D.; JEZIORSKI, M. The Shift from Metaphor to Analogy in Western Science. In: ORTONY, A. (Ed.). Metaphor and thought. 2 ed. Cambridge: Cambridge University Press, 1993, p. 447-80. 
(OLIVEIRA, 2009, p. 52). O "deslocamento" da palavra que se torna uma metáfora terminológica efetua-se a partir do significado de um contexto geral do senso comum para uma reformulação particular.

Do ponto de vista morfossintático, elas se comportam da mesma forma que as metáforas da língua geral, não havendo mudança de seus formantes, inserindo-se dentro de um cenário de atividade especializada reservado a um grupo profissional. Elas também são desprovidas de valor afetivo, conotativo e ambíguo para, em seguida, se lexicalizarem de forma que dissipem sua imprecisão nocional. $\mathrm{O}$ pesquisador tcheco Rostislav Kocourek $^{31}$ (apud Martins, 2004, p. 4) menciona que a metaforização se encontra a serviço do vocabulário das áreas técnicas e se apresenta como altamente produtiva. Contudo, somente as metáforas ou as metonímias lexicalizadas interessam à Terminologia, uma vez que o processo de "figuração" já foi alvo de integração no sistema lexical da linguagem de especialidade em questão.

As metáforas terminológicas são, assim, uma forma de extensão semântica que, no contexto das linguagens de especialidade, assumem o valor de unidades terminológicas - a unidade mínima da Terminologia -, pois representam conceitos dessas mesmas linguagens. Podemos assim concluir que, em um estudo que tenha por interesse analisar as motivações metafóricas de uma determinada área de conhecimento, deve-se observar de que forma essas metáforas são constituídas.

\footnotetext{
${ }^{31}$ Kocourek, R. La langue française de la technique et de la science, 1991, p. 167.
} 


\section{PARTE II}

\section{METODOLOGIA E PROCEDIMENTOS METODOLÓGICOS DA PESQUISA - CORPORA}

\subsection{Constituição dos corpora: compilação e tratamento}

Segundo os pesquisadores Almeida, Oliveira e Aluísio (2006, p. 42), desde pelo menos 1996, a informática tem contribuído para os resultados de estudos que envolvem pesquisas sobre Terminologia no Brasil. Isso se deve ao crescimento de pesquisas na área de Linguística Computacional e de Linguística de Corpus, com o consequente desenvolvimento e aprimoramento de ferramentas computacionais direcionadas ao Processamento de Língua Natural (PL), interferindo também na prática terminográfica.

Realizar um estudo em Terminologia sem fazer uso de ferramentas eletrônicas é praticamente inviável no atual contexto dos estudos terminológicos. Finatto (2004, p. 2) afirma que a Terminologia é uma ciência "transdisciplinar" que tem se aproximado cada vez mais do processamento de grandes acervos textuais com o objetivo de identificar particularidades lexicais e, por meio desses recursos, obter "produtos linguísticos", tais como dicionários, com menos dificuldades ou em menor tempo.

Para Barros (2006, p. 25), a Linguística Computacional é uma ciência multidisciplinar, visto que ela apresenta uma interface com diversas áreas, tais como a Computação e a Lógica Computacional, a Inteligência Artificial e a Linguística. Essa ciência tem apresentado recursos de criação de instrumentos como composição, análise, manipulação e processamento de dados linguísticos em textos, fazendo com que a Linguística Computacional contribua possa contribuir com subsídios de extrema importância para a Terminologia/Terminografia. Assim, trabalhar com Terminologia na era da informática compreende:

[...] criar um conjunto de procedimentos automatizados ou semiautomatizados que deem suporte às tarefas envolvidas no trabalho terminológico, quais sejam: 1. criação de corpora descartáveis; 2. extração automática de candidatos a termos desses corpora; 3. inserção dos termos numa ontologia (mapa conceitual); 4. elaboração e edição de fichas terminológicas; 5. elaboração e constante atualização da base definicional; 6. elaboração das definições; 7. edição de verbetes; 8. difusão dos dados para intercâmbio com outras aplicações e usuários. (ALMEIDA; OLIVEIRA; ALUÍSIO, 2006, p. 42).

Para atingir os propósitos traçados por nossa pesquisa, dentre as diversas possibilidades dos procedimentos acima apontadas, exploramos apenas alguns desses 
passos, como a criação de corpora e extração dos candidatos a termos, uma vez que, para alcançar os objetivos de nosso estudo, fizemos prospecção de termos da Economia para filtragem de metáforas. O que justifica o uso dessas ferramentas em nossa pesquisa é o fato de que, por meio dos corpora eletrônicos, conseguimos investigar de uma forma mais original os conceitos apresentados por discursos especializados:

\begin{abstract}
Mieux encore, on peut dire que la machine, au contraire de l'humain, permet une véritable 'mise à plat' de moyens d'expression mis en oeuvre dans les discours spécialisés et donc de obtenir une image de la variation linguistiquement plus conforme à la réalité. De plus, cette image est non seulement plus fidèle, mais infiniment plus détaillée, résultat d'une exploration systématique du texte de LSP. En bref, on peut dire que pour analyser l'usage, le corpus est outil incontournable. ${ }^{32}$ (AUGER, 2001, p. 191-2)
\end{abstract}

Esse tipo de processamento baseado em corpus possibilita a análise dos dados de forma empírica. Como observa Tagnin (2002, s.p.), o foco concentra-se no uso medido pela frequência de ocorrências, o que garante observações a partir de dados precisos, salvaguardando dessa forma julgamentos prévios sobre fatos da língua (TRASK, 2004, p. 68).

Levando em consideração que este estudo do ponto de vista metodológico coletou os seus termos fazendo uso de algumas ferramentas da Linguística de Corpus, abordagem ou metodologia que, de acordo com Berber Sardinha (2004, p. 3), ocupa-se da coleta e da exploração de corpora prospectados com critérios que têm por objetivo servir de instrumentação para a pesquisa de uma língua ou de uma variedade linguística, torna-se importante mencionar que há pesquisas sobre metáfora com base na Linguística de Corpus que a estudam do ponto de vista dessa ciência linguística. No entanto, salientamos que o nosso trabalho não é uma pesquisa de Linguística de Corpus; apenas usamos alguns de seus procedimentos para facilitar a coleta e o processamento dos dados. ${ }^{33}$

Vejamos, a seguir, alguns desses aspectos por meio de um artigo publicado em 2009 por Berber Sardinha, intitulado "Questões metodológicas de análise de metáfora na perspectiva da Linguística de corpus", com o objetivo de demonstrar propostas

\footnotetext{
${ }^{32}$ Mais propriamente, podemos dizer que a máquina, ao contrário do humano, permite um real 'achatamento' dos meios de expressão utilizados em discursos especializados e, portanto, obter uma imagem da variação linguisticamente mais consistente com a realidade. Além disso, essa imagem não só é mais fiel, mas infinitamente mais detalhada, fruto de uma exploração sistemática do texto do LSP. Em suma, podemos dizer que para analisar o uso, o corpus é uma ferramenta essencial. [tradução nossa]

${ }^{33}$ A principal meta a ser alcançada com o tipo de compilação deste trabalho é a observação de contextos para a busca de unidades terminológicas metafóricas, posto que o texto em formato eletrônico facilita o cumprimento dessas tarefas.
} 
metodológicas no processo de identificação de metáforas em uma interface automatizada, focalizando duas dessas abordagens: corpus-based (procedimento de seleção de candidatos e de uso de concordanciador) e corpus-driven (nesse caso, o autor discute os programas KeyWords e o Identificador de Metáforas) que serão comentados na próxima seção.

\subsection{Questões metodológicas na análise de metáforas}

\subsubsection{Identificação de metáforas em corpus}

Quantidade de dados

Atualmente, há grande disponibilidade de material textual em formato eletrônico. No bojo dessa realidade, a compilação de corpora facilmente ultrapassa a quantidade de milhões de palavras. Dessa forma, o volume de dados influencia os procedimentos de pesquisa e, dependendo do tamanho do corpus, não é possível realizar uma leitura integral para a identificação de metáforas. Embora haja instrumentação computacional, é necessária a seleção de candidatos.

De acordo com Berber Sardinha (2009), essa seleção de candidatos depende do tipo de pesquisa, havendo duas possibilidades de estudo, conforme veremos a seguir:

- seletiva

Nesse tipo de estudo, o pesquisador seleciona os candidatos à metáfora considerados mais interessantes para a pesquisa, de acordo com os seus objetivos.

\section{- abrangente}

$\mathrm{Na}$ pesquisa abrangente, o pesquisador tenta abarcar todos os candidatos (ou o maior número possível deles) para alcançar a maior diversidade de metáforas que compõem o corpus. 
$\underline{\text { Pesquisa em corpora }}$

Os tipos de pesquisa podem variar de acordo com os objetivos do estudo e o tipo de corpus em análise. Para Berber Sardinha (2009, p. 83), a seguinte configuração é naturalmente comum:

i. Corpora de língua geral

- ultrapassam centenas de milhões de palavras, chegando mesmo a bilhões;

ii. Corpora especializados

- são formados por gêneros ou registros específicos.

No caso de nossa pesquisa, estamos tratando de corpora especializados, uma vez que selecionamos textos de gêneros discursivos científicos da área de Economia com o objetivo de identificar metáforas de um determinado tipo de corpus.

$\underline{\text { Metodologias na identificação de metáforas }}$

Segundo Berber Sardinha (2009, p.85), há duas metodologias gerais que partem da metáfora linguística descrita a seguir:

- baseada em corpus (corpus based);

- no corpus based, o pesquisador delimita os candidatos à metáfora de antemão;

- movida a corpus (corpus driven): Em corpus driven, o pesquisador começa por uma prospecção do corpus, sem delimitar de imediato quais palavras seriam candidatas (geralmente, com auxílio computacional).

Nesse segundo tipo de pesquisa, a seleção de candidatos é realizada com base em uma prospecção feita por programas de computador. Berber Sardinha (2009, p. 89) explica que essa seleção pode ser realizada de diversas formas utilizando-se ferramentas computacionais como o KeyWords, que faz parte da suíte WordSmith Tools, o Identificador de Metáforas do CEPRIL (cujo serviço não estava em funcionamento no período de nossa pesquisa) e o Semantic Similarity (também conhecido por Semantic 
Distance), que funciona apenas com dados do inglês (o que está fora de nosso escopo, pois nossa pesquisa estuda somente as metáforas do português brasileiro).

Ambas metodologias apresentam elementos dos paradigmas quantitativo e qualitativo. Para Berber Sardinha (2009, p. 85), ao adotar essas metodologias, o pesquisador necessita decidir se um candidato à metáfora é de fato representativo desse tipo de processo semântico. No caso de nossa pesquisa, podemos afirmar que ela é abrangente e movida a corpus driven, uma vez que não delimitamos quais palavras seriam candidatas. A seleção das metáforas foi feita manualmente após a triagem dos termos do corpus etiquetado por meio do programa TreeTagger (ferramenta eletrônica desenvolvida para anotação de texto com partes do discurso e informações sobre o lema).

\section{Metodologias bottom-up e top-down}

Na literatura sobre metáfora, há duas metodologias adotadas para esse tipo de estudo, conforme podemos ver a seguir:

- bottom-up (ascendente): o analista parte da metáfora linguística (estrutura os sistemas conceituais a partir do que compreendemos do mundo e da forma como agimos nele), e não da metáfora conceptual (aquela estruturada no pensamento humano);

- top-down (descendente): o analista parte da metáfora conceptual para encontrar as metáforas linguísticas.

Para a triagem das metáforas encontradas a partir dos termos selecionados para a nossa pesquisa, foram selecionadas as metáforas linguísticas, isto é, unidades de metáfora expressas na escrita. Após a seleção dos termos metafóricos, fizemos um "mapeamento" dos domínios cognitivos estabelecendo uma tipologia de conceitos metafóricos.

\subsection{Características dos corpora}

Para Berber Sardinha (2004, p. 16-23), um corpus pode ser definido como a presença de uma coletânea de dados linguísticos naturais legitimados pelo computador. Dados linguísticos referem-se aos textos autênticos que são escolhidos para serem usados como base para pesquisa linguística. 
Resumidamente, o autor define as principais características de um corpus:

- deve ser composto de textos naturais, ou seja, que não podem ter sido criados em linguagem artificial;

- seu conteúdo deve ser escolhido criteriosamente, obedecendo a um conjunto de regras estabelecidas por seus criadores de forma que o corpus coletado corresponda às características desejadas para os objetivos propostos pela pesquisa;

- deve ser representativo em sua extensão, porém não é possível estabelecer o tamanho ideal da amostra de um corpus. A solução para bons resultados da pesquisa é tornar a amostra a maior possível a fim de que se aproxime ao máximo da "população" da qual ela se origina.

Com base nessa definição, podemos afirmar que o corpus constituído para este tipo de estudo atende a esses critérios básicos. Fomos também os mais seletivos possível na escolha de seus exemplares com o intuito de podermos estudar uma variedade específica de textos de onde as unidades terminológicas metafóricas foram captadas para que analisássemos o seu processamento.

A seguir, listamos algumas outras características apresentadas pelo corpus constituído para o nosso estudo, tais como aspectos relativos ao seu tamanho:

- autenticidade: composto por textos autênticos escritos na variedade linguística do português brasileiro; portanto, monolíngue;

- recorte temporal: sincrônico - compreende o período de 2005 a 2015;

- finalidade: estudo do processamento das metáforas terminológicas da Economia;

- formato: eletrônico - arquivos em PDF convertidos em formato TXT;

- tamanho: grande, com mais de 28.000.000 de palavras (tokens) / 91.000 (types).

Em relação aos gêneros científicos doravante estudados nesta tese, destacamos as características a seguir: 


\section{a) artigos}

Artigo é um de tipo de prática discursiva de caráter objetivo que circula na esfera acadêmica. Sua relevância se apresenta em relação ao que é dito e não a quem o diz (ADORNE, 2012, p. 45). Neste gênero discursivo, o especialista estabelece um processo de interlocução com o público profissional da cultura em que se insere, especialistas e semiespecialistas. Em relação aos textos acadêmicos coletados para a nossa pesquisa, estamos nos referindo a economistas, professores, pesquisadores e alunos da área de Economia.

Os artigos científicos apresentam os resultados de estudos completos de um determinado objeto de pesquisa, e são publicados em revistas ou periódicos especializados. De acordo com Costa (2011, p. 1), os artigos científicos distinguem-se dos diferentes tipos de trabalhos científicos, tais como a dissertação de mestrado e a tese de doutorado, pela sua reduzida dimensão e conteúdo. Servem para comunicar os resultados de pesquisas, ideias e debates de uma forma concisa. É um meio de comunicação e de intercâmbio de ideias entre cientistas da sua área de atuação.

\section{b) dissertações e teses}

A dissertação de mestrado e a tese de doutorado apresentam as mesmas características do artigo científico, mas seus propósitos são outros. O gênero textual dissertação é um "documento" que autoriza oficialmente o candidato a obter o título de mestre, ao passo que a tese o autoriza a alcançar o título de doutor.

De acordo com o documento NBR 14724 (2002) da Associação Brasileira de Normas Técnicas (ABNT), esses gêneros podem ser definidos como:

\footnotetext{
Dissertação - documento que representa o resultado de um trabalho experimental ou exposição de um estudo científico retrospectivo, de tema único e bem delimitado em sua extensão, com o objetivo de reunir, analisar e interpretar informações. Deve evidenciar o conhecimento de literatura existente sobre o assunto e a capacidade de sistematização do candidato. É feito sob a coordenação de um orientador (doutor), visando a obtenção do título de mestre.

Tese - documento que representa o resultado de um trabalho experimental ou exposição de um estudo científico retrospectivo de tema único e bem delimitado. Deve ser elaborado com base em investigação original, constituindo-se em real contribuição para a especialidade em questão. É feito sob a coordenação de um orientador (doutor) e visa a obtenção do título de doutor ou livre-docência.
} 
Segundo Moyano (2001, p. 5), os interlocutores desse processo de interação verbal são, consequentemente, pesquisadores, envolvendo docentes de graduação e de pósgraduação, por exemplo. A publicação realiza-se no âmbito da instituição em que o texto se origina, cuja circulação é bastante reduzida.

A seguir, propomos uma pequena escala dos gêneros discursivos científicos que fazem parte deste estudo. Ainda que todos sejam especializados, podemos pensar em uma gradação conforme a proposta por Ciapuscio (2008, p. 35):

\begin{tabular}{|l|l|}
\hline + especializado & tese e dissertação \\
\hline - especializado & artigo \\
\hline
\end{tabular}

De acordo com a tabela acima, observamos que a dissertação de mestrado e a tese de doutorado são mais especializadas, ao passo que o artigo aparece em uma gradação um pouco abaixo deles. Contudo, torna-se necessário comentar que essa pequena gradação não implica em diferentes vieses cognitivos empregados na denominação metafórica dos termos da Economia, de forma que sua funcionalidade será a mesma para diversos contextos desse tipo de comunicação.

\subsection{Constituição dos corpora}

Para que o corpus desta pesquisa fosse constituído e processado, em primeiro lugar, definimos o período de publicação dos textos científicos da área de Economia a serem estudados - no caso, os datados de 2005 a 2015 -, a fim de que pudéssemos realizar o estudo por meio de dados atualizados nos últimos 10 anos. Não incluímos o período de 2016, pois o projeto de pesquisa desse estudo data do ano de 2015, período em que estivemos participando do concurso de admissão para o curso de doutoramento. Em segundo lugar, decidimos estudar a produção científica em Economia a partir das bases de dados da Universidade de São Paulo (USP) e da Universidade Estadual de Campinas (Unicamp), visto que, de acordo com a agência FAPESP, elas representam as principais instituições do país em publicação de artigos, e, também, pelas suas posições ocupadas no ranking de principais faculdades de Economia do Brasil. 
Em relação aos artigos científicos publicados por essas instituições, faremos a seguir uma descrição de duas revistas divulgadas pela USP e três pela Unicamp, baseando-nos nas apresentações encontradas na capa de cada uma delas.

$\mathrm{Na}$ USP, as revistas pesquisadas foram a Estudos Econômicos, ${ }^{34}$ focada na publicação de trabalhos inéditos em todas as áreas da Economia, com autoria de pesquisadores brasileiros e estrangeiros; e Economia Aplicada, ${ }^{35}$ a qual, de acordo com sua apresentação, divulga trabalhos de análise econômica aplicados a problemas específicos, tanto de interesse do setor público quanto do privado, contendo estudos quantitativos cujos resultados possam aproximar a teoria da realidade.

$\mathrm{Na}$ Unicamp, foram pesquisadas três revistas: ${ }^{36}$ Economia e sociedade, que se ocupa em debater e divulgar temas relacionados ao pensamento econômico e às questões sociais e políticas brasileiras, cujos artigos são escritos por economistas e cientistas sociais; Formação econômica, que tem por objetivo apresentar artigos escritos por alunos da graduação; e Leituras de economia política, revista gerida pelos alunos da pósgraduação do Instituto de Economia cujo escopo é o de servir de instrumento de aprendizagem e de troca de experiências entre os "mestrandos" e "doutorandos". Ela também publica a produção científica de outros centros de ensino de pós-graduação do país com o objetivo de promover debates e contribuições para o avanço da ciência econômica no Brasil.

Sendo assim, decidimos realizar a coleta do corpus constituído por teses de doutoramento, dissertações de mestrado e artigos científicos a partir dessas publicações já digitalizadas pela USP e pela Unicamp. Na fase inicial do projeto, havíamos pensado em coletar também o corpus semiespecializado (textos redigidos por especialistas com um caráter de vulgarização da ciência), e os de divulgação científica, ou seja, dirigidos a um público leigo. Contudo, esses dois últimos meios foram eliminados, uma vez que nosso objetivo era estudar o processamento de metáforas por meio de textos especializados, garantindo assim o rigor da pesquisa no campo científico.

Depois da recolha do corpus, foi realizada a conversão dos textos em formato eletrônico (TXT); consecutivamente a essa etapa e com o auxílio de um programador Dr. José Lopes Moreira Filho -, o corpus foi etiquetado por meio do programa TreeTagger; em seguida, foi realizada a frequência da contagem das palavras (unigramas,

\footnotetext{
${ }^{34}$ Disponível em: <http://www.revistas.usp.br/ee/>.

${ }^{35}$ Disponível em: <http://www.revistas.usp.br/ecoa $>$.

${ }^{36}$ Disponível em: <http://www3.eco.unicamp.br/publicacoes>.
} 
bigramas, trigramas e quadrigramas) com o uso de rotinas (conjunto de instrução capaz de executar uma tarefa) em Python (linguagem de programação que apresenta uma série de bibliotecas disponíveis para o processamento de dados). Por último, foi contratado um local para hospedagem de site a fim de que os dados do corpus e as interfaces de busca fossem armazenados. Tal procedimento ofereceu um ambiente propício para as demais etapas da pesquisa.

O uso de recursos computacionais por intermédio de programação na linguagem Python deve-se às necessidades da pesquisa, uma vez que o corpus de estudo apresenta milhões de palavras. Recursos criados de forma específica por essa linguagem para os propósitos deste estudo contribuíram para melhores resultados (maior precisão), e menor esforço em relação a questões computacionais, cujo objetivo é o de facilitar a nossa concentração nas análises linguísticas.

Podemos, de forma geral, sistematizar as etapas da organização e processamento do corpus da seguinte forma:

1. download de arquivos PDF de sites da Internet;

2. conversão dos arquivos PDF em arquivos TXT;

3. ajustagem da conversão por meio de programas escritos em linguagem Python (palavras separadas com hífen pela formatação em PDF e conversão de codificação);

4. etiquetagem morfológica do corpus por meio do etiquetador TreeTagger;

5. contagem da frequência das palavras do corpus por meio de programas escritos em linguagem Python;

6. formatação dos dados de frequência de listas de palavras (unigramas, bigramas, trigramas e quadrigramas) e aplicação de filtros em planilhas do Microsoft Excel para facilitar a seleção de termos metafóricos;

7. criação de site para armazenamento dos dados do corpus em interfaces de busca. 


\subsection{Coleta do corpus}

Registro acadêmico: artigos, dissertações e teses (USP e UNICAMP).

Período: 2005 a 2015.

Em relação à coleta do corpus citado acima, registramos um total de 1.066 arquivos, dentre os quais 818 são artigos e 248 são dissertações de mestrado e teses de doutoramento. Vejamos a seguir a descrição do número de arquivos, itens (tokens palavras repetidas), formas (types - palavras não repetidas), razão forma/item (type token ratio) e a porcentagem de vocábulos que ocorrem no corpus dividindo-se o número total de formas pelo número total de itens nos dados gerais do corpus.

No tópico anterior, sobre as características dos corpora, analisamos alguns dados sobre os arquivos das dissertações, teses e arquivos, tais como números relativos a itens (tokens), formas (types) e razão forma/item (type token ratio); na tabela descrita acima sobre os dados gerais do corpus, observamos pela razão forma/item 1,75\% que há pouca diversidade de vocábulos, o que é natural pelo fato de se tratar de um corpus especializado.

Para o cálculo dos dados gerais do corpus, ${ }^{37}$ uma rotina (conjunto de instruções capaz de executar uma tarefa) escrita em Python foi utilizada após a sua etiquetagem. $\mathrm{O}$ algoritmo da rotina é descrito abaixo:

1. Instancia um contador;

2. Define o caminho dos arquivos do corpus;

3. Faz a leitura de cada arquivo linha por linha em um comando de laço;

4. Separa os campos em cada linha pelo caractere de tabulação 'tt', identificando palavra, etiqueta e lema;

5. Passa o valor do primeiro campo (palavra) para o contador na contagem;

6. Utiliza os dados do contador para calcular o número de token, types e hápax do corpus.

\footnotetext{
${ }^{37}$ Os números dos dados gerais do corpus podem variar de acordo com o tipo de ferramenta, script ou condições utilizadas para as contagens. Neste caso, leva-se em consideração a itemização (quebra do texto em unidades - separam-se palavras e pontuação) do TreeTagger.
} 
Em forma de tabela, demonstraremos alguns dados que caracterizam este corpus do ponto de vista do número de arquivos, itens (tokens) e formas (types):

\section{Dissertações e teses}

\begin{tabular}{|l|c|}
\hline Arquivos & 248 \\
\hline Itens (tokens) & 17.426 .511 \\
\hline Formas (types) & 326.606 \\
\hline Razão forma/item (type token ratio) & 1,87 \\
\hline
\end{tabular}

\section{Artigos}

\begin{tabular}{|l|c|}
\hline Arquivos & 818 \\
\hline Itens (tokens) & 10.664 .044 \\
\hline Formas (types) & 269.216 \\
\hline Razão forma/item (type token ratio) & 2,52 \\
\hline
\end{tabular}

\section{Dados gerais do corpus}

\begin{tabular}{|l|c|}
\hline Arquivos & 1.066 \\
\hline Itens (tokens) & 28.090 .555 \\
\hline Formas (types) & 491.339 \\
\hline Razão forma/item (type token ratio) & 1,75 \\
\hline
\end{tabular}

De acordo com os dados apresentados nas tabelas acima, podemos chegar à conclusão de que o número de dados coletados é representativo para a pesquisa. Conforme Berber Sardinha (2004, p. 147), um corpus que tenha mais de 100.000 palavras é suficiente para abarcar uma variação de categorias de palavras para esse tipo de análise. A razão forma/item (type token ratio) - medida utilizada para cálculo da riqueza lexical - também revela dados interessantes a respeito desse valor, pois essa razão é sensível ao tamanho do corpus; quanto maior o seu tamanho, menor será o seu valor expresso por 
essa razão. No caso das dissertações e das teses, o resultado foi de 1,87; para os artigos, 2,52 .

Notamos também que há um número maior de artigos (o quádruplo) em relação ao número de teses e dissertações, dada a complexidade da produção acadêmica desses dois últimos gêneros. O número de tokens dos artigos é menor do que o das dissertações e das teses, uma vez que os artigos têm um número menor de páginas.

Consideramos também importante abordar o grau de especialização em relação às características do corpus estudado neste trabalho, uma vez que os gêneros que constituem os textos prospectados apresentam pequenas diferenças quanto aos graus de especialização. Conforme Ciapuscio (2008, p. 35), há textos mais especializados e menos especializados em uma escala que engloba, respectivamente, o manual técnico (mais especializado), o artigo de semidivulgação, a enciclopédia e a imprensa escrita (menos especializado). A autora apresenta ainda uma tipologia de cinco estilos científicos, os quais já foram explicados na Parte I (Capítulo 2) desta tese.

\subsection{O processamento dos corpora}

\subsubsection{Preparação dos textos para a formação do corpus de estudo}

Após a coleta das teses, dissertações e artigos nos sites da USP e da Unicamp, foi necessária a conversão dos arquivos originalmente em formato PDF (Portable Document Format) para TXT (texto sem formatação) para o processamento computacional dos textos.

Para tanto, foi utilizado o programa Xpdf, disponível no site http://www.foolabs.com/xpdf/, que apresenta recursos gratuitos para visualização, leitura e escrita de arquivos PDF, os quais podem ser acessados também por diferentes linguagens de programação para a conversão de arquivos PDF para TXT.

Desse modo, o programa Xpdf foi baixado e instalado em um computador com sistema operacional Linux, distribuição Ubuntu. Em seguida, criou-se um script em Shell ${ }^{38}$ para automatizar a conversão dos 1.066 arquivos do corpus. A conversão foi realizada pelo comando 'sh pdt2txt.sh < pasta do corpus >' em um terminal interpretador

\footnotetext{
${ }^{38}$ Linguagem de script utilizada na maioria das distribuições GNU/Linux.
} 
de linhas de comando. A seguir, a título de ilustração, fornecemos abaixo um exemplo da tela gerada pelo script criado para essa primeira parte do processamento:

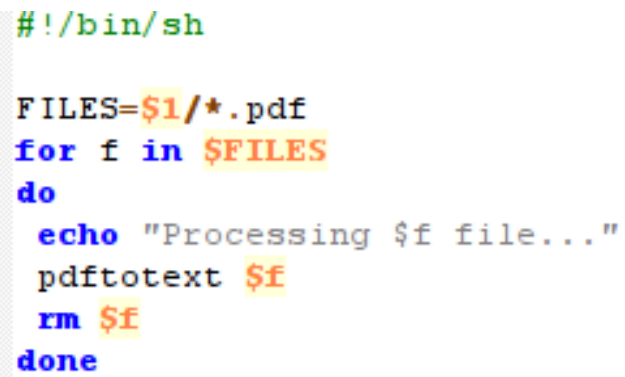

Figura 5 - Shell script para automatizar a etiquetagem dos arquivos do corpus.

O script faz a leitura de cada arquivo na pasta do corpus (local passado como argumento na linha de comando), realiza a conversão do formato PDF para TXT por meio do comando pdftotext do Xpdf, que remove o arquivo PDF original, restando apenas os arquivos já convertidos.

\subsubsection{Etiquetagem do corpus de estudo}

Para a etiquetagem do corpus, foi utilizado o etiquetador TreeTagger (ferramenta para anotação de textos em diferentes línguas desenvolvida pelo Instituto de Linguística Computacional da Universidade de Stuttgart), disponível gratuitamente para pesquisa. A anotação consiste em categorizar as palavras em classes ou categorias morfossintáticas e em fornecer informação sobre a lematização a partir de um léxico e de um corpus de treinamento previamente etiquetado (arquivos de parâmetros), sendo amplamente adaptável a outras línguas.

O TreeTagger encontra-se disponível no endereço http://www.cis.unimuenchen.de/ schmid/tools/TreeTagger/, juntamente com instruções de uso e uma série de recursos linguísticos para etiquetagem de diversas línguas (inglês, francês, italiano, português, entre outras), e a descrição do conjunto de etiquetas dos recursos disponíveis. Para a etiquetagem, foi realizado o download e a instalação do etiquetador TreeTagger em uma máquina com sistema operacional Linux, distribuição Ubuntu, uma vez que tal sistema permite maior facilidade para a execução do programa. 
Como recurso linguístico para a etiquetagem do português, foi utilizado o arquivo de parâmetros aprimorado e fornecido por Pablo Gamallo, ${ }^{39}$ também disponível na mesma página do etiquetador TreeTagger. A descrição do conjunto de etiquetas utilizado na etiquetagem encontra-se disponível no endereço: http://www.cis.unimuenchen.de/ schmid/tools/TreeTagger/data/Portuguese-Tagset.html.

As etiquetas são compostas por letras maiúsculas e números. A primeira letra da etiqueta indica a categoria. Os demais caracteres indicam outras propriedades como: tipo, pessoa, gênero, número, grau, entre outras. Por exemplo, a palavra 'dividendos' pode receber a etiqueta 'NCMP', que indica: $\mathrm{N}$ = categoria/nome; $\mathrm{C}=$ tipo/comum; $\mathrm{M}=$ gênero/masculino; $\mathrm{P}=$ número/plural.

O quadro a seguir contém as principais categorias do conjunto utilizado:

$\begin{array}{ll}\text { Código } & \text { Valor } \\ \text { A } & \text { Adjetivo } \\ \text { R } & \text { Advérbio } \\ \text { D } & \text { Determinante } \\ \text { N } & \text { Nome } \\ \text { V } & \text { Verbo } \\ \text { P } & \text { Pronome } \\ \text { C } & \text { Conjunção } \\ \text { I } & \text { Interjeição } \\ \text { S } & \text { Preposição } \\ \text { F } & \text { Pontuação } \\ Z & \text { Cifra }\end{array}$

Para o processo de etiquetagem dos arquivos do corpus, após a instalação e configuração do TreeTagger, criou-se um script em Shell ('tree_tagger.sh') para automatizar a etiquetagem de cada arquivo pelo comando 'sh tree_tagger.sh < pasta do corpus ${ }^{>}$' em um terminal interpretador de linha de comando. A seguir, o exemplo da tela em que aparece essa informação:

\footnotetext{
${ }^{39}$ Pablo Gamallo é pesquisador do ProLNat@GE do grupo de estudos de Processamento de Linguagem
} Natural e professor da Universidade de Santiago de Compostela de Linguística Aplicada. 


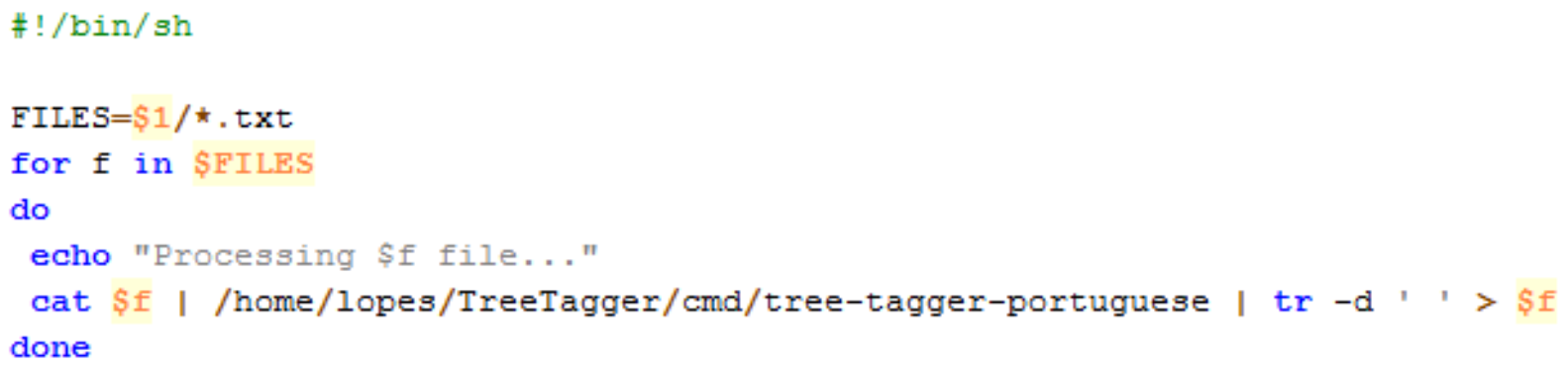

Figura 6 - Shell script para automatizar a etiquetagem dos arquivos do corpus.

O script faz a leitura de cada arquivo na pasta do corpus (local passado como argumento na linha de comando), realiza a etiquetagem por meio do comando 'treetagger-portuguese' do TreeTagger, que subescreve o mesmo arquivo com o conteúdo etiquetado.

Ao final do processamento, cada arquivo do corpus foi etiquetado e salvo na mesma pasta (uma cópia dos arquivos originais foi mantida antes do processamento). Conforme os resultados do processamento, os textos etiquetados nos arquivos apresentaram uma formatação padronizada específica que permitiu facilitar a manipulação computacional para análises posteriores. A formação foi realizada de forma que cada item/token (palavra, pontuação ou símbolo) fosse separado por um caractere de nova linha ('In') e os campos etiqueta e lema fossem separados pelo caractere de tabulação ('ไt'). Vejamos a ilustração a seguir:

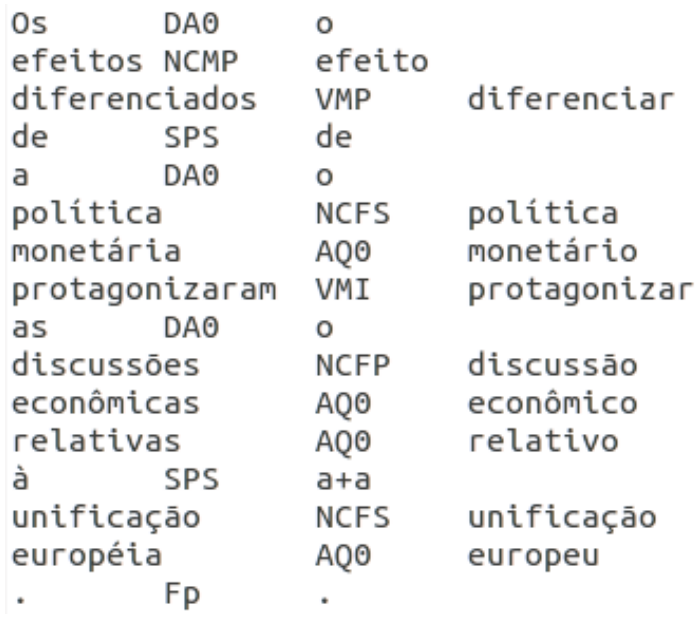

Figura 7 - Exemplo de frase etiquetada em um dos arquivos do corpus.

É importante salientar que o etiquetador TreeTagger já realiza a itemização (quebra do texto em unidades) das palavras do corpus durante a etiquetagem. Portanto, o 
corpus de estudo etiquetado foi segmentado de acordo com as regras de itemização do programa, conforme o arquivo de parâmetros utilizados. Todo o processamento posterior considera tal segmentação realizada.

\subsubsection{Criação de tabela de unigramas com filtros para manipulação de dados}

Tendo em vista o tamanho do corpus coletado, que ultrapassa a quantidade de milhões de palavras, foi necessário realizar um conjunto de procedimentos de processamento dos dados que facilitasse a seleção de candidatos para a identificação de termos, que consistiu em limitar a quantidade de dados a serem estudados por meio da eliminação de itens-candidatos considerados pouco ou não produtivos para a pesquisa. A aproximação dos itens-candidatos considerados mais relevantes foi realizada a partir da criação de filtros e ordenação dos dados.

Conforme já dissemos anteriormente, o processamento dos dados do corpus foi realizado a partir da criação e execução de códigos em linguagem de programação, uma vez que as necessidades da pesquisa mostraram-se específicas a um processo que poderia ser mais bem executado a partir de programas criados diretamente para o fim pretendido do que pela tentativa de combinação de ferramentas genéricas de processamento.

Para realizar o processamento das palavras do corpus de estudo, uma vez já etiquetado pela ferramenta TreeTagger, utilizou-se a linguagem Python (versão 3.6 distribuição Anaconda ${ }^{40}$ para a criação de scripts a fim de automatizar as tarefas e gerar listas de frequência e outros dados requeridos para a pesquisa.

Para a escrita e execução de rotinas em Python, utilizou-se como IDE (Integrated Development Environment) o programa Eclipse. O Eclipse é um IDE gratuito para desenvolvimento Java que suporta diversas outras linguagens por meio de plug-ins (extensões de módulos para o programa). Para a linguagem Python, foi utilizado o plugin Pydev. As vantagens de uso de um IDE como o Eclipse estão relacionadas à organização de projetos, complementação e identificação automática do código, além de fácil execução e retorno de mensagens de aviso ou erros.

\footnotetext{
${ }^{40}$ A distribuição Anaconda para a linguagem Python fornece uma plataforma gratuita com a maioria das bibliotecas mais populares especializadas para a realização de pesquisas científicas com base em dados, tal como a biblioteca do Natural Language Toolkit (NLTK) para o processamento de línguas naturais.
} 
No processamento do corpus, fizemos uso também de outros corpora e recursos linguísticos disponíveis a fim de facilitar nossa análise. Eles aparecem descritos a seguir:

- Stoplist de língua portuguesa do NLTK (Natural Language Toolkit): recurso linguístico disponível na própria biblioteca do NLTK;

- Stoplist de língua inglesa do NLTK (Natural Language Toolkit): recurso linguístico disponível na própria biblioteca do NLTK;

- Lista de frequência do corpus brasileiro: lista do projeto de um corpus de um bilhão de palavras do português brasileiro contemporâneo, disponível em http://corpusbrasileiro.pucsp.br/cb/Acesso.html;

- Lista de palavras do dicionário br.ispell: lista de palavras do português do Brasil, disponível em https://www.ime.usp.br/ ueda/br.ispell;

- Lista de palavras do dicionário do Mozilla Firefox: lista de palavras do português do Brasil, disponível em https://addons.mozilla.org/en-US/firefox/languagetools;

- Lista de palavras do Corpus BNC (British National Corpus): lista de um corpus de mais de 100 milhões de palavras do inglês britânico composto por diversos gêneros, disponível em https://www.kilgarriff.co.uk/bnc-readme.html;

- Termos metafóricos encontrados em outras pesquisas: lista de metáforas que foram coletadas por meio da nossa dissertação de mestrado e do Dicionário de Economia do século XXI, de Sandroni.

O esquema a seguir resume o processamento realizado para a criação de uma tabela para filtragem de palavras candidatas a termos da Economia: 


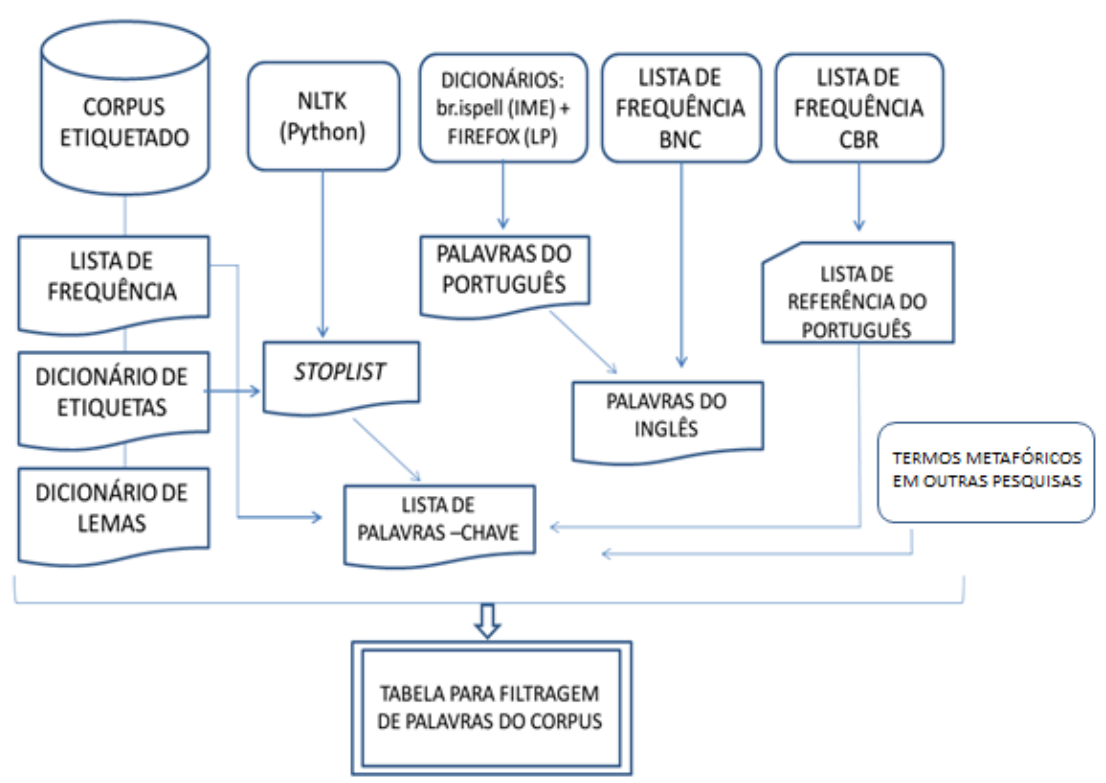

Figura 8 - Esquema de processamento para criação de tabela de filtragem.

Conforme demonstra a figura acima, o processo obedeceu à criação de dados em uma ordem específica. Descrevemos os principais processos para a composição dos dados da tabela de unigramas com filtros para a manipulação de dados.

\subsubsection{Lista de frequência das palavras do corpus}

A contagem das palavras foi feita a partir da itemização gerada pela etiquetagem realizada pelo etiquetador TreeTagger. A rotina implementada em Python é descrita pelo seguinte algoritmo:

1. Instancia um contador;

2. Define o caminho dos arquivos do corpus;

3. Faz a leitura de cada arquivo linha por linha em um comando de laço;

4. Separa os campos em cada linha pelo caractere de tabulação 'It', identificando palavra, etiqueta e lema;

5. Passa o valor do primeiro campo (palavra), convertido para caixa baixa, para o contador na contagem;

6. Utiliza os dados do contador para calcular o número de token, types e hápax do corpus.

7. Converte os dados do contador em uma lista para armazenar em arquivo. 


\subsubsection{Dicionário de palavras e etiquetas mais frequentes}

A criação de um dicionário de palavras e etiquetas mais frequentes foi realizada a partir do seguinte algoritmo:

1. Instancia um contador;

2. Define o caminho dos arquivos do corpus;

3. Faz a leitura de cada arquivo linha por linha em um comando de laço;

4. Separa os campos em cada linha pelo caractere de tabulação 'It', identificando palavra, etiqueta e lema;

5. Aplica uma condição para evitar pontuação e caracteres não formadores de palavras;

6. Passa o valor do primeiro campo (palavra), convertido para caixa baixa, e do segundo campo (etiqueta) para uma tupla (em linguagem Python, tupla corresponde a uma lista de dados) para o contador na contagem;

7. Converte os dados do contador em uma lista para armazenar em arquivo.

\subsubsection{Dicionário de palavras e lemas mais frequentes}

A criação de um dicionário de palavras e lemas foi realizada a partir do seguinte algoritmo:

1. Instancia um contador;

2. Define o caminho dos arquivos do corpus;

3. Faz a leitura de cada arquivo linha por linha em um comando de laço;

4. Separa os campos em cada linha pelo caractere de tabulação ' $\mid t$ ', identificando palavra, etiqueta e lema;

5. Aplica uma condição para evitar pontuação e caracteres não formadores de palavras;

6. Passa o valor do primeiro campo (palavra), convertido para caixa baixa, e do segundo campo (etiqueta) para uma tupla para o contador na contagem;

\subsubsection{Lista de frequência das palavras em arquivos do corpus}

A criação de uma lista de frequência das palavras em arquivos do corpus foi realizada conforme o seguinte algoritmo: 
1. Faz a leitura da lista de frequência do corpus de estudo e armazena em um dicionário para contagem geral;

2. Define o caminho dos arquivos do corpus de estudo;

3. Faz a leitura de cada arquivo, instanciando um contador, em um laço de repetição;

4. Faz a leitura linha por linha do arquivo em um laço de repetição;

5. Separa os campos em cada linha pelo caractere de tabulação ' $\mid t$ ', identificando palavra, etiqueta e lema;

6. Aplica uma condição para evitar pontuação e caracteres não formadores de palavras;

6. Passa o valor do primeiro campo (palavra), convertido para caixa baixa, para o contador na contagem de palavras do arquivo;

7. Atualiza as frequências no dicionário de contagem geral a partir do contador; 8. Converte os dados do dicionário de contagem geral em uma lista para armazenar em arquivo ao final do laço de repetição.

\subsubsection{Lista de palavras inglesas}

Foi útil para este trabalho gerar uma lista de palavras inglesas para a identificação e exclusão de palavras oriundas desse idioma. A lista de palavras do corpus BNC foi utilizada para esse propósito.

Para tanto, optou-se por uma solução heurística implementada em Python conforme a descrição do seguinte algoritmo:

1. Faz a leitura da lista de frequência do BNC a partir de um arquivo;

2. Exclui as palavras com frequência menor que 100 para diminuir a possibilidade de incluir palavras não inglesas;

3. Faz a leitura de uma lista de palavras de língua portuguesa em arquivo;

4. Exclui as palavras da lista de frequência do BNC que estejam na lista de palavras de língua portuguesa;

5. Converte a lista de frequência do BNC filtrada em uma lista simples para armazenamento em arquivo.

Após o processamento, foi realizada uma inspeção manual nas palavras excluídas para que não houvesse perda de possíveis candidatos produtivos para a pesquisa. 


\subsubsection{Lista de palavras-chave do corpus de estudo}

Para extrair palavras-chave do corpus de estudo, ${ }^{41}$ foi necessária a comparação da lista de frequência do corpus de estudo com a lista de frequência de um corpus de referência maior que aquele.

Nesse caso, foi utilizada a lista de frequência formatada do corpus brasileiro como lista de referência, conforme descrito em seção anterior. A comparação foi feita por meio do uso da função estatística log-likelihood, geralmente utilizada para tal fim em programas de análise e exploração de corpora.

Para a utilização da função na comparação, foi criado um módulo que implementa a função em Python a partir da descrição e exemplos disponibilizados por Rayson e Garside (2000) em uma calculadora on-line (Log-likelihood and effect size calculator). No módulo criado, as variáveis para o cálculo na função são:

1. frequência da palavra no corpus de estudo;

2. frequência da palavra no corpus de referência;

3. número total de itens no corpus de estudo;

4. número total de itens no corpus de referência.

Para a implementação do código em Python, o qual calcula o valor de loglikelihood para cada palavra do corpus de estudo em comparação com a lista de frequência do corpus brasileiro (corpus de referência), foi utilizado o seguinte algoritmo:

1. Define o número total de tokens do corpus de estudo e do corpus de referência;

2. Carrega a lista de frequência do corpus de estudo e a lista de frequência do corpus de referência;

3. Junta os dados das listas em uma única tabela, usando a palavra como um índice;

4. Filtra as palavras por meio de uma stoplist do português;

5. Cria uma lista para armazenar resultados;

6. Calcula o valor de log-likelihood para cada palavra da tabela, em um laço de repetição, passando os argumentos para a função 'll';

7. Adiciona a palavra e o valor de log-likelihood na lista criada;

8. Classifica os dados da lista por valor de log-likelihood, em ordem decrescente, ao término do laço de repetição;

9. Converte os dados da lista resultante para armazenar em arquivo.

\footnotetext{
${ }^{41} \mathrm{O}$ processo de extração de palavras-chave tem o objetivo de identificar as palavras que mais caracterizam o corpus de estudo por meio da comparação estatística com um corpus de referência.
} 
As palavras do corpus de estudo que possuem uma frequência relativa maior em relação às frequências do corpus de referência recebem um valor de log-likelihood maior. O de log-likelihood é considerado um indicador do grau de "chavicidade" da palavra. A tabela a seguir apresenta as 25 primeiras palavras-chave do corpus de estudo:

\begin{tabular}{|c|c|c|}
\hline $\mathrm{N}$ & PALAVRA & CHAVICIDADE \\
\hline 1 & economia & 114222,31 \\
\hline 2 & capital & 72640,67 \\
\hline 3 & crescimento & 67963,87 \\
\hline 4 & tabela & 64544,29 \\
\hline 5 & desenvolvimento & 61939,98 \\
\hline 6 & folha & 58908,50 \\
\hline 7 & taxa & 50913,11 \\
\hline 8 & renda & 46058,61 \\
\hline 9 & dia & 44876,44 \\
\hline 10 & modelo & 44665,65 \\
\hline 11 & produção & 41975,31 \\
\hline 12 & paises & 40703,73 \\
\hline 13 & análise & 40351,27 \\
\hline 14 & demanda & 37922,37 \\
\hline 15 & econômico & 33559,43 \\
\hline 16 & trabalho & 32279,79 \\
\hline 17 & investimento & 32032,39 \\
\hline 18 & mercado & 31534,06 \\
\hline 19 & políticas & 30464,39 \\
\hline 20 & industrial & 29468,28 \\
\hline 21 & fonte & 29176,02 \\
\hline 22 & ativos & 29167,67 \\
\hline 23 & econômica & 27184,78 \\
\hline 24 & firmas & 26956,71 \\
\hline 25 & crédito & 26467,00 \\
\hline
\end{tabular}

Figura 9 - As 25 primeiras palavras-chave do corpus de estudo

\subsubsection{Lista de termos metafóricos encontrados em outras pesquisas}

Para auxiliar na análise de termos metafóricos, criou-se uma lista simples em arquivo com termos metafóricos encontrados em outras pesquisas. A lista, cuja ilustração aparece no quadro a seguir, inclui metáforas que foram coletadas por meio da nossa dissertação de mestrado e do Dicionário de Economia do século XXI, de Sandroni. Nenhum processamento especial foi realizado com essa lista. 


\begin{tabular}{|c|c|c|c|}
\hline $\mathrm{N}$ & PALAVRA & $\mathrm{N}$ & PALAVRA \\
\hline 1 & capital & 13 & baixo \\
\hline 2 & ativo & 14 & emergente \\
\hline 3 & fluxo & 15 & carteira \\
\hline 4 & liquidez & 16 & ação \\
\hline 5 & jogo & 17 & flutuação \\
\hline 6 & crise & 18 & bolsa \\
\hline 7 & volatilidade & 19 & desaceleração \\
\hline 8 & papel & 20 & tesouro \\
\hline 9 & choque & 21 & choque \\
\hline 10 & passivo & 22 & papel \\
\hline 11 & elasticidade & 23 & pico \\
\hline 12 & flutuação & 24 & piso \\
\hline
\end{tabular}

Figura 10 - Exemplos de termos metafóricos encontrados em outras pesquisas.

Tendo realizado o processamento para a geração de dados para a composição de filtros, o próximo passo foi a junção de todos os dados em uma única tabela de unigramas para filtragem e análise do pesquisador.

\subsubsection{Combinação dos dados em uma única tabela de unigramas para filtragem}

Para combinar todos os dados processados em uma única tabela para filtragem, foi criada uma rotina em Python que basicamente abre cada arquivo e adiciona os dados a uma estrutura de dados semelhantes a uma tabela, conforme a relação de um índice (palavra). Após a junção, os dados são convertidos para uma tabela em um arquivo do Microsoft Excel. A tabela gerada incluiu 11 colunas, na seguinte ordem:

1. palavra;

2. frequência da palavra;

3. porcentagem da frequência;

4. frequência da palavra nos arquivos do corpus;

5. porcentagem da frequência da palavra nos arquivos do corpus;

6. valor de chavicidade;

7. valor de chavicidade multiplicado pela frequência da palavra nos arquivos do corpus;

8. indicativo de palavra da língua inglesa;

9. etiqueta morfológica mais frequente;

10. lema da palavra;

11. indicativo de possível metáfora a partir de termos de outras pesquisas. 
A figura a seguir ilustra a tabela de unigramas com filtros no Microsoft Excel para análise do pesquisador:

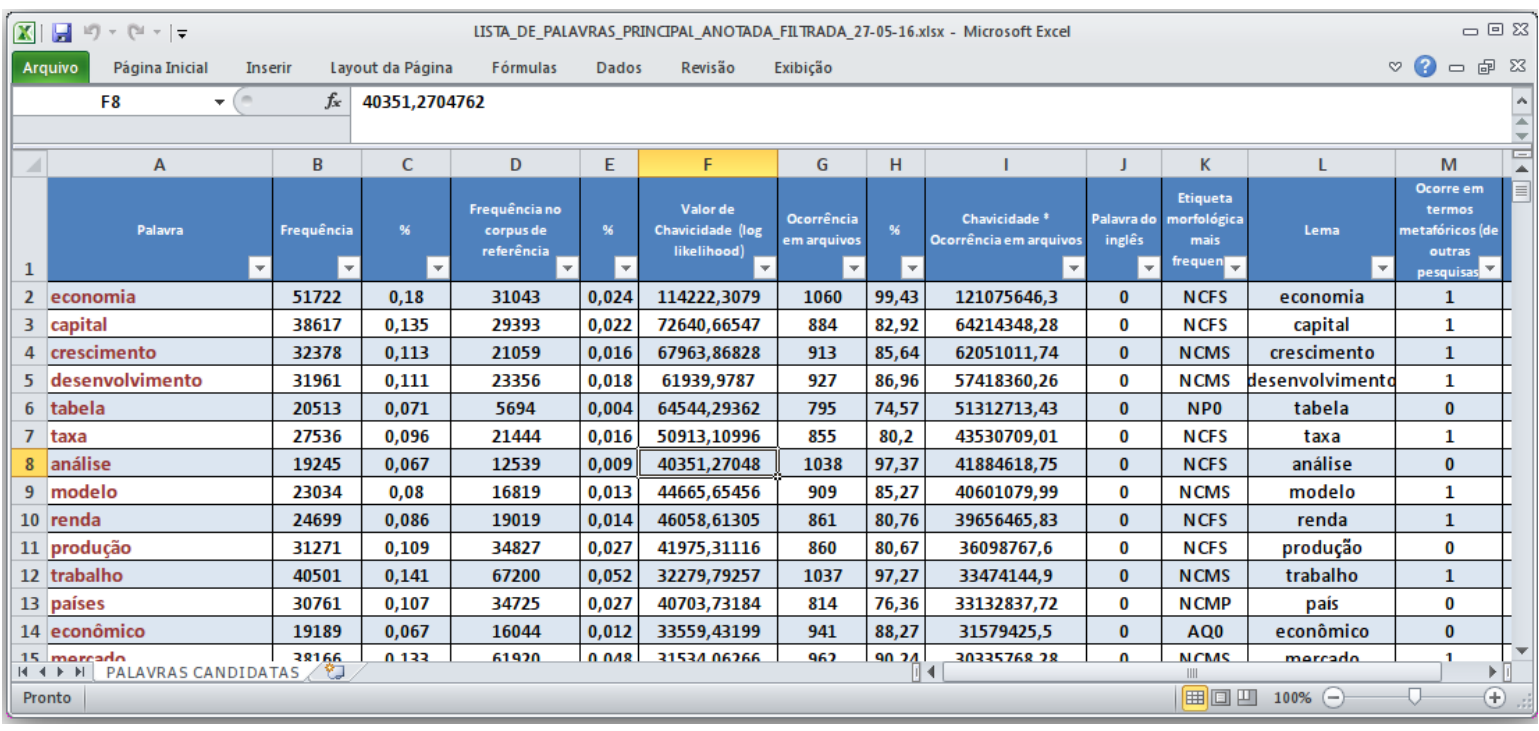

Figura 11 - Dados importados para a planilha do Microsoft Excel.

O próximo passo foi a definição da forma mais adequada para a ordenação da tabela, a fim de facilitar a nossa análise. Optou-se, então, por classificar os dados pela coluna com o valor de chavicidade multiplicado pela frequência da palavra, uma vez que esse método retornava o maior número de possíveis palavras metafóricas logo nas primeiras posições da lista, a partir da coluna de indicativo de possível metáfora levando em consideração os termos de outras pesquisas.

A próxima etapa foi a formatação da tabela no Microsoft Excel e a aplicação de filtros personalizados para diminuir o número de palavras a serem analisadas pelo pesquisador.

\subsubsection{Aplicação de filtros na tabela de unigramas para redução de dados para análise}

Após a formatação da tabela de "unigramas" no Microsoft Excel, decidiu-se aplicar uma combinação de filtros para diminuir o número de palavras a serem analisadas, eliminando possíveis palavras não produtivas, conforme os objetivos da pesquisa.

A seguir, veremos os filtros que foram criados pelo programa Python com o intuito de manipular os dados de corpora para prospectar termos: 
- o valor de chavicidade deve ser maior que 0 ;

- palavras inglesas são ignoradas (valor 1: uso de números binários para diferenciar do português que é igual a 0 );

- a palavra deve ocorrer em mais de $10 \%$ dos arquivos do corpus (esse número foi adotado a fim de que não aparecessem nas planilhas candidatos a termos que só ocorressem em um arquivo);

- as etiquetas morfológicas que iniciam com as letras a seguir são ignoradas:

$\circ \mathrm{Z}$ - cifras e numerais

○ D - determinantes

○ $\mathrm{P}$ - pronomes

○ $\mathrm{C}-$ conjunções

○ I - interjeições

○ $\mathrm{F}$ - pontuação

Após a aplicação dos filtros acima, restaram 2.600 formas para análise do pesquisador em relação aos "unigramas". Esse número de formas restantes corresponde a $0,52 \%$ do número total de formas para análise das palavras que podem ser candidatas a fazerem parte de termos metafóricos. Os dados foram ordenados pela coluna 'Chavicidade * Ocorrência em arquivos' para anotação na identificação de palavras candidatas.

\subsubsection{Procedimento de seleção de candidatos a termos em corpus especializado - referência}

Para que tivéssemos certeza de que os dados quantitativos estivessem adequados para o corpus de análise, consultamos uma pesquisa realizada por Silva e Teixeira (2010). Esses pesquisadores chegaram com seu corpus aos seguintes números de possíveis candidatos a termos, conforme a aplicação de cada ferramenta:

- $\quad 1.325$ palavras dos resultados do Corpógrafo;

- 4.298 vocábulos da lista de palavras-chave feitas com o programa Wordsmith tools; 
- 5.685 palavras do programa web e-Termos;

- 3.465 palavras do programa ZExtractor.

Em média, foram retornados 3.693 candidatos dentro de uma faixa entre 1.325 (menor) a 5.685 (maior). Levando em consideração os dados acima apresentados, nesta pesquisa foram aplicados filtros que resultam em um número próximo da média de candidatos retornados por essas ferramentas avaliadas por Silva e Teixeira (2010).

\subsubsection{Criação de listas de bigramas, trigramas e quadrigramas}

A criação de listas de $n$-gramas (bigramas, trigramas e quadrigramas) foi realizada após uma primeira análise da lista de unigramas para que a seleção de candidatos a termos fosse utilizada como condição de restrição para a massiva quantidade de $n$-gramas.

Para tanto, foram utilizadas duas rotinas independentes em Python. A primeira gera uma lista de todos os n-gramas do corpus, conforme o número específico de palavras (duas, três ou quatro). A segunda rotina realiza a aplicação de filtros para diminuir o número de registros a serem analisados por nós.

A fim de diminuir o número de n-gramas para análise, foram aplicadas as seguintes condições como filtros:

- o n-grama deve possuir frequência maior que 7. Esse número foi adotado com o objetivo de diminuir o número de itens a serem analisados; se esse critério não fosse usado, o número de possíveis candidatos a termo seria muito alto, o que dificultaria a nossa tarefa de triagem - tal critério também foi adotado por Silva e Teixeira (2010);

- as palavras do n-grama não podem apresentar números ou pontuação (exceto hífen);

- uma das palavras do n-grama deve estar na lista de possíveis candidatos a termos metafóricos selecionados por nós;

- determinadas posições de palavras do n-grama (p. ex., palavra 1 de um bigrama) não devem estar na stoplist;

- determinadas posições de palavras do n-grama devem possuir tamanho em caracteres maior que 1 . 
As condições foram adaptadas conforme o tipo de n-grama a ser avaliado (bigrama, trigrama ou quadrigrama). Para a filtragem da lista de trigramas e quadrigramas, por exemplo, modificamos as posições no termo em que o conjunto de regras seria mais efetivo. Assim, em trigramas não seria viável a aplicação de restrição de palavras gramaticais na posição w2 (segunda palavra do termo), uma vez que poderia excluir termos como "fluxo de caixa".

Desse modo, após a geração e filtragem das listas de n-gramas, os dados foram importados para o Microsoft Excel (um arquivo para cada tipo de $n$-grama), passando-se em seguida à sua análise a fim de identificarmos os termos metafóricos de lexias complexas.

A figura a seguir mostra um exemplo de planilha ${ }^{42}$ utilizada para a análise dos bigramas:

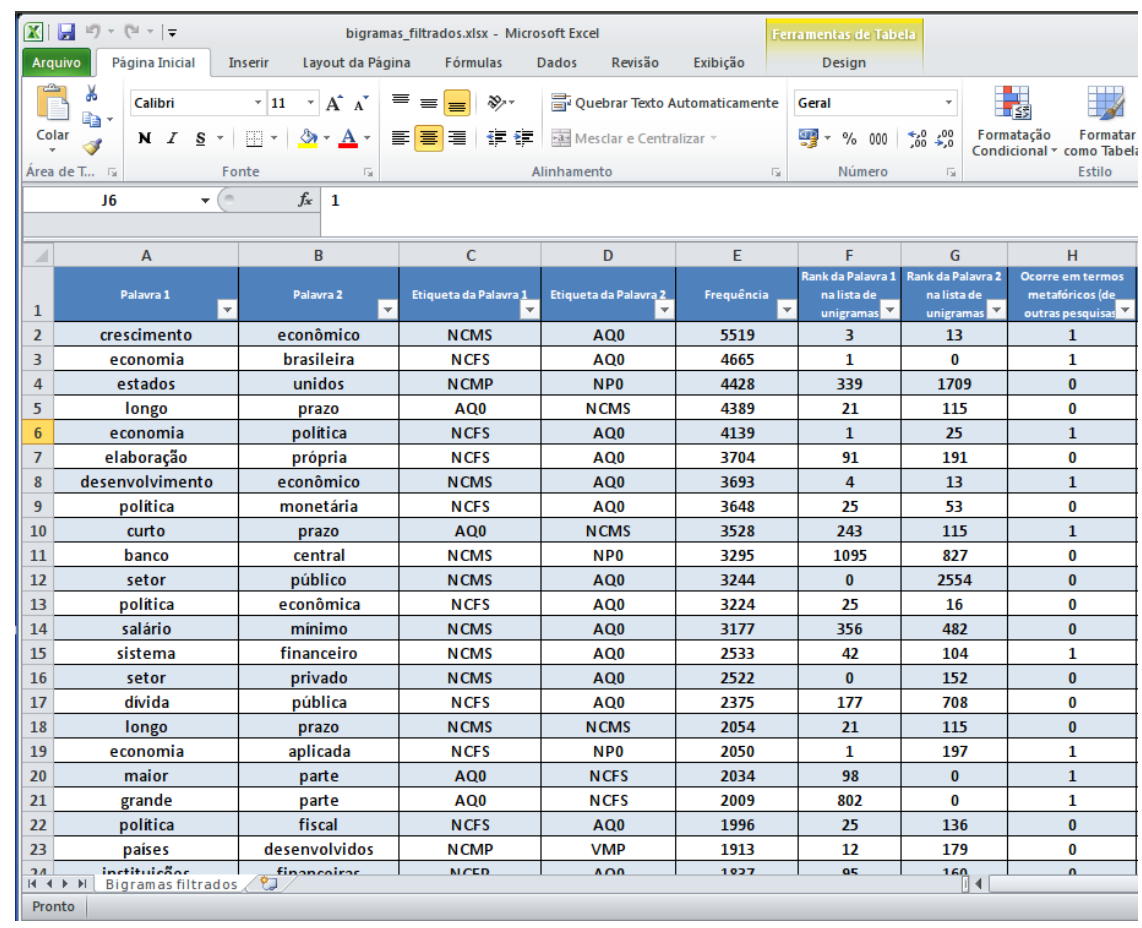

Figura 12 - Exemplo de planilha para análise de bigramas.

\subsubsection{Seleção de candidatos pelo pesquisador}

Após a geração das planilhas em Excel, foram obtidos os seguintes totais de registros (formas) dos n-gramas, a partir dos quais foi feita a seleção de candidatos a

\footnotetext{
${ }^{42} \mathrm{Na}$ planilha, dados de outros arquivos foram combinados para privilegiar nossa análise.
} 
termos e de candidatos a termos metafóricos da Economia: 491.778 unigramas, 3.814.203 bigramas, 10.429.043 trigramas e 16.983.178 quadrigramas. De posse desses dados, após a aplicação de filtros foram analisados 2.600 unigramas, 37.600 bigramas, 49.492 trigramas e 37.792 quadrigramas, cujos dados serão apresentados em forma de tabela mais à frente.

Por último, foi feita uma análise de contexto, ou seja, de concordâncias que se refere à listagem das ocorrências de uma palavra de busca de um corpus. Esta informação fica centralizada, com uma quantidade definida de contextos à esquerda e à direita para identificação de metáforas a partir dos termos selecionados das planilhas agrupadas em lexias simples (unigramas) e complexas (bigramas, trigramas e quadrigramas), conforme modelo apresentado a seguir em nosso site de hospedagem criado para este estudo. ${ }^{43}$

É importante também lembrarmos que "unigramas", "bigramas", "trigramas" e “quadrigramas" referem-se a uma nomenclatura utilizada pela Linguística de Corpus para definir o conjunto de combinações recorrentes de possíveis candidatos a vocábulos: "unigrama" pode ser interpretado como lexia simples, ao passo que "bigrama", "trigrama" e "quadrigrama" (unidades com dois, três e quatro vocábulos, respectivamente) podem ser interpretadas como possíveis concordâncias de lexias complexas. ${ }^{44}$

\section{a) lexias simples: unigramas}

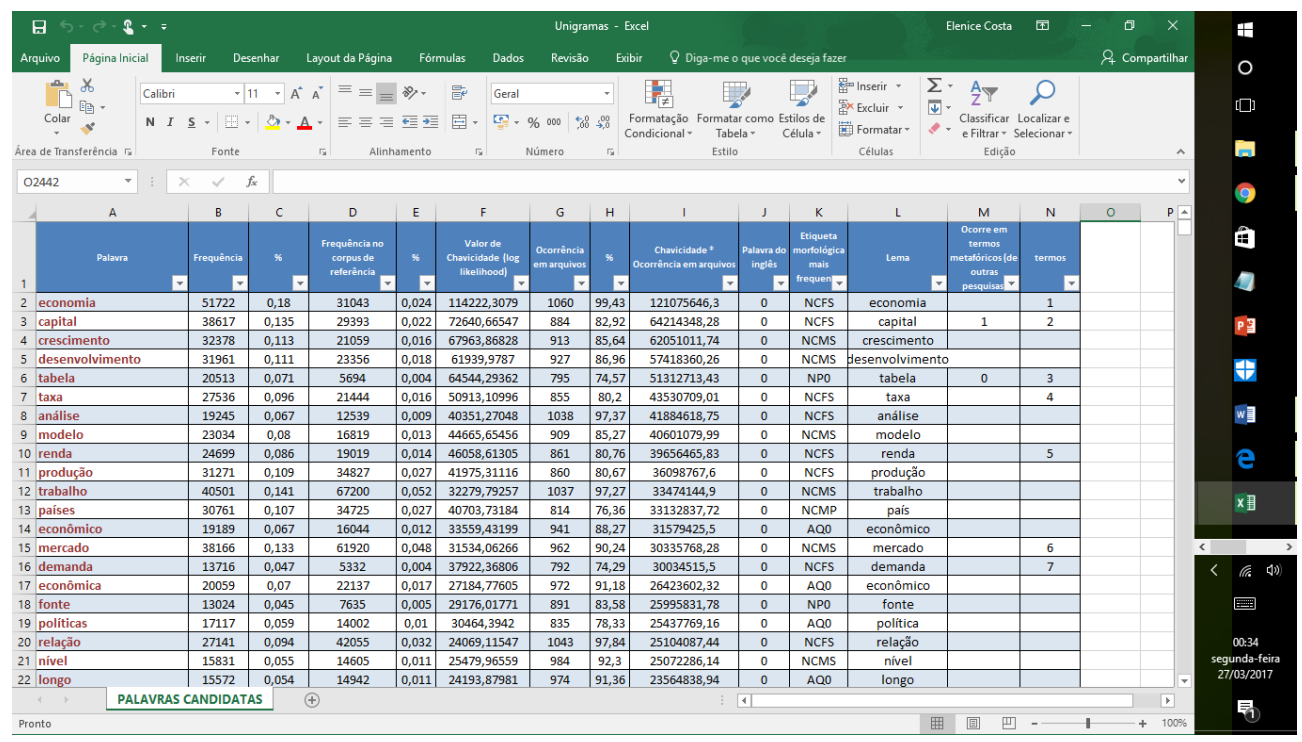

Figura 13 - Demonstração da planilha de unigramas.

\footnotetext{
${ }^{43}$ Disponível em: <http://corpusdeeconomia.net/x/\#>.

${ }^{44}$ Retomando a tipologia proposta por Pottier e Sablayrolles (2000, p. 148), esta noção de lexia simples e complexa refere-se, no primeiro caso, a formações com somente uma palavra; na segunda situação, a sequências em via de lexicalização em diferentes gradações.
} 


\section{b) lexias complexas: bigramas}

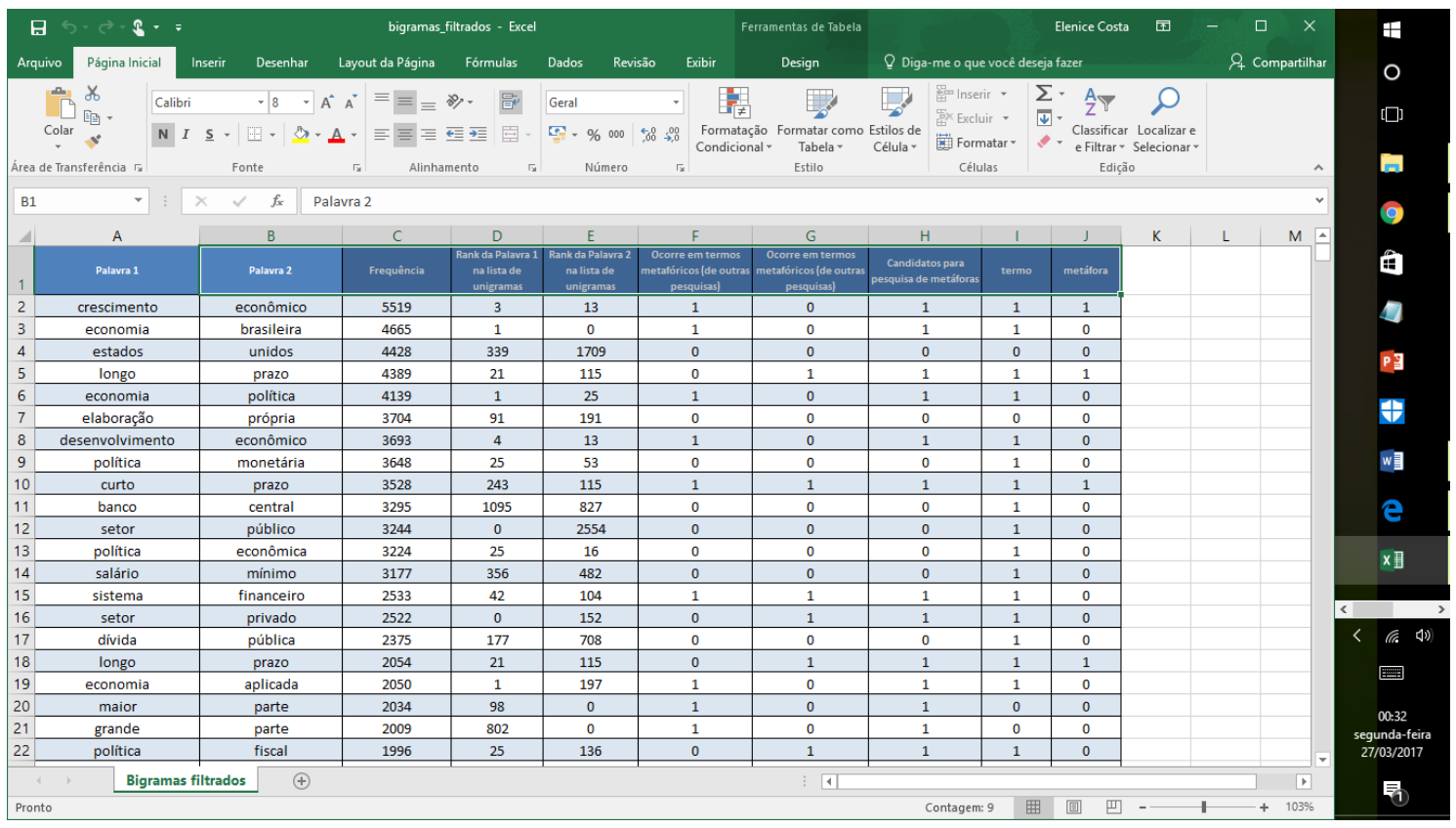

Figura 14 - Demonstração da planilha de bigramas.

\section{c) lexias complexas: trigramas}

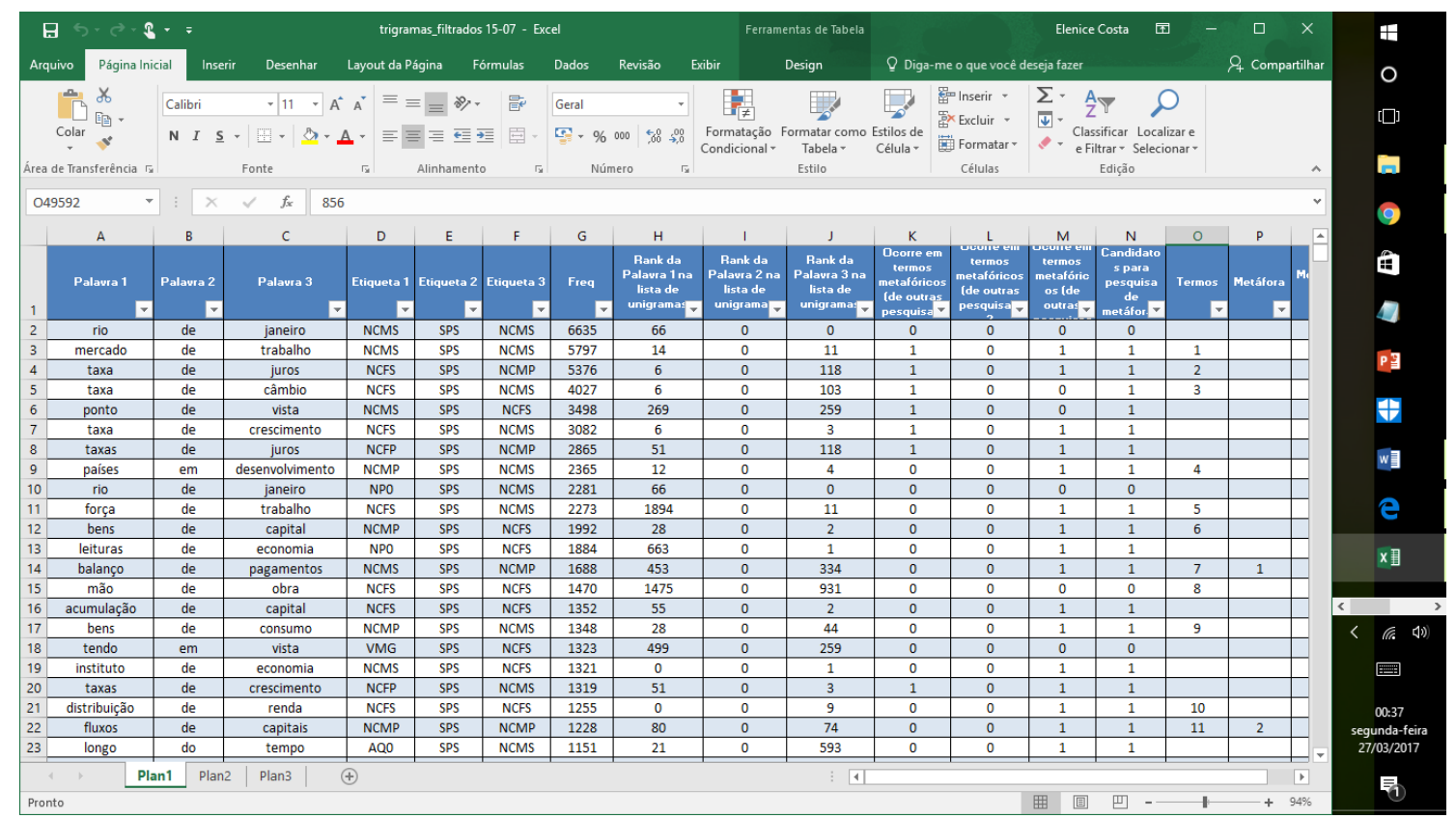

Figura 15 - Demonstração da planilha de trigramas. 


\section{d) lexias complexas: quadrigramas}

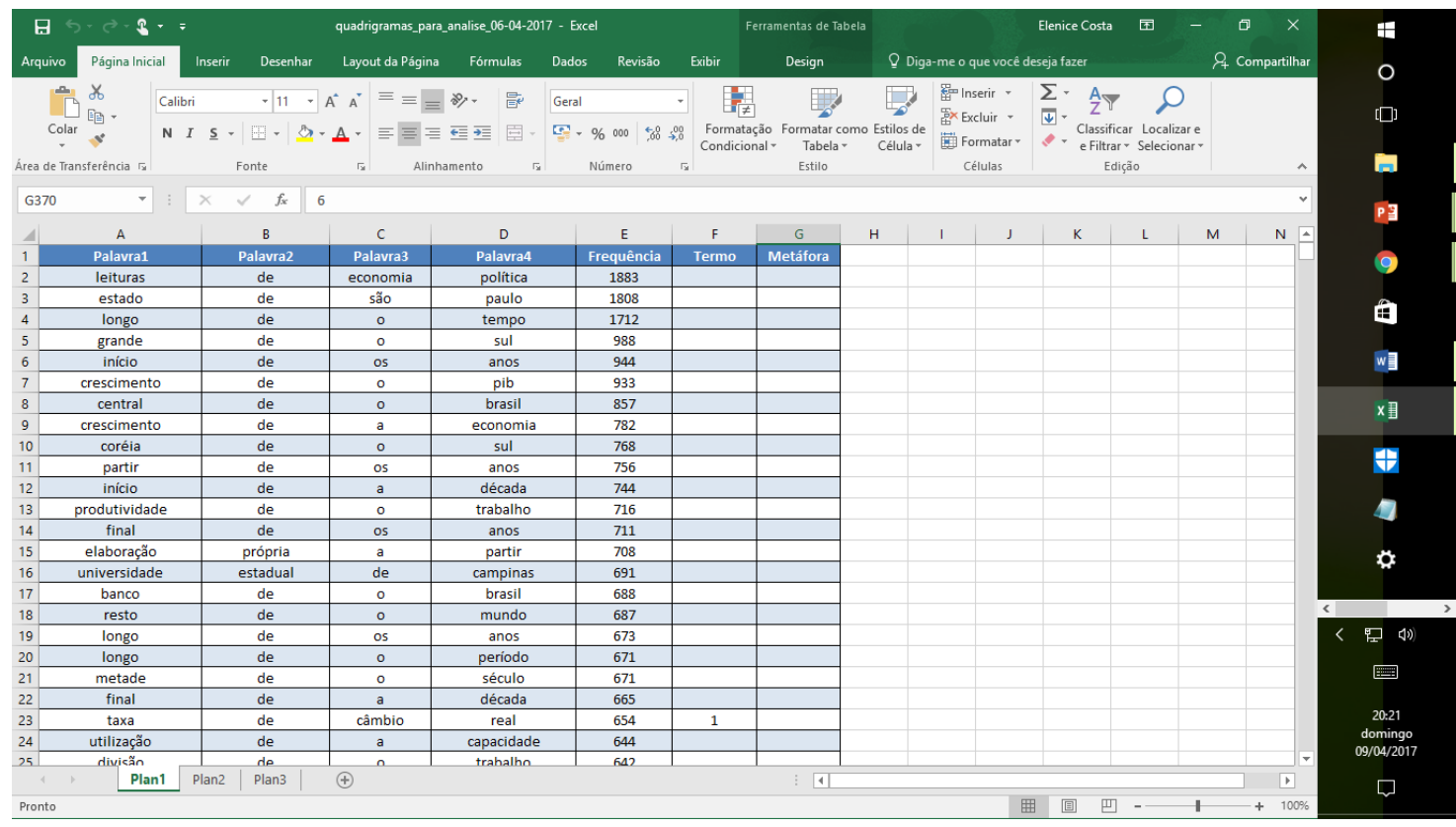

Figura 16 - Demonstração da planilha de quadrigramas.

No exemplo da planilha dos quadrigramas, podemos observar a presença do possível candidato a termo "partir de os anos". Porém, ele foi descartado, uma vez que não se inicia por uma palavra substantiva, por exemplo.

Notamos também nesse mesmo caso a contração das preposições "da(s)" ou “do(s)" que aparecem como "de a ou $a s "$ e "de o ou os". Isso ocorre porque, para organizar os n-gramas, foi utilizada a itemização realizada pelo TreeTagger. Para considerar "dos" como apenas 1 item, teríamos de fazer uma função para juntá-los novamente, alterando a itemização. Contudo, esse procedimento não foi feito para que assim pudéssemos gerar os $n$-gramas. Apenas na interface do corpus de Economia online foi realizada a alteração no retorno dos resultados.

\subsection{Criação de site para armazenamento de dados para busca}

Após o processamento dos corpora por meio de programação em Python, com a criação de listas de frequência e aplicação de filtros, decidiu-se pela criação de um ambiente para pesquisa dos dados processados do corpus de estudo a fim de facilitar as demais etapas da pesquisa, principalmente em relação à análise de contextos. 
Para tanto, foi contratada uma hospedagem de site compartilhada (conforme já mencionado anteriormente), com recursos básicos (Sistema Operacional Linux, banco de dados MySQL e suporte a páginas em linguagem PHP) para armazenar os dados processados e hospedar as interfaces de buscas necessárias para a pesquisa. As interfaces foram criadas pelo mesmo programador - Dr. José Lopes Moreira Filho - utilizando o processamento dos dados do corpus de estudo.

O site criado foi disponibilizado no domínio <http://corpusdeeconomia.net>, o qual contou com os seguintes recursos e interfaces de busca:

- página com informações gerais do corpus (número de itens, número de formas, razão forma/item e número de arquivos) e acesso às ferramentas da interface;

- página de acesso aos textos do corpus em três diferentes formatos:

- a. textos originais em PDF;

- b. textos convertidos em TXT, texto sem formatação;

- c. textos etiquetados com o Etiquetador TreeTagger.

- página de acesso à lista de frequência do corpus;

- página de acesso e busca às listas de frequência de n-gramas (unigramas, bigramas, trigramas e quadrigramas);

- página de busca para geração de linhas de concordância a partir de palavra ou termo de busca, com recurso de visualização de contexto ampliado e acesso ao arquivo original em PDF.

A figura a seguir mostra o exemplo de interface para pesquisa de linhas de concordância a partir de um termo de busca:

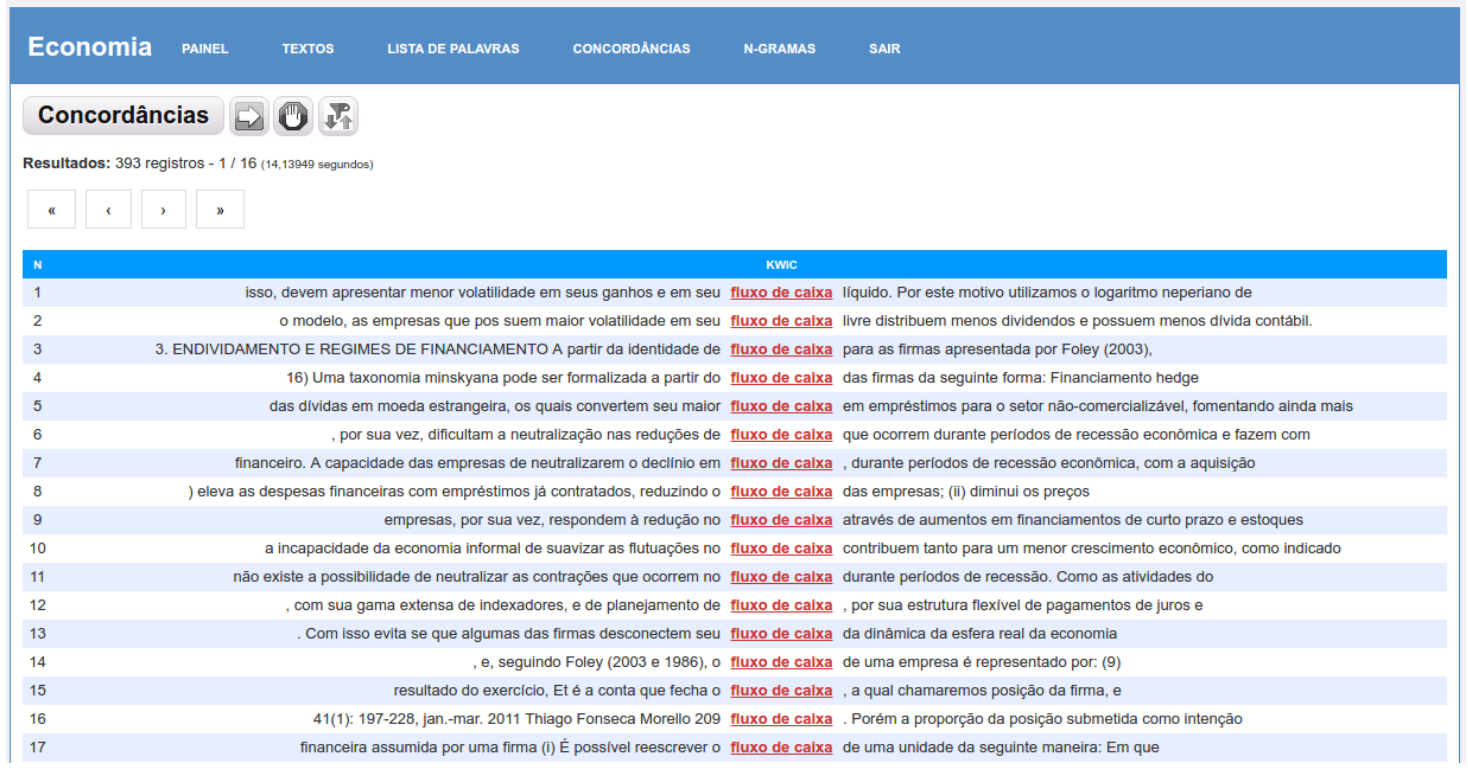

Figura 17 - Exemplo de interface para gerar linhas de concordância. 
No exemplo acima, foram exibidas as linhas de concordância de ocorrências do termo 'fluxo de caixa', que fica centralizado em cor diferenciada (vermelho). Em cada linha de concordância é possível ampliar o tamanho do contexto exibido clicando-se no hyperlink do termo. Ao se fazer isso, o programa gera uma janela com o contexto ampliado, como mostra o seguinte exemplo:

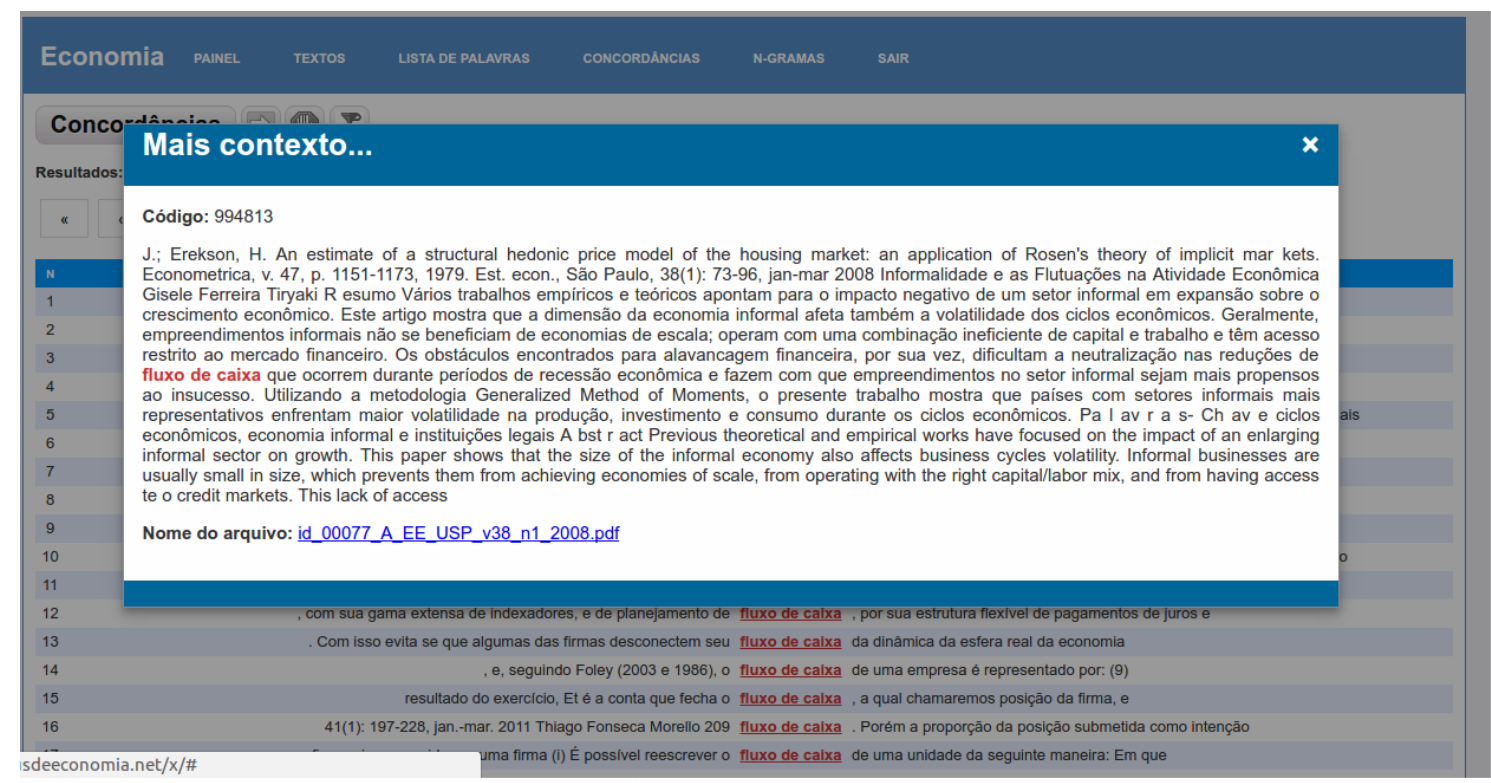

Figura 18 - Exemplo de linha de concordância com contexto ampliado.

Nessa janela, verifica-se a disponibilização do código da palavra/termo no banco de dados, o contexto ampliado e o nome do arquivo original em PDF, com um hyperlink para acessar o arquivo caso tenhamos necessidade de pesquisá-lo, recuperando assim o termo no arquivo original; clicando-se no hyperlink e utilizando-se os próprios recursos de busca de qualquer navegador de internet, como mostra a figura abaixo ${ }^{45}$ :

\footnotetext{
45 Todas as pessoas que tenham acesso ao corpus terão acesso ao texto na íntegra.
} 


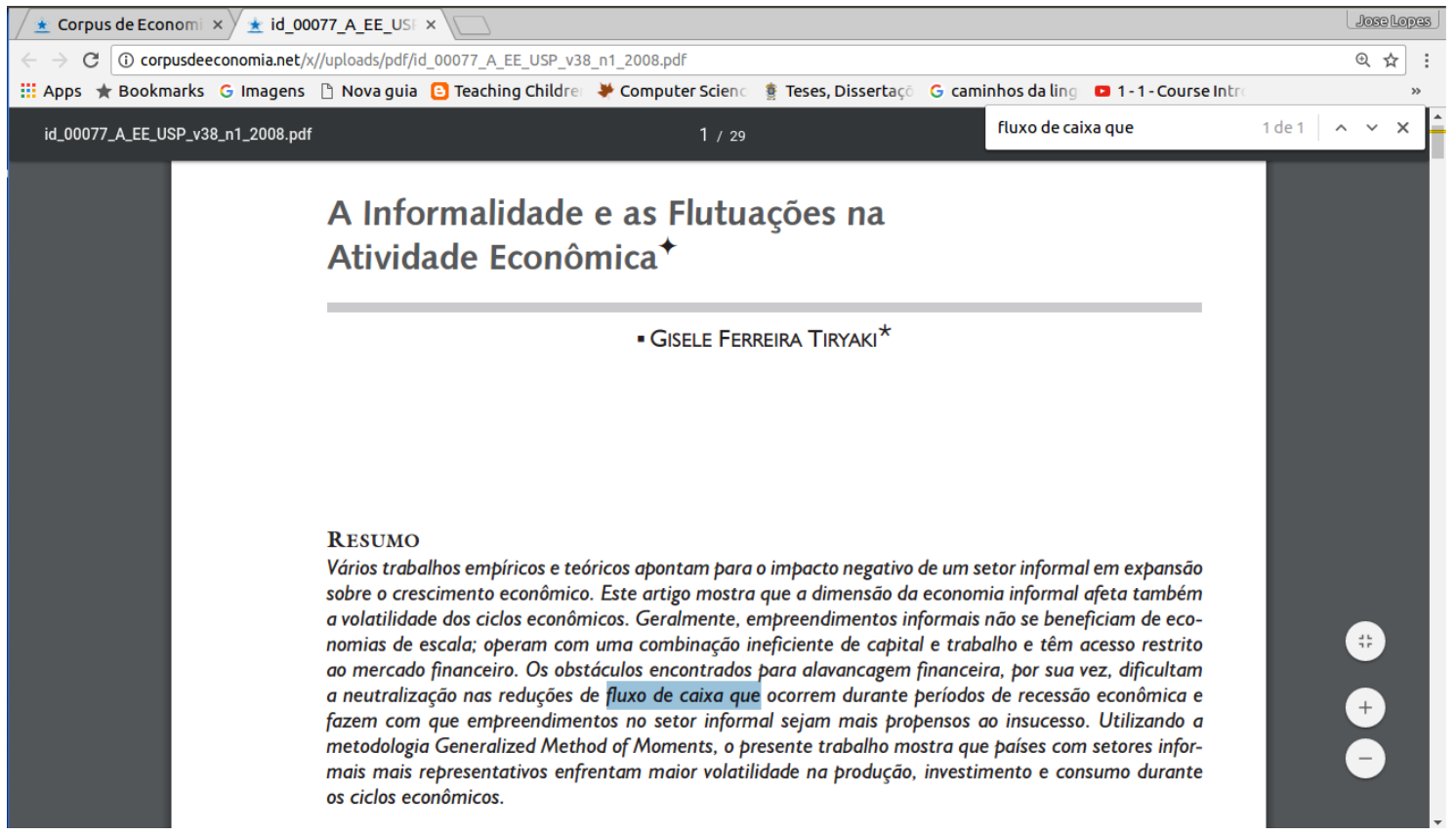

Figura 19 - Busca de termo em arquivo original do corpus.

Esses exemplos demonstram a facilidade de manipulação dos dados do corpus a partir de interfaces criadas especificamente para tal fim, permitindo-nos concentrar nas análises linguísticas ao invés de nos preocuparmos com questões técnicas em informática.

Assim, foram constituídas as principais ferramentas necessárias para a análise dos termos metafóricos identificados no corpus de estudo.

\subsection{Procedimentos de análise dos candidatos a termos metafóricos da Economia}

O exame e a seleção dos candidatos a termos, após a geração das planilhas, foi realizado manualmente, pois sabemos que apenas critérios quantitativos apresentados por essas ferramentas eletrônicas não são suficientes para a detecção de termos. Queremos frisar aqui também que a linguagem de programação com os objetivos de desenvolver ferramentas aplicadas à Linguística de Corpus pode fazer o trabalho da geração de listas de candidatos a termo, algo que auxilia bastante o trabalho do analista. No entanto, de acordo com Salgado (2011, p. 9), a seleção daquilo que será objeto de análise linguística continuará sendo feita pelo pesquisador/terminólogo em conjunto com o especialista da área.

Assim, para extrairmos os termos da planilha, seguimos alguns critérios destacados a seguir: 
- o primeiro critério foi o semântico (considerado por nós o mais importante), o qual, de acordo com Teline, Almeida e Aluísio (2003, s.p.), implica selecionar, em um determinado campo nocional, os termos/conceitos relevantes de uma determinada área de especialidade;

- o segundo foi o aspecto formal (morfológico), uma vez que a maior parte dos termos na Economia - conforme já foi demonstrado em alguns estudos realizados, por exemplo, por Gomez de Enterría (2000) e Alves (2001b) - são formados por composições sintagmáticas, o que facilitou o reconhecimento de termos da Economia nas planilhas dos bigramas, trigramas e quadrigramas;

- o terceiro critério adotado foi o do contexto, uma vez que, por meio dele, podemos compreender e elaborar a definição do termo, conforme pode ser demonstrado em relação ao termo choque fiscal, em que a Unidade Terminológica (UT) é definida pelo contexto apresentado entre parênteses (aumento do gasto real do governo):

[...] Portanto, quando ocorre um <choque fiscal (aumento do gasto real do governo)> não anunciado, ambas as taxas de câmbio se deslocam na mesma intensidade para os seus novos equilíbrios de estado estacionário. Est. econ., São Paulo, 40(3): 535-559, jul.-set. 2010. (Nome do arquivo: id_00137_A_EE_USP_v40_n3_2010.pdf).

- o quarto foi relativo à consulta a dicionários especializados da Economia: o Dicionário de economia do século XXI, de Sandroni (2005), o Glossário de termos neológicos da economia, de Ieda Maria Alves $(2001)^{46}$ e o Dicionário de termos financeiros e bancários, de Maria Tereza Biderman (2013).

- o quinto critério adotado para a triagem de algumas das unidades terminológicas, as mais difíceis para a nossa compreensão, foi a consulta realizada a alguns especialistas, como os professores e economistas Adriano Henrique Rebelo Biava, da Universidade de São Paulo (FEA-USP), Alberto Ajzental (Fundação Getúlio Vargas) e Ladislau Dowbor (Pontifícia Universidade Católica de São Paulo).

\footnotetext{
${ }^{46}$ No caso dessa referência, os termos apresentados foram extraídos de um corpus de divulgação, dentre os quais muitos deles já são estáveis na terminologia da Economia.
} 
Após a triagem dos termos por meio das planilhas, fomos enumerando cada um deles para que, no final delas, tivéssemos o número total de termos analisados. Em seguida, criamos uma nova coluna para selecionar, dentre esses termos, os que apresentavam metáfora. Os termos metafóricos também foram enumerados na planilha a fim de que pudéssemos apresentar dados quantitativos sobre o número de metáforas encontradas nesse tipo de terminologia. A seguir, um exemplo de uma das planilhas:

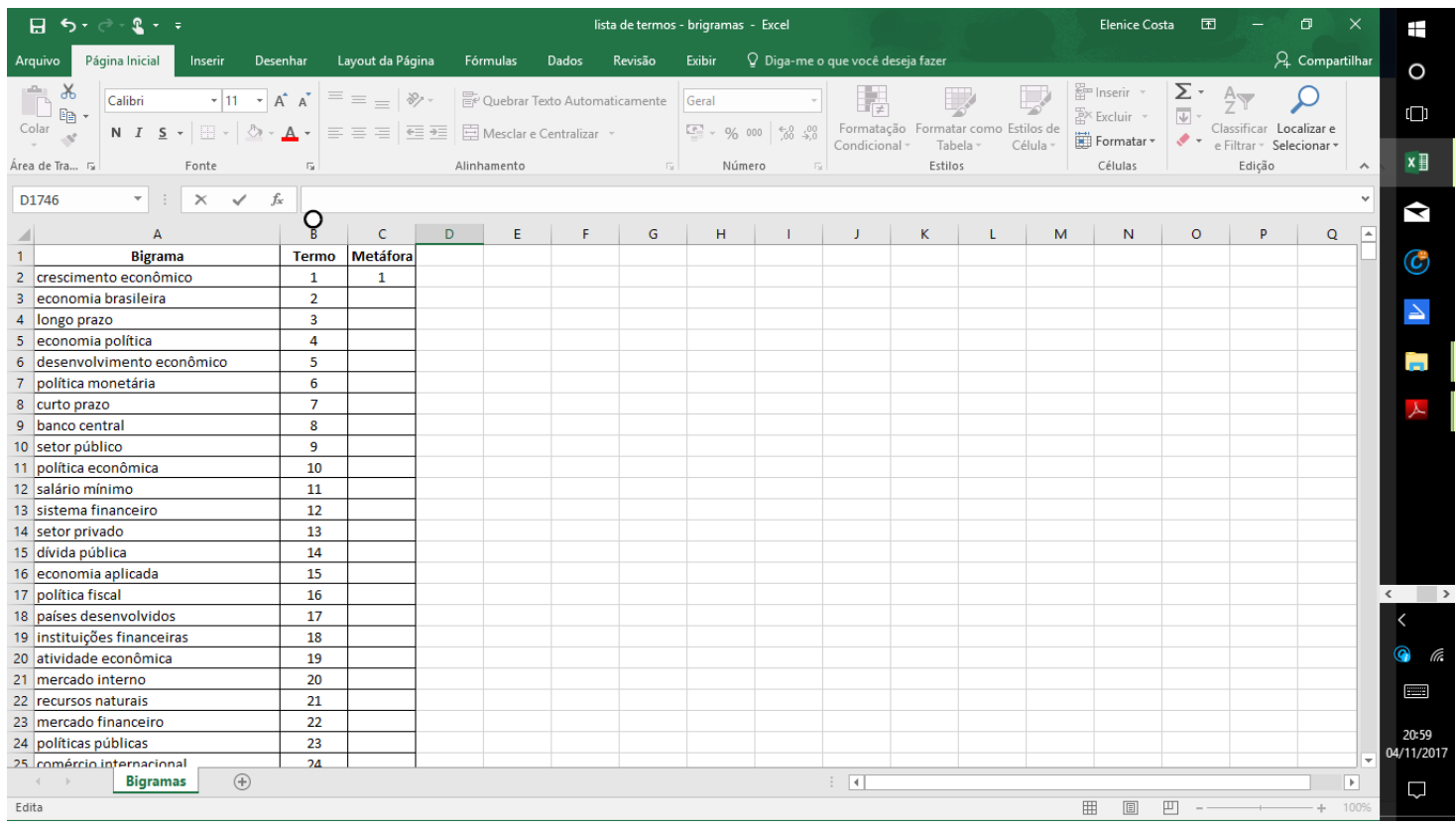

Figura 20 - Planilha de termos da Economia.

Por último, os dados quantitativos da tabulação dos termos triados das planilhas podem ser resumidos da seguinte forma:

A) Quantidade de candidatos a termos (totais analisados), quantidade de termos triados (termos), quantidade de types (formas), quantidade de metáforas e sua porcentagem em relação aos termos selecionados:

\begin{tabular}{|l|l|}
\hline Quantidade de termos & Quantidade de termos metafóricos \\
\hline $\begin{array}{l}\text { Lexias simples (unigramas) } \\
\text { - totais analisados 2.600 }\end{array}$ & 25 \\
Termos = 116 & $3 \%$ \\
$\mathbf{4 9 1 . 7 7 8}$ types & \\
\hline $\begin{array}{l}\text { Lexias complexas (bigramas) } \\
\text { - totais analisados 37.600 }\end{array}$ & 348 \\
Termos 3.171 & $40 \%$ \\
\hline
\end{tabular}




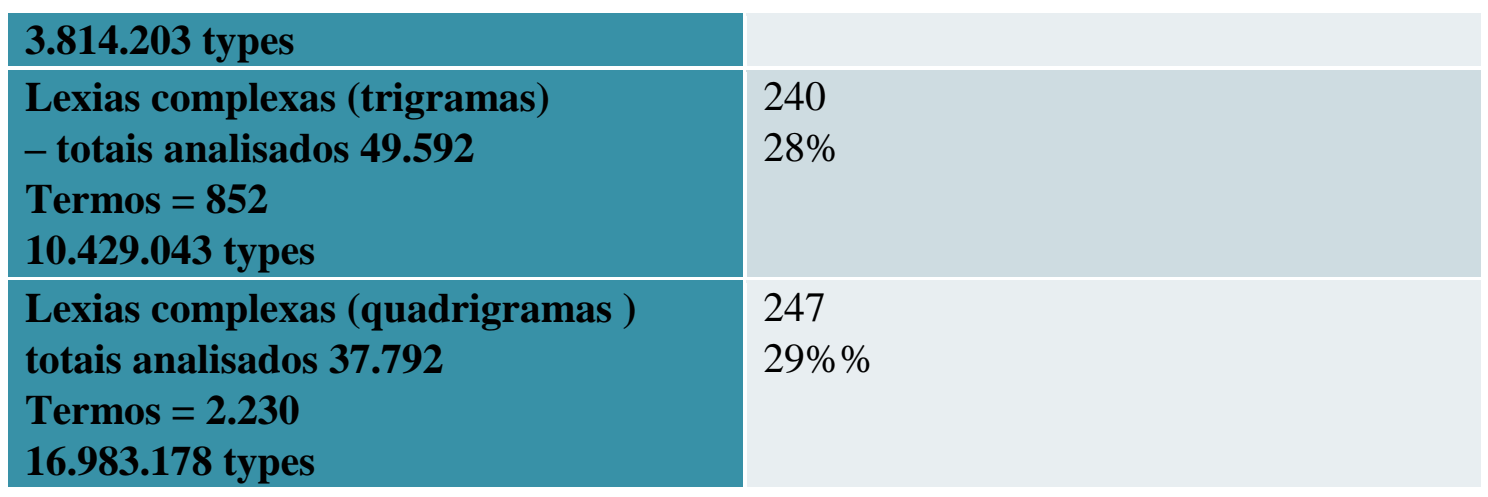

Análise dos dados apresentados na tabela acima

Os dados apresentados pela tabela permitem-nos considerar que, em relação à quantidade de unigramas, ou seja, de lexias simples do tipo liquidez, observamos que, no que se refere ao número total de unidades da planilha de candidatos a termo analisadas (2.600) e o número de unidades terminológicas triadas, esse valor é baixo (igual a 116, das quais 25 delas são metafóricas).

Consideramos que isso ocorra pelo fato de haver na língua de especialidade um número maior de formações sintagmáticas do que lexias simples, uma vez que em toda terminologia a linguagem necessita de especificações para a denominação dos conceitos. Na tese de doutorado defendida por Oliveira (2011, p. 53), a frequência do número de lexias simples analisadas por ela na terminologia da genética também é bastante reduzida. ${ }^{47}$

Essa baixa frequência de lexias simples também aparece em dicionários especializados da Economia, como o Glossário de termos neológicos da Economia (ALVES, 2001a). De um universo de 601 termos (subtraindo-se os estrangeirismos, o que totaliza 535 unidades), apenas 25 deles são lexias simples, ou seja, apenas 3\%. Dos termos captados do nosso corpus para esta pesquisa, de um total de 6.339, apenas 116 são termos de apenas uma unidade - como, por exemplo, volatilidade -, o que corresponde à porcentagem de $3 \% .^{48}$

\footnotetext{
${ }^{47}$ Ela cita apenas três casos de metáforas prospectadas em lexias simples em processos genéticos, tais como "ancoragem", "tradução" e "transcrição" e mais três em unidades genéticas: "mapa", "marcador" e "biblioteca".

${ }^{48}$ Para Rosa (2008, p.8), as metáforas nas lexias simples estão revestidas de toda a propriedade referencial. Porém, na dissertação defendida por ela, não há comparações ou apresentação de dados numéricos que comprovem que há mais metáforas nas lexias simples do que nas formações sintagmáticas do tipo trigrama, por exemplo.
} 
Nas formações sintagmáticas, a quantidade de termos é mais expressiva nos bigramas - totalizando 3.171 termos compostos por duas palavras, a exemplo de crise financeira - do que nos trigramas (os quais totalizaram 852 unidades de termos compostos por três palavras, a exemplo de fundos de pensão) e ou nos quadrigramas (2.230 termos compostos por mais de quatro vocábulos, como, por exemplo, fundos de renda fixa).

Apesar de haver um número maior de candidatos a termos nos trigramas (49.592) do que nos bigramas (37.600), o número de unidades terminológicas triadas nestes é quase quatro vezes maior do que nos trigramas. Isso ocorre porque, conforme dados de estudos já realizados anteriormente (ALVES, 1999), ou mesmo em nossa dissertação de mestrado (COSTA, 2007), as formações sintagmáticas são predominantemente do tipo $\mathrm{S}+\mathrm{A}$ (substantivo mais adjetivo), ${ }^{49}$ uma vez que o segundo elemento tende a ser o especificador do termo mais genérico; formações do tipo $\mathrm{S}+\mathrm{SP}^{50}$ (substantivo + sintagma preposicionado) são majoritárias nos trigramas, também encontradas com bastante frequência nos quadrigramas (substantivo + sintagma preposicionado + adjetivo) $)^{51}$. Interessante notar que os quadrigramas apresentam um número superior de ocorrências de termos (2.230), quase três vezes a mais do que nos trigramas (852). Conjecturamos que isso aconteça pelo fato de que, nos quadrigramas, o elemento especificador aparece depois do sintagma preposicionado, que é o caso, por exemplo, do termo fluxo de capital estrangeiro.

Em relação à quantidade de termos metafóricos encontrados (860), observamos que eles aparecem com maior frequência (40\%) nos bigramas, quadrigramas (29\%) e trigramas $(28 \%)$ - ou seja, predominantemente nas lexias complexas. Completando os resultados encontrados, as lexias simples correspondem a um valor baixíssimo de somente $3 \%$ dos termos, resultado esse em muito devido às razões já expostas neste trabalho.

\footnotetext{
${ }^{49}$ São inúmeras as ocorrências desse tipo de formação dentre os termos coletados para nosso estudo, tais como choque inflacionário, âncora fiscal, crise financeira, economia aberta, flutuação cambial, entre outras.

${ }^{50}$ Em relação a esse tipo de formação, seguem também alguns exemplos ocorrentes neste corpus: alavancagem de crédito, balança de pagamento, bolha de ações, choque de juros, entre outros.

${ }^{51}$ Para ilustrar uma dessas formações dos quadrigramas em estudo, citamos, por exemplo: fluxo de capital estrangeiro, fundo de acumulação interna, regime de câmbio flutuante, entre outros exemplos.
} 
B) Total de registros (types/formas), total de candidatos a termos analisados, total de termos e quantidade de metáforas em porcentagem:

\begin{tabular}{|l|l|l|l|l|}
\hline N-gramas & $\begin{array}{l}\text { Total de } \\
\text { registros } \\
\text { (types/formas) }\end{array}$ & $\begin{array}{l}\text { Total de } \\
\text { termos } \\
\text { analisados } \\
\text { (após filtros) }\end{array}$ & $\begin{array}{l}\text { Total de } \\
\text { termos triados } \\
\text { (após análise) }\end{array}$ & $\begin{array}{l}\text { Quantidade } \\
\text { de termos } \\
\text { metafóricos }\end{array}$ \\
\hline unigramas & 491.778 & 2.600 & $\mathbf{1 1 6}$ & $25(3 \%)$ \\
\hline bigramas & 3.814 .203 & 37.600 & $\mathbf{3 . 1 7 1}$ & $348(40 \%)$ \\
\hline trigramas & 10.429 .043 & 49.592 & $\mathbf{8 5 2}$ & $240(28 \%)$ \\
\hline quadrigramas & 16.983 .178 & 37.792 & $\mathbf{2 . 2 3 0}$ & $247(29 \%)$ \\
\hline
\end{tabular}

O número de porcentagem metafórica foi calculado levando-se em consideração o total de termos de cada um dos grupos, isto é, o total de 860 de termos metafóricos foi divido entre 25 termos metafóricos de unigramas, seguindo-se o mesmo raciocínio para os bigramas, trigramas e quadrigramas.

Em relação aos unigramas, a porcentagem é de $3 \%$ no que se refere ao número de 860 unidades metafóricas. Se fôssemos calcular a porcentagem de metáforas em relação ao número total de termos nos unigramas (116), essa porcentagem seria igual a $21 \%$. Isto é, em relação ao número total de metáforas a quantidade de unigramas é pequena, mas no tocante ao número de termos como "lexia simples", esse valor aumenta consideravelmente.

Nos bigramas, há 3.171 unidades terminológicas, das quais 348 são metafóricas. A porcentagem é igual a $40 \%$ em relação ao total de metáforas, porém se calcularmos esse valor levando em consideração o total de bigramas, esse número cai de forma expressiva para $11 \%$. Nesse caso, a situação se inverte se comparada com o caso dos unigramas. Ou seja, sua proporção é maior em relação ao número total de metáforas, mas não ocorre a mesma situação se levarmos em consideração a proporção ao número total de termos (3.171), o que significa que os termos metafóricos do tipo bigrama são bastante produtivos no que se refere ao número total de metáforas. Contudo, não ocorre o mesmo se comparado ao número total de termos. Nesse sentido, há menos metáforas no total de bigramas do que nas lexias simples. 
No que se refere aos trigramas, existem 852 termos, dos quais 240 são metafóricos; isso quer dizer que $28 \%$ deles são metafóricos em relação ao total de metáforas. Essa porcentagem se mantém a mesma se o cálculo for realizado levando-se em consideração o número total de trigramas, que é igual a 852 , ou seja, $28 \%$. De forma que há um número equilibrado de metáforas tanto em relação ao número total de metáforas, quanto no que se refere à quantidade de termos trigramas.

Por último, os quadrigramas apresentam $29 \%$ em relação ao número total de metáforas. Essa porcentagem é alterada de forma marcante se levarmos em consideração o número total de termos quadrigramas (2.230), ficando igual a $11 \%$ (situação parecida com a dos bigramas). 


\section{PARTE III}

\section{ANÁLISE DOS DADOS - TIPOLOGIA METAFÓRICA}

\subsection{Os domínios das metáforas da Economia}

O reconhecimento dos domínios cognitivos das metáforas nem sempre é uma tarefa fácil, uma vez que esse processo de categorização é subjetivo, pois baseia-se em nossas experiências prévias e culturais. Conforme Cameron (1999), um dos desafios metodológicos da análise da metáfora diz respeito à sua própria identificação e à explicitação das regularidades que delineiam o seu uso. Demonstraremos, portanto, uma de algumas possibilidades de agrupamento das metáforas do corpus de estudo explicitadas a seguir.

Para realizar tal intento, nos valemos de acepções de dicionários, tais como Dicionário Houaiss da língua portuguesa (2001) e Novo dicionário da língua portuguesa (1999), por serem considerados os principais da língua portuguesa no Brasil e também, sempre que possível, de um thesaurus (UNESCO Thesaurus). ${ }^{52}$ Julgamos também importante levar em consideração análises de domínios já estabelecidos por outros teóricos, tais como Charteris-Black e Ennis (2001), Berber Sardinha (2007), Deignan (2008), Silva (2013), Cardini (2014), Charteris-Black e Ennis (2001) e Alves (2016). Para o estabelecimento desses domínios, também observamos algumas ponderações feitas por especialistas, tais como Ajzental (2015), que estudou analogias entre metáforas da Economia e outras áreas do conhecimento especializado, tais como a Biologia e a Física.

Mediante a observação dos termos analisados extraídos de nosso corpus, podemos afirmar que um dos grandes campos cognitivos dos termos da Economia é relativo à área da Física. Somente nesse campo, registramos em nosso corpus de estudo em torno de 200 termos, os quais podem ser divididos em "subconceitos", tais como: ECONOMIA É MÁQUINA, ECONOMIA É COLISÃO, ECONOMIA É ESTADO GASOSO.

Domínios recorrentes à Biologia também são frequentes na Economia. É o caso, por exemplo, dos conceitos que aparecem com bastante frequência em nosso corpus de estudo, exemplificados com A ECONOMIA É UM CORPO ou ECONOMIA É UM ORGANISMO e ECONOMIA É DOENÇA, conceito explorado em Alves (2016) por meio das metáforas da crise econômica.

\footnotetext{
${ }^{52}$ Disponível em: <http://vocabularies.unesco.org/browser/thesaurus/>.
} 
Verificaremos mais adiante, portanto, que há dois grandes domínios selecionados, os da Física e da Biologia (conceitos esses responsáveis por subconceitos); mais à frente, serão apresentados alguns outros domínios, tais como os da "guerra", "fauna", "violência", entre outros, cujas frequências são bem menores se comparadas com os campos cognitivos da Física e da Biologia.

Nas tabelas a seguir, serão destacadas nas colunas de "domínio" alguns exemplos de termos metafóricos que foram lexicalizados a partir dos principais domínios-fonte (Tabela 1 - conceitos da Física; Tabela 2 - Biologia; Tabela 3 - Metáforas Orientacionais ${ }^{53}$ ). Após essa amostragem, haverá também uma coluna com o número de termos que aparecem para cada um desses conceitos - por exemplo, com "choque" ocorrem 64 termos no corpus e essas metáforas aparecem na forma de unigramas, bigramas, trigramas e quadrigramas, ou seja, em lexias simples e complexas; na última, a porcentagem da frequência de "conceitos" ou de "subconceitos" em um universo total de 860 unidades terminológicas metafóricas analisadas para essa classificação. Algumas metáforas podem aparecer em dois domínios diferentes pelo fato de uma mesma unidade apresentar duas metáforas, que é o caso de "liquidez de ativos defensivos" - "liquidez" aparecerá, portanto, na Tabela 1 (referente aos conceitos da Física) e “defensivos” será registrado na Tabela 4 , relativa a Outros Domínios (conceito da guerra por exemplo) ${ }^{54}$.

Por último, salientamos que, do total de 860 unidades metafóricas, nem todas foram analisadas, ora pelo fato de elas apresentarem uma baixa porcentagem ora pela condição de sua rasa "potencialidade cognitiva", uma vez que nem todas as metáforas são conceptuais. É o que afirmou, por exemplo, a professora Solange Vereza, da Universidade Federal Fluminense (UFF), em seu curso ministrado na USP (FFLCH) denominado Metáfora em uso: a perspectiva cognitiva-discursiva, no primeiro semestre de 2019, do qual participamos nesse mesmo ano.

\footnotetext{
${ }^{53}$ Os termos categorizados como metáforas orientacionais são também bastante produtivos em Economia. A tipologia dessas metáforas foi analisada por Lakoff e Jonhson (2002, [1980]). Para esses autores, elas partem da ideia de que a maior parte de nossos conceitos fundamentais é organizada em termos de uma ou mais metáforas de espacialização. Esses autores (2002, [1980], p. 59) asseguram que a maioria delas se referem a orientações espaciais do tipo para cima/para baixo, dentro/fora, frente/trás, em cima de/fora de, fundo/raso, central/periférico. Também consideram que tais orientações de caráter metafórico não são arbitrárias, pois surgem da nossa experiência física e cultural. Embora as oposições binárias para cima/para baixo, dentro/fora etc. sejam físicas em sua natureza, as metáforas orientacionais são calcadas em experiências que podem variar de uma cultura para outra.

${ }^{54}$ Serão apresentados apenas poucos exemplares de cada uma das unidades simples (unigramas) e complexas (bigramas, trigramas e raramente quadrigramas), caso ocorram todos esses tipos de formações. Os termos extraídos de seus contextos serão ilustrados no momento da análise.
} 
TABELA 1

\begin{tabular}{|c|c|c|c|}
\hline \multicolumn{4}{|c|}{ Discurso científico } \\
\hline Domínio: Física & Exemplos & $\begin{array}{l}\text { Quantidade } \\
\text { termos } \\
\text { metafóricos para } \\
\text { cada um dos } \\
\text { conceitos } \\
\text { estabelecidos }\end{array}$ & Porcentagem (\%) \\
\hline \multicolumn{4}{|c|}{ Subconceitos da Física } \\
\hline instantaneidade & $\begin{array}{l}\text {. liquidez } \\
\text { liquidez } \\
\text { financeira } \\
\text {. ciclos de liquidez } \\
\text {. liquidez de curto } \\
\text { prazo }\end{array}$ & 117 & 14 \\
\hline impacto & $\begin{array}{l}\text { choque } \\
\text { choque exógeno } \\
\text {. choque de oferta } \\
\text {. choque de política } \\
\text { monetária }\end{array}$ & 64 & 7.4 \\
\hline dissipação & $\begin{array}{l}\text {. volatilidade } \\
\text {. volatilidade } \\
\text { cambial } \\
\text {. volatilidade de } \\
\text { preços } \\
\text {. volatilidade do } \\
\text { câmbio nominal }\end{array}$ & 32 & 3.7 \\
\hline & . bolha & 18 & 2.1 \\
\hline
\end{tabular}




\begin{tabular}{|c|c|c|c|}
\hline & $\begin{array}{l}\text { bolha especulativa } \\
\text { bolha de preços } \\
\text {. bolha de ativos } \\
\text { financeiros e } \\
\text { imobiliários }\end{array}$ & & \\
\hline equilíbrio & $\begin{array}{l}. \text { balanço } \\
\text {. balanços } \\
\text { financeiros } \\
\text {. balanço de } \\
\text { pagamentos } \\
. \text { balanço de } \\
\text { transações } \\
\text { correntes } \\
. \text { balança }\end{array}$ & $\begin{array}{l}29 \\
5\end{array}$ & 3.3 \\
\hline flexibilidade & $\begin{array}{l}\text {. elasticidade } \\
\text {. elasticidade-preço } \\
\text {. elasticidade-renda } \\
\text { da demanda } \\
\text {. ineslaticidade de } \\
\text { produção }\end{array}$ & 25 & 2.8 \\
\hline impulso & $\begin{array}{l}\text {. alavancagem } \\
\text {. alavancagem } \\
\text { bancária } \\
\text {. taxa de } \\
\text { alavancagem } \\
\text {. taxa absoluta de } \\
\text { alavancagem }\end{array}$ & 16 & 1.8 \\
\hline $\begin{array}{ll}\text { aumento } & \text { ou } \\
\text { diminuição } & \text { de } \\
\text { velocidade } & \end{array}$ & $\begin{array}{l}\text {. aceleração } \\
\text {. aceleração da } \\
\text { inflação }\end{array}$ & 12 & 1.3 \\
\hline
\end{tabular}




\begin{tabular}{|c|c|c|c|}
\hline & $\begin{array}{l}\text { Programa de } \\
\text { Aceleração do } \\
\text { Crescimento (PAC) }\end{array}$ & & \\
\hline temperatura & $\begin{array}{l}\text {. aquecimento ou } \\
\text { desaquecimento da } \\
\text { economia } \\
\text {. aquecimento do } \\
\text { mercado } \\
\text { imobiliário } \\
\text {. congelamento de } \\
\text { preços }\end{array}$ & 4 & 0.4 \\
\hline desintegração & $\begin{array}{l}\text {. entropia } \\
\text {. Lei da Entropia }\end{array}$ & 2 & 0.2 \\
\hline luminosidade & $\begin{array}{l}\text {. efeito-farol } \\
\text { preço-sombra }\end{array}$ & $\begin{array}{l}1 \\
1\end{array}$ & $\begin{array}{l}0.1 \\
0.1\end{array}$ \\
\hline medida & . calibragem & 1 & 0.1 \\
\hline \multirow[t]{2}{*}{ atrito } & fricção financeira & 1 & 0.1 \\
\hline & & $\begin{array}{l}\text { Total de termos } \\
\text { metafóricos da } \\
\text { Tabela } 1=328\end{array}$ & \\
\hline
\end{tabular}

TABELA 2

Discurso científico

\begin{tabular}{|l|l|l|l|}
\hline Domínio: Biologia & Exemplos & $\begin{array}{l}\text { Quantidade de } \\
\text { termos }\end{array}$ & Porcentagem (\%) \\
\hline
\end{tabular}




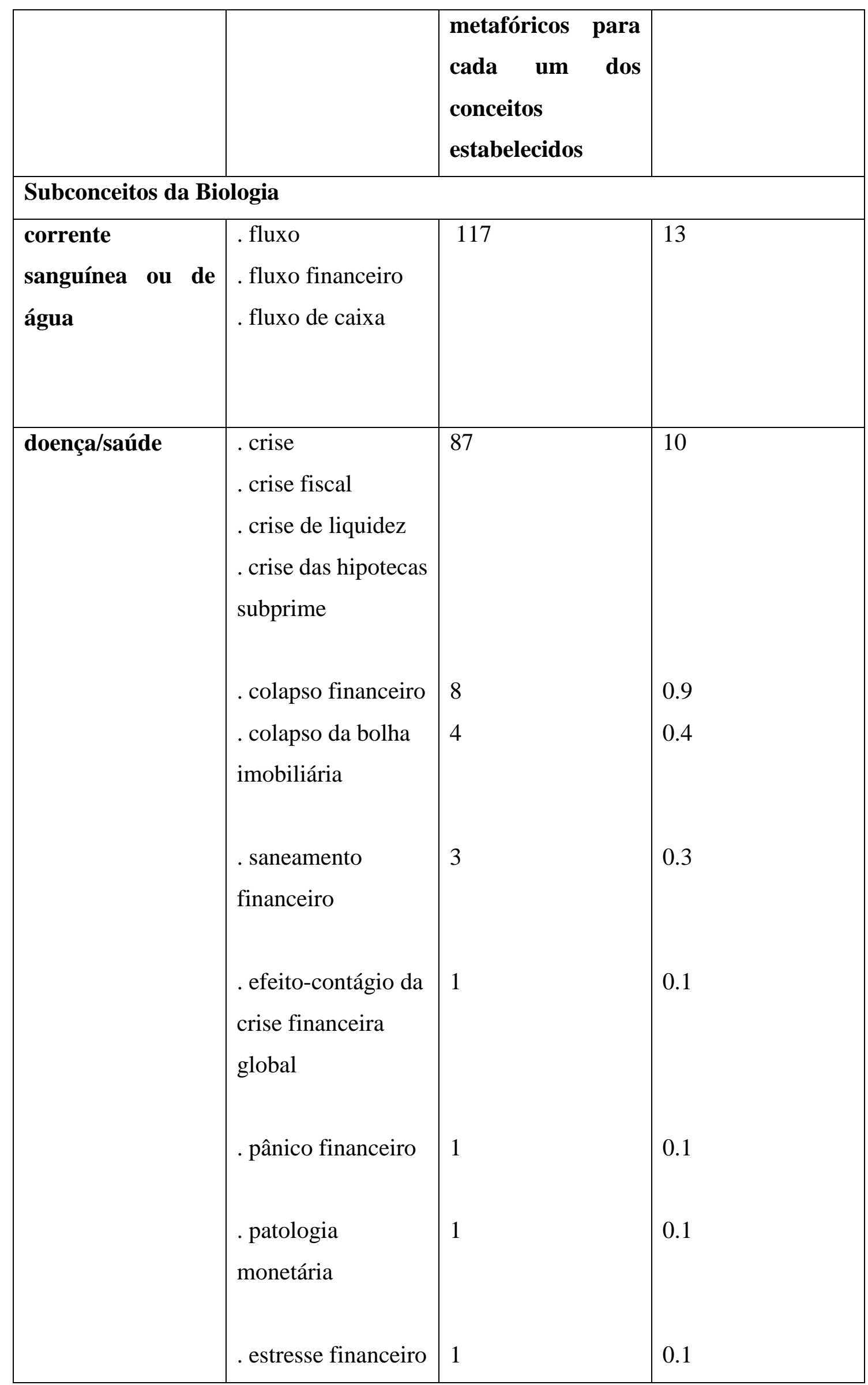




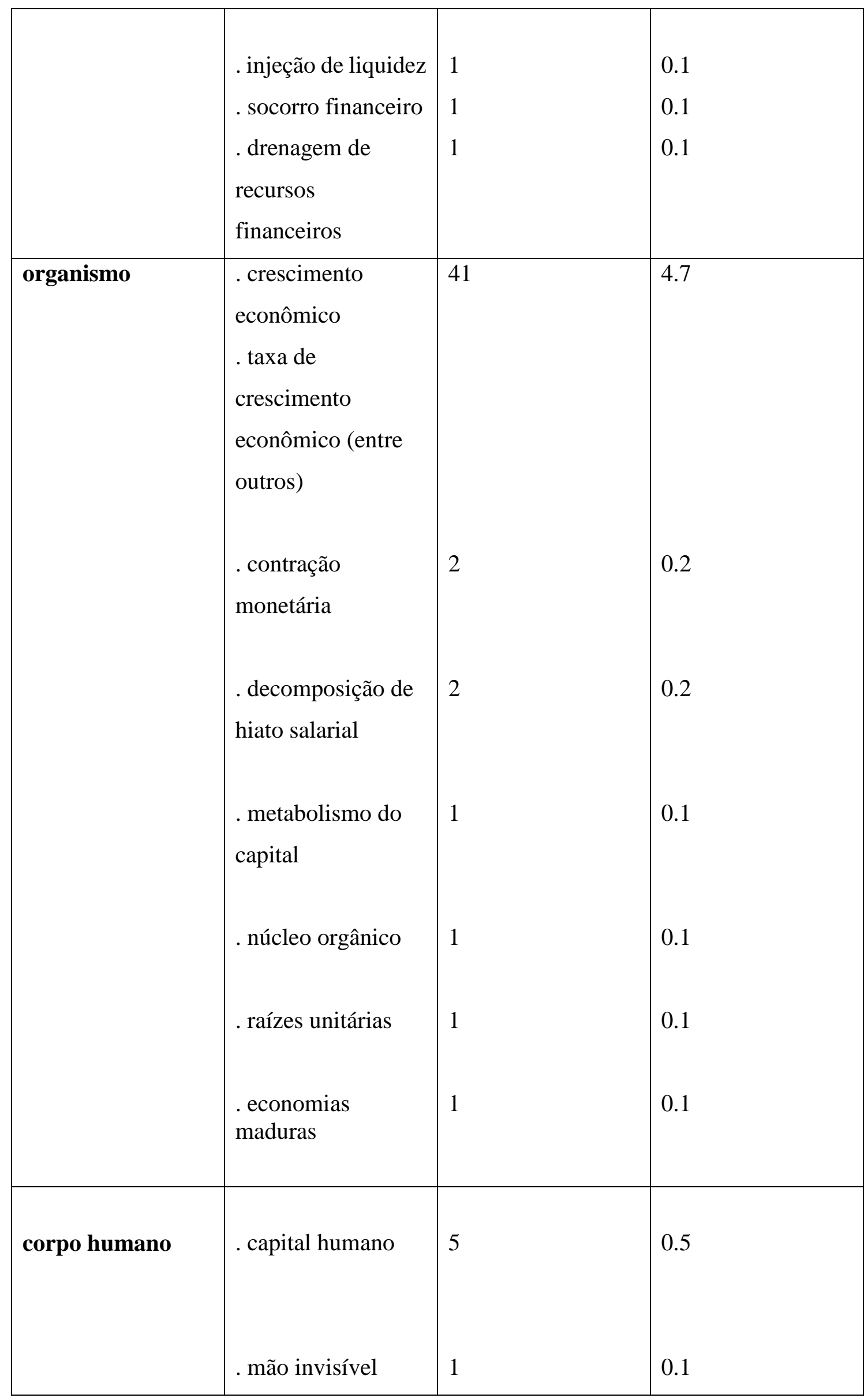




\begin{tabular}{|l|l|l|l|}
\hline & $\begin{array}{l}\text {. mão da liquidez } \\
\text {. braço financeiro } \\
\text {. déficits gêmeos }\end{array}$ & 1 & 0.1 \\
& 1 & 0.1 \\
\hline & . valor ecológico & 1 & 0.1 \\
\hline ecologia $^{55}$ & & $\begin{array}{l}\text { Total de termos } \\
\text { metafóricos da } \\
\text { Tabela 2 }=\mathbf{2 8 5}\end{array}$ & \\
\hline & &
\end{tabular}

TABELA 3

\begin{tabular}{|c|c|c|c|}
\hline $\begin{array}{l}\text { Conceitos de } \\
\text { espacialização }\end{array}$ & Exemplos & $\begin{array}{l}\text { Quantidade de } \\
\text { termos }\end{array}$ & Porcentagem \\
\hline fundo & $\begin{array}{l}\text {. fundo } \\
\text {. fundo mútuo } \\
\text {. fundo de ações } \\
\text {.fundo de } \\
\text { estabilização fiscal } \\
\text { (entre outros) }\end{array}$ & 103 & 12 \\
\hline $\begin{array}{l}\text { alto } \\
\text { baixo }\end{array}$ & $\begin{array}{l}\text {. alta } \\
\text {. alta liquidez } \\
\text {. ativos de alta } \\
\text { liquidez (entre } \\
\text { outros) }\end{array}$ & 7 & 0.7 \\
\hline & $\begin{array}{l}\text { baixa } \\
\text {. baixa liquidez } \\
\text { (entre outros) }\end{array}$ & 4 & 0.4 \\
\hline
\end{tabular}

${ }^{55}$ Ecologia é categorizado nesta análise como um conceito da Biologia, visto que de acordo com Houaiss (2001, p. 1097), essa noção aparece definida como um ramo das ciências biológicas que estuda as relações dos seres vivos entre si ou com o meio orgânico ou inorgânico no qual vivem. 


\begin{tabular}{|c|c|c|c|}
\hline Vertical/horizontal & $\begin{array}{l}\text {. desverticalização } \\
\text { da produção } \\
\text {. horizontalização }\end{array}$ & $\begin{array}{l}1 \\
1 \\
1\end{array}$ & $\begin{array}{l}0.1 \\
0.1\end{array}$ \\
\hline central & $\begin{array}{l}\text {. espiral } \\
\text { inflacionária }\end{array}$ & 1 & 0.1 \\
\hline \multirow[t]{2}{*}{ lateral } & . andar de lado & 1 & 0.1 \\
\hline & & $\begin{array}{l}\text { Total de termos } \\
\text { metafóricos da } \\
\text { Tabela } 3=118\end{array}$ & \\
\hline
\end{tabular}

TABELA 4

\begin{tabular}{|c|c|c|c|}
\hline Outros domínios & Exemplos & $\begin{array}{l}\text { Quantidade } \text { de } \\
\text { termos } \\
\text { metafóricos para } \\
\text { cada um dos } \\
\text { conceitos } \\
\text { estabelecidos }\end{array}$ & Porcentagem (\%) \\
\hline $\begin{array}{ll}\text { Náutica } & \text { ou } \\
\text { movimentos } & \text { da } \\
\text { água } & \end{array}$ & $\begin{array}{l}\text {. flutuação } \\
\text {. flutuação cambial } \\
\text {. flutuação da } \\
\text { economia } \\
\text {. flutuação da taxa } \\
\text { de câmbio (entre } \\
\text { outras) } \\
\text {. câmbio flutuante } \\
\text { (entre outras) } \\
\text {. emergente } \\
\text {. mercado } \\
\text { emergente }\end{array}$ & 26 & $\begin{array}{l}0.9 \\
0.5\end{array}$ \\
\hline
\end{tabular}




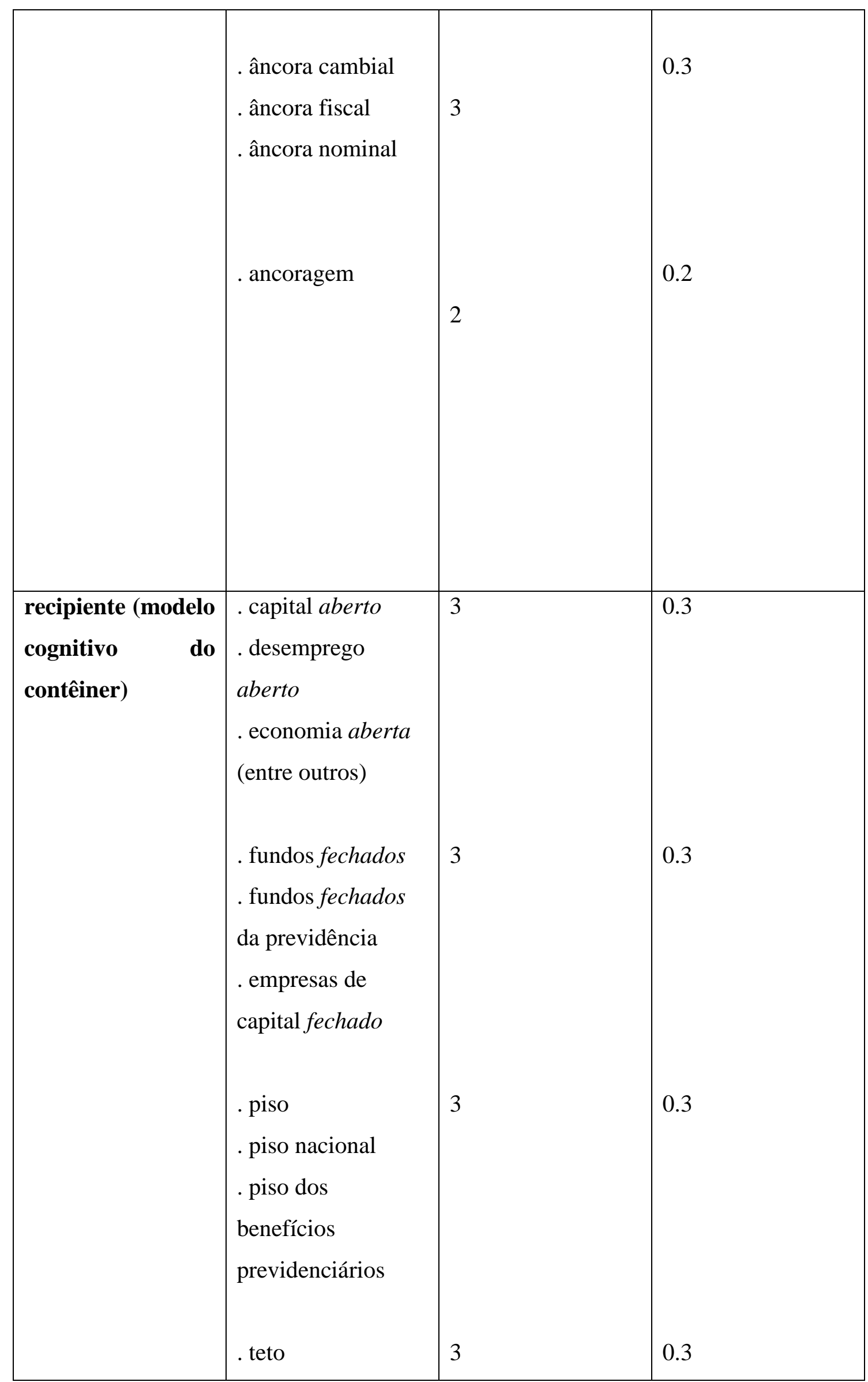




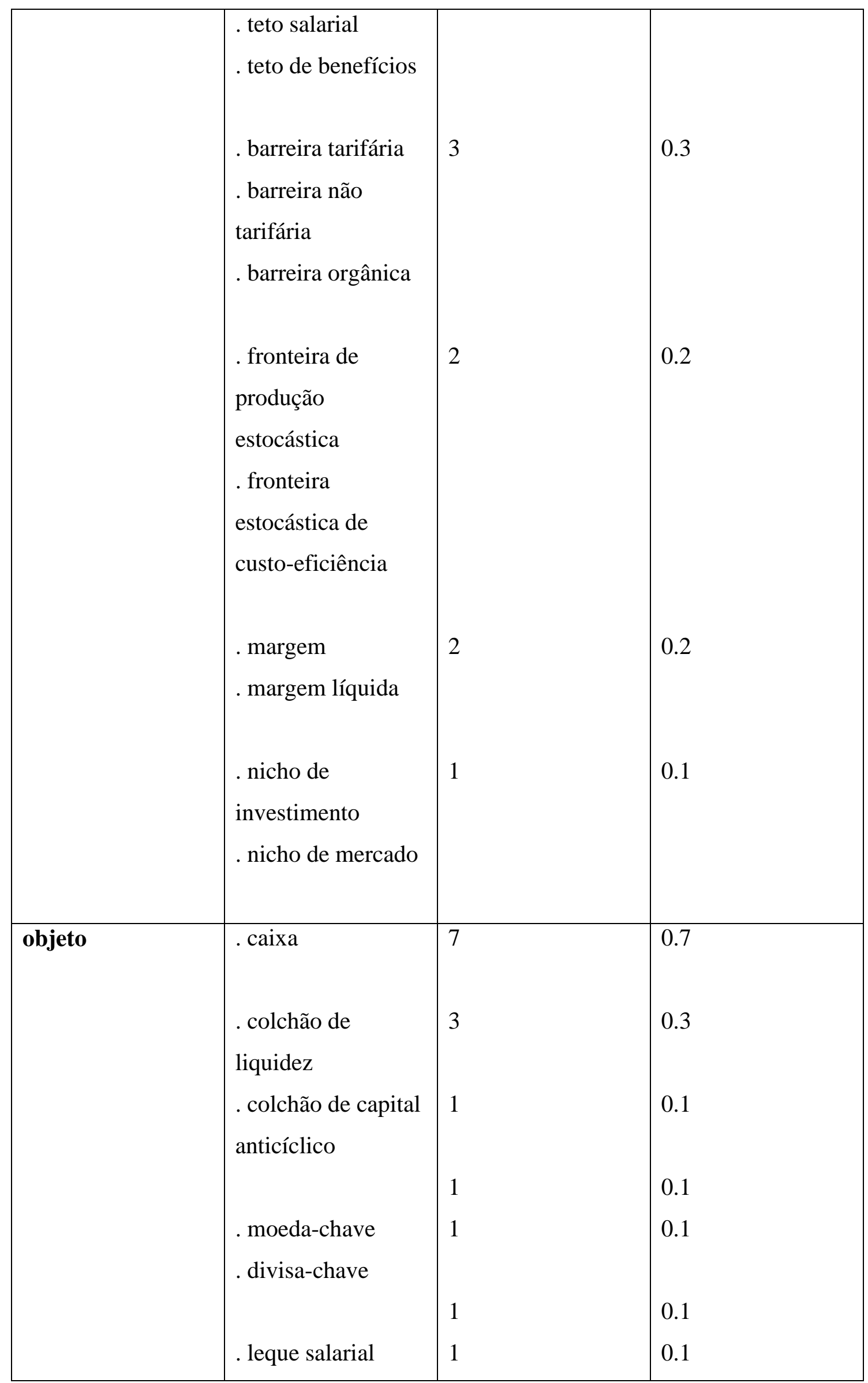




\begin{tabular}{|c|c|c|c|}
\hline & . leque de ativos & & \\
\hline belicismo & $\begin{array}{l}\text { - guerra comercial } \\
\text {. guerra de preços } \\
\text {. guerra fiscal } \\
\text {. guerra de moedas } \\
\text {. ataque } \\
\text { especulativo } \\
\text {. ataque de } \\
\text { autorrealizáveis } \\
\text {.estratégia de } \\
\text { desenvolvimento } \\
\text { nacional } \\
\text {. exército industrial } \\
\text { de reserva } \\
\text {. ativos defensivos }\end{array}$ & 4 & $\begin{array}{l}0.1 \\
0.1\end{array}$ \\
\hline $\begin{array}{l}\text { máquina } \\
\text { mecanismo }\end{array}$ & $\begin{array}{l}\text {. motor da } \\
\text { economia } \\
\text {. motor do } \\
\text { crescimento } \\
\text { econômico } \\
\text {. motor financeiro } \\
\text {. rolagem de } \\
\text { dívidas } \\
\text {. rolagem das } \\
\text { dívidas públicas }\end{array}$ & 2 & 0.2 \\
\hline
\end{tabular}




\begin{tabular}{|c|c|c|c|}
\hline & $\begin{array}{l}\text {.turbulência } \\
\text { financeira } \\
\text {.turbulência dos } \\
\text { mercados } \\
\text { financeiros }\end{array}$ & & \\
\hline zoomorfia & $\begin{array}{l}\text {. tigres } \\
\text { tigre asiático } \\
\text { t tigre celta } \\
\text { t tigre de primeira } \\
\text { geração } \\
\text {. tigre de segunda } \\
\text { geração }\end{array}$ & 5 & 0.5 \\
\hline higiene & $\begin{array}{l}\text {. flutação suja } \\
\text {. flutuação limpa } \\
\text {. regime de } \\
\text { flutuação suja } \\
\text {. lavagem de } \\
\text { dinheiro }\end{array}$ & 3 & $\begin{array}{l}0.3 \\
\\
0.1 \\
\\
\end{array}$ \\
\hline $\begin{array}{l}\text { regiões } \\
\text { geográficas } \\
\text { (variações de } \\
\text { altitude) }\end{array}$ & $\begin{array}{l}\text { pico } \\
\text { pico de renda } \\
\text {. depressão } \\
\text { econômica } \\
\text {. Grande Depressão }\end{array}$ & 2 & $\begin{array}{l}0.2 \\
0.2\end{array}$ \\
\hline artefato & $\begin{array}{l}\text {. armadilha de } \\
\text { liquidez } \\
\text {. armadilha de } \\
\text { renda média }\end{array}$ & 3 & 0.3 \\
\hline
\end{tabular}




\begin{tabular}{|c|c|c|c|}
\hline & $\begin{array}{l}\text {. armadilha de } \\
\text { lucratividade }\end{array}$ & & \\
\hline jogo & $\begin{array}{l}\text {. jogo financeiro } \\
\text { Teoria dos Jogos } \\
\text {. jogo de mercado }\end{array}$ & 3 & 0.3 \\
\hline violência & $\begin{array}{l}\text {. estrangulamento } \\
\text { cambial } \\
\text {. estrangulamento } \\
\text { externo }\end{array}$ & 2 & 0.2 \\
\hline arbitragem & $\begin{array}{l}\text {. arbitragem } \\
\text {.arbitragem } \\
\text { regulatória }\end{array}$ & 2 & 0.2 \\
\hline religião & $\begin{array}{l}\text { paraíso fiscal } \\
\text { fetichismo da } \\
\text { mercadoria }\end{array}$ & 2 & 0.2 \\
\hline escape & . fuga de capitais & 1 & 0.1 \\
\hline dança folclórica & . ciranda financeira & 1 & 0.1 \\
\hline \multirow[t]{2}{*}{ estado civil } & $\begin{array}{l}\text {. descasamento de } \\
\text { moedas }\end{array}$ & 1 & 0.1 \\
\hline & & $\begin{array}{l}\text { Total de termos } \\
\text { metafóricos da } \\
\text { Tabela } 4=122\end{array}$ & \\
\hline
\end{tabular}




\section{ANÁLISE DAS METÁFORAS CONCEITUAIS DA ECONOMIA}

Após a apresentação dos domínios cognitivos no tópico anterior, faremos a seguir a análise desses conceitos. Em primeiro lugar, antes de dar início a essa fase, precisamos reafirmar que a metáfora é construída através de uma relação imediata e interna com uma experiência passada específica. De acordo com Oliveira (2009, p. 72), essas experiências realizam-se a partir de quatro modalidades: sensação, percepção, representação e denominação. Deduz-se que todo conhecimento deriva dos sentidos da experiência, proporcionando-nos a aprendizagem, cujo empirismo repousa na múltiplas memórias do mesmo fenômeno, de forma que, no caso do conhecimento científico, o especialista repousa em suas reminiscências as estruturas conhecidas, retidas de sua vida cotidiana, recuperando essas informações antigas estocadas na memória que ele ativa parcialmente para resolver um problema ou construir um conhecimento. A experiência que o especialista tira de seu ambiente é fundamental para a compreensão das experiências mais abstratas. Apoiando-se no empirismo, a ciência elabora as representações metafóricas; o especialista necessita de uma imagem visual para descrever uma forma baseada em nossas experiências corporais e sensoriais para denominar o objeto da descrição.

Neste trabalho, categorizamos essas imagens projetadas pelos especialistas na atividade de denominação dos conceitos, levando em consideração esses processos de experienciação pela metáfora. No universo da Economia, os empregos metafóricos são provenientes de campos diversos, porém, de acordo com os dados tabulados, observamos que uma parte expressiva desses termos faz referência aos campos da Física e da Biologia.

No discurso científico da Economia, as metáforas terminológicas são estabelecidas por meio de uma relação de semelhança entre conceitos desses domínios diversos, um domínio-fonte e um domínio-alvo. Nessa área de conhecimento, os cientistas valem-se do campo da Física por razões até mesmo históricas, ligadas ao cientificismo vigente no período em que a Economia se estabeleceu como ciência. A Biologia, também por essas mesmas razões, é um domínio bastante recorrente pelo fato de ela ser compreendida sobremaneira como um "organismo", conforme podemos observar na Tabela 2 proposta no capítulo anterior. Se a Economia funciona como um "organismo", ela pode crescer (crescimento econômico), amadurecer (economias maduras) e adoecer, tendo crises e colapsos (crise de liquidez e colapso financeiro). 
Na Física, conceitos relacionados à fluidez, impacto, elasticidade, velocidade e temperatura $^{56}$ são predominantes em nosso corpus de estudo. Esses dados nos permitem afirmar que a Economia funciona por meio de funções de ordem "natural". Muitos desses conceitos revelam que ela deve se movimentar a fim de gerar "desenvolvimento" em sociedades capitalistas, cujo objetivo final é o enriquecimento.

Em relação às orientacionais, são muitos os domínios reveladores de que aquilo que é bom é "para cima", e o que é ruim é "para baixo". Esse é o caso de "alta", momento em que as ações com uma boa cotação apresentam uma elevação significativa de preços, e "baixa", movimento contrário a esse. Esses dois termos são encontrados no Dicionário de economia do século XXI de Sandroni (2005), ${ }^{57}$ no qual foram incorporados 1.500 verbetes à edição anterior, de 1999. Em relação às noções de "fundo" e "raso", a unidade fundo é muito produtiva (mais de 100 termos), ao passo que para a noção de raso não há ocorrência. Também há alguns termos relacionados a noções de central e periférico, tal como espiral inflacionária. Existem outros exemplos, como desverticalização da produção, no qual "verticalização" também conceitua a ideia de que aquilo que é bom é "para cima".

Outros domínios-fonte apresentados na Tabela 4 chamam nossa atenção também pela sua produtividade. Eles estão relacionados à "náutica ou a movimentos da água” (tais como "flutuação"), "guerra" (exemplificado por guerra comercial), e a objetos como "colchão" (como no exemplo colchão de capital anticíclico) e "chave" (em moedachave) ${ }^{58}$ Esses e outros conceitos revelam a tendência à diversificação das metáforas da Economia, que vão além dos limites da Física e da Biologia, mas que de alguma forma podem retomar projeções atinentes à Física, como "flutuação", uma vez que se refere a um "corpo" que é mantido à superfície de um líquido, cujo conceito é empregado na Economia para descrever mudanças no câmbio (explicando a "oscilação" das moedas, cuja cotação varia conforme o movimento do mercado). Por isso, a analogia é estabelecida entre o movimento de oscilação que faz um "corpo" flutuar e a cotação de uma moeda, cuja cotação é instável e sujeita a movimentos do mercado.

\footnotetext{
${ }^{56}$ Em Termologia, área estudada também pela Física, "trabalho" pode ser transformado em "calor". A temperatura é uma grandeza que caracteriza o equilíbrio térmico de um sistema entre que possa haver passagem de "calor" de um sistema para outro (MACEDO, 1981, p. 333).

${ }^{57}$ Ganhador do prêmio Jabuti em 2000.

${ }^{58}$ Esses termos também podem ser interpretados como metonímicos do tipo "símbolo pelo simbolizado".
} 
Nessa mesma Tabela 4, nota-se também que há dois termos que estabelecem relações com o domínio-fonte do contêiner, ${ }^{59}$ tais como "piso" e "teto" empregados na descrição de preço (ou valor) mais baixo e mais alto, respectivamente. No caso desses termos, os conceitos apresentados não se referem à ideia de habitação ("piso" no sentido do chão da casa, ou "teto", a parte mais alta de uma residência).

Em ECONOMIA É MÁQUINA, ainda na Tabela 4, identificamos os termos motor do crescimento e/ou motor do crescimento econômico, em que se conceitua a Economia de desempenho ótimo como aquela capaz de funcionar como uma máquina.

Em relação aos termos relacionados à "alavancagem”, Beber Sardinha (2007) considera-os também como o domínio-fonte da máquina, uma vez que para o autor a “alavancagem" é realizada por meio de uma "máquina" - no caso, uma alavanca. Porém, para essa análise proposta em nossa tese, consideramos a alavancagem como um processo físico, pois se trata de um tipo de força que é usada para levantar algum objeto de forma fácil.

Também é importante notar que encontramos em alguns termos conceitos que se intercruzam, como, por exemplo, crescimento líquido. Em "crescimento", observamos o processamento metafórico em termos de organismo oriundo da Biologia; em "líquido" também há ocorrência de uma metáfora por analogia à Física.

Após a realização dessas considerações iniciais sobre os traços conceptuais presentes nos termos aqui analisados e agrupados em domínios de experienciação, iremos primeiramente comentar de que forma os dois principais conjuntos de termos da Economia comportam-se. Para realizarmos tal tarefa, recorremos a Ajzental (2015) para definirmos inicialmente esses dois campos referentes à Física e à Biologia, para posteriormente estabelecermos correlações entre essas duas áreas de conhecimento e a Economia. Em seguida, iremos descrever e analisar as formações terminológicas metafóricas que ocorreram em nosso corpus a respeito de suas motivações comunicativas, linguísticas e cognitivas presentes nessas formações, levando-se em conta o arcabouço teórico que enviesou este tipo de estudo.

\footnotetext{
${ }^{59}$ A metáfora do contêiner é denominada por Lakoff e Johnson (2002, [1980]) como a metáfora do recipiente. Berber Sardinha (2008) refere-se a esse tipo de conceito como receptáculo. Ele consiste em projetar a nossa própria orientação dentro-fora sobre outros objetos físicos que são delimitados por superfícies. Para Lakoff e Johnson (2002, [1980], p. 81) cada um de nós é um recipiente com uma superfície demarcadora. A compreensão como contêiner serve cognitivamente como base estruturante para outros conceitos.
} 


\subsection{A Física como campo de conhecimento ${ }^{60}$}

Para Ajzental (2015), a fim de que se possa visualizar com maior facilidade e clareza os conceitos presentes na Economia, torna-se necessário conhecer a evolução da Física desde a Grécia antiga, passando pela Física mecânica e Termodinâmica, até chegar à Física estatística.

O marco inicial do estudo da Física no Ocidente está associado às teorias do movimento propostas por Aristóteles, as quais influenciaram profundamente os pensadores seguintes e continuariam sendo aceitas ao longo de mais de 1.500 anos, até serem substituídas por avanços propostos pelo físico inglês Isaac Newton (1643 - 1727). A partir dos estudos de Newton, noções propostas por Aristóteles - como e de que a terra se movimentava em linha reta, por exemplo - provaram-se incorretas, sendo substituídas por novas noções básicas de força e massa que gerariam um grande avanço na teoria do movimento do planeta.

A mecânica de Newton projeta uma das principais características extraordinárias das leis da Física, que é a sua capacidade de se prever o futuro. Porém, a posteriori descobriu-se que nem todos os seus pressupostos eram completamente verdadeiros. Afirmava-se que se conhecidas a massa, as velocidades e a trajetória todos os objetos poderiam ter suas posições determinadas, contudo esse princípio apresentado por Newton é contestado em 1927 por Heisenberg, o qual determinou o "princípio da incerteza" na Mecânica Quântica, ao afirmar que não é possível medir os valores exatos da posição e do momento (massa $\mathrm{x}$ velocidade) de uma partícula ao mesmo tempo.

Outra noção importante para a Física citada por Ajzental $(2015$, p. 30) é a da termodinâmica. Até o final do século XVIII, os físicos consideravam a existência de apenas dois tipos distintos de entidades na constituição do universo: a matéria (sólidos, vapores e líquidos) e energia (calor, luz e som). Contudo, nas primeiras décadas do século

\footnotetext{
${ }^{60}$ Segundo o Instituto de Física da USP em São Carlos, as principais áreas da Física são Mecânica (Cinemática, Dinâmica, Estática, Hidrostática, Hidrodinâmica, Aerostática e Aerodinâmica), Termologia (Termodinâmica e Calorimetria), Ondulatória, Acústica, Ótica, Eletromagnetismo (Magnetismo, Eletricidade e Física de Semicondutores), Física Moderna, Teoria da relatividade (Relatividade geral e Relatividade restrita), Física de Partículas (incluindo Física Subatômica), Física Atômica, Física Molecular, Física Nuclear, Mecânica Quântica e Mecânica Estatística. Entre suas aplicações tecnológicas estão a Eletrônica e Física computacional. Havendo ainda as áreas de Física de Materiais, Mecânica Estatística, Física Matemática, Física de Plasmas, Oceanografia, Econofísica e Física Atmosférica e aplicações em outras ciências, como Físico-química (na Química), Astrofísica (na Astronomia), Geofísica (na Geologia), Biofísica (na Biologia), Física Médica (na Medicina) e Agrofísica (na Agronomia).
} 
XIX, o cientista francês Nicolas Carnot (1796 - 1832) - tido hoje como "o pai da termodinâmica" -, propõe um terceiro elemento: a "entropia", ou medida de energia, o qual passa então a ser considerado nas relações físicas universais, e cuja ação futuramente receberia estudos estatísticos.

Para Ajzental (2015, p. 19), muitas metáforas da Economia vêm da Física clássica. Esse autor cita o caso da teoria Microeconômica neoclássica, mas só fornece um exemplo de termo, "fluxo circular de renda", utilizado na Macroeconomia.

Em nosso corpus de estudo, esses domínios-fonte referem-se a conceitos da Física com seus mecanismos de preços; EQUILÍBRIOS e ELASTICIDADES, geradores de termos como motor de crescimento, balanço e elasticidade e elasticidade-renda das exportações. As projeções metafóricas relacionadas a equilíbrio dizem respeito a um dos grandes problemas da Economia, que é o de resolver esse tipo de problema, cujo paradigma de organização tem sido a ideia de que ela é um sistema de equilíbrio (um sistema de repouso), e, por isso, muitos termos metafóricos revelariam esses conceitos.

\subsection{A Biologia como campo de conhecimento}

Há uma forte tendência de metáforas evolucionárias da Biologia na Economia.

(Ajzental, 2015, p. 165)

Outro ponto de contato marcante entre a Economia e outras ciências responsáveis pelas metáforas dessa área de conhecimento é o da Biologia. No século XIX, sabemos que existia uma relação próxima entre fenômenos sociais e biológicos. Nesse período, fenômenos socioeconômicos eram explicados por muitos especialistas por meio da Biologia. É o que fez Malthus, influente economista inglês do final do século XVIII e início do século XIX, ao apresentar um estudo sobre crescimento populacional, oferta e demanda total de alimentos em relação ao desenvolvimento na Economia a longo prazo (AJZENTAL, 2015, p. 166):

Malthus foi provavelmente o primeiro a demonstrar o poder do feedback, sugerindo ainda que qualquer interpretação da economia clássica como um simples modelo newtoniano seria equivocada. Tinha como arcabouço teórico extensões agregadas, argumentando que as taxas médias de alteração na oferta e na demanda total de alimento, definidas como população versus consumo médio, determinariam desenvolvimento de uma economia em longo prazo. 
Nesse contexto da forte influência da Biologia exercida sobre a Economia, devemos citar o norte-americano Thorstein Bunde Veblen (1857 - 1929), autor do termo “economia evolucionária", apresentado em seu artigo publicado em 1898 "Why is Economics not an Evolutionary Science?", 61 conhecido como o início da economia evolucionária "pós-darwinista".

Outro nome importante para entender de que forma o pensamento biológico influenciava a teoria econômica é o de Herbert Spencer $(1820$ - 1903) e sua abordagem biológica reducionista: "Para ele, as explicações dos fenômenos sociais eram reduzidas ao indivíduo e, a partir de então, a termos biológicos”. Spencer era adepto das explicações lamarckistas, "ressaltando mais a adaptação do organismo ao ambiente do que a seleção ambiental dos organismos" (Azjental (2015, p. 166-7). Esse economista comparava a sociedade a um organismo vivo em termos mecânicos e, portanto, podemos dizer que sua visão de uma evolução socioeconômica era de caráter individualista, determinista e reducionista.

Porém não foi somente a Biologia que deixou a sua influência na Economia. $\mathrm{O}$ inverso disso também aconteceu, conforme veremos a seguir.

\subsubsection{A influência da Economia na Biologia}

A influência da Economia na Biologia também deixou os seus rastros. De acordo com Ajzental, Charles Darwin afirmava que a sua inspiração para a lei da seleção foi o Ensaio do princípio da população, de Malthus, publicado em $1798 .^{62}$ Resumidamente, esse texto propunha que o crescimento populacional leva à competição por alimentos e outros recursos. Logo, deveria haver algum mecanismo que deixaria a população de determinada espécie em equilíbrio em relação ao seu habitat e à quantidade de alimento disponível. Darwin, então, adaptou essas ideias para explicar a evolução dos organismos vivos perante uma incessante "luta pela existência", apresentando em Biologia o

\footnotetext{
${ }^{61}$ Essas informações podem ser encontradas em Ajzental (2015, p. 166-7).

${ }^{62}$ Conforme diz Ajzental (2015, p. 49), Darwin também leu A riqueza das nações de Adam Smith, trabalho em que é exposto o conceito da "mão invisível" na Economia, o qual consiste na ideia de que um grupo de indivíduos, que age por interesse próprio, com o objetivo de maximizar algum benefício para a sua comunidade.
} 
significado de evolução, seleção ou população, o que para Ajzental (2015, p. 63) são conceitos fornecedores de uma rica fonte para a criação de termos (por exemplo, crescimento econômico), a seguir descritos:

- variação: os mecanismos cegos ou aleatórios para que ocorra diferenciação entre os indivíduos de uma determinada população;

- seleção: as variantes mais aptas em determinado meio têm maior probabilidade de que as suas características sejam transmitidas às gerações posteriores;

- herança: as características dos indivíduos mais bem-adaptadas podem ser transmitidas aos seus descendentes.

Essa perspectiva darwinista atingiu várias áreas de conhecimento: economia evolucionária, psicologia evolucionária, antropologia evolucionária, linguística evolucionária, ciências da computação, algoritmos genéticos e computação evolucionária.

Em Economia, o darwinismo universal pode ser aplicado em economia evolucionária, ciência que estuda várias e importantes categorias como commodities, tecnologia, comportamento econômico, instituições, organizações, sistemas e conhecimento. A economia evolucionária compreende a "concorrência" entre empresas e instituições como um processo de "sobrevivência do mais bem adaptado".

\subsection{Análise dos traços conceptuais da Economia e seus respectivos domínios-fonte}

Nesta seção, demonstraremos e comentaremos exemplos dos termos metafóricos deste corpus de análise levando em consideração os dados das tabelas apresentados no Capítulo 6, dividindo-os em campos da Física, da Biologia, das Metáforas Orientacionais e de Outros Domínios.

$\underline{\text { As metáforas da Física apresentadas na Tabela } 1}$ 


\title{
a) instantaneidade
}

O primeiro conceito mais produtivo é o relacionado à "instantaneidade", denominando termos como liquidez. O conceito apresentado no domínio-fonte ECONOMIA É INSTANTANEIDADE ou ECONOMIA É LIQUIDEZ, expresso em mais de 117 metáforas, corresponde a 14\% do total das unidades metafóricas. A metáfora da liquidez, que conceitua a Economia em termos de "instantaneidade", pode ser compreendida como algo que pode ser convertido em moeda corrente rapidamente. A metáfora da liquidez aqui manifesta-se em termos como liquidez financeira, conforme podemos observar a seguir:

\begin{abstract}
O constrangimento de <liquidez> é um aspecto geral e inerente à decisão de investimento, 'que envolve todas as modalidades de formação de nova riqueza real: capital fixo, circulante e líquido' (op. cit.). Apesar de outras fontes serem passíveis de cumprir o finance, os bancos, por intermédio do multiplicador bancário, apresentam características próprias que os tornam agentes capazes de atuar diretamente sobre este mecanismo. A preferência pela <liquidez> não se manifesta necessariamente pela retenção de moeda strictu senso ou por depósitos à vista. Estes podem ser substituídos por ativos de curtíssimo prazo e de <liquidez> elevada, que podem incluir instrumentos de captação bancária de baixa carência - 21 operações compromissadas - ou títulos públicos de elevada liquidez. No capítulo 2 serão detalhados os aspectos específicos que a preferência pela liquidez assume quando existem <ativos de alta liquidez> e com capacidade de assumir o lugar da moeda em sua forma estrita, como é o caso do Brasil. [...].(BASTOS, H. G. O papel dos fundos de pensão da formação do funding no Brasil, 2015).
\end{abstract}

A liquidez também pode ser compreendida como um fenômeno físico, pois nesse domínio-fonte este conceito vincula-se, por exemplo, à ideia de "instantaneidade", uma vez que o estado líquido é uma condição da matéria em que a distância entre suas moléculas é suficiente para se adequar a qualquer meio, garantindo assim a sua fluidez. Os traços semânticos que definem esse referente na Economia, projetados pelo domíniofonte para o domínio-alvo, são oriundos de acepções do tipo "qualidade ou condição de um corpo no estado líquido; fluidez". 63

Em Economia, esses aspectos da "fluidez" e da "instantaneidade" revelam a disponibilidade em moeda corrente, meios de pagamento, ou posses de títulos ou de valores conversíveis rapidamente em dinheiro (SANDRONI, 2005). No exemplo acima, o termo metafórico ativos de alta liquidez, a metáfora da liquidez refere-se a ações que podem ser consideradas ativos de alta liquidez, expressando a situação em que um investidor consegue converter rapidamente esses papéis em dinheiro.

\footnotetext{
${ }^{63}$ Definição dada pelo Dicionário Houaiss da língua portuguesa, 2001, p. 1768.
} 
Do ponto de vista linguístico, localizamos no corpus da Economia não somente a sua forma simples como também, mais comumente, seu desdobramento em formações sintagmáticas, a exemplo de <ativos de alta liquidez>. Nesse termo, liquidez é precedida pelo sintagma preposicionado adjetival $\langle$ de alta $\rangle$, o que nos leva a considerar que a forma simples liquidez é empregada na conversão de "líquido" para o substantivo liquidez, assumindo dessa forma majoritariamente a função de adjetivo em suas formações sintagmáticas, tais como: ativos de alta liquidez, liquidez financeira, ciclos de liquidez e liquidez de curto prazo, entre outros. A metáfora "liquidez" especifica um tipo de ativo cuja conversão em dinheiro é realizada rapidamente. O núcleo "ativo", que é um elemento genérico, refere-se diretamente ao objeto que designa, e apenas o adjunto liquidez é usado metaforicamente, tornando, dessa forma, o significado do termo bastante transparente.

\section{b) impacto}

No campo da Física, o segundo conceito mais produtivo é o relacionado a "impacto" denominando termos como choque. O conceito expresso no domínio-fonte ECONOMIA É CHOQUE ocorre em mais de 64 metáforas, corresponde a 7.4\% do total de metáforas. O termo choque significa o esforço total de lançar a política econômica em um de seus objetivos, deixando de lado os demais. Um choque econômico, por exemplo, é a liberalização de um mercado estatal para estimular a Economia após, por exemplo, um período de guerra. Com 23 registros em nosso corpus de estudo, um choque de oferta pode ser compreendido, de acordo com Sandroni (2005, p. 140), como um fenômeno que ocorre quando a curva de oferta se desloca para a direita ou para a esquerda devido, por exemplo, à descoberta de jazidas de matérias-primas, mudanças tecnológicas e rupturas significativas de safras, causando um desequilíbrio em relação à demanda, e, portanto, uma acentuada alteração de preços. Vejamos a seguir um dos contextos em que esse termo aparece:

O governo deve anunciar o porcentual do <choque de oferta> que deve ser combatido em aquele período, com a ressalva estratégica de que não anulará plenamente os efeitos do choque na inflação de curto prazo, mas eliminará os impactos secundários na tendência da inflação. Svensson (1997) afirma que o ajuste gradual da inflação à meta de inflação de longo prazo é mais apropriado para aliar a minimização das flutuações do produto à manutenção da inflação baixa e estável. (GIAMBIGI, F.; MATHIAS, A.; VELHO, E. $O$ aperfeiçoamento do regime de metas de inflação no Brasil, 2006) 
Esse termo pode ser compreendido como um conceito de origem na Física vinculado à ideia de "impacto", pois em Física, qualquer interação entre partículas ou corpos rígidos que estejam suficientemente perto normalmente resulta em troca de energia e colisão. Os traços semânticos que permitem a definição desse referente na Economia, transportados pelo domínio-fonte para o domínio-alvo, são oriundos das acepções apresentadas pelo Dicionário Houaiss (2001, p. 704) relativas a "encontro violento, com abalo brusco, entre corpos em movimento; colisão, concussão". Logo, esse domínio-fonte é bastante produtivo em Economia, pois estabelece analogias com situações nessa área em que uma medida de impacto poderá trazer benefícios ao equilíbrio econômico. Para Ajzental (2015, p. 180), a única maneira de interromper ou perturbar a evolução da Economia é por meio de um choque externo ocasionando novo equilíbrio.

\section{c) dissipação}

O terceiro conceito em Economia relacionado ao campo da Física é ECONOMIA É DISSIPAÇÃO, capaz de cunhar termos como volatilidade e bolha. São no total 50 formações (32, ou seja, 3,7\% termos metafóricos gerados a partir da unidade volatilidade e 18, 2\%, a partir de bolha). A volatilidade expressa uma medida das oscilações nos preços de um ativo (ações, títulos, entre outros tipos de investimento). O investidor pode, por meio dessa medida estatística, ter uma estimativa da variação de preço de um título no futuro. Esse ativo "volátil" pode ser um fator de risco para um investidor, uma vez que se corre risco de não se obter os lucros almejados. Do ponto de vista da Física, volatilizar é "fazer passar ou passar ao estado de gás ou vapor; reduzir-se a gás ou vapor, vaporizar $(-\mathrm{se}) " \cdot 64$

Em nossa análise, compreendemos que a analogia estabelecida entre os dois domínios ocorre pelo fato de os ativos sofrerem oscilações, passando de um preço para outro, evidenciando o grau de dispersão das variações ocorridas no preço desses investimentos, o que em Física (domínio-fonte) demonstra a capacidade de passagem de uma substância que se encontra em um estado para outro, revelando seu caráter de algo "volúvel", o que na Economia (domínio-alvo) demonstra a possibilidade de um ativo oscilar (o que tinha um valor x passa a ter um valor y), ou de ter o seu valor reduzido.

\footnotetext{
${ }^{64}$ Dicionário HOUAISS da língua portuguesa, 2001, p. 2879.
} 
Em "bolha", a Economia é tratada como se fosse uma parte da natureza, algo físico sujeito a inchaços anormais que, estourando, causa danos ao crédito em geral. De acordo com Jennifer Rocha Vargas Fogaça, ${ }^{65}$ na Física química as "bolhas" acontecem quando se leva em consideração a força intermolecular de hidrogênio cujas ligações ocorrem na água pela atração do polo positivo de uma molécula (hidrogênio) com o polo negativo de outra (oxigênio). Elas se formam devido à intensidade da tensão superficial que existe entre as moléculas que estão na superfície da bolha, realizando ligações de hidrogênio somente com moléculas ao seu lado, aumentando a força dessa ligação. Para diminuir essa superfície ao mínimo, a bolha adquire um formato com a menor relação entre área superficial e volume, que é a forma esférica. As moléculas do detergente, por exemplo, interpõem-se às moléculas de água. Portanto, sua elasticidade resulta da interação entre as moléculas de água restantes; contudo, quando essas moléculas se evaporam, a bolha consequentemente estoura; ou seja, ela se dissipa. Logo, na Economia, a analogia entre bolha e dissipação acontece quando um ativo apresenta um valor maior do que o real, fazendo com que as pessoas percebam em um determinado momento que o seu valor não mais se sustenta, levando assim ao ponto de sua dissipação - ou, como é referido mais comumente, sua explosão -, criando uma rápida desvalorização que obriga os investidores a saírem do negócio.

A seguir, dois contextos em que esses termos são extraídos deste corpus de análise (no exemplo 1, volatilidade; no 2, bolha):

\section{Exemplo 1}

Os resultados apresentados neste artigo revelam que países com uma economia informal expressiva tendem a apresentar flutuações mais acentuadas na atividade econômica. A conexão entre o tamanho da economia informal e a <volatilidade > dos ciclos econômicos pode ser estabelecida teoricamente como uma extensão da literatura que avalia o funcionamento dos mercados financeiros em condições de informação assimétrica. (TIRYAKI, G. F. A informalidade e as flutuações na atividade econômica, 2008)

\section{Exemplo 2}

A 'imunidade' dos intermediários financeiros - dadas as hipóteses do modelo - é o elemento responsável pela criação de uma <bolha especulativa〉. O 'estouro da <bolha〉', ou seja, o processo de deflação de ativos, é gerado nos momentos posteriores quando os resultados de rentabilidade dos ativos passam a não corresponder aos valores esperados pelos intermediários, o Pangloss value. Como estes não são de fato garantidos pelas

65 Disponível em: <https://mundoeducacao.bol.uol.com.br/quimica/como-se-formam-as-bolhassabao.htm>. Acesso em 19 jul. 2019. 
autoridades monetárias, os resultados negativos passam a ser repassados para os aplicadores. Estes, por sua vez, tendo em vista os resultados, passam a retirar sua riqueza dos intermediários (desintermediação) e comprar os ativos no mercado por sua rentabilidade esperada. (CURADO, M. Flutuações nos preços dos ativos: uma comparação entre as bolhas especulativas racionais e a contribuição keynesiana, 2006)

\section{d) equilíbrio}

O quarto conceito mais produtivo é o do equilíbrio, formando praticamente $4 \%$ dos termos. Esse domínio-fonte empregou um tipo de referente que se prestou a denominar termos como balanço e balança do qual derivam 34 formações (3,3\% termos metafóricos gerados a partir da unidade balanço e 0,6\% a partir de balança), tais como balanço, balanço financeiro e balanço de transações correntes; balança, balança comercial e balança de serviços. Essa unidade terminológica é conceituada em Economia em termos de "equilíbrio", uma vez que uma das grandes questões dessa área de conhecimento é resolver seu problema de “equilíbrio". De acordo com Sandroni (2005, p. 58), esse termo refere-se ao levantamento contábil que demonstra a situação econômico-financeira de uma empresa, agrupando os saldos credores e devedores de uma empresa em certo período. No caso de balança comercial, por exemplo, o termo se refere à relação entre as exportações e as importações de um país. A seguir, apresentamos alguns desses termos contextualizados (no exemplo 1, balanço; no 2, balança):

\section{Exemplo 1}

Uma última conclusão importante é que, ao contrário do que seria de se esperar com base no senso comum, um aumento da taxa básica de juros produz uma redução do spread bancário. Isso ocorre porque um aumento da taxa de juros dos títulos do governo irá induzir o banco a aumentar a sua posição defensiva líquida. Para tanto, ele terá que aumentar o volume do capital de terceiros no seu 〈balanço>, de forma a obter mais recursos para financiar a aquisição de ativos defensivos. (OREIRO, J. L. Preferência pela liquidez, racionamento de crédito e concentração bancária: uma nova teoria pós-keynesiana da firma bancária, 2005)

\section{Exemplo 2}

Nos Estados Unidos, a política industrial é ativa e protagonista, em que pesem as visões não intervencionistas tão difundidas, e não acompanha as políticas industriais dos demais países, mas é concebida e implementada para enfrentar problemas e resolver desafios de uma realidade nacional e de uma posição geopolítica muito distinta. A <balança comercial> dos EUA, apesar de ser sistematicamente deficitária, em volumes crescentes há mais de dois decênios, constitui um não-problema para a política econômica estadunidense. O papel do dólar como moeda internacional e como reserva de valor da maior parte dos 
países permite que o país não apenas conviva com déficits comerciais, como, ademais, torne todos os países sócios estratégicos desses déficits comerciais uma situação singular no cenário internacional. Se existe algo que possivelmente traria grandes perturbações às relações econômicas internacionais e acentuaria os seus desequilíbrios seria uma política destinada a reverter esses déficits. (SUZIGAN, W; FURTADO, J. Instituições e políticas industriais e tecnológicas: Reflexões a partir da experiência brasileira, 2010)

A "balança", de acordo com Houaiss (2001, p. 382), pode referir-se a qualquer instrumento ou aparelho destinado a comparar massas, determinar pesos ou medir forças, com o sentido figurado significa "equilíbrio". "Balanço", de acordo com o mesmo autor (2001, p. 383), é um deslocamento alternado de um corpo em relação ao seu centro de equilíbrio. Esses dois conceitos físicos têm um significado comum que é o "equilíbrio", os quais constituem o domínio-fonte dessa metáfora em Economia, pois, conforme já comentamos anteriormente, o objetivo principal da Economia é encontrar equilíbrio em suas transações.

\section{e) flexibilidade}

O quinto conceito mais produtivo é o da flexibilidade, formando quase $3 \%$ das unidades terminológicas estudadas. Esse domínio-fonte empregou, por exemplo, um tipo de referente que serviu para conceptualizar esse tipo de projeção capaz de criar termos como elasticidade, elasticidade-preço e elasticidade-renda da demanda, da qual derivam 25 formações. A Economia passa então a ser compreendida nesse domínio em termos de "flexibilidade", uma vez que predomina nessa ciência a "hipótese mecanicista neoclássica, que enxerga a Economia como uma máquina, com mecanismos de preços, equilíbrios e elasticidades" (AJZENTAL, 2015, p. 22).

O termo elasticidade é definido por Sandroni (2005, p. 285-286) como a relação entre as diferentes quantidades de procura e de oferta de algumas mercadorias em função das alterações verificadas em seus preços. Os bens de demanda "elásticos" são aqueles indispensáveis à subsistência da população, cuja elevação do preço acarreta imediata diminuição da demanda. Do ponto de vista matemático, elasticidade funciona como uma medida da força de uma grandeza econômica tomada como variável. A seguir, um dos contextos em que essa metáfora terminológica ocorre em nosso corpus de estudo:

Passaremos, agora, à análise dos resultados das funções de produção. Note-se, em primeiro lugar, que as variáveis do modelo utilizado estão centradas em torno da média geométrica da amostra. Esse procedimento torna os 
coeficientes estimados mais robustos, pelo fato de a função translog ser uma aproximação de segunda ordem de qualquer função de produção arbitrária, em torno da média da amostra. Além disso, ele permite obter as <elasticidades> da produção em relação aos fatores de produção e a taxa de progresso técnico, avaliadas na média, diretamente das estimativas dos [...]. (TANNURIPIANTO; SOUSA; ARCOVERDE. Fronteiras de eficiência estocásticas para as empresas de distribuição de energia elétrica no Brasil: uma análise de dados de painel, 2009)

Para o Dicionário de Física de Macedo (1981, p. 111), “elasticidade” é uma noção oriunda da mecânica (parte da Física em que se investiga o movimento e suas causas) que implica a propriedade de um corpo cuja forma modifica-se pela ação de forças externas, mas que retorna à sua forma original quando termina a ação dessas forças, opondo-se à rigidez. Esse domínio-fonte é análogo ao domínio-alvo da Economia à medida em que ela se refere aos preços dos produtos que variam de acordo com as relações de oferta e de procura, conceituando essas alterações em termos de "flexibilidade" de preços ou como medida da força de uma grandeza econômica entendida como variável. O conceito da "elasticidade" em Economia explica que ela deve ser flexível para se ajustar a novas demandas no que se refere ao consumo.

\section{f) impulso}

Os termos da Economia que se referem à "alavancagem" conceituam uma compreensão física relacionada à "impulsão”, definida pela Física em termos de mecânica em que a "integralidade de uma força é estendida ao tempo" (MACEDO, 1981, p. 188). Esse domínio-fonte é responsável pelo sexto conceito mais produtivo em Economia, que é o do movimento do "impulso" realizado por meio da ação da "alavancagem", operação que faz uso de uma máquina - no caso, a alavanca - para a sua otimização. Esse domínio formou praticamente $2 \%$ das unidades terminológicas metafóricas empregadas, cujo referente gerou termos como alavancagem, alavancagem financeira e taxa absoluta de alavancagem.

Considerando se ainda que o nível desejado de dividendos depende do nível desejado de alavancagem e vice-versa, primeiramente estimamos as equações em suas formas reduzidas para eliminarmos os problemas de endogeneidade. Também modelamos as equações de ajustamento que capturam se dividendos e <alavancagem> tendem às respectivas metas. Utilizamos a abordagem de Fama e McBeth (1973), como sugerido em Fama e French (2002), que reporta as médias dos coeficientes de inclinação anuais estimados a partir de regressões seccionais. Para inferir as significâncias, calculam-se estatísticas t de Student pela divisão de cada coeficiente médio por seu desvio padrão 
amostral. (SILVA, J. C. G. da; BRITO, R. D. Testando as previsões de tradeoff $e$ pecking order sobre dividendos e dívida no Brasil, 2005)

Os conceitos aqui estabelecidos referem-se a processos econômicos em que a "impulsão" e a "alavanca" (compreendida aqui como "máquina") são positivos para a Economia, pois, de forma análoga, a Economia que funciona como uma máquina maximiza os lucros para os detentores do capital.

\section{g) aumento ou diminuição da velocidade}

Os conceitos da Economia que se referem ao aumento ou à diminuição nos gastos dos consumidores, provocando modificações na formação de novo capital (fator de aceleração ou coeficiente de aceleração), também podem ser interpretados como projeções oriundas da Física, porquanto, nessa área de conhecimento, a aceleração é um vetor que indica grandeza, direção e sentido - em outras palavras, a aceleração é uma variação da velocidade de um móvel sujeito à ação de forças externas (MACEDO, 1981, p. 3). Nesse sentido, compreende-se que a ECONOMIA É MOVIMENTO submetida a influências externas que podem "aumentar" ou "diminuir" a sua "velocidade" no que se refere ao mapeamento metafórico projetado para essa área de conhecimento.

O tipo de compreensão acima descrito é capaz de gerar termos como "Programa de Aceleração de Crescimento (PAC)", termo empregado, por exemplo, no governo Lula em 2007, que consistia em expressar um conjunto de políticas econômicas cujo objetivo durante os quatro anos seguintes de seu governo era o de aumentar o ritmo do crescimento econômico brasileiro. A metáfora da "aceleração" também denominou a unidade terminológica desaceleração econômica, processo pelo qual ocorre a "diminuição" da oferta de emprego, da produção e da demanda por produtos nacionais (ALVES, 2001a, p. 87).

Esse tipo de conceituação é o sétimo mais produtivo de nosso corpus de estudo. Ela ocorre em mais de doze termos metafóricos, correspondendo a 1,3\% do total de metáforas. Do ponto de vista linguístico, os termos formados a partir do conceito de "aceleração" apresentam-se normalmente sob a forma de uma lexia complexa (formação sintagmática), tais como aceleração da inflação, desaceleração econômica e Programa de Aceleração de Crescimento (PAC), entre outros. A seguir, apresentamos a contextualização de uma dessas unidades terminológicas: 
Na Alemanha, ao contrário, a existência de uma histórica ligação entre os grandes bancos e as grandes empresas industriais tem garantido a estas um volume de financiamento que dependeria menos do grau de publicidade dos dados financeiros, assim como das taxas de retorno correntes. A presença deste patient capital, como se referem Streeck (1996), Hollingsworth (1997), Hollingsworth e Boyer (1997) e Hall e Soskice (2001), faz com que as firmas possam manter seus trabalhadores qualificados em momentos de <desaceleração econômica> ou mesmo durante uma recessão moderada, e sejam capazes de se engajarem em projetos de investimento, cuja taxa de retorno seja atrativa apenas no longo prazo. (AMITRANO, C. R. Instituições $e$ desenvolvimento: críticas e alternativas à abordagem de variedades de capitalismo, 2010)

\section{h) temperatura}

Em relação ao oitavo conceito mais produtivo, destacam-se as unidades metafóricas compreendidas em termos de "temperatura". A projeção expressa no domínio-fonte ECONOMIA É TEMPERATURA ocorre em pelo menos quatro unidades terminológicas de nosso corpus de estudo, correspondendo a $0,4 \%$ do total de metáforas. Ainda que para os teóricos cognitivistas as metáforas relacionadas à "temperatura" sejam apresentadas como metonímias fisiológicas (KÖVECSES e RADDEN, 1998; RADDEN e KÖVECSES, 1999; PANTHER e RADDEN, 1999; RUIZ de MENDOZA, 1999; BARCELONA, 2000; DIRVEN e PÖRINGS, 2000; e PANHTER e THORNBURG, 2002, apud SILVA, 2003, p. 43), ${ }^{66}$ que se realizam quando uma determinada sensação física é ativada em relação a sensações como aumento ou baixa da temperatura do corpo, agitação física etc., resolvemos apresentar esse tipo de conceito como metafórico, uma vez que parece existir, em alguns momentos, um continuum entre a metáfora e a metonímia.

Para os cognitivistas, metáfora e metonímia não são mecanismos conceptuais independentes, e, de fato, esses recursos interagem frequentemente. Sendo assim, muitas vezes não há muita clareza dos limites entre um e outro processo, em virtude da interação que ocorre frequentemente entre a metáfora e a metonímia (SILVA, 2003, p. 51-2). Esse

\footnotetext{
${ }^{66}$ KÖVECSES, Z.; RADDEN, G. Metonymy: Developing a Cognitive View. Cognitive Linguistics, v. 01, p. 37-77, 1998; RADDEN, G.; KÖVECSS, Z. Towards a theory of metonymy. In: PANTHER, K-U.; RADDEN, G. (eds.). Metonymy in Language and Thought. Amsterdam: John Benjamins, 1999, p. 17-25; PANTHER, K-U.; RADDEN, G. (eds.). Metonymy in Language and Thought. Amsterdam: John Benjamins, 1999; RUIZ DE MENDOZA, F. J. Introducción a la teoría cognitiva de la metonimia. Granada: Método Ediciones, 1999; BARCELONA, A. "On the plausibility of claiming a metonymic motivation for conceptual metaphor". In: BARCELONA, A. (ed.). Metaphor and Metonymy at the Crossroads. Berlin: Mouton de Gruyter, 2000, p. 31-58; DIRVEN, R.; PÖRINGS, R. (eds.). Metaphor and Metonymy in Comparison and Contrast. Berlin: Mouton de Gruyter, 2002; PHANTER, K-U.; THORNBURG, L. (eds.). Metonymy and Pragmatic Inferencing. Amsterdam: John Benjamins, 2003.
} 
tipo de interação é evidenciada ora como "metonímia dentro da metáfora", ora, mais raramente, como "metáfora dentro da metonímia", ocorrendo também casos de "cumulação", ora como metáfora a partir de uma metonímia, ora, com menor frequência, metonímia a partir de uma metáfora (GOOSENS, 1990, 2002, apud Silva 2003, p. 52). ${ }^{67}$

Em relação ao corpus de estudo deste trabalho, encontramos o uso de unidades cujos conceitos são compreendidos como forma de "temperatura" para tratar do desenvolvimento positivo das atividades econômicas, constituindo casos em que podemos sentir o processo semântico ora como metonímico (causa e efeito), ora como metafórico (transferência de domínio).

As unidades terminológicas aquecimento econômico ou desaquecimento da economia são um tipo de caso que podemos categorizá-las como uma metáfora, pois aquecimento atribui um conceito positivo à Economia, ao passo que desaquecimento atribui um valor negativo. ${ }^{68}$

Interpretamos esses mapeamentos metafóricos como projeções do domínio-fonte da Física, pois "temperatura" refere-se a uma grandeza que caracteriza o equilíbrio térmico de um sistema com outro; havendo equilíbrio, a temperatura é constante em todos os pontos do sistema de forma que possa ocorrer passagem de calor. Em Economia, o que é mapeado metaforicamente a partir desse domínio-fonte são os aspectos semânticos relacionados a "calor", "aquecimento" ou, ao contrário disso, "desaquecimento" ou mesmo "congelamento". No caso do uso de congelamento no comércio internacional, esse fenômeno acontece quando, em geral, há uma insuficiência de divisas - circunstância que se aplica a uma situação em que uma dívida não saldada não pode ser cobrada do devedor nem recebida pelo credor durante um certo período (HOUAISS, 2001, p. 799). A seguir, apresentamos um desses termos comentados acima, extraído de nosso corpus de estudo:

Dois anos depois, os executores do Plano Verão (1989) procederam do mesmo modo, buscando conter a inflação através do controle do déficit público, com o agravante de promover os primeiros movimentos de privatização de diversas estatais, assumindo e promovendo a falência do Estado e explicitando a

\footnotetext{
${ }^{67}$ GOOSENS, L. Metaphonymy. The interaction of metaphor and metonymy in expressions for linguistic action. Cognitive Linguistics, v. 1-3, p. 323-40, 1990;___. Metaphtonymy. The Interaction of Metaphor and Metonymy in Expressions for Linguistic Action. In: DIRVEN, R.; PÖRINGS, R. (eds.). Metaphor and Metonymy in Comparison and Contrast. Berlin: Mouton de Gruyter, 2002, p. 349-77.

${ }^{68}$ Seguindo os pressupostos teóricos da Linguística Cognitiva, também é possível classificar esses termos como uma metonímia, porquanto podemos supor que a unidade aquecimento foi ativada a partir de determinado efeito fisiológico do corpo humano para falar do aumento das atividades econômicas.
} 
possibilidade iminente de hiperinflação. Posta essa sucessão de fracassos, não surpreende que a pretensa reforma monetária e o <congelamento> do Plano Collor (1990) tenham sido acompanhados tão rapidamente por uma fúria remarcatória: havia uma data estipulada para o fim do congelamento e a aceleração prévia da inflação não tinha precedentes (CARNEIRO, 2002). O novo congelamento do Plano Collor foi acompanhado de um regime de câmbio flutuante, e apesar de nova moratória, com a suspensão temporária do pagamento de juros do serviço da dívida externa, esse novo regime cambial viu uma substancial desvalorização real do câmbio comercial. Ocorreram pressões generalizadas de custo derivadas do movimento do câmbio e dos preços agrícolas, acentuando as pressões remarcatórias. (NOZAKI, W. V. Crise monetária e ciclo inflacionário no Brasil: as décadas de 1980 e 1990, 2010)

\title{
i) entropia
}

Em Economia, entropia significa tendência à perda, à desintegração e à desorganização (SANDRONI, 2005, p. 228). A origem desse termo é também da Física, pois nessa ciência tal fenômeno compreende a medida do grau de desordem de um sistema. Daí a analogia entre Física e Economia no que se refere ao traço semântico da “desorganização". Esse termo, cujo conceito (ou subconceito) pode ser compreendido por ECONOMIA É ENTROPIA nas unidades metafóricas do tipo entropia ou Lei da Entropia, não é muito frequente neste corpus analisado, apresentando somente dois termos $(0,2 \%$ do total $)$. A seguir, destacamos uma de suas realizações:

\begin{abstract}
Conforme mostram, entre outros, Faber et al. (1998), o conceito de <entropia> é peça fundamental na formulação da estrutura conceitual da economia ecológica. A contribuição de Georgescu-Roegen permitiu ressaltar a essência entrópica do funcionamento da economia, abrindo caminho para análises construídas sobre base mais realista das inter-relações entre o sistema econômico e o meio ambiente, centrais para avaliações bem fundadas da sustentabilidade do desenvolvimento. (MUELLER, C. C. O Debate dos economistas sobre a sustentabilidade - Uma avaliação sob a ótica da análise do processo produtivo de Georgescu-Roegen, 2005)
\end{abstract}

\section{j) luminosidade}

Em Física, luminosidade significa uma radiação eletromagnética que provoca a excitação do órgão da vista de um observador normal (MACEDO, 1981, p. 216). Um dos termos de nosso corpus que se refere à luz é efeito-farol. O farol é um tipo de "aparelhagem" que produz um foco luminoso. É compreendido metaforicamente como aquilo que encaminha, dirige ou lidera. No exemplo do termo que aparece em Economia como efeito-farol, estamos diante de um fenômeno que consiste no poder de balizamento 
que o salário mínimo tem sobre o mercado informal. O traço semântico que é mapeado nessa terminologia refere-se a algo que chama a atenção, no caso, à demarcação do salário mínimo em relação à renda criada pelo mercado informal, conforme o exemplo demonstrado a seguir:

\begin{abstract}
Há três canais de propagação da política de aumentos no SM. O primeiro é de natureza compulsória, uma vez que no mercado formal o empregador é obrigado a seguir parâmetros determinados legalmente. O segundo é o caráter de indexador da variável. O SM funciona como piso para outras fontes de rendimentos, que não aquelas recebidas no mercado de trabalho. Esse é o caso do seguro-desemprego e do piso previdenciário e assistencial. O terceiro canal refere-se ao <'efeito farol'>, termo criado por Souza \& Baltar (1982), apud Neri et al. (2001). Este efeito consiste no poder de balizamento que o SM legalmente determinado tem sobre o mercado informal, que a priori estaria fora de sua abrangência. (AFONSO, L. E.; PEREDA, P. C.; GIAMBIAGI, F.; FRANCO, S. O salário mínimo como combate à pobreza extrema: estariam esgotados seus efeitos?, 2011)
\end{abstract}

Os conceitos da Física que se referem a "luminosidade" geraram no corpus analisado dois tipos de unidades terminológicas: efeito-farol, já comentado por nós anteriormente, e preço-sombra, termo decalcado do inglês shadow price, que significa em Economia um preço imputado a um produto ou serviço que não tem cotação no mercado. Esses preços representam o custo de produzir um produto que não é transacionado no mercado (SANDRONI, 2005, p. 769). Logo, o aspecto semântico explorado por esse tipo de metáfora em relação ao domínio-alvo é o que se refere àquilo que não é visível.

\title{
k) medida
}

Em ECONOMIA É MEDIDA, a “calibração” denomina em Física a operação em que se estabelece a correspondência entre uma grandeza física e a escala de um instrumento em que ela é medida de forma direta ou indireta (HOUAISS, 2001, p. 574). Interpretamos que o termo calibragem é proveniente da Física, porquanto ele se refere a um tipo de "ajuste" que é realizado por meio de aparelhos de calibração. Em Economia, o termo é usado para se referir a uma técnica em que simulações comparam o ajuste aos dados de um conjunto de intervalos de valores para determinados parâmetros, conforme atesta o contexto em que a unidade é empregada a seguir. Esse tipo de conceito ocupa o último lugar junto ao termo atrito, que será comentado a seguir. Dos conceitos 
representados pela Física, licencia-se apenas uma expressão linguística, ou seja, 0,1\% do total de termos em análise, conforme pode ser evidenciado em seu contexto:

\begin{abstract}
Atualmente existem outras estratégias de identificação e estimação dos parâmetros além de aquelas observadas por Sims (1980). Do modelo estrutural construído como um modelo de equilíbrio geral dinâmico e estocástico (DSGE, da sigla em inglês), no qual podem ser racionalizadas evidências empíricas observadas originalmente em estimativas com vetores autorregressivos, as estimativas podem ser obtidas sob a hipótese dos agentes conhecerem o modelo teórico [...]. Além de isso, podem ser empregadas as chamadas técnicas de <calibragem>, na qual simulações comparam o ajuste aos dados de um conjunto de intervalos de valores para determinados parâmetros. Por fim, pode se utilizar técnicas de modelagem de aprendizado como o método bayesiano, por exemplo. [...]. Johansen (2006) demonstra que mesmo métodos onde o modelo correto da economia é conhecido, podem levar a erros de inferência se a distribuição associada aos resíduos estocásticos não permite um ajuste adequado aos dados. (AGGIO, G. de O. Análise sistêmica para fenômenos monetários, 2011).
\end{abstract}

\title{
l) atrito
}

Esse domínio da Física refere-se a uma força de contato que atua sempre que dois corpos entram em choque (MACEDO, 1981, p. 4). É ocasionado pela "asperidade" dos corpos que entram em "atrito" (ato de friccionar). Em economia financeira, a "fricção" ocorre quando o mercado não funciona de maneira eficiente. Esse conceito de baixíssima produtividade $(0,1 \%)$ é responsável pela projeção da expressão linguística fricção financeira. A seguir, um excerto de um dos textos coletados em nosso corpus em que esse termo ocorre:

\begin{abstract}
Através desse trabalho foi possível comparar o modelo estimado com um modelo sem nenhum tipo de <fricção financeira> através de respostas ao impulso de ambas as economias. Fazendo essa análise notamos que as fricções financeiras por um lado tendem a diminuir as respostas do produto e do consumo da economia como um todo, e juntamente reduzir os lucros bancários, mas por outro lado os custos de ajustamento do setor bancário ajudam na contenção do nível de preços da economia brasileira. (ARANHA, M. Z. Um modelo dsge com friç̧ões financeiras aplicado ao Brasil, 2012.)
\end{abstract}

Por último, apresentaremos um gráfico com a distribuição das metáforas da Física de acordo com os dados apresentados pela Tabela 1 abaixo, cujo objetivo é o de facilitar a visualização da posição ocupada por suas categorias conceptuais. Essa disposição gráfica nos permite concluir que as metáforas mais frequentes são, em primeiro lugar, as relacionadas à "instantaneidade", evidenciadas pelos termos metafóricos a exemplo de liquidez; em segundo lugar, "impacto" licenciando unidades como choque; em seguida, "dissipação" com unidades ilustradas por metáforas como volatilidade e bolha; em 
quarto, "equilíbrio" e suas lexicalizações como balanço; em quinto, "flexibilidade" com alguns exemplos em elasticidade; em sexto, "impulso" produzindo termos como alavancagem; em sétimo, "velocidade (variação)" e suas unidades do tipo aceleração; em oitavo, "temperatura" licenciada por aquecimento; e, nas últimas posições, "entropia", “desintegração", "medida" e "atrito".

\section{Gráfico 1 - Representação dos resultados da Tabela 1}

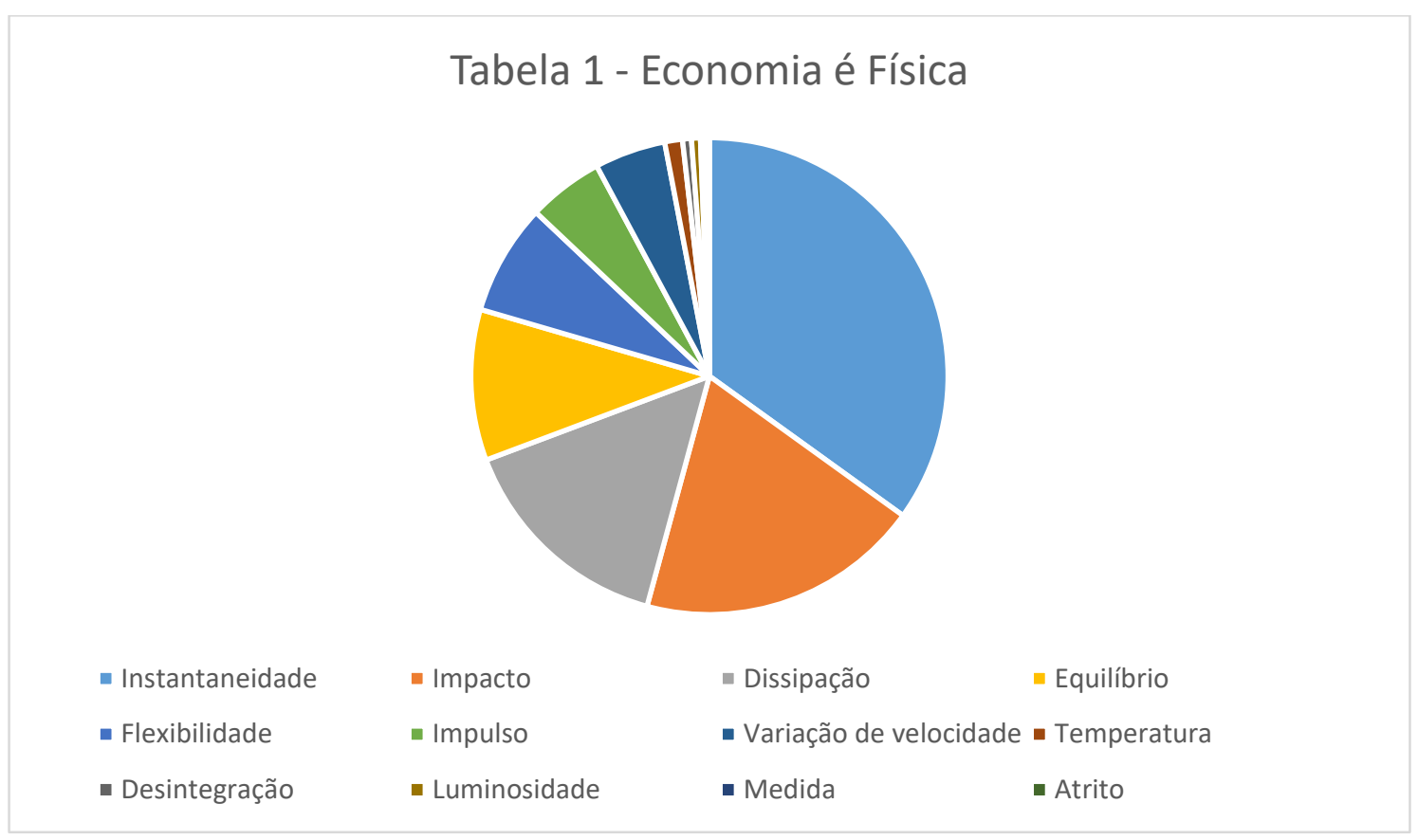

Esses dados nos levam a concluir que as principais metáforas em Economia cujos domínios-fontes são oriundos da Física perfazem conceitos relacionados à "liquidez", visto que todos os investimentos econômicos que podem ser resgatados "instantaneamente" são positivos. As projeções que fazem referência a "choques" também são bastante frequentes, referindo-se a medidas adotadas de forma "impactante" para que os processos econômicos reajam de forma positiva nas sociedades em que atuam. A "volatilidade" demonstra preços oscilantes; "bolhas" traduzem a imagem de alguns investimentos que "inflam" de forma desregrada, dissipando-se mais à frente de forma análoga a uma bolha de sabão.

Sujeita a tantas intempéries, a Economia procura um ponto de "equilíbrio" e, por isso, produz termos criados a partir da metáfora "balanço". Seu funcionamento também é "elástico", revelando a variação de bens de demanda cuja elevação do preço acarreta imediata diminuição da demanda. Para que alguns investimentos sejam lucrativos sem 
que o investidor faça muito esforço, surgem as metáforas em torno da "alavancagem". Uma Economia também pode variar o ritmo de sua "velocidade", normalmente, pensa-se nela em um ritmo "acelerado", pois isso implica, nas culturas capitalistas, nas quais ela deve variar a sua "aceleração" de forma rápida, e não lenta. Esse mesmo conceito pode se traduzir em "temperatura": uma economia "aquecida" é algo "positivo".

\section{$\underline{\text { As metáforas da Biologia apresentadas na Tabela } 2}$}

Os mapeamentos cognitivos metafóricos da Economia cujos domínio-fontes são oriundos da Biologia são bastante representativos também neste corpus científico, de forma que o domínio ECONOMIA É BIOLOGIA licencia em torno de 300 unidades terminológicas metafóricas nos corpora coletados. A seguir, apresentaremos a análise desses "subconceitos" ou "conceitos", de acordo com a sua ordem de frequência:

\section{a) fluxo}

Julgamos que esse domínio deveria aparecer no domínio-fonte da Biologia, porquanto a metáfora do "fluxo" tem origem nos campos da Medicina e das Ciências Biológicas, mapeando o conceito de que ECONOMIA É MEDICINA.

A fim de demonstrar como um modelo econômico poderia ser equilibrado, o médico e economista francês François Quesnay criou um organograma conhecido por Tableau économique para ilustrar os processos de produção, circulação de moeda e de distribuição de renda: "descreve assim o recebimento das rendas as transações e alocações dos produtos agrícolas e industriais, assim como a perfeita alocação de moedas para essas transições, que deve ter circulação contínua" (AJZENTAL, 2015, p. 140).

Esse conceito foi apropriado por Quesnay para mapear o esquema imagético de circulação do equilíbrio econômico, cujos elementos são análogos à distribuição do sangue através do coração e dos vasos sanguíneos. Como Quesnay era um médico que se tornou líder do movimento fisiocrata francês no século XVIII, acredita-se que tenha criado esse modelo a partir de sua experiência como médico.

O conceito de fluxo também pode ser interpretado como algo positivo para a Economia, pois, em nossa cultura, conforme já comentamos anteriormente, tudo o que “flui" é bom e o que é estagnado é "ruim". Assim, além da projeção metafórica ECONOMIA É SANGUE QUE FLUI, podemos compreendê-la também em termos de 
ECONOMIA É CORRENTE DE ÁGUA, revelando também outro tipo de conhecimento da experiência humana por meio da observação da correnteza de água.

Essa conceituação é a mais produtiva em relação aos termos estudados nesse tipo de domínio, sendo responsável pela lexicalização de mais de 117 termos a partir de fluxo, correspondendo a 14\% das unidades metafóricas desta análise. A seguir, um dos exemplos citados na tabela de domínios: fluxo, fluxo de caixa, fluxo de caixa livre, entre outros.

Exceto para firmas com projetos de investimentos não rentáveis, a teoria do <fluxo de caixa livre> supõe que os preços das ações sobem com aumentos inesperados de pagamentos aos acionistas (ou promessa de aumentos) e caem com a redução de pagamentos ou nova requisição de fundos (ou perspectiva de reduções de pagamentos futuros). (JESUS JR., L. B. de. Petrobras, intervenção governamental e maximização do valor para o acionista: uma sugestão de interpretação, 2015.)

\section{b) doença e saúde}

Como a Economia é compreendida analogicamente pelos conceitos projetados do domínio-fonte para o domínio-alvo referentes à Biologia, mais propriamente no que se refere ao "organismo" e ao "corpo" humanos, é natural que esse "corpo" físico possa ser saudável ou também adoecer. Para a compreensão do que vem a ser uma Economia que não funciona satisfatoriamente, usam-se normalmente no corpus coletado metáforas relacionadas à doença. Alves (2016) e Silva (2013) analisam algumas dessas analogias em seus trabalhos. Alves (2016, p. 49) afirma que a Economia estabelece um diálogo constante com a Medicina. Essas duas ciências se entrelaçam, porquanto, são muito presentes na vida dos cidadãos.

Para Silva (2013, p. 293), as metáforas do corpo do ponto de vista da saúde e da doença servem não somente para conceptualizar o funcionamento e a complexidade dos sistemas financeiros e econômicos, mas também sua vulnerabilidade, com mapeamentos cognitivos oriundos da doença. Em momentos em que a Economia não é satisfatória, as metáforas revelam a compreensão de que ECONOMIA É DOENÇA. Essa conceituação é a segunda mais produtiva dos termos estudados, licenciando 110 unidades, correspondentes a $13 \%$ dos termos. O conceito mais frequente é o relacionado à "crise", seguido de "colapso". Somente para "crise" foram localizados 85 termos. A etimologia dessa palavra aponta para a situação em que existe um momento decisivo da doença (ALVES, 2016, p. 54), ou seja, quando esse conceito da ECONOMIA É CRISE é 
licenciado por unidades lexicais do tipo crise econômica, isso significa que está havendo um desequilíbrio entre produção e consumo.

Uma Economia “doente" pode então entrar em "crise" e até "colapsar", logo, a designação de termos como crise econômica, crise financeira, crise cambial, crise de liquidez, crise bancária e crise da dívida externa, entre tantas outras. No concordanciador da linguagem Pyton usado para o tratamento deste corpus, foram encontrados 604 registros de termos relacionados a "crise". Quando o conceito de crise ultrapassa seus limites de "piora", surgem os termos colapso do mercado de hipotecas, colapso financeiro, colapso do Fordismo, ou simplesmente, colapso.

Do ponto de vista de doenças psicológicas, encontramos metáforas em nosso corpus de estudo representadas por "pânico" ou mesmo "estresse". No estudo comparativo de metáforas extraídas de relatórios financeiros entre o inglês e o espanhol realizado por Charteris-Black e Ennis (2001, p. 5), os autores afirmam que há muitas metáforas de motivação psicológica. Observamos que essas metáforas apresentam também um forte apelo "emocional", em que uma situação de desespero e de dor está instaurada. A seguir, o termo pânico financeiro, que demonstra esse tipo conceituação da Economia:

\begin{abstract}
Ademais, a intermediação dos fluxos de capitais pelos bancos resulta inevitavelmente num boom nos preços dos ativos de oferta inelástica, o qual seria seguido por um crash na ocorrência de um <pânico financeiro> (na medida em que os bancos teriam que liquidar esses ativos para fazer frente aos resgates dos depositantes ou à fuga dos credores externos), agravando os efeitos deletérios da crise bancária. (PRATES, D. M. A literatura convencional sobre as crises financeiras nos países "emergentes": os modelos desenvolvidos nos anos 90, 2005)
\end{abstract}

A fim de "curar" todas essas "doenças", são licenciadas metáforas a partir do conceito ECONOMIA É SAÚDE, tais como saneamento financeiro, drenagem de recursos financeiros e injeção de liquidez ou injeção de crédito. Observa-se que esses dois últimos termos são empregados para estabelecer, por exemplo, o sentido da geração de emprego e de renda. "Pacotes" também são "tônicos" para a "cura" da crise econômica. Com uma frequência baixa (seis termos, representando $0,6 \%$ dos termos), se comparadas com o domínio ECONOMIA É DOENÇA, poucas unidades metafóricas são geradas a partir desse conceito, o que nos leva a inferir que a Economia encontra-se normalmente mais "doente" do que "saudável" (em outras palavras, em situações mais desfavoráveis 
do que favoráveis). Para ilustrar essa dimensão cognitiva, escolhemos um dos excertos de textos dos corpora científicos em que os termos foram prospectados:

\begin{abstract}
Por outro lado, há que se avaliar, também, a pertinência de se alterar as atuais regras de gestão financeira do FAT, desde que tais alterações não comprometam constitucionais. Por alguns anos, os recursos do FAT, na forma dos programas de geração de emprego e renda, supriram a escassez de crédito de diferentes setores econômicos, representando expressiva <injeção de crédito> na economia. Assim, reconhece-se que é importante estudar se a reorientação dos programas de geração de emprego e renda e, consequentemente, a extinção de algumas linhas, provocariam gargalos à produção nacional, ou se essa demanda de crédito poderia ser suprida pelos bancos de desenvolvimento, agências de fomento e bancos comerciais. (CARDOSO JR., J. C. P. Mundo do trabalho e (des)proteção social no Brasil: ensaios de interpretação da história recente, 2013)
\end{abstract}

Para Silva (2013, p. 310), além da sua função explicativa e emotiva, as metáforas da doença e da catástrofe natural desempenham uma importante função ideológica, servindo para atribuir a culpa a causas externas e incontroláveis, ocultando as verdadeiras origens dos problemas econômicos e financeiros, dissimulando dessa forma as responsabilidades dos agentes econômicos e políticos que atuam de forma perversa no cenário econômico e financeiro de mercado livre: "A natureza automática e inconsciente destas metáforas leva a que a opinião pública nem sequer se dê conta de que está a organizar o seu pensamento com base em ideias criadas por outros" (SILVA, 2013, p. $310)$.

\title{
c) organismo
}

Ocupando a terceira posição em produtividade, o subconceito de "organismo" oriundo do conceito biologia designa 49 termos, correspondentes a $6 \%$ das metáforas estudadas neste trabalho. Esse domínio ECONOMIA É ORGANISMO também é bastante representativo, chancelando uma série de mapeamentos e compreensões da área econômica. Em Biologia, o termo organismo designa um conjunto de órgãos que constituem um ser vivo (planta ou animal). Com uma frequência de 49 termos, encontramos a metáfora do "crescimento". Nesse sentido, os sistemas financeiro e econômico são compreendidos como entidades orgânicas que podem crescer, contrair, metabolizar, ter raízes, amadurecer e decompor-se. A seguir, uma dessas metáforas contextualizadas em que a Economia é concebida em termos de "crescimento". 


\begin{abstract}
A partir do início da década de 1970, o Prêmio Nobel Robert Solow, um expoente da análise econômica convencional, com importantes contribuições à teoria do capital, do <crescimento econômico> e, mais recentemente, dos recursos naturais, vem discutindo o conceito de sustentabilidade do ponto de vista da análise econômica. (MUELLER, C. C. O debate dos economistas sobre a sustentabilidade - uma avaliação sob a ótica de análise do processo produtivo de Georgescu-Roegen, 2005)
\end{abstract}

O crescimento econômico significa o aumento da sua capacidade produtiva, consequentemente da produção de bens e de serviços de determinado país ou área econômica. Para Berber Sardinha (2007, p. 110), a metáfora do "organismo" no mundo globalizado assume um papel principal na atualidade, uma vez que instituições empresariais relacionam-se entre si e vivem em conjunto com outras empresas, em uma espécie de ecossistema, conceituando-a como ECONOMIA É ECOLOGIA. ${ }^{69}$

Se a Economia é compreendida em termos de "organismo", podemos afirmar que ela é um “corpo". Comentários sobre esse domínio serão feitos a seguir.

\title{
d) corpo
}

Responsável por $1 \%$ dos termos metafóricos, gerando nove unidades metafóricas prospectadas neste corpus, encontramos o quarto conceito mais produtivo, que é ECONOMIA É CORPO. Essas metáforas, cujos domínios se originam do corpo humano, são visíveis em expressões linguísticas que compreendem a Economia em termos de "saúde" ou "doença". Já estudadas por Ullmann (1964, p. 442), não do ponto de vista cognitivo, mas da imaginação e da expressividade, essas metáforas antropomórficas originam-se a partir da relação do homem com o seu próprio corpo.

Para falar sobre o sistema financeiro e econômico, lexicalizam-se, por exemplo, termos metafóricos como capital humano. No sentido lakoviano, esse termo pode ser categorizado como metáfora ontológica, uma vez que "capital” é personificado para que possamos nos referir a ele, identificá-lo, agir em relação a ele, e o compreendermos, como uma força de trabalho, ou um tipo de investimento financeiro em força humana a partir de uma metáfora. A seguir, um de seus contextos extraído dos textos científicos captados para esta pesquisa:

\footnotetext{
${ }^{69}$ Esse conceito licencia a unidade linguística valor ecológico, compreendendo o valor de um serviço "sustentável", mas cujo valor econômico é difícil de calcular.
} 
$\mathrm{O}<$ capital humano>, que envolve a capacitação e as habilidades para produzir da força de trabalho da sociedade em um dado momento. Para aumentar o seu <capital humano> a sociedade investe em educação, em treinamento, em capacitação. Este componente tem recebido atenção especial recentemente. (MUELLER, C. C. O debate dos economistas sobre a sustentabilidade - uma avaliação sob a ótica de análise do processo produtivo de Georgescu-Roegen, 2005)

Outra metáfora desse tipo, já bastante conhecida pelos economistas desde o século XVIII a partir da publicação da obra $A$ riqueza das nações, de Adam Smith, e cujo domínio-fonte é mapeado pelo conceito de "corpo", é a da mão invisível. Segundo Sandroni (2005, p. 511), esse termo significa uma coordenação "invisível" capaz de assegurar a consistência dos planos individuais numa sociedade em que predomina um sistema de mercado, ou seja, o mercado livre autorregula-se sem a necessidade de intervenção do Estado. Se a ECONOMIA É CORPO, mão invisível apresenta-se como uma dimensão metonímica dessa metáfora, uma vez que "mão" é uma parte do "corpo humano"; porém, como sabemos que não se trata de uma mão no sentido literal, consideramos o termo mão invisível como uma metáfora, pois o que está sendo mapeado aqui é o sentido de que a "mão" é "ajuda", "auxílio", oriundos de forças econômicas que não são visíveis (o que regularia o mercado, portanto, não são as intervenções do Estado, mas sim, aquelas que não são perceptíveis, como as leis de oferta e de procura). A seguir, o termo contextualizado:

\begin{abstract}
Com estas inovações, os modernos diretores de empresas completaram os instrumentos essenciais pelos quais a mão visível da direção pode substituir a <mão invisível> das forças de mercado na coordenação e controle das atividades econômicas. Ao mesmo tempo em que aperfeiçoaram os procedimentos para a administração dos processos de produção e distribuição correntes, os diretores da Du Pont idealizaram e melhoraram aqueles requeridos para destinar os recursos para a produção e distribuição futuras. (VASCONCELOS, L. A. T. Processo de gestão estratégica nas empresas: proposta de metodologia para análise determinantes dos movimentos e dos graus de autonomia das unidades produtoras, 2011)
\end{abstract}

\title{
e) ecologia
}

Esse conceito licencia a unidade linguística valor ecológico, representando o custo de um serviço "sustentável”, cujo valor econômico é difícil de ser calculado. O domínio projetado nessa conceituação equivale a ECONOMIA É ECOLOGIA, algo que não pode ser mensurado devido à sua amplitude ecológica. 
Portanto, o valor da dimensão econômica não pode ser considerado isoladamente dos valores das duas outras dimensões no processo de decisão. Há uma correlação entre o <valor ecológico> (sustentabilidade) e valor econômico, uma vez que um ecossistema muito importante para a sustentabilidade provavelmente também possui funções ecossistêmicas que geram importantes serviços ecossistêmicos. (ROMEIRO, A. R. Economia ecológica e valoração da natureza, 2013)

$\mathrm{Na}$ Tabela 2 abaixo, é apresentada a distribuição das metáforas da Biologia, de forma que a escala de cada um dos subconceitos, que fazem parte desse domínio, nos leva a constatar que as metáforas mais frequentes são, em primeiro lugar, relacionadas à “corrente sanguínea ou de água”, evidenciadas pelas metáforas do tipo fluxo; em segundo lugar, "doença", licenciando unidades como crise; em terceiro, "organismos", exemplificadas por termos como crescimento; em quarto, "corpo humano" e suas lexicalizações em mão invisível; e, em último lugar, "ecologia", a exemplo de valor ecológico.

\section{Gráfico 2 - Representação dos resultados da Tabela 2}

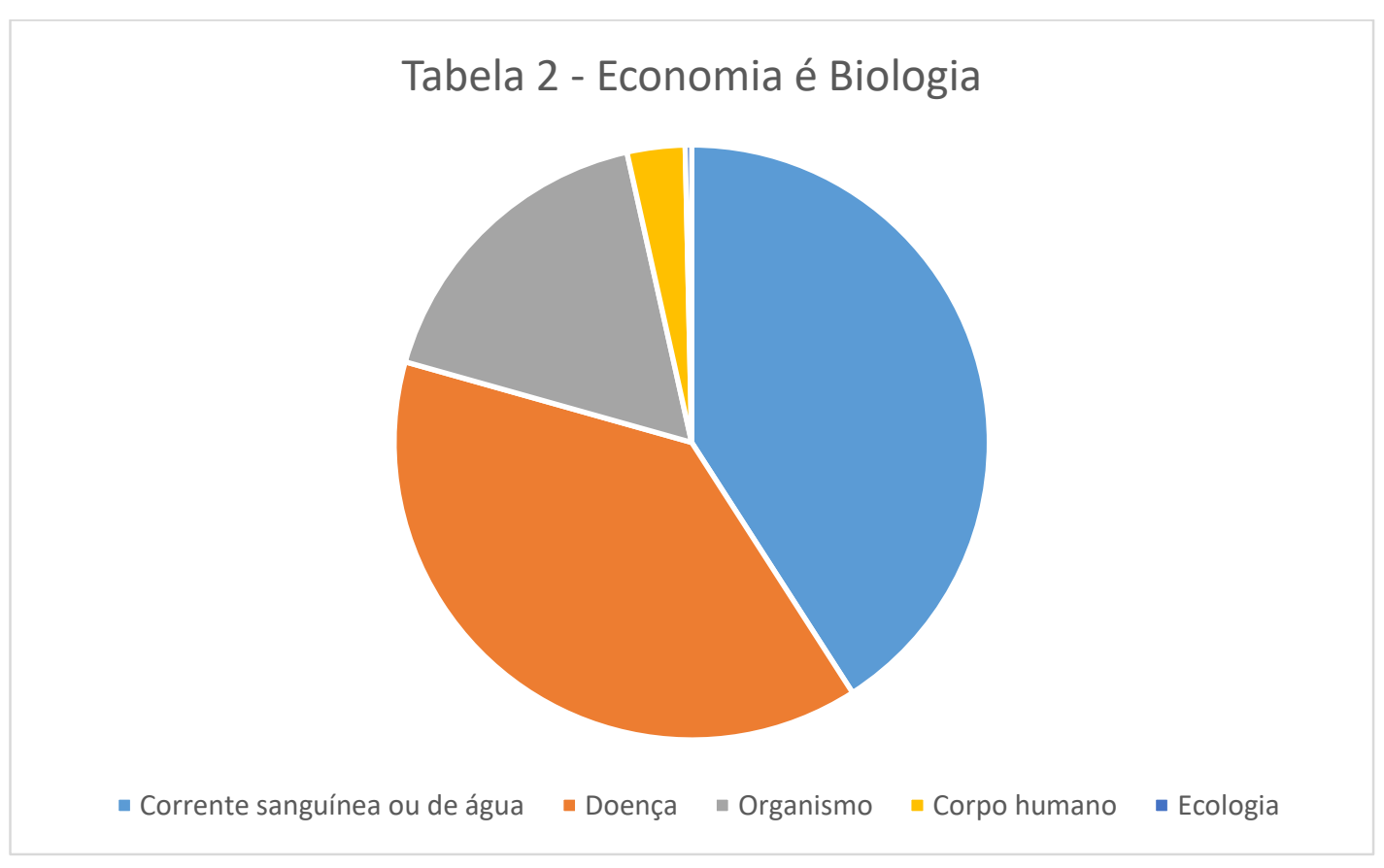

Essas informações nos permitem depreender que as principais metáforas em Economia, cujos domínios-fontes são oriundos da Biologia, concentram-se em torno de conceitos relacionados a "corrente sanguínea ou de água", porquanto os processos econômicos que fluem são positivos. Bastante produtivos também são os domínios relativos a "doença" e a "organismo", visto que Economias são compreendidas como seres que podem adoecer - havendo maior quantidade de termos relacionados a doença e 
menor parcela de unidades relativas a saúde, permitindo-nos inferir, mais uma vez que, a Economia se encontra normalmente em um estado mais débil do que saudável. Por último, identificamos somente uma metáfora com referência a "ecologia", evidenciada por valor ecológico. Essa baixíssima frequência possivelmente ocorre, conforme comentamos anteriormente, porque seu preço não é incorporado nas análises econômicas.

\section{$\underline{\text { As metáforas orientacionais apresentadas na Tabela } 3}$}

Nas tabelas anteriores, analisamos as metáforas estruturais e um caso de metáfora ontológica. As metáforas estruturais, como pudemos demonstrar, são altamente recorrentes neste corpus estudado e referem-se aos domínios em que um conceito é estruturado metaforicamente em termos de outro. A representação metafórica dos conceitos que estruturam nossas atividades cotidianas pode aparecer em circunstâncias nas quais compreendemos a ECONOMIA em termos de DOENÇA, por exemplo. Nesta Tabela 3, nosso objetivo é buscar também estudar as metáforas orientacionais pelo fato de elas se fazerem presentes em 117 projeções, correspondentes a $13 \%$ das unidades totais (860) desta espécie de estudo.

Conforme comentamos anteriormente, compreendemos o mundo por meio de metáforas construídas com base em nossa experiência corporal. Nossa corporeidade e nossa mente interagem para dar sentido ao mundo. A maior parte dessas metáforas tem a ver com a orientação espacial do tipo para cima/para baixo, dentro/fora, frente/trás, em cima de/fora de (on-off), fundo/raso, central/periférico (LAKOFF; JOHNSON, 2002, [1980], p. 59).

Seguindo essa tipologia, propomos, a seguir, alguns exemplos de metáforas orientacionais encontradas neste corpus investigado:

\section{a) fundo/raso}

Para a orientação espacial "fundo-raso", não identificamos termos metafóricos da categoria "raso"; porém, para a noção de "fundo", localizamos 103 unidades terminológicas, ou seja, $12 \%$ do total de metáforas (860). A projeção desse conceito

"fundo" é extremamente produtiva em Economia, principalmente quando se refere a uma 
forma de aplicação financeira: "fundo de ações", "fundos de investimento", "fundos de curto prazo" etc.

De acordo com pesquisa eletrônica realizada no Dicionário Merriam-Webster online,$^{70}$ o vocábulo fundo origina-se do latim e estabeleceu-se na língua inglesa no século XVII. A etimologia dessa palavra tem uma base francesa no termo fond significando "fundo", bem como "estoque de capital" ou "pedaço de propriedade fundiária". De sua raiz latina, apresenta-se o sentido da noção espacial de "fundo" ou então "pedaço de propriedade fundiária". Aparentemente, a palavra fundo, mesmo tendo a sua origem no latim, é introduzida pelos ingleses via influência francesa. Inicialmente, fundo era usado apenas com valor literal e também figurado, a exemplo de "fundo da alma". Tomando o sentido emprestado via língua francesa, a palavra foi usada com o valor de suprimento ou estoque de coisas materiais e imateriais. No final do século XVII, a palavra fundo começou a ser empregada para denominar uma certa quantidade de dinheiro para o exercício de um negócio ou empresa para apoio e manutenção institucional ou individual.

As informações etimológicas apresentadas acima nos levam a inferir que o sentido de fundo, com o significado de investimento, ainda que tenha vindo do francês, é primariamente de origem latina, projetando a perspectiva espacial de "fundo", que é o contrário de "raso". Do ponto de vista conceitual, esse tipo de domínio é positivo, uma vez que fundo é um tipo de "dinheiro" que serve como investimento.

A metáfora fundo é tão frequente na Economia que parece se esvaziar de sua carga metafórica, podendo ser considerada, por alguns, como uma metáfora morta. Conforme já fora apontado em nossa dissertação de mestrado (COSTA, 2007) e no trabalho de Alves (2001, p. 178-9), ao se referirem às metáforas vivas (em que se explora a analogia entre domínios conceptuais diferentes) e às metáforas mortas (em que o conceito novo está estabilizado e sua ativação já não mais implica a exploração desse processo de analogia), assegura-se que as metáforas da Economia são, inicialmente, metáforas vivas; porém, com o passar do tempo, quando mais são empregadas por economistas, mais elas vão se tornando metáforas mortas no interior desse grupo, mesmo podendo permanecer como metáforas vivas para outros interlocutores. ${ }^{71}$

70 Dicionário Merriam-Webster: disponível em <https://www.merriam-webster.com/words-atplay/financial-word-origins/capital>. Acesso em: 10 jul. 2019.

${ }^{71} \mathrm{O}$ fato de que as metáforas usadas por especialistas tornam-se mortas com o passar do tempo pôde ser confirmado quando alguns economistas entrevistados por nós, tais como os professores-pesquisadores Alberto Ajzental e Ladislau Dowbor, declararam não compreender que esse termo tivesse motivação metafórica. 
Conforme mencionamos acima na análise de outros termos metafóricos, a metáfora fundo também pode se juntar a outras. É o caso, por exemplo, de fundo aberto. Em fundo, a orientação espacial é do tipo "fundo-raso" e, em "aberto", estamos diante da metáfora do receptáculo ou do contêiner. Nesses exemplos, somente um dos termos apresenta mais carga metafórica do que outro. Em fundo aberto, o segundo termo "aberto" (elemento determinante), "ilumina" o sentido dessa formação sintagmática. Nesse sentido, o fundo é "aberto" porque é um tipo de investimento administrado por instituições financeiras que realizam esse tipo de aplicação através de planos individuais, ao contrário de fundo fechado, que atua por meio de planos ligados a empresas.

A seguir, apresentamos esses termos de forma contextualizada:

\title{
- fundos abertos
}

\begin{abstract}
Outra comparação que faremos será entre os fundos restritos a investidores qualificados frente aos <fundos abertos> ao público geral. Nesse caso, queremos investigar se os gestores atuam de maneira diferente, dependendo da clientela para a qual seu FIA está voltado. Investidores qualificados têm, em princípio, uma maior capacidade de monitorar a atuação do gestor do que o público geral. Com uma maior capacidade de monitoramento, os investidores qualificados podem enxergar a prática de inflacionar os preços dos encerramentos de período como prejudicial aos seus interesses, fazendo com que o gestor do fundo não recorra a esse artifício quando sua clientela é formada por investidores qualificados. (SANEMATSU, F. C. Remuneração dos gestores, públicoalvo e conflitos de interesse em fundos de ações no Brasil, 2013)
\end{abstract}

\section{- fundos fechados}

Pinheiro (2004), por exemplo, vê riscos de ordem institucional, política e administrativa na natureza pública dos fundos fechados. Riscos institucionais porque se criará uma estrutura de supervisão e regulação ao nível da União para monitorar os < fundos fechados> instituídos pelos Estados, Municípios e Distrito Federal. Pelos princípios de autonomia federativa, esta estrutura pode enfrentar dificuldades para cumprir sua missão. (UEDA, D. M. Sistema previdenciário brasileiro: aspectos macroeconômicos e distributivos, 2005)

\section{b) alto/baixo}

As metáforas de espacialização que se referem a "alto" apresentam uma carga semântica de valor positivo. É o caso, por exemplo, de alta e de alta liquidez. Nesse último termo, alta aparece em função adjetival para especificar o tipo de liquidez, referindo-se a um processo econômico em que os lucros são obtidos rapidamente (por isso, alta). Contudo, o adjetivo "alta" é invertido, pois em vez de ele aparecer na posição 
de determinante, assume a posição de elemento determinado, reforçando dessa maneira o valor semântico de alta.

As metáforas que fazem projeções metafóricas do tipo "para baixo" determinam o valor negativo do termo, tais como: baixa ou baixa liquidez. O termo baixa, por exemplo, representa um índice desfavorável de encerramento na Bolsa de Valores. Baixa liquidez é o contrário de alta liquidez e essa denominação é empregada para a situação em que o investidor não consegue converter rapidamente seus investimentos em dinheiro. A mesma inversão morfológica que ocorre em alta vai acontecer em "baixa", dessa vez para significar um tipo de liquidez muito ruim, que demora para ser convertido. Logo, o que é "para baixo" em Economia é algo negativo.

Em relação ao total de metáforas deste corpus de estudos, esses conceitos metafóricos acima comentados representam o valor de $1,1 \%$, licenciadas por onze termos. A seguir, apresentamos esses termos em seus contextos reais de uso:

\title{
- alta liquidez
}

A teoria ortodoxa da firma bancária, tal como apresentada, por exemplo, nos escritos de Tobin (1998), considera que o problema decisório fundamental enfrentado pelo banco enquanto firma consiste na escolha entre um conjunto de ativos rentáveis e com baixa liquidez (empréstimos e investimentos) e um outro conjunto de ativos com baixa rentabilidade e <alta liquidez> (ativos defensivos). (OREIRO, J. L. Preferência pela liquidez, racionamento de crédito e concentração bancária: uma nova teoria pós-keynesiana da firma bancária, 2005)

\section{- baixa liquidez}

\begin{abstract}
A securitização de ativos foi um instrumento essencial para viabilizar a dinâmica de valorização patrimonial. Ao partir de um ativo único, inicialmente indivisível e, normalmente, de <baixa liquidez>, pode se reconfigurar a partir de estrutura jurídica específica e assumir nova condição. Uma vez fragmentado, torna-se acessível a uma quantidade substancialmente maior de investidores e objeto de múltiplas operações. CATÃO (2006) mostra que a securitização teve papel de catalisador no processo de desenvolvimento econômico nos Estados Unidos do início dos anos 1970, para garantir recursos ao sistema de financiamento imobiliário e atender à demanda da geração de baby boomers. (LOPES, G. N. Serviços de infraestrutura como opção de investimentos para os fundos de pensão brasileiros, 2012)
\end{abstract}

\section{c) central/periférico}

Em relação aos domínios espaciais de "central/periférico", encontramos somente um exemplo com "central”, evidenciado pela expressão linguística espiral inflacionária, 
uma vez que "espiral" se refere a um conceito espacial, podendo ser analisado como uma linha curva que faz um movimento para o centro. Em Economia, uma espiral inflacionária implica um processo em que elementos interligados, participantes da inflação, funcionam como geradores de mais inflação, em um processo autoalimentador - aumento contínuo nos custos, preços, salários, impostos etc., com a consequente desvalorização da moeda (SANDRONI, 2005, p. 312). Esses processos de interligação giratória são o elemento mapeado por essa metáfora, que pode ser compreendida em termos de mobilidade: o movimento da espiral é realizado em forma de círculo interpretado numa linha curva que se desenrola em um plano regular a partir de um ponto, dele afastando-se gradualmente (HOUAISS, 2001, p. 1233).

\begin{abstract}
Quanto à política salarial implementada pelo PAEG, o objetivo principal era combater a inflação de custos provocada pelos aumentos superiores à produtividade. Entendia-se que os reajustes salariais colocavam em movimento a chamada <espiral inflacionária>, de modo que era preciso "impedir que reajustamentos salariais desordenados realimentem irreversivelmente o processo inflacionário" (PAEG, 1964, p. 83). Nesse contexto, o princípio fundamental que deveria nortear a política salarial era que os salários reais só poderiam ser elevados pelo aumento da produtividade e aceleração do desenvolvimento, de modo que - no bojo do esforço de contenção do processo inflacionário - as medidas nesta área visavam eliminar a instabilidade dos salários reais sem, todavia, elevar a média dos mesmos (PAEG, 1964, p. 34). (BASTIAN, E. F. O PAEG e o Plano Trienal: Uma análise comparativa de suas políticas de estabilização de curto prazo, 2013)
\end{abstract}

\title{
d) verticalização/horizontalização
}

Consideramos também a verticalização como um conceito espacial, posto que essa metáfora se refere a um tipo de orientação que é "para cima". Em nosso corpus de estudo, detectamos o termo desverticalização, cujo sentido alcançado metaforicamente é o da especialização, significando em Economia a terceirização de alguns setores, tais como da indústria automobilística. Essa unidade linguística também pode variar sinonimicamente para horizontalização. A seguir, um dos contextos extraídos de nosso material:

Esses elementos possibilitaram às grandes empresas multinacionais maior controle e expansão de seus ativos em escala internacional a partir de dois mecanismos: i) por meio da expansão crescente de suas filiais (novas unidades) descentralizadas territorialmente, tendo o investimento direto externo (IDE) como principal instrumento; e ii) por meio do processo de terceirização da atividade produtiva, configurando novas formas de organização industrial em que ocorrem a 'deslocalização' e a <desverticalização> do processo manufatureiro de partes e componentes, que antes eram produzidos na fábrica central do grupo, para empresas juridicamente independentes e em outros espaços 
nacionais. A grande companhia (especialmente a que possui o brand) estabelece controle significativo sobre o processo produtivo de outras empresas, sem que tenha de absorvêla para isso (HIRATUKA; SARTI, 2010; OECD, 2013; UNCTAD, 2013). (PINTO, E. C.; GONÇALVES, R. Globalização e poder efetivo: transformações globais sob efeito da ascensão chinesa, 2015)

\title{
e) lateralidade
}

Metáforas do tipo "central/periférico" também não são muito produtivas. Podemos mencionar os termos andar de lado e a sua redução sintagmática de lado, que são de caráter orientacional periférico, pois de lado implica o conceito de afastamento do centro através desse tipo de movimento. De acordo com Sandman (1992, p. 43), essas são formações exocêntricas, posto que nem andar nem de lado têm expressão linguística relativa à área de Economia em seus referentes (andar e lado), fazendo analogia a uma situação em que não há uma tendência clara de elevação ou de baixa no mercado financeiro. Abaixo, podemos visualizar o termo andar de lado, localizado em um dos textos prospectados neste corpus de estudo:

\begin{abstract}
A loja que a Louis Vuitton inaugurou no fim do ano passado em Ipanema, no Rio, consumiu 9 milhões de reais em sua construção. Nunca a grife francesa tinha gasto tanto dinheiro numa filial no lado de baixo do Equador. Há uma boa explicação para tal gastança, que inclui piso de mármore importado da Itália: os brasileiros estão entre os mais ávidos consumidores de suas caríssimas bolsas, malas e acessórios. São eles que compram sete de cada dez produtos da grife vendidos na América Latina. Entre as 320 lojas da marca existentes em todo o mundo, aquela instalada no Shopping Center Iguatemi, em São Paulo, apresenta o quinto maior faturamento por metro quadrado. $\mathrm{O}$ impressionante sucesso da Louis Vuitton é reflexo de um paradoxo nacional. A economia <anda de lado> e o PIB praticamente estagnou em 2003. O comércio de alto luxo, por sua vez, vive uma fase de espetacular expansão. (GIMENEZ, D. M. A questão social e os limites do projeto liberal no Brasil, 2007)
\end{abstract}

De acordo com Kuntz, do Observatório da imprensa na Internet (http:// www.tvebrasil.com.br), ${ }^{72}$ algumas metáforas usadas pelo jornalismo econômico, como as do tipo orientacional ou as ontológicas, não fazem o menor sentido, constituindo-se em um "abuso do processo de personificação" dos termos. Diante dessa afirmação, podemos nos questionar se esse mesmo descomedimento ocorre na linguagem usada pelos especialistas da Economia: do ponto de vista cognitivo, podemos afirmar que isso não

\footnotetext{
72 Acesso em 14 jul. 2019.
} 
acontece, pois essas metáforas são tomadas como elementos conceptualizadores de algum tipo de fenômeno.

A seguir, o comentário de Kuntz sobre esse assunto:

O dólar subia ou caía, valorizava-se ou desvaloriza-se, quando se escrevia em português, hoje em dia o dólar opera em baixa ou em alta, assim como o índice Bovespa. Ora, dólar não opera. O mercado opera, vá lá, mas não a moeda, nem o índice. [...] O 'dólar de lado' é uma das formas de animação do noticiário econômico. Algumas são expressivas e justificáveis, outras nem tanto.

Demonstraremos na imagem a seguir a distribuição de metáforas da Tabela 4 que se referem a conceitos de espacialização. Observando a frequência de cada um desses conceitos, constatamos que as metáforas mais produtivas são, maciçamente, as relacionadas a "fundo"; em segundo plano, a "alto/baixo"; em terceiro, a "vertical/horizontal"; em quarto e quinto lugares, "central" e "lateral", respectivamente. 
Gráfico 3 - Representação dos resultados da Tabela 3

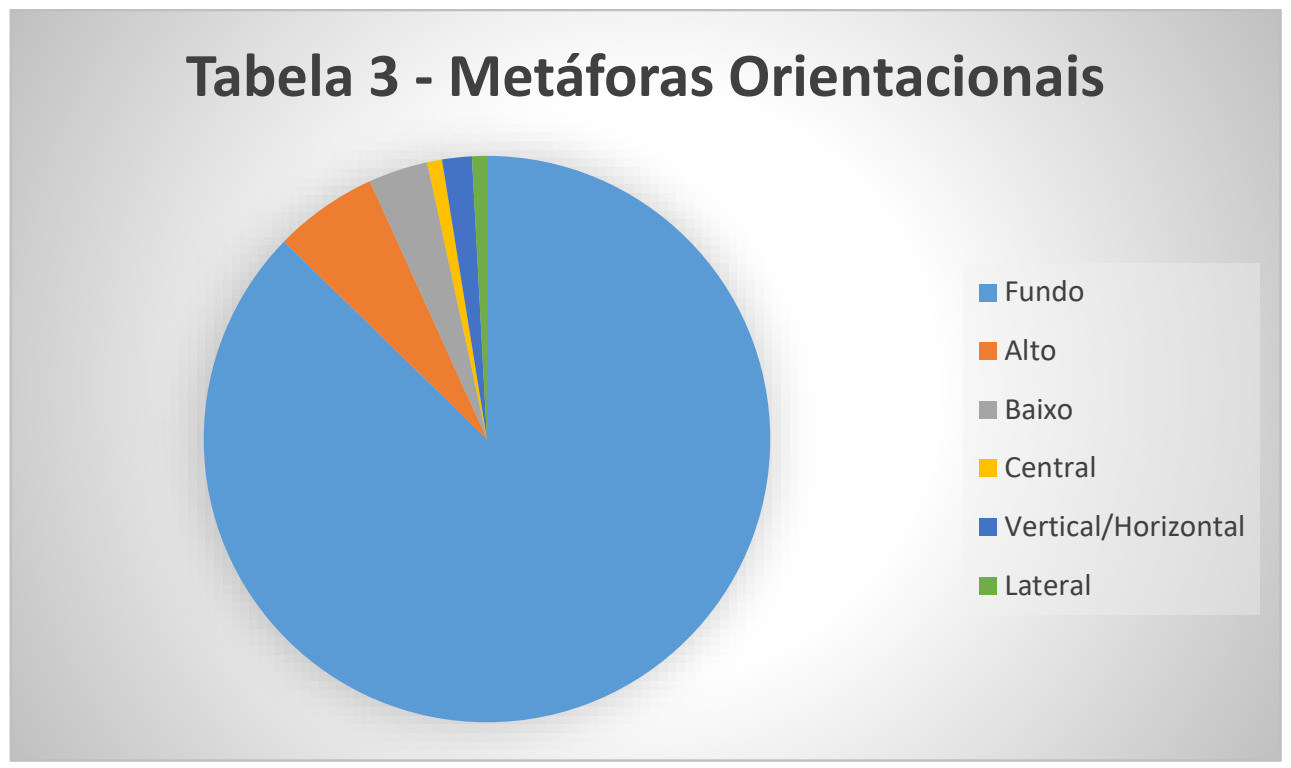

Os mapeamentos acima projetados e a sua frequência nos levam a afirmar que, em primeiro lugar, os conceitos espaciais relacionados a "fundo" constituem um domínio positivo, porquanto fundo é um dinheiro que serve para algum tipo de investimento. Em uma sociedade capitalista, as aplicações são praticadas a todo momento a fim de aumentar a rentabilidade de seus aplicadores. Em segundo lugar, apresentando uma frequência muito baixa no que se refere a fundos, aparecem as projeções relacionadas aos conceitos "para cima" e "para baixo". Esses partem sobretudo da ideia de que a orientação "para cima" indica progresso, bem-estar, poder, enquanto no caso de "para baixo" se estabelece precisamente o inverso desses itens relacionados.

Os demais termos com baixíssima produtividade revelam conceitos relacionados a aspectos positivos ou a apenas uma projeção orientacional, cujo objetivo é facilitar a visualização de um processo, como é o caso de desverticalização e horizontalização, ou ainda "lateralidade", chancelado pela expressão linguística andar de lado, que expressa uma falta de clareza em relação à tendência de elevação ou de baixa no mercado financeiro.

\section{$\underline{\text { As metáforas apresentadas em outros domínios }}$}

Em relação aos domínios previamente comentados, faremos, a seguir, uma análise de cada um deles apresentados na Tabela 4, levando-se em consideração a relevância e a frequência dos termos apresentados. 


\section{a) náutica ou movimentos da água}

O conceito ECONOMIA É NÁUTICA denomina 43 termos metafóricos de nossa pesquisa, representando quase $5 \%$ do total dessas unidades. Esses termos são, por exemplo, âncora cambial, âncora fiscal, flutuação, flutuação cambial, flutuação da economia, flutuação da taxa de câmbio, emergente, mercado emergente. Esse domíniofonte é transposto para a Economia a partir de projeções do tipo ECONOMIA É NAVEGAÇÃO ou MOVIMENTOS DA ÁGUA, cuja base cognitiva repousa no fato de que há algumas situações ocasionadas na Economia que precisam se estabilizar comparativamente a um barco ou a um navio que oscila no mar, e que precisa ancorar em algum momento. Um de nossos exemplos refere-se à unidade âncora fiscal, que significa um rol de medidas cuja finalidade é manter a Economia "estável” pela contenção dos gastos públicos. O traço semântico saliente nessa formação metafórica é o da estabilidade.

O movimento alternativo de "baixa" ou "alta" de valores de mercadorias nas bolsas e nos mercados é responsável por designar os termos, como, por exemplo, flutuação. No site https://conceito.de/flutuacao, esse termo é definido como a oscilação de uma divisa (moeda) cuja cotação varia de acordo com os movimentos do mercado, já que não existe nenhuma taxa de câmbio fixada pelo Estado. Essa definição faz referência ao mesmo tempo à oscilação e à fixação, ou seja, a movimentos "náuticos" que ocorrem na água antes de um barco ancorar (ou seja, se fixar). O esquema imagético projetado nessa metáfora é o de uma "moeda" que pode oscilar como um "barco" de acordo com os movimentos inconstantes do mar. Verifiquemos a seguir alguns desses termos contextualizados:

\section{- âncora cambial}

Contudo, a crise cambial foi seguida por mudanças na política macroeconômica que, finalmente, completaram o "enquadramento" da economia brasileira ao modelo de liberalização, a saber: a) a política de ampla abertura financeira e comercial foi mantida e, no primeiro caso, até aprofundada; b) a <âncora cambial> foi substituída pelo regime de câmbio flutuante; c) a política monetária passou a ser regida por um modelo de metas de inflação; d) a política fiscal passou a ser orientada por um modelo de metas de superávit primário e, a partir de meados de 2000, também pela Lei de Responsabilidade Fiscal, que institucionalizou, para as três esferas de governo, regras de conduta para a formulação e execução orçamentária, visando controlar, de forma permanente, o endividamento do setor público. 
(HERMANN, J. Liberalização e desenvolvimento financeiro: lições da experiência brasileira no período 1990-2006, 2010)

\title{
- flutuação cambial
}

\begin{abstract}
Em relação à adoção de uma união monetária, Eichengreen, Tobin e Wyplosz (1995) ressaltam que a <flutuação cambial> não é inevitável, pois as relações financeiras e comerciais com os países que não integram a união monetária não são eliminadas. Por outro lado, embora a <flutuação cambial> permita maior poder de discrição às autoridades monetárias, não deve ser desprezado o custo referente ao possível distanciamento da taxa de câmbio em relação à sua taxa de equilíbrio. (MENDONÇA, H. F. de; PIRES, M. C. de C. Liberalização da conta de capitais e inflação: a experiência brasileira no período Pós-Real, 2006)
\end{abstract}

\section{b) contêiner}

De acordo com Lakoff e Jonhson (2002, [1980], p. 81), algumas imagens estruturantes de Modelos Cognitivos Idealizados (MCIs) - relações existentes entre o funcionamento da mente e experiências do corpo com o mundo do qual emergem nossos sistemas conceptuais humanos - são oriundas de nosso sistema corpóreo. Para esse tipo de compreensão, eles idealizaram o modelo cognitivo da metáfora do "contêiner", conceito demarcador de fronteira também utilizado para as noções de interior e exterior. De acordo com esses autores, somos seres físicos, demarcados e separados do resto do mundo pela superfície de nossas peles; experienciamos o resto do mundo como algo fora de nós. Somos um recipiente de uma superfície delimitadora de orientação "dentro-fora". Marcamos fronteiras e uma superfície restrita capazes de revelar nosso instinto mais básico de territorialidade em um ato de quantificação desses limites. ${ }^{73}$

No esquema imagético do "contêiner", localizamos, dentre os termos estudados, lexicalizações metafóricas como capital aberto e fechado, fundos fechados, empresas de capital fechado, nicho de investimento, nicho de mercado, piso, piso nacional, piso dos benefícios previdenciários, teto, teto salarial, teto de benefícios, barreira tarifária, fronteira de produção estocástica, margem, margem líquida. ${ }^{74}$ São 21 unidades metafóricas geradas a partir desse conceito, representando em termos de porcentagem o valor de $2 \%$.

\footnotetext{
73 Para Lakoff; Johnson (2002, [1980]), essas metáforas são ontológicas, pois são formas de se conceber eventos, atividades, emoções, ideias etc. como entidades e substâncias.

${ }^{74}$ Nas formações sintagmáticas, tais como fronteira de produção estocástica, marcamos em itálico o vocábulo que corresponde à metáfora do contêiner.
} 
Se a Economia é um "recipiente" ou um "contêiner" que pode estar "aberto ou fechado", ela pode evidenciar termos como capital aberto, capital fechado e empresas de capital fechado. No caso de capital aberto, essas projeções referem-se a corporações, cujos acionistas são anônimos. O capital nesse caso é formado por ações negociadas livremente nas Bolsas de Valores. Na denominação capital fechado, o conceito faz referência à sociedade anônima, cujo capital social representado pelas ações está normalmente dividido entre poucos acionistas.

Com o objetivo de demarcar valores que não podem ir mais abaixo e nem ir mais acima, surgem unidades terminológicas metafóricas constituídas com piso - por exemplo, piso salarial (menor valor de salário que pode ser pago dentro de uma categoria profissional específica) - e teto - como teto de benefícios (maior valor dos benefícios previdenciários). Nesses exemplos, o conceito do "limite" é mapeado nas expressões linguísticas. A seguir, um dos termos contextualizados no corpus analisado:

\begin{abstract}
A reforma de 2003 seguiu a orientação principal da reforma de 1998, procurando melhorar o equilíbrio financeiro do sistema previdenciário público. Uma diferença, no entanto, é que ela se concentrou basicamente no RPSP. O RGPS não foi alterado, com exceção da regra que aumentou o <teto dos benefícios> (passou a ser de $\mathrm{R} \$ 2.400$ na época da aprovação da Emenda $\mathrm{n}^{\circ}$ 41). (UEDA, D. M. Sistema previdenciário brasileiro: aspectos macroeconômicos e distributivos, 2005)
\end{abstract}

As unidades fronteira de produção estocástica e margem líquida são mapeamentos metafóricos usados para demarcar fronteiras e uma superfície delimitada, revelando conceitos relacionados à territorialidade. O termo fronteira de produção estocástica concerne a métodos mais utilizados no estudo da eficiência relativa de unidades produtivas através da representação da fronteira do conjunto de possibilidades de produção, ao passo que margem líquida significa a porcentagem de lucro líquido em relação ao total do faturamento (SANDRONI, 2005, p. 512).

A seguir, um dos contextos dos termos acima citados, ilustrado por margem líquida, cuja metáfora margem delimita a dimensão de uma parte de um lucro a ser obtido de um determinado montante:

\footnotetext{
O setor de comércio seguiu a tendência da indústria e apresentou redução da <margem líquida>, enquanto o setor de serviços foi novamente o que apresentou melhor desempenho em todos os segmentos - exceção feita para o segmento de energia no ano de 2008 que novamente apresentou queda de margem líquida. (FILLETI, J. de P. Financiamento de empresas nãofinanceiras de capital aberto no Brasil: proposição de uma abordagem quantílica, 2010)
} 
Por último, comentaremos a metáfora do "nicho", que pode também ser categorizada como uma metáfora do "contêiner", porquanto compreende-se nessa projeção aquilo que pode ser colocado dentro de uma reentrância. A analogia estabelecida consiste em fazer referência à delimitação de um espaço físico. No Dicionário de economia do século XXI (2005, p. 594), nicho é definido como um termo que pode designar uma faixa de mercado ocupada por uma empresa em sua estratégia empresarial, conhecido normalmente como nicho de mercado, conforme demonstra o contexto a seguir:

\begin{abstract}
A disputa dos grandes bancos no Brasil pelo crédito massificado também se estendeu para o campo da aquisição de financeiras e de bancos com <nicho de mercado> no crédito ao consumo, bem como para a esfera da realização de contratos de cessão de crédito com instituições de pequeno e médio portes". (OLIVEIRA, G. C. de. Estrutura patrimonial e padrão de rentabilidade os bancos privados no Brasil [1970-2008]: teoria, evidências e peculiaridades, 2009)
\end{abstract}

\title{
c) objeto
}

Nesse tipo de domínio, reunimos termos que apresentam forte inclinação à metonímia conceptual, tornando difícil a nossa decisão sobre a classificação entre um ou outro processo semântico-cognitivo. Como já dissemos anteriormente, existem processos nos quais ocorre a interação entre metáfora e metonímia, com uma podendo motivar a outra e vice-versa. O cruzamento vocabular metaftonímia, utilizado por Silva (2003, p. 51), denomina esse tipo de continuum.

O termo caixa, responsável por lexicalizações como fluxo de caixa positivo, pode ser interpretado por alguns estudiosos como a metáfora do "contêiner", representando a noção de estar "dentro" de um objeto. No caso de caixa, essa projeção pode ser interpretada como um tipo de metonímia, uma vez que se representa o objeto pela função de "guardar dinheiro". Esse tipo de situação pode ocasionar o fenômeno da metaftonímia.

A metonímia pode ser representada por diversas categorias, tais como PARTE PELO TODO, EFEITO PELA CAUSA, CONTINENTE PELO CONTEÚDO, LOCAL/OBJETO PELO EVENTO, METONÍMIAS FISIOLÓGICAS e OBJETO PELA FUNÇÃO (SILVA, 2003, p. 48-52). A seguir, comentaremos alguns desses casos localizados no corpus analisado:

\section{- colchão}


O termo colchão de liquidez, encabeçado pela metaftonímia do "colchão", denomina em Economia uma reserva estratégica de proteção do Tesouro Nacional para enfrentar situações de alta volatilidade no mercado financeiro (SANDRONI, 2005, p. 158). Nesse contexto, o "colchão" significa um "amaciamento", no caso de uma queda, ou seja, se a Economia não vai bem por causa do mercado financeiro, é necessário um “colchão" para "amaciar" essa queda, de forma que são necessárias reservas monetárias para a sobrevivência desse impacto. O conceito mapeado nesta metaftonímia é o da "proteção" e do "amortecimento", por isso a denominação colchão de liquidez é encontrada neste corpus também com a forma sinonímica de colchão amortecedor, na qual o emprego do adjetivo amortecedor torna o significado da metáfora do "colchão" mais transparente. Do ponto de vista metonímico, a categoria representada é a do EFEITO PELA CAUSA, porquanto o efeito da reserva obtido por qualquer instituição ou pessoa pode proteger de uma perda monetária causada por algum imprevisto ou uma necessidade específica e imediata.

\section{- moeda-chave}

No caso de "chave", do ponto de vista metonímico, categoriza-se o OBJETO PELA FUNÇÃO. De acordo com Sandroni (2005, p. 567), moeda-chave é um tipo de dinheiro utilizado para o cálculo de paridade entre duas outras moedas. Em relações comerciais internacionais, costuma-se utilizar o dólar como moeda-chave nas trocas entre países com poucas relações comerciais. No Dicionário Houaiss da língua portuguesa (2001, p. 2005), há várias definições para esse vocábulo com sentido metafórico (p.metf.), cujo sentido mapeado para tal tipo de conceito, em nosso corpus de estudo (acepção 6), refere-se a "elemento essencial para o equilíbrio, a firmeza, a eficiência de um sistema, uma organização, uma teoria".

Uma moeda-chave, do ponto de vista econômico, é essencial para as relações comerciais internacionais, pois ela é aceita como meio de pagamento. Logo, podemos afirmar que estamos diante de outra metaftonímia: é uma metonímia porque esse tipo de moeda é um tipo de "objeto" que cumpre uma determinada função, servindo de cálculo de paridade, mas é também uma metáfora, pois o domínio projetado refere-se ao conceito de "chave" como elemento essencial para as relações comerciais internacionais.

Por último, em relação a "leque", identificamos dois termos (leque salarial e leque de ativos) expressos por essa metáfora que pode ser interpretada também como 
metonímia, uma vez que o mapeamento metafórico ocorre através da imagem das "repartições" que um "leque" pode conter, significando comparativamente, de acordo com o HOUAISS (2001, p. 1744) p.ana. "qualquer coisa que tenha a forma de um leque quando aberto ou um conjunto de coisas dispostas".

Em Economia, leque salarial é um conceito utilizado para avaliar como o rendimento de um país é repartido pela população, servindo de base para calcular as desigualdades existentes em um país; indicador que mostra a relação entre o salário máximo e o mínimo em vigor em um país, em uma categoria profissional e em uma empresa. Nesse tipo de termo metafórico, o que é mapeado é o aspecto semântico da repartição através da projeção da imagem do "leque", objeto de abano feito de material leve fixo por lâminas móveis que ocasionam a sua divisão em partes. Do ponto de vista metonímico, projeta-se nesse processo semântico o SÍMBOLO PELO SIMBOLIZADO, categoria metonímica também proposta por Lakoff e Johnson (2002, [1980], p. 97), em que "leque" simboliza a repartição, e, nessa terminologia econômica, a repartição de rendimentos. A seguir, apresentamos o termo contextualizado para que possamos compreender de forma satisfatória o seu sentido:

\begin{abstract}
Esse modelo de economias de altos e baixos salários sofreu grandes mudanças durante a década de 1970, com a desestabilização da economia mundial causada pelo fim do acordo de Bretton Woods e os choques do petróleo, que colocaram a economia mundial num período de instabilidade. Com a transformação da microeletrônica, gerou-se um novo padrão de desenvolvimento econômico, que alterou sobremaneira a dinâmica salarial construída a partir do padrão industrial fordista, em especial nos Estados Unidos, com crescente migração dos empregos industriais para o setor de serviços. Isso provocou um aumento do <leque salarial> justamente por basear o crescimento num setor que não fazia parte do núcleo dinâmico do capitalismo americano na 'Era de Ouro', portanto, sem a existência de ligações dinâmicas intrassetoriais como aconteceu com a indústria. (HORIE, L. Considerações sobre política econômica e salários: especificidades do caso americano no pós $2^{a}$ Guerra Mundial, 2007)
\end{abstract}

No cômputo geral, esse conceito não é muito produtivo neste corpus estudado, representando apenas $1,5 \%$ das metáforas licenciadas (13 termos), sendo que muitas delas são metaftonímias.

\title{
d) belicismo
}

O domínio ECONOMIA É BELICISMO ou ECONOMIA É GUERRA é um tipo de conceito que também se destaca na Economia. Para compreender o significado de cada 
uma dessas lexicalizações, é necessário pontuar que a concorrência existente no mundo corporativo é altamente acirrada. Por exemplo, muitos administradores de empresa e economistas leem em seu processo de formação profissional o livro A arte da guerra, escrito por Sun Tzu no século IV a.C., com o intuito de se inspirarem em táticas de estratégia militares para o mundo dos negócios, o que demonstra claramente o alcance desse conceito nos domínios metafóricos da Economia. Mapeando esses domínios no universo de metáforas estudadas neste corpus, encontramos onze metáforas belicistas que representam a porcentagem de $1,2 \%$ do montante analisado, tais como: ataque especulativo, ataque de autorrealizáveis, guerra comercial, guerra de preços, guerra fiscal, guerra de moedas, entre outras.

No esquema imagético da "guerra", ocorrem também "ataques", logo, lexicalizações metafóricas, a exemplo de ataque especulativo, compreendendo um tipo de investidura contra a moeda local de um país. Dos vários termos cunhados a partir de guerra, podemos destacar, por exemplo, guerra fiscal, que conceitua uma concorrência desencadeada pelo interesse de cada Estado brasileiro em oferecer algum tipo de vantagem fiscal para atrair investimentos externos.

Esse domínio, projetado do domínio-fonte "guerra" para o domínio-alvo da Economia, dá força expressiva e também apelativa aos termos, combinando uma explicação simples com fortes efeitos emocionais. Abaixo, alguns desses termos contextualizados:

\section{- ataque especulativo}

Ocorrendo, em geral, à esteira de processos de liberalização financeira e da conta de capital, esses booms usualmente envolvem ingressos vultosos de capital externo, razão pela qual são acompanhados de uma apreciação da taxa de câmbio real que, junto com a elevada liquidez doméstica, aumenta a probabilidade de um <ataque especulativo> contra a moeda doméstica e, por conseguinte, de uma crise bancária. Na maioria dos casos, a fragilidade radica na deterioração prolongada da qualidade dos ativos dos bancos, decorrente da avaliação negligente dos riscos de empréstimos a projetos de investimento durante o boom. (ALDRIGHI, D. M.; CARDOSO, A. D. Crises cambiais e financeiras: uma comparação entre América Latina e Leste Asiático, 2009)

- guerra fiscal

Na década de 1990 muitas unidades da Federação concederam isenções tributárias para atrair investimentos. No ambiente competitivo da economia 
brasileira após 1997, a pesquisa comparativa avalia o impacto da guerra fiscal nas receitas do ICMS, na geração de postos de trabalho na indústria e no PIB por setor, comparando-se o Estado de São Paulo com outros Estados da Federação. Foram utilizados dois modelos econométricos, um que compara alterações nas variáveis entre os Estados e entre os períodos, antes e após a <guerra fiscal>, e o outro, que capta mudanças na taxa de crescimento das variáveis entre os períodos. As estimativas mostram que os Estados avaliados, individualmente ou em conjunto, apresentam alterações significativas na taxa de crescimento do PIB industrial, em comparação ao Estado paulista, depois da intensificação da guerra fiscal. Os mesmos resultados parecem não valer para a geração de empregos na indústria e para as receitas do ICMS. (NASCIMENTO, S. P. do. Guerra fiscal: uma avaliação comparativa entre alguns estados participantes, 2008)

\section{e) máquina ou mecanismo}

Em relação ao conceito ECONOMIA É MÁQUINA, foram prospectados sete termos, representando $0,8 \%$ das metáforas licenciadas pelas unidades terminológicas motor do crescimento e/ou motor do crescimento econômico. Nessa projeção, a Economia torna-se produtiva quando ela funciona como “máquina”. É interessante notar nesse termo que há duas metáforas: uma que compreende a Economia como "máquina”, lexicalizada pela unidade motor, e a outra, que a conceitua como "organismo" por meio da metáfora do crescimento. Apesar de haver duas metáforas no mesmo termo (motor + crescimento), preferimos categorizar a unidade motor do crescimento econômico como um domínio da "máquina", uma vez que "motor", na posição de determinado em sua constituição morfológica, encabeça o termo para, em seguida, permitir a consideração de tal processo metafórico na área da Economia. Abaixo, o termo contextualizado:

\footnotetext{
Esse aumento de salário irá atrair mão de obra do setor atrasado, o que acarretará um aumento da produtividade desse setor devido à redução do excesso de oferta de trabalho. Assim, ao reduzir a quantidade de trabalho empregado no setor atrasado (baixa produtividade), a expansão do setor industrial aumenta a produtividade dos demais setores e, por conseguinte, a produtividade total da economia. Associado a isso, o aumento do estoque de trabalhadores no setor industrial recebendo salários maiores provoca aumentos na demanda, o que causará novos aumentos na produção, reiniciando, assim, o processo de crescimento. Dessa forma, o crescimento econômico dos países é liderado por um conjunto de interações no qual o setor industrial se caracteriza como o <'motor do crescimento'>, pois a expansão da demanda nesse setor consegue induzir o aumento da produtividade em todos os setores da economia (McCombie; Thirlwall, 1994). (MISSIO, F. J.; Jayme Jr., F. G. Restrição externa, nível da taxa real de câmbio e crescimento em um modelo com progresso técnico endógeno, 2013)
}

Outra unidade que consideramos como uma evidência linguística desse tipo de conceito é rolagem de dívidas. "Rolagem", de acordo com o dicionário Houaiss (2001, 
p. 2.469), é um tipo de mecanismo utilizado para guiar um movimento de rotação ou o deslocamento de um corpo que gira em contato com outro sem deslizar. No jargão financeiro, "rolagem" equivale a empurrar uma dívida para diante (SANDRONI, 2005, p. 744). Ou seja, o processo de adiar o pagamento de uma dívida está associado a um tipo de procedimento que é compreendido em termos de "mecanismo".

No que se refere ao termo alavancagem, Berber Sardinha (2007, p. 109) considera-o também como um domínio-fonte da "máquina", pois, para o autor, a "alavancagem" é realizada por uma máquina denominada alavanca. Porém, conforme já comentamos anteriormente, consideramos a "alavancagem" como um processo físico, pois se trata de um tipo de força que é usada para levantar algum objeto, sendo que a alavanca é apenas um instrumento utilizado para fazer esse procedimento.

No caso de "turbulência", os termos turbulência dos mercados financeiros ou turbulência financeira foram mapeados como metáforas cognitivas da "máquina", pois a turbulência ocorre devido ao contato do "motor (máquina) turbo" com a água, provocando a sua agitação, logo a turbulência. Porém essas metáforas poderiam ser facilmente ser categorizadas como projeções cognitivas da NÁUTICA ou da AERONÁUTICA, uma vez que no caso da AERONÁUTICA a turbulência ocorre quando há um escoamento de ar em turbilhão ao longo da asa do avião, em vez de água, como no caso NÁUTICA.

\section{f) metáforas zoomórficas}

De acordo com Kövecses ${ }^{75}$ (2005, apud Cavalcanti; Pelosi, 2016, p. 276), as metáforas zoomórficas são um procedimento cognitivo produtivo e primevo que fornece uma base metafórica para conhecidos e antigos processos antropológicos, como o totemismo, em que os animais são definidos a partir de atributos instintivos e comportamentais. Tigres, por exemplo, são animais de grande porte que apresentam baixo grau de domesticidade, e, portanto, são agressivos. Do ponto de vista da projeção metafórica, essa é a característica principal mapeada nos termos empregados em Economia para se referir às economias de Hong Kong, Singapura, Coreia do Sul e Taiwan, as quais apresentaram taxas de crescimento e rápida industrialização entre as décadas de 1960 e 1980. Essas unidades revelam o aspecto semântico da agressividade à medida que esses países empregaram estratégias arrojadas de atração de capital

\footnotetext{
${ }^{75}$ KÖVECSES, Zoltán. Metaphor in culture: universality and variation. Nova York: Cambridge University Press, 2005.
} 
estrangeiros, apoiadas na mão de obra barata e disciplinada, isenção de impostos e nos baixos custos de instalação de empresas.

Sendo assim, tigres asiáticos são conhecidos por seu dinamismo e pela forma com que lidam com sua Economia e se relacionam com a Economia mundial de forma agressiva. Outra metáfora zoomórfica que se refere ao crescimento econômico, nesse caso na Irlanda do século XX, é a do tigre celta. Vejamos, a seguir, o contexto em que uma dessas metáforas animais ocorre neste corpus de estudo com a frequência de cinco termos, correspondendo ao valor de $0,5 \%$ :

\begin{abstract}
Contudo, o período de crescimento acelerado transformou a economia irlandesa, fazendo-a deixar a década de 80 como uma das economias mais pobres da Europa e adentrar à primeira década do século $20 \mathrm{com}$ a terceira maior renda per capita do 5 mundo (GODOI, 2007). As elevadas taxas de crescimento renderam à Irlanda o apelido de $<$ 'Tigre Celta' $>$ em alusão aos <'Tigres Asiáticos'>. (OLIVEIRA, R. S. de. O tigre celta: a economia irlandesa desde a década de 90 - uma investigação sobre o modelo de inserção econômica, 2009)
\end{abstract}

\title{
g) higiene
}

Responsável por apenas $4 \%$ dos termos metafóricos, gerando quatro unidades metafóricas localizadas neste corpus de análise, verificamos o sexto conceito mais produtivo da Tabela 4, que é o da ECONOMIA É HIGIENE. Esse tipo de domínio permite licenciar as unidades linguísticas flutação suja, regime de flutação suja e lavagem de dinheiro.

A lavagem de dinheiro é um termo que se refere a práticas econômico-financeiras cuja finalidade é esconder ou dissimular a origem ilícita de ativos financeiros ou bens patrimoniais, de forma que aparentem ter uma origem legal. Essa metáfora é um decalque do inglês money laundering, que significa "lavagem" ou "branqueamento de dinheiro" no contexto histórico em que ela surge.

Ela tem origem no fato de que o dinheiro adquirido ilicitamente é "sujo", e, portanto, deve ser "lavado" ( ou "higienizado") para se tornar "limpo". O conceito que está sendo ativado nessa projeção analógica é do tipo ECONOMIA É HIGIENE, dotando de valor moral a metáfora empregada, pois "sujeira”, em nossa cultura, pode conotar algo desonesto. Por sua vez, as metáforas que designam um processo no qual a taxa de câmbio de um país sofre intervenções no mercado pelas autoridades monetárias desse país, especialmente o Banco Central, são denominadas flutuação suja ou regime de flutuação 
suja (SANDRONI, 2005, p. 254). O que é mapeado metaforicamente nesses dois termos é o fato de que esse tipo de intervenção dos bancos nos mercados de câmbio não reflete, frequentemente, as reais condições econômicas de um país, mascarando um tipo de realidade, revelando a conotação moral atribuída ao termo em que "sujo" aparece com valor adjetival. O contrário da flutuação suja é a flutuação limpa, política cambial que não envolve a intervenção de autoridades monetárias.

Notam-se também nessas unidades citadas acima a presença de duas metáforas: a primeira, que compreende o mercado de câmbio como "flutuação" (conceito da náutica ou do movimento para mapear o aspecto cognitivo que explica a "oscilação" das moedas), e a outra metáfora, que conceitua a Economia em termos de "higiene". Como já tínhamos analisado o domínio da "flutuação", decidimos comentar o conceito de "higiene" pelo fato de ele pertencer a outro campo cognitivo que não é o mesmo da "flutuação". A seguir, um desses termos comentados em seu contexto original:

De acordo com Carcanholo (2010) a política cambial não se alterou desde o início dos anos 90. Na visão do autor a 'determinação da taxa de câmbio segue um esquema de <flutuação suja〉, ou seja, o mercado cambial determina o valor da moeda nacional em relação à moeda conversível, e o Banco Central atua no mercado, ora comprando, ora vendendo, de forma a tentar manter essa flutuação da taxa de câmbio, segundo os parâmetros que lhe parecem convenientes'. A gestão da política cambial não se alterou e, de certa forma, permitiu que o câmbio se apreciasse, prejudicando a atividade industrial nacional no sentido da substituição de produtos nacionais por importados. Esse quadro se reflete na elevação expressiva das importações a partir de 2003, no bojo do movimento de apreciação cambial. (TROVÃO, C. J. B. M. Exportações e mercado doméstico: a criação de um ambiente favorável ao emprego formal 2002-2008, 2012) 


\title{
h) regiões geográficas
}

No campo conceitual das REGIÕES GEOGRÁFICAS SÃO VARIAÇÕES DE ALTITUDE, ${ }^{76}$ localizamos quatro termos $(0,4 \%)$. As unidades terminológicas metafóricas pico e pico de renda designam, respectivamente, um "ponto máximo atingido por uma variável econômica ou financeira" e "medida de poder de compra" (SANDRONI, 2005, p. 641). Como se referem a pontos máximos, eis a analogia com o topo de um monte ou montanha. Nas unidades depressão econômica e Grande Depressão, o domínio-fonte LOCAL pode ser concebido como REGIÃO DELIMITADA NO ESPAÇO e pico se refere ao topo, enquanto depressão ${ }^{77}$ tange à parte mais baixa de uma área em sua volta. Em Economia, a projeção metafórica estabelecida nesse tipo de analogia faz menção ao fato de que "depressão" é uma região geográfica mais baixa do que as áreas em sua volta; logo, o desenvolvimento econômico, quando está abaixo do esperado, é conceituado negativamente, como é o caso de depressão econômica. A seguir, alguns desses exemplos:

\section{- pico de renda}

\begin{abstract}
No diagnóstico de Lara Resende, são as expectativas quanto ao movimento futuro dos índices inflacionários que presidem o comportamento dos agentes econômicos. Em outras palavras, o agente de Lara Resende olha para a frente, não para trás, e isso implica no fato de que ele tem como objetivo sua renda real média, e não seu <pico de renda>. Nesse sentido, é o processo de formação de expectativas que redunda na persistência da inércia inflacionária. Dado esse comportamento dos agentes, a inflação iria se tornar inercial quando a melhor forma de se prever a inflação futura fosse a inflação passada. Essa análise de Lara Resende foi apoiada por outro expoente da PUC/RJ, Pérsio Arida. (SILVA, M. P. da. A teoria da inflação inercial, 2008)
\end{abstract}

\section{- depressão econômica}

Com base nos resultados encontrados no presente trabalho conclui-se que existiu uma relação entre a queda da extração aurífera com a economia do termo da cidade do Rio de Janeiro. Mesmo não se mensurando com precisão o grau de interferência do declínio aurífero sobre o nível de atividade carioca,

\footnotetext{
${ }^{76}$ Essas metáforas estruturais também poderiam ser agrupadas na Tabela 3 como orientacionais, pois são patentes as noções de alto, em "pico", e de baixo, em "depressão.

${ }^{77}$ É comum que esse termo seja conceituado por alguns estudiosos das metáforas da Economia, tais como Charteris-Black e Ennis (2001, p. 5), como uma projeção da medicina, pois o que é mapeado nesse caso é o aspecto da doença psicológica. Contudo, preferimos categorizar esse domínio como geográfico (algo que está abaixo da superfície), uma vez que a Psicologia faz um uso primário dessa metáfora espacial para conceituar no indivíduo algo caracterizado como distúrbio psíquico relacionado perda de interesse, estado de desencorajamento.
} 
pode-se perceber que a economia carioca não experimentou uma crise ou <depressão econômica>, mas sim uma estagnação. Além disso, verificou-se um revigoramento das atividades agrícolas fluminenses. (PESAVENTO, F. $O$ Colonial tardio e a economia do Rio de Janeiro na segunda metade dos Setecentos: 1750-90, 2012)

\section{i) artefato, jogo}

Esses conceitos foram reunidos no mesmo grupo devido à baixa frequência dos respectivos domínios em Economia, representando apenas 0,3\%, com apenas três unidades metafóricas para cada uma dessas projeções. As compreensões metafóricas do tipo ECONOMIA É ARTEFATO, ECONOMIA É JOGO são tipicamente advindas de experiências cotidianas como o uso de artefatos, expresso pelas metáforas armadilha de liquidez (decalque de liquidity trap), armadilha de renda média, armadilha de lucratividade, as quais têm por função apresentar um conceito relacionado a um estratagema para fazer algo ou alguém cair em uma cilada. Em Economia, uma armadilha de liquidez ocorre quando existe uma situação em que a taxa de juros se encontra em $0 \%$, ou muito próxima a isso, e a partir desse fato ocorrem ações de política monetária para injetar mais recursos na Economia quando não se obtêm o resultado esperado; por isso a denominação desse conceito como "armadilha" (SANDRONI, 2005, p. 491).

De acordo com Sandroni (2005, p. 833), a Teoria dos Jogos pode ser considerada como a ciência da estratégia; sua missão é estabelecer a ação que os agentes (os jogadores) devem desenvolver para obter melhores resultados nos negócios, valendo-se de modelos matemáticos e lógicos. O conceito de que no ramo de negócios os melhores gestores e economistas são aqueles que se valem de estratégias matemáticas e de ordem lógica em suas ações, como se estivessem em um jogo para conseguirem os melhores resultados, gera a metáfora do jogo e a denominação dos termos teoria dos jogos, jogo de mercado e jogo financeiro. A seguir, apresentamos um desses termos contextualizado:

No trabalho mais recente, o autor usa a <teoria dos jogos> para desenvolver um modelo simplificado com dois países e um setor para explorar a entrada de uma firma num país estrangeiro como reação à entrada de firma de outro país no seu mercado local. O ponto relevante a enfatizar é que a rivalidade entre firmas é uma dimensão importante e nem sempre levada em conta nas explicações sobre as EMNs. (NONNENBERG, M. J. B; MENDONÇA, M. J. C. de. Determinantes dos investimentos diretos externos em países em desenvolvimento, 2005) 


\section{j) violência}

O domínio ECONOMIA É VIOLÊNCIA representa somente 0,2\% desse mapeamento cognitivo. Ele é evidenciado pelas expressões linguísticas estrangulamento cambial e estrangulamento externo, posto que "estrangular" é um ato violento. Em estrangulamento cambial, por exemplo, designa-se um fenômeno que ocorre quando o país é incapaz de produzir os dólares de que precisa para pagar as suas importações e outros compromissos no exterior. No caso de estrangulamento externo, estamos falando de qualquer obstáculo que diminua, freie ou impeça o crescimento externo da Economia, de acordo com o que podemos verificar em um dos contextos extraído de nosso corpus:

Conforme Furtado (1959, p.283), 'a procura por bens de capital cresceu exatamente numa etapa em que as possibilidades de importação eram as mais precárias possíveis'. Assim, o período caracterizou-se pelo aumento da capacidade industrial instalada associado a um <estrangulamento externo> que limitava a autonomia da indústria nacional. (LOPES, I. R. Reestruturação industrial no Brasil: uma análise da dinâmica comercial e produtiva da economia, 2011)

\section{k) arbitragem}

Assim como ECONOMIA É VIOLÊNCIA, o domínio ECONOMIA É ARBITRAGEM representa apenas $0,2 \%$ dessa projeção. Em relação aos termos arbitragem e arbitragem regulatória, o conceito de arbitragem refere-se a uma atividade no mercado financeiro consistente em comprar mercadorias - especialmente em moeda estrangeira - em uma praça e vendê-la em outra por preço maior. Esse tipo de transação tende a igualar o preço nas duas praças em questão, exercendo dessa maneira uma função regularizadora nos mercados. Esse é o caso de uma mesma ação que, cotada em dois mercados, é adquirida pelo "arbitrador" ("mercadores") no mercado em que esse ativo estiver cotado a preço mais baixo e vendida no outro mercado por um valor maior, obtendo lucro (SANDRONI, 2005, p. 44). A projeção que aparece nessa metáfora em relação ao domínio é a da função "regulatória" que uma arbitragem exerce em um processo de decisão. Abaixo, apresentamos um dos exemplos dos textos prospectados em que o termo aparece:

Apesar do acerto das conclusões, o núcleo teórico da argumentação de Barbon não é isento de dubiedades. Como vimos, a ideia de que o valor do dinheiro é 
definido pela legislação vê-se logo atenuada pela admissão de que existe uma margem definida e não muito larga para a "valorização do dinheiro" regularmente praticada pelos estados.21 Os movimentos de <arbitragem> policiam os valores das moedas nacionais. O "par of money", a princípio considerado dependente apenas do valor estampado às peças monetárias, afinal não pode afastar-se tanto assim do conteúdo metálico das moedas. (COUTINHO, M. C. Barbon versus Locke sobre o valor da moeda, 2011)

\section{l) conceitos com baixa produtividade $(0,1 \%)$}

Por último, analisaremos domínios que apresentam somente um termo para alguns conceitos que emergem de nosso cotidiano e são transplantados para a Economia:

- ECONOMIA É ESTADO CIVIL - capaz de gerar o termo descasamento de moedas, que diz respeito ao endividamento em determinada moeda para financiar investimentos, apresentando como retorno em uma moeda distinta;

- ECONOMIA É RELIGIÃO OU CRENÇA - responsável pelo licenciamento das unidades fetichismo da mercadoria ${ }^{78}$ e paraíso fiscal; esse último termo refere-se a pequenos "estados" nos quais as empresas multinacionais estabelecem sucursais, ou pessoas físicas que depositam seus recursos aproveitando-se de impostos muito baixos ou inexistentes;

- ECONOMIA É ESCAPE - com sua fuga de capitais (quando uma pessoa ou instituição decide levar o seu dinheiro para fora do país ou de um país para outro);

- ECONOMIA É DANÇA FOLCLÓRICA e sua ciranda financeira (situação do mercado financeiro em que os movimentos especulativos são muito intensos em função da existência de um nível muito alto de incerteza econômica);

Uma das metáforas mais conhecidas nas projeções categorizadas acima é a do paraíso fiscal. Esse conceito tange lugares em que recursos financeiros são depositados por causa dos impostos baixos ou inexistentes, podendo ser conceptualizados como ECONOMIA É RELIGIÃO ou um tipo de "refúgio", que trará segurança com ótimas

\footnotetext{
${ }^{78}$ Segundo Sandroni (2005, p. 335), esse conceito é oriundo da economia marxista, consoante a qual, nas condições da produção mercantil e baseada na propriedade privada dos meios de produção, desenvolve-se a "ilusão" ou a representação ideológica de que as mercadorias são dotadas de propriedades inatas, forças "extra-humanas" que culminam na influência sobre a vida das pessoas, por isso a metáfora do "fetichismo" cujo mapeamento semântico refere-se à "religião", tratando-se portanto de uma crença.
} 
promessas de investimento; ou seja, um local onde reina a felicidade para o dinheiro dos investidores. $^{79}$

É interessante notar que nas projeções paraíso fiscal e mesmo em ciranda financeira há um tom de ironia nessas metáforas, pois o que elas traduzem, do ponto de vista conceptual e mesmo retórico, é um mundo financeiro de "prazeres". Contudo, o sentido que lhes subjazem é justamente o contrário: o de perversão financeira e econômica, pois sabemos que os paraísos fiscais são normalmente avessos à aplicação das normas de direito internacional atentas ao controle da lavagem de dinheiro. A ciranda financeira é conceituada também de uma forma positiva, comparando-a a uma dança folclórica. Porém, esse tipo de negócio é exatamente o contrário disso, pois seu funcionamento pode destruir economias e provocar empobrecimento de muitas pessoas.

A imagem a seguir demonstra a distribuição das metáforas da Tabela 4 pertencentes a outros domínios que não sejam relativos à Física e à Biologia, ou ainda às metáforas de espacialização. A frequência de cada um dos conceitos e subconceitos nos permite constatar que as metáforas mais produtivas são, em primeiro lugar, as relacionadas à "náutica ou a movimentos da água", circunscritas nas unidades polissêmicas do tipo flutuação; em segundo vem "recipiente ou contêiner", designando unidades como barreira; em terceiro lugar temos "objetos", produzindo colchão; em quarto, "belicismo" e suas lexicalizações em guerra, tal como guerra fiscal; em quinto lugar, "máquina ou mecanismo" e seus termos - por exemplo, motor da economia; em sexto, "zoomorfia", em tigre asiático; em sétimo, "higiene", lexicalizada por flutuação suja, entre outras formações, e "regiões geográficas" do tipo pico; em oitavo, temos "artefato" e "jogo"; em nono, "violência", “arbitragem” e "religião"; em décimo, "estado civil”, “escape” e “dança”, domínios esses com baixíssima produtividade $(0,1) \%$.

\footnotetext{
${ }^{79}$ Para a enciclopédia livre Wikipédia (acesso em: 8 jul. 2019), o termo paraíso fiscal vem de um erro de tradução do inglês, tax haven, que na verdade significa "refúgio fiscal". Devido à semelhança entre as palavras haven (refúgio) e heaven (paraíso), surgiu daí o paraíso fiscal.
} 


\section{Gráfico 4 - Representação dos resultados da Tabela 4}

\section{Tabela 4 - Outros Domínios}

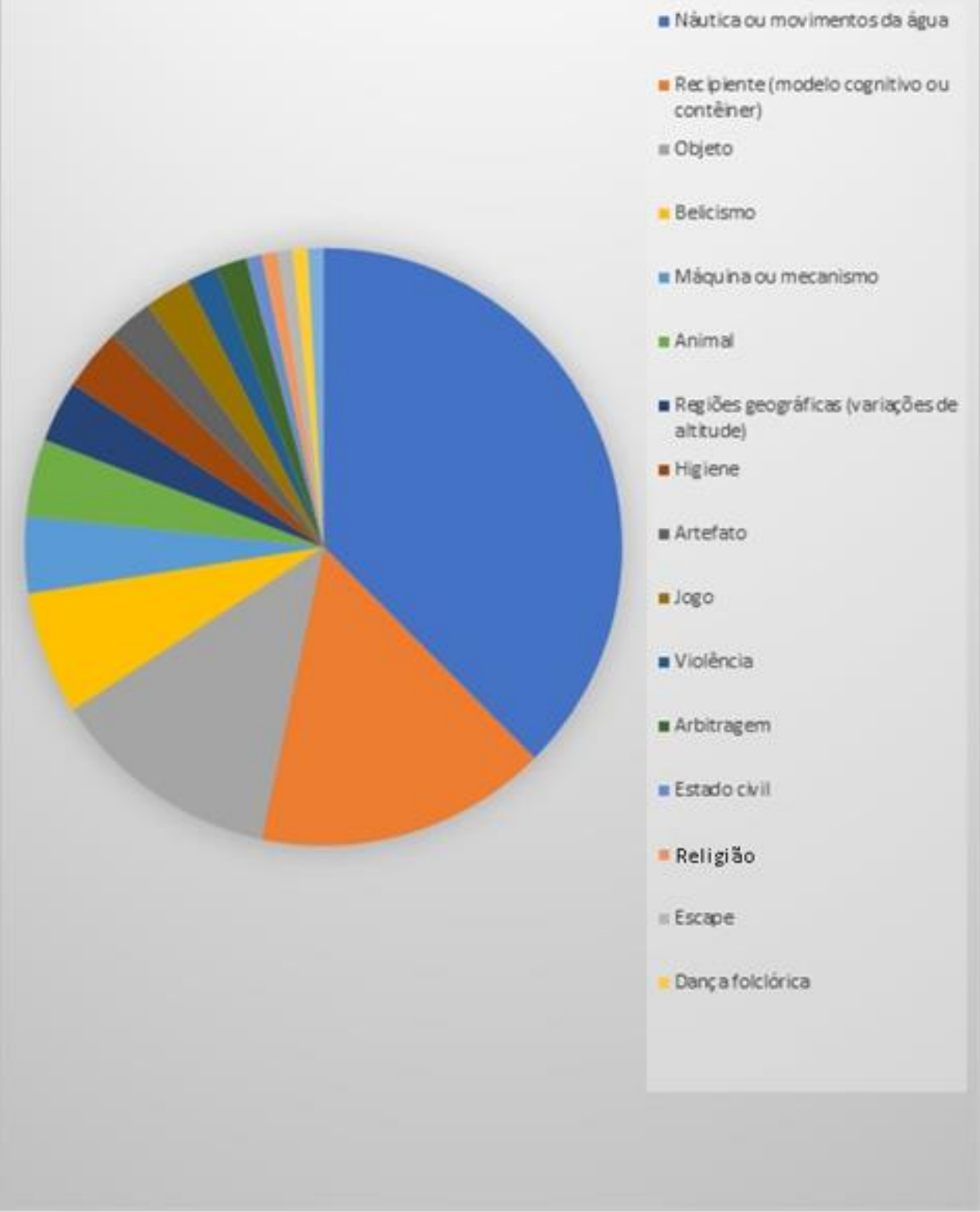

Os domínios acima projetados e a sua frequência nos permitem avaliar que os termos metafóricos ou mesmo "metaftonímicos" circuitam, em primeiro lugar, em torno de conceitos relacionados à "náutica", porquanto a estabilidade cambial é um dos elementos importantes para os movimentos do capital financeiro. Logo em seguida, demarcando fronteiras, limites, noções de "aberto" e de "fechado", como se processos e produtos econômicos pudessem ser colocados em um recipiente, ocorre a metáfora do 
contêiner, objetivando delimitar valores que não podem ir mais "abaixo" e nem ir mais “acima”. Simulando essas projeções, são geradas unidades como piso salarial. Em colchão, por exemplo, repousa a ideia de "amortecimento", como elemento de proteção em caso de perdas monetárias.

Na quarta posição aparece mapeado o domínio do "belicismo", que expressa por meio de suas unidades a alta competividade dos mercados corporativos, tal como guerra fiscal. Em seguida, "máquina ou mecanismo", metáfora que conceitua a ideia de que uma economia produtiva deve funcionar como uma máquina para que se tenha máxima eficiência. Essa conceituação produz termos a exemplo de motor da economia. As "metáforas zoomórficas" revelam a face primitiva da Economia por meio de atributos instintivos e comportamentais dessa área de conhecimento: tigres asiáticos, por exemplo, expressam o poder de potências econômicas asiáticas. Os mapeamentos em "higiene" em unidades linguísticas como flutuação suja ou flutuação limpa, revelam as reais condições econômicas de um país, se existe mascaramento ou não desse tipo de realidade e atribuindo-se, dessa forma, uma conotação moral à Economia.

Os outros conceitos com porcentagem de $0,3 \%$ ("artefato", "jogo") e $0,2 \%$ ("violência", "arbitragem" e "religião"), ou ainda de $0,1 \%$ ("estado civil", "religião", "escape" e "dança"), corroboram o fato de que as metáforas da terminologia da Economia articulam seus significados em torno de diversos campos conceituais da vida cotidiana.

Por último, chegamos ao seguinte resultado demonstrado no Gráfico 5 abaixo: 
Gráfico 5 - Resultado geral

\section{Gráfico Geral}

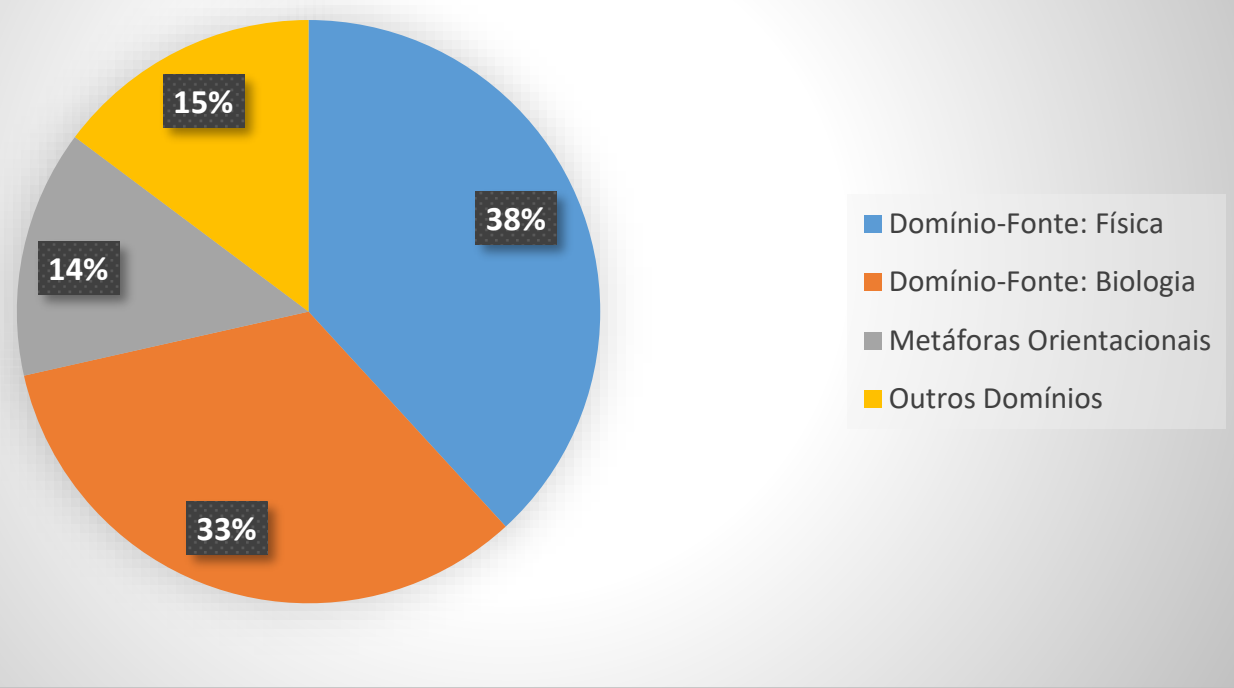

As porcentagens apresentadas acima permitem-nos afirmar que as metáforas da Economia são sobremaneira científicas, pois são relacionadas a conceitos cujos domíniosfonte são oriundos da Física (38\%) e da Biologia (33\%), assumindo 71\% do total dos 860 termos metafóricos que foram analisados nos capítulos que tratam sobre essas ciências. Os demais percentuais que perfazem o total de $29 \%$ podem ser divididos em $15 \%$ no que se refere a conceitos mais cotidianos (outros domínios) e 14\% são representados pelas metáforas orientacionais relacionadas a experiências corpóreas e culturais. 


\section{BREVE CONSIDERAÇÃO SOBRE AS CARACTERÍSTICAS MORFOLÓGICAS DAS METÁFORAS DA ECONOMIA}

Os vocábulos especializados inclinam-se a apresentar características da formação de palavras muito próximas às do léxico geral de acordo com análise realizada por Lerat (1997), por exemplo. São processos relativos a derivações, composições sintagmáticas e também empréstimos linguísticos em terminologias. Neste corpus estudado, uma dessas formações destaca-se por sua produtividade: esse é o caso das composições sintagmáticas, cuja maioria é de caráter nominal.

Segundo Alves (2002, p 54), a formação sintagmática ocorre com muita frequência nos vocabulários técnicos, resultando, nessas situações de uma indecisão em relação à designação de uma nova noção. Para a mesma autora (2002, p. 50), a composição sintagmática é processada quando membros que compõem um elemento frasal aparecem em uma íntima relação sintática, tanto morfológica quanto semântica, de maneira que constituem uma única unidade léxica. É o caso de unidades terminológicas localizadas na compilação de textos estudados nesta tese, como bolha de capital fictício, cujo significado do termo não pode ser depreendido isoladamente com base em cada um dos elementos que compõem o sintagma, mas só pode ser compreendido pelo seu conjunto. Esse tipo de formação é muito representativo neste corpus pesquisado, ocupando $97 \%$ dos termos prospectados. Sendo assim, dentre os processos de formação de palavras ocorrentes nos textos compilados, faremos mais adiante também a análise das composições ou formações sintagmáticas metafóricas.

De acordo com Kocourek (1991, p. 169), as formações sintagmáticas com metáfora ocorrem também em outros tipos de corpora terminológicos. No caso da Economia, não seria diferente, conforme demonstram os dados estatísticos apresentados no parágrafo anterior. Neste corpus analisado, observamos que as metáforas assumem majoritariamente a posição de determinado. Assumindo esse tipo de arranjo, as composições sintagmáticas nos levam a inferir na maior parte das vezes que as metáforas nas formações sintagmáticas da Economia facilitam, com uma certa frequência, uma generalização do termo, apresentando algum conceito "novo". Em ataque especulativo, por exemplo, observamos que o primeiro elemento (determinado) é metafórico, e o elemento determinante, referente ao tipo de ataque, é o que estabelece um caráter específico ao sintagma, pois o adjetivo especulativo refere-se a um dos aspectos da 
economia capitalista, que consiste em fazer operações financeiras com o objetivo de se obter lucros significativos.

As metáforas na posição de determinante podem ser ilustradas por algumas unidades terminológicas, tais como economia aberta, economia fechada, economia madura, entre outras. Nesses exemplos, quando assume esse tipo de posição, a metáfora constitui-se em um processo em que ocorre uma predicação fazendo referência a propriedades específicas e relevantes dessa área de conhecimento, permitindo a inferência de traços que remetem ao significado do sintagma; no caso de economia madura, a metáfora "madura" caracteriza um tipo de Economia que chegou a um nível de evolução satisfatório, ao contrário, por exemplo, de uma economia semi-industrializada. A seguir, a unidade metafórica extraída de um de seus contextos dos corpora coletados:

\footnotetext{
No artigo, 'Growth, Degrowth and Climate: A Scenario Analysis', Victor (2012) utiliza o termo decrescimento para explorar cenários de redução do PIB per capita no Canadá. No entanto, para caracterizar o processo de redução do fluxo de throughput das economias desenvolvidas, Victor (2011: 19) sugere que utilizemos a expressão 'transição para uma <economia madura>'. Segundo o autor, 'a economia do crescimento é imatura como um adolescente que tem surtos de crescimento. Quando atinge a idade adulta, não se espera que continue crescendo, há certa estabilidade'. (SAES, B. M. Macroeconomia ecológica: O desenvolvimento de abordagens e modelos a partir da economia ecológica, 2013)
}

As formações sintagmáticas metafóricas que se mostraram mais produtivas para a formação da terminologia da Economia, de um modo geral, podem ser reunidas nos seguintes agrupamentos de acordo com as frequências em destaque:

\section{Frequência 1}

S Met + Adj (substantivo metafórico + adjetivo): acelerador financeiro, alavancagem bancária, âncora fiscal, bolha especulativa, entre outras.

\section{Frequência 2}

S Met + SP (substantivo metafórico + sintagma preposicional): bolha de preços, choque de juros, crise de hipotecas, motor da economia, entre outras. 
S Met + SP + Adj (substantivo metafórico + sintagma preposicional + adjetivo): fluxo de capitais estrangeiros, liquidez do mercado cambial, volatilidade do câmbio nominal, choque de política monetária, entre outras.

\section{Frequência 3}

S + SP Met (substantivo + sintagma preposicional metafórico): vetor de choques, teoria dos jogos, entre outras.

\section{Frequência 4}

S Met + SP Met (substantivo metafórico + sintagma preposicional metafórico): colapso da bolha, colchão da liquidez, fundo do poço, entre outras.

\section{Frequência 5}

S Met + SP Met + Adj (substantivo metafórico + sintagma preposicional metafórico + adjetivo): colapso da bolha imobiliária, motor do crescimento econômico, entre outras.

\section{Outras frequências}

S Met + Sigla (substantivo metafórico + sigla): crescimento Pib, fundo Itcm, crise dos EBEs, entre outras.

S Met + Estrangeirismo (substantivo metafórico + estrangeirismo): fundos private, fundos hedge, entre outras.

S Met + SP [estrangeirismo] (substantivo metafórico + sintagma preposicional seguido de estrangeirismo) : fundos de default, fundos de private, fundos de hedge 
Adj + S Met + Adj (adjetivo + substantivo metafórico + adjetivo): livre flutuação cambial

Por último, pudemos observar algumas raras formações sintagmáticas em que ocorre, no elemento determinado, uma derivação prefixal. Em macroeconomia aberta, o prefixo macro acrescenta ao significado de Economia o sentido da grandeza, cuja análise econômica refere-se ao seu sistema global desconsiderando-se as suas particularidades. A analogia com a metáfora do contêiner recai no adjetivo "aberta", referindo-se a um tipo de Economia que permite o fluxo livre de entrada e saída de bens, serviços, capital e pessoas.

A seguir, a título de exemplo desse tipo de formação, apresentamos um dos contextos em que o termo é localizado no material compilado:

O efeito denominado hysteresis tem sua origem na física, e tem sido constantemente aplicado na economia com a finalidade de se explicar mudanças no nível de equilíbrio externo causadas por choques na taxa de câmbio real da economia. Tal conceito, explorado inicialmente em <macroeconomia aberta> por Baldwin (1988, 1989, 1990), Baldwin e Krugman (1989), Dixit (1989, 1992) e Dixit e Pindyck (1994), considera a existência de custos de entrada em novos mercados que não podem ser recuperados posteriormente, ou, em outras palavras, sunk costs no comércio internacional. (TELES, W. K. Choques cambiais, política monetária e equilíbrio externo da economia em um ambiente de hysteresis, 2005)

Derivação prefixal + Adj Met (adjetivo metafórico): macroeconomia aberta.

\section{Composições (justaposição de elementos):}

Além das formações sintagmáticas, encontramos neste corpus estudado, ainda que com baixa produtividade, composições em que há justaposição de elementos. Verifiquemos alguns desses casos a seguir:

Substantivo + S Met (substantivo + substantivo metafórico): moeda-chave, divisachave, efeito-farol, efeito-contágio, entre outras.

Com maior produtividade em relação às composições justapostas, ocorre o sistema misto entre composições por justaposição + sintagma preposicional e substantivos metafóricos + adjetivos compostos. Adiante apresentamos alguns exemplos: 
Composição (substantivo metafórico + substantivo) + SP: elasticidade-juros de demanda, elasticidade-preço de oferta, entre outras.

S Met (substantivo metafórico) + Composição (adjetivo composto): crise fiscalfinanceira, entre outras.

S Met (substantivo metafórico) + Composição (adjetivo composto): fundo verdeamarelo, ${ }^{80}$ entre outras.

As formações sintagmáticas metafóricas da Economia são abundantemente endocêntricas, uma vez que o referente relativo aparece no elemento determinado ou determinante do termo em um dos seus elementos (SANDMANN, 1992, p. 43). ${ }^{81}$ Esse é o caso, por exemplo, de economia fechada, termo que denomina uma economia típica de uma região isolada onde não há nem importação nem exportação de produtos. No exemplo citado, o referente relativo à área da Economia ocorre no primeiro elemento, e, a metáfora, no segundo:

Segundo Davidson (1994, p. 226-228) os ciclos dos mercados financeiros e de comércio internacionais caminham pari passu. $\mathrm{Na}$ <economia fechada> a ampliação do nível de atividade requer aumentos na oferta de moeda devido à intensificação do finance que antecede o investimento. Na economia mundial, onde também prevalecem incerteza, defasagens temporais e a ausência de perfeita coordenação de fluxos de caixa associados ao comércio entre nações, o aumento da liquidez internacional é pré-condição para a expansão do comércio, ainda que este ocorra no âmbito do equilíbrio comercial das nações envolvidas. (RESENDE, M. F. da C. O padrão dos ciclos da economia brasileira: 1947-2003, 2005)

A maioria das formações sintagmáticas da área de especialidade estudada é de estrutura substantivo + adjetivo $(s+a d j)$, seguida de substantivo + sintagma preposicionado $(\mathrm{s}+\mathrm{SP}$ ). Tanto nas estruturas $\mathrm{s}+\operatorname{adj}($ substantivo + adjetivo) quanto nas

${ }^{80}$ Consideramos a composição adjetival "verde-amarela" metonímica, pois essas cores se referem às principais colorações da bandeira brasileira representando o símbolo pelo simbolizado, no caso o Brasil, cujo "ponto de referência (PR) é "verde-amarelo" e a zona ativa (ZA) é "nação". Esse modelo de análise de metonímias cognitivas é proposto por Langacker (1984, 1993, 1999, apud Silva, 2003, p. 46).

81 Para Sandmann, as "composições" metafóricas podem ser categorizadas como endocêntricas e exocêntricas. Como exemplos de endocêntricas, ele cita as formações peixe-espada e trem-bala, pois apenas "espada" e "bala" são empregadas metaforicamente, peixe-espada continua sendo "peixe" e trem bala continua sendo "trem", porém no composto perna-de-moça não se trata mais de uma "perna", mas de um "peixe". A extensão do significado é para fora é para fora da combinação, por isso é um composto exocêntrico. 
formações $\mathrm{s}+\mathrm{SP}$ (substantivo + sintagma preposicionado), a metáfora aparece, com frequência, na posição de elemento determinado, e, com menor produtividade, na última posição. ${ }^{82}$ De acordo com Alves (1999, p.74), muitas formações sintagmáticas que se iniciam por um substantivo metafórico tendem a se expandir à direita. Ela afirma que esse fenômeno é bastante comum nas línguas de especialidade, pois representa um conceito correspondente a uma nova invenção, uma nova tecnologia, uma especialização da noção expressa pelo termo genérico.

Encontramos com baixa frequência as formações constituídas por metáfora + metáfora, tratando-se de casos em que o segundo elemento é antecipado por uma preposição, apresentando a seguinte formação: S Met + SP Met (substantivo metafórico + sintagma preposicional metafórico), como colapso da bolha, em que bolha determina com mais propriedade o termo, uma vez que se trata de um processo em que um ativo supervalorizado vai sofrer uma queda brusca de seus preços, gerando o fenômeno do "estouro da bolha", que causa prejuízo aos seus investidores. Possivelmente esse tipo de formação é menos frequente pelo fato de essa estrutura de estrutura semântica e morfológica não cumprir a função esclarecedora da metáfora, facilitando um tipo de compreensão dessa área de conhecimento - porquanto, nessas formações não há nenhum termo cujo referente seja relativo à área de Economia. Com baixíssima produtividade, há a formação metáfora + metonímia exemplificada por fundo verde-amarelo, na qual fundo representa o processo metafórico, e verde-amarelo, o metonímico, uma vez que essas cores se referem às principais cores da bandeira brasileira, representando o símbolo pelo simbolizado. A seguir, o termo contextualizado:

\footnotetext{
Com os fundos setoriais, a recuperação da capacidade financeira da Finep e o crescente empenho do BNDES em apoiar P\&D, ademais da Lei do Bem em 2005, perde paulatinamente esse papel, que passa a ser residual, mesmo no âmbito das renúncias fiscais. 327 funding das operações reembolsáveis da Finep (além, naturalmente, da parcela do "Fundo Verde-Amarelo" que é destinada à equalização de taxas de juros em essas operações). Como, mais especificamente, os recursos dos FS em sentido estrito são executados? Como visto, eles podem ter sua origem remontada ao processo de privatização, ao ajuste fiscal após o colapso do câmbio fixo (a o pacote 51, de fato), à Constituinte de 1988 (e ao PL do deputado Florestan Fernandes, bem como à lei paulista de destinação de $1 \%$ da arrecadação estadual para a IES e ICTs
}

\footnotetext{
${ }^{82} \mathbf{S}+\mathbf{S P}+$ Adj Met: taxas de juros flutuantes, regime de câmbio flutuante.

S + Adj + SP Met: índice geral de alavancagem
} 
públicas paulistas) e aos Pactis. (GIESTEIRA, L. F. O desenvolvimento após o desenvolvimentismo: origens, resultados e limitações da política brasileira de inovação tecnológica (1999-2008), 2010)

Também verificamos que muitas formações sintagmáticas do tipo substantivo metafórico + adjetivo tendem a expandir-se à direita, como em tigre asiático, termo estendido para tigres de primeira geração e tigres de segunda geração. Nesses exemplos, há ampliação, mas também redução do sintagma tigres asiáticos de primeira geração e de tigres asiáticos de segunda geração para tigres de primeira geração e de segunda geração, ocorrendo o apagamento do adjetivo asiático a fim de atender provavelmente ao princípio da economia linguística. ${ }^{83}$

Com um número inferior de ocorrências, localizamos algumas composições por justaposição (moeda-chave, entre outras) e siglação na posição de determinante acompanhado de um determinado metafórico (como, por exemplo, fundo ITCM), e outras também com algumas palavras de origem inglesa (como fundo hedge, em que a segunda unidade, constitui um estrangeirismo). ${ }^{84}$ No tocante aos estrangeirismos, podemos afirmar que muitos termos da Economia são decalques (traduções literais de um termo). Kocourek (1991, p. 91) afirma que esse procedimento linguístico é bastante comum no processo de denominação de um conceito, posto que existe um determinado paralelismo entre muitas línguas. ${ }^{85}$ Porém, mesmo que esse fenômeno ocorra nesse tipo de terminologia, as formações mais produtivas deste corpus são as vernáculas, haja vista o volume de termos autóctones que foram levantados para este estudo. Desse modo, ao demonstrarem sua capacidade de expressar conhecimentos dessa especialidade por meio de seu repertório lexical, os termos da Economia no português brasileiro evidenciam o grau de desenvolvimento dessa comunidade linguística por meio de sua constituição morfossintática.

Por último, constatamos através dos dados arrazoados para esta pesquisa que as formações metafóricas constituídas por lexia simples apresentam baixa

\footnotetext{
83 Termo cunhado por André Martinet em 1955.

${ }^{84}$ Ainda que anglicismos tenham sido descartados no momento do uso da ferramenta eletrônica para a prospecção das unidades que fariam parte das planilhas geradas para a seleção de termos, alguns deles despontaram nesta fase devido ao fato de assumirem a função de determinante junto a um elemento determinado vernáculo metafórico. Assim, resolvemos mantê-los nesta análise nas situações em que eram empregados junto a uma metáfora do tipo fundo private ou a sua variante fundo de private, pois julgamos que eles poderiam esclarecer algum tipo de informação de ordem morfológica e semântica sobre esse tipo de hibrismo.

${ }^{85}$ Devido à relevância do tema, iremos nos deter nesse assunto na próxima seção (7.1).
} 
representatividade em nosso corpus analisado (cf. com outros trabalhos como o de Oliveira, 2011), além de baixíssima produtividade de bases presas derivadas. Nas terminologias, as lexias simples ocorrem com pouca frequência, muito provavelmente pelo fato de elas não descreverem de forma mais específica um conceito, tal como uma unidade terminológica formada por substantivo + adjetivo.

Perscrutando as constituições morfológicas, compreendemos que os conceitos especializados da Economia fazem progredir sua teoria, uma área de especialidade que tem como parâmetro processos morfológicos mais amplos. Assim, através das análises realizadas em relação às lexias complexas, conseguimos notar que no vocabulário da Economia são muito frequentes os processos de "especialização semântica", sobretudo no que se refere às formações de sintagmas terminológicos de caráter metafórico. A metáfora cumpre, nesses casos, a função denominativa da linguagem da Economia, enriquecendo a linguagem da Economia em seu processo de especialização semântica (cf. ENTERRÍA, 1998, p. 76).

A análise realizada, em síntese, nos leva a concluir que cada sistema de classificação determina o tipo de processo de formação de palavras necessário para uma comunicação eficiente, porquanto cada especialidade apresenta necessidades particulares (SAGER, 1999, p. 93-4). No caso da Economia, confirmamos que eles são, sobretudo, processos autóctones de base sintagmática.

\subsection{Os decalques da Economia}

Em nossa dissertação de mestrado, defendida em 2007, havíamos considerado que um grande número de termos oriundos da mídia impressa da Economia é decalcado do inglês. Nesta tese de doutorado, elegemos esse assunto como um dos tópicos a ser discutido, a fim de demonstrar e de analisar como algumas unidades especializadas da Economia, no caso de cunho metafórico, são formadas também por meio desse processo.

Esse ponto de vista também é confirmado por outros autores, tais como Gomez de Enterría (1998, p. 84). A pesquisadora defende a ideia de que a maioria dos termos metafóricos da Economia são decalques do inglês e tal fato se comprova pelo fato de observamos, por meio de seus equivalentes em inglês, que esses termos são traduzidos literalmente. Ainda que alguns profissionais da área de tradução não concordem com esse fato, conforme entrevista realizada a ser comentada mais à frente, também notamos em 
nosso corpus de estudo que muitos termos metafóricos são decalques do inglês. Isso se comprova à medida que, ao consultarmos alguns dicionários da área, tais como o Business dictionary - Dicionário de termos de negócios: inglês-português, português-inglês (Migliavacca), o Dicionário de termos de negócios: português-inglês, EnglishPortuguese (Pinho) e o Dicionário de termos financeiros e bancários (Biderman), verificamos que grande parcela dos termos da Economia em português brasileiro oriundos do inglês são termos traduzidos literalmente. É o caso, por exemplo, de alavancagem (leverage), que é uma redução das formações alavancagem financeira, alavancagem bancária, alavancagem de crédito, entre outras.

De acordo com Alves (2002, p. 79), do ponto de vista de sua formação, o decalque é um "modo de integração de uma formação estrangeira a outro sistema linguístico". Esse tipo de processo de formação "lexical" é de difícil reconhecimento, uma vez que ele consiste na versão "literal" de uma palavra de origem estrangeira para o idioma receptor. Exemplo: alta tecnologia é um decalque do inglês high technology. A mesma autora também afirma que o vocábulo foi adaptado por meio desse processo, concorrendo também com a palavra que lhe deu origem; ela cita o caso de alta tecnologia, que "concorre" com high tecnology. Nesses processos, pode haver ainda alteração da ordem desses termos no processo de integração dos estrangeirismos, tais como loja de departamento, originário de department store. A seguir, um exemplo citado de contextos extraídos de corpus da imprensa brasileira em Alves (2002, p. 80), no qual alta tecnologia é apresentado como um decalque de high tecnology: "A < alta tecnologia> fica por conta da produção, caríssima, enquanto o script e seu valor mental situam-se na Idade da Pedra (IE, 25-07-87: 31, c. 1)".

Outros pesquisadores, como Biderman (1978, p. 164), também consideram o decalque como um tipo de estrangeirismo, ou seja, uma versão literal do lexema modelo da língua originária, tratando-se de uma adaptação do estrangeirismo em relação à fonética e à ortografia do português brasileiro. Ela critica decalques, traduções e incorporações que não são feitos adequadamente pelo fato de seus introdutores com frequência conhecerem pouco a estrutura lexical da língua e sua expressividade, fazendo com que eles sejam claudicantes e desfigurados, inclusive, nos meios técnicos e científicos.

Vejamos os comentários a respeito desse assunto feitos pela autora ao avaliar negativamente algumas classes profissionais em relação ao uso de decalques por não levarem em consideração nosso vernáculo com seus próprios processos de formação de 
palavras e acusando o uso do inglês como o principal elemento desfigurador da nossa língua:

\begin{abstract}
Nos meios técnicos e científicos, infelizmente, isso se dá com alta frequência. A título de exemplo: decodificação (em vez de descodificação), decodificador, apagar (em vez de omitir), apagamento (em vez de omissão). Aliás os comunicadores, os técnicos em computação e os linguistas, para não falar de outras classes profissionais, têm primado pelo desrespeito ao gênio da língua portuguesa e aos seus processos próprios de formação de palavras. E o inglês está sendo o terrível verdugo que vai desfigurando cada vez mais a nossa língua! (BIDERMAN, 1978, p. 164).
\end{abstract}

Entre os gramáticos, Bechara (2004, p. 599) divide os estrangeirismos nos tipos a seguir: os que são assimilados pela língua, cujo reconhecimento só é possível para quem conhece sua história (por exemplo, a palavra guerra, oriunda do alemão), os que se apresentam de forma estrangeira (maillot, ballet, feedback etc.) e os que se deixam passar por vocábulos vernáculos (maiô, abajur, tíquete etc.). Apesar de não fazer menção à palavra decalque, entendemos que o autor desaprova esse tipo de adaptação, pois nesses dois últimos exemplos ele usa a expressão "os que facilmente mostram não ser prata da casa". Por outro lado, Bechara afirma (2004, p. 600) que esses empréstimos não sofrem mais as mesmas críticas que outrora, exceto os empréstimos lexicais desnecessários e sem muita repercussão em outras línguas de cultura do mundo.

Ao se confirmar essa consideração realizada por Alves (2002, p. 79), de que reconhecer um decalque nem sempre é tão fácil, pois exige do leitor um conhecimento bem estreito dos idiomas e culturas em contraste, devemos levar em consideração, do ponto de vista etimológico, o quanto às vezes torna-se complicado identificar um vocábulo decalcado, conforme demonstra Viaro (2014, p. 280) por meio da palavra pintarroxo:

\footnotetext{
Mais complexo é port pintarroxo, em que o primeiro elemento se transformou por analogia: petti-> *peti>pinta- $\prec$ pintassilgo. O roxo do vocábulo português é um arcaísmo hoje, pois denotava tons de vermelho na sincronia pretérita em que a palavra foi introduzida (como esp rojo < lat russeum "vermelho escuro" § 3). O étimo, como dito, não impede que o falante, devido à analogia, associe o primeiro elemento de pintarroxo ao verbo pintar e crie a partir dessa convicção, etimologias fantasiosas com alguma repercussão (por exemplo, histórias infantis, em que o pássaro seja um pintor que só use roxo nas suas telas etc., § 3.2.9)
}

Esse fenômeno linguístico, ainda de acordo com Viaro (2014, p. 277), já era adotado pelos romanos; eles realizavam o decalque para evitar empréstimos do grego e 
essa prática também foi adotada, por exemplo, no inglês e no alemão. Exemplos: gr pantokrátor "todo poderoso" $\geq$ lat omnipotens $\geq$ allmighty $=$ alem allmächtig.

Nota-se aqui também que um decalque passa a se popularizar, ou seja, começa a ser usado na linguagem comum, quando as palavras decalcadas aparecem nos discursos religiosos, científicos, pedagógicos, jornalísticos e, sobretudo, na atualidade, por meio da web. No entanto, apesar de o decalque ser um procedimento de tradução adotado para algumas palavras de origem estrangeira, e em alguns casos essas passarem a fazer parte da linguagem comum, nem sempre eles são incentivados (VIARO, 2014, p. 277).

No que se refere ao nosso corpus de estudo, podemos observar que há muitas semelhanças entre os termos metafóricos do inglês e do português. Em estudo comparativo entre o inglês e o espanhol realizado por Charteris-Black e Ennis (2001, p. 5), os autores afirmam que ambas as línguas apresentam um campo conceitual metafórico bastante semelhante, de forma que podemos deduzir que tal fenômeno ocorre pelo fato de haver a presença de palavras de origem latina, um ancestral linguístico de ambos os idiomas. Os pesquisadores também consideram que cognatos do inglês e do espanhol são comuns em várias áreas técnicas. Cerca de $30 \%$ do léxico dos termos técnicos do espanhol são cognatos do inglês, o que facilita o reconhecimento dos termos por parte de quem lê e escreve em uma língua estrangeira.

A hipótese exposta acima sobre a dedução de que os termos metafóricos apresentam semelhanças pelo fato de terem um mesmo ancestral linguístico, ainda que possa ser comprovada, não leva em consideração o fato de que existe uma economia globalizada, e de que, portanto, nesse contexto histórico, os termos da Economia são oriundos da língua inglesa, idioma de destaque nas relações comerciais de ordem internacional.

Para Charteris-Black e Ennis (2001, p. 20), vários jornalistas que escrevem em língua espanhola fazem uso de empréstimos linguísticos do inglês ao escreverem textos sobre a área de negócios, influenciando, dessa forma, seu estilo de escolha lexical dada a importância do inglês no mundo da Economia, uma vez que esses empréstimos referemse aos mesmos sistemas econômicos compartilhados. Esses empréstimos não ocorrem somente no espanhol, também acontecem em português, uma vez que os termos da Economia do Português Brasileiro frequentemente são decalcados do inglês, e, não raramente, os jornalistas fazem uso de anglicismos. Esse recurso, porém, não parece ser usado somente pela mídia, os economistas também usam esses termos decalcados ao 
falarem sobre essa área de conhecimento, pois eles são recorrentes em nosso corpus, conforme tabelas que serão apresentadas mais à frente.

Do ponto de vista do seu processo de formação de palavras, é muito comum ocorrerem decalques em formações sintagmáticas nas linguagens especializadas. Conforme Alves (2008, p. 13), o decalque costuma refletir, nessas situações, uma neologia criada por tradutores, a neologia tradutiva. Esse tipo de decalque pode ser observado, de acordo com a autora, nas formações sintagmáticas visivelmente decalcadas:

\section{- free market, free floating Exchange}

Em editorial, $O$ Estado de S.Paulo tocou no mesmo ponto quando sustentou que 'o <livre mercado> e o <livre comércio> costumam ser mais elogiados que praticados' e que 'a meta do governo Clinton é derrubar tarifas de seus parceiros'. (FSP, 08-10-97)

Alguns tradutores afirmam, no entanto, que o decalque não é um procedimento linguístico adotado por eles. Conforme Labate (2007, p. 47), o uso de decalque não é muito frequente nas traduções. Ele diz que esse recurso é "objeto de restrições e de hostilidade", porém, ele não explica a origem dessa informação em seu estudo. Para o tradutor, o empréstimo linguístico (estrangeirismo) é mais frequente do que o decalque.

Em entrevista concedida pelo professor da Universidade Federal de Pernambuco (UFPE) Yuri Amorim Caribé ${ }^{86}$ para este trabalho, esse pesquisador afirma que a tradução de textos científicos, denominada como tradução técnica ou científica, é beneficiada pelos programas de memória de tradução e uso dos glossários terminológicos bilíngues. Para ele, não existe a tradução do termo técnico, mas "a pesquisa" do termo, a qual apresenta características específicas na língua de chegada. Caribé afirma que o decalque - ou seja, a "tradução literal" - não existe em traduções técnicas (tal procedimento pode ser considerado erro de tradução) e que, no final do processo tradutório desse tipo de texto, é realizada uma validação por parte de um leitor bilíngue especialista na área de conhecimento.

Nessa mesma entrevista, perguntamos se o termo tigre asiático (Asian tiger), usado na Economia, é um decalque. Ele afirmou que, no caso dessa unidade terminológica, se alguém já o usou pela primeira vez e ela passou a circular

\footnotetext{
${ }^{86}$ Yuri Caribé trabalha também como tradutor e intérprete.
} 
mundialmente, então essa tradução acaba sendo aceita e utilizada. Para ele, um termo que circula com muitas entradas, cuja frequência é aferida por meio do Google, não é um decalque; um termo "equivocado" tem poucas entradas. Por último, Caribé considera que o "batismo" de decalque pertence a uma corrente clássica da tradução; porém, na atualidade, o termo é pouco utilizado. Nessa perspectiva, a tradução técnica apresenta relações mais estreitas com a linguística do que com os estudos teóricos da tradução. Portanto, o decalque é um procedimento equivocado na atividade tradutória.

Para Gomes (2013, p. 15), ao se traduzir um texto especializado da União Europeia, alguns requisitos adicionais devem ser atendidos, tais como normas de estandardização internacional da linguagem especializada. Esse autor afirma que, para a tradução de termos econômico-financeiros, o tradutor recorre frequentemente a fontes de terminologia bilíngue e/ou multilíngue, de modo a escolher os equivalentes de tradução apropriados, atendendo aos contextos, para confirmar que a escolha do termo foi a correta. Normalmente, quando esse equivalente não é encontrado, opta-se por uma tradução descritiva (explicativa) ou mantém-se o termo original.

Exposta a ideia de que no campo da tradução o decalque não deve ser praticado, devemos ainda considerar a hipótese de que, nesse processo, é mais fácil optar pela tradução literal do que encontrar um equivalente no idioma a ser traduzido, cujo conceito represente a cultura na língua de chegada. De qualquer forma, mesmo com todas as críticas feitas ao decalque, é importante sublinhar que esse modo de integração estrangeira não ocorre somente na linguagem jornalística mas também na linguagem científica, de forma que muitos desses conceitos fazem parte de nosso cotidiano baseados em nossa experiência corpórea, natural e cultural, tendendo a uma certa universalização. Verifiquemos por exemplo, a seguir, algumas metáforas decalcadas empregadas em nosso corpus de estudo reveladoras desse caráter "conceptualizador", de acordo com alguns campos cognitivos: $:^{87}$

\footnotetext{
${ }^{87}$ A equivalência dos termos da Economia do português para o inglês foram consultadas nas seguintes bases: Business dictionary - Dicionário de termos de negócios: inglês-português, português-inglês (Migliavacca), o Dicionário de termos de negócios: português-inglês, English-Portuguese (Pinho) e o Dicionário de termos financeiros e bancários (Biderman), além de fontes de pesquisa eletrônicas da área de economia e de finanças.
} 


\section{ECONOMIA É GUERRA}

TERMOS DECALCADOS - PORTUGUÊS

ataque especulativo

guerra fiscal
TERMOS - INGLÊS

speculative attacks

tax war

ECONOMIA É FÍSICA (E FENÔMENOS AFINS TAIS COMO: ECONOMIA É CORRENTE EM MOVIMENTO, UM ESTADO GASOSO, ELASTICIDADE, NÁUTICA, ENTRE OUTROS)

TERMOS DECALCADOS - PORTUGUÊS

aceleração da inflação

alavancagem

alavancagem financeira

calibragem

flutuação

fluxo de caixa

fluxo de capital

elasticidade da oferta

balanço líquido

volatilidade cambial

flutuação cambial

fluxo cambial

âncora cambial

bolha especulativa

bolha financeira

bolha da internet

bolha de ações

bolha de preços

colapso da bolha

bolha imobiliária
TERMOS - INGLÊS

acceleration of inflation

leverage

financial leverage

calibration

fluctuation

cash flow

capital flow

elasticity supply

net balance

exchange rate volatility

exchange rate fluctuation

exchange rate flow

currency anchor

speculative bubble

financial bubble

internet bubble

stock bubble

price bubble

bubble colapse

housing bubble 
ECONOMIA É EQUILÍBRIO

balanço líquido

net balance

balanço do FED

Fed's balance sheet

ECONOMIA É AÇÃO VIOLENTA, COLISÃO

choque heterodoxo

heterodox shock

choque de petróleo

oil shock

\section{ECONOMIA É UM ORGANISMO}

crescimento econômico

economic growth

ECONOMIA É SAÚDE

colapso da crise imobiliária

colapse of the housing bubble

crise econômica

economic crisis

crise financeira

financial crisis

pânico financeiro

financial panic

ECONOMIA É JOGO

jogo financeiro

financial game

ECONOMIA É ESTRATAGEMA

armadilha de liquidez

liquidity trap

\section{ECONOMIA É LIMPEZA}

lavagem de dinheiro

money laundering 
tigre asiático

Asian Tiger

Muitos outros termos metafóricos poderiam ser incluídos no mapeamento acima exposto, uma vez que, ao pesquisarmos os termos em português com seus equivalentes em inglês, temos a "impressão" de que existe uma tradução literal dos termos. Contudo, tendo em mente que nosso trabalho não é o de fazer uma pesquisa específica sobre decalques, mas sim, de estudar o processamento das metáforas da Economia, decidimos apresentar apenas alguns de seus exemplos. ${ }^{88}$

Alguns desses decalques metafóricos podem ser considerados como "malformados" - termos "maltraduzidos" - . Alguns especialistas citam o caso de tigre asiático, decalque de Asian tiger, conceito que para nós, brasileiros pode não fazer muito sentido, visto que na América do Sul existem outros tipos de felinos, mas não há tigres. Contudo, por conhecimento enciclopédico, podemos compreender o conceito que se pode depreender de tal formação, uma vez que tigre é um animal poderoso que habita o continente asiático, cujo significado em Economia diz respeito aos países que se destacam no cenário econômico da Ásia. Portanto, consideramos que o termo metafórico tigre asiático não é um decalque mal-formado, visto que compreendemos perfeitamente suas projeções cognitivas.

Por último, queremos considerar neste trabalho que não cabe ir à defesa ou não do uso do decalque em terminologia, uma vez que, do ponto de vista linguístico, não há nenhum problema na adoção desse mecanismo, cuja prática, conforme mencionado por Viaro (2014), já era adotada desde a Roma Antiga. Para Faraco (2004, p. 98-9), os estrangeirismos se disfarçam de vernáculos, cujo uso exagerado desfigura o texto; contudo, tal uso leva-nos a refletir que o maior mal não consiste em seu emprego, mas sim, em não acompanhar o desenvolvimento internacional do léxico adotado.

\footnotetext{
${ }^{88}$ Outro tipo de metáfora decalcada de uso bastante recorrente em nosso corpus de estudo é proveniente do termo fundo com mais de 103 ocorrências (lexias simples e complexas). Trata-se de uma metáfora orientacional, correspondendo a formações sintagmáticas com mais de dois formantes a exemplo de fundo comum, fundo de investimento, fundo de aplicação financeira, correspondendo a mais de 64 termos. De acordo com o dicionário on-line Etymology dicionary (htpps://www.etymonline.com), a origem do termo fundo, do inglês fund, origina-se do francês fond (1670), que por sua vez é oriundo do latim fundus, cujo significado de conjunto de recursos monetários empregados como reserva ou para cobrir despesas extraordinárias surge em inglês em 1690 (cf. SANDRONI, 2005, p. 256).
} 
Dessa forma, acredita-se que as metáforas decalcadas do nosso corpus de análise tendem a uma certa universalização, pois revelam uma visão de mundo bastante próxima entre as culturas em contraste, demonstrando essa faceta do decalque, que é a de introduzir um novo elemento linguístico ao repertório lexical de um idioma por meio do contato entre culturas e idiomas. Esses decalques, bem-adaptados ou não aos nossos valores culturais, atendem antes de tudo a um caráter universalizante e estão respaldados no conhecimento enciclopédico, pois, de outro modo, não seriam bem compreendidos e interpretados. Além do mais, muitos dos livros didáticos de Economia usados em países não anglófonos são traduções de originais em inglês ${ }^{89}$, fato esse que teve uma forte influência no estabelecimento das metáforas conceituais semelhantes nesses idiomas.

${ }^{89}$ Devemos levar em consideração também que inúmeras traduções realizadas dos termos econômicos são realizadas pelos próprios especialistas e não por tradutores. 


\section{PARTE IV}

\section{CONSIDERAÇÕES FINAIS}

A realização desta pesquisa em nível de doutoramento pretendeu contribuir parcialmente com as pesquisas que versam sobre as metáforas terminológicas, mais especificamente, em relação àquelas que ocorrem no discurso científico da Economia.

Os dados que foram coletados de textos acadêmicos, processados, tabulados e organizados em campos conceituais permitiram-nos concluir que as metáforas da Economia do português brasileiro contribuem para a conformação de uma terminologia científica, atendendo aos fatores designativos exigidos pelas linguagens de especialidade. Dessa forma, as metáforas da especialização econômica possibilitam a apreensão de um conhecimento "complexo", favorecendo por meio das analogias um suporte imaginativo de algo já conhecido em nosso cotidiano.

Quando pensamos na precisão designativa dos termos metafóricos da Economia, podemos apresentar como exemplo a metáfora da "bolha". No termo bolha de ativos financeiros e imobiliários, a metáfora "bolha" designa de forma precisa todo um processo que exigiria provavelmente muitas palavras para explicar a seguinte situação: valores de um determinado ativo já não se sustentam no mercado financeiro e imobiliário. A ideia é a de que uma "bolha" ocorre quando um "investimento" tem seu valor superestimado por um dado período de tempo, e, em algum momento, acabará sendo desvalorizado, já que seus valores não se sustentam. Logo, a analogia estabelecida entre "bolha" e a "supervalorização/desvalorização" de um ativo, apresenta como traço conceptual um fenômeno "físico", que é o da dissipação, um acontecimento de "insustentação" na área financeira.

Para se chegar a esse tipo de denominação, o especialista processou o seu pensamento por meio de um sistema conceitual, estabelecendo projeções analógicas através de uma imagem da "dissipação", apoiando-se nesse tipo de metáfora fundamentada, sobretudo, em uma conceptualização metafórica que associa, em ciência, a compreensão por conceitos ou por sensações. O especialista, ao evocar essa metáfora, construiu um conhecimento tendo por base uma determinada visão de mundo, e uma adequação dela, coligada à sua própria percepção de experiências cotidianas. O especialista necessitou então de um conceito físico, que é o da dissipação, e de uma imagem visual para descrever um conceito baseado em experiências corporais e sensoriais para denominar o objeto de sua descrição. 
Podemos sintetizar o processo acima descrito pelas ideias apresentadas por Gibbs (1994, apud Oliveira, 2011, p. 164), ${ }^{90}$ ao afirmar que as metáforas são campos férteis para as ciências, pois elas expressam ideias complexas, que dificilmente seriam explicadas com valor literal. Elas compactuam o discurso e capturam a intensidade de nossas experiências fenomenológicas, invocando imagens mentais sobre determinados acontecimentos e evidenciando sua potencialidade epistemológica. Desse modo, a função heurística das metáforas sobressai-se nas terminologias de corpora científicos, porquanto elas mediam e conduzem a formação de um novo conceito ou de uma teoria científica, surgindo de uma relação "nova" estabelecida entre dois referentes, de maneira que o sentido se perfaz do "objeto" mais concreto ao abstrato.

As metáforas heurísticas fazem parte do método científico, favorecem novas descobertas ou mesmo o desenvolvimento teórico que ajuda a conceber novas abordagens para problemas conhecidos, funcionando como catalisadoras do pensamento. Um dos exemplos citados nesta pesquisa é o termo capital humano, conceito esse que é de difícil tratamento econômico, pois pode ser compreendido como uma metáfora estrutural ou ontológica.

As imagens projetadas pelos especialistas nesse percurso de denominação dos conceitos se realizam pelos processos de experienciação pela metáfora. No universo da Economia, os empregos metafóricos são provenientes de campos diversos, porém, de acordo com dados tabulados, observamos que uma parte expressiva desses termos fazem referência ao campo da Física e da Biologia.

No discurso científico da Economia, as metáforas terminológicas são estabelecidas pela relação de semelhança entre conceitos desses domínios diversos, a saber, um domínio-fonte e um domínio-alvo. Na Economia, os cientistas valem-se com bastante frequência do campo da Física por razões até mesmo históricas, muito devido ao cientificismo vigente no período em que a Economia estabeleceu-se como ciência. A Biologia, também por essas mesmas razões, é um domínio bastante recorrente pelo fato de essa ciência ser compreendida sobremaneira como um "organismo", conforme podemos observar na Tabela 2 e na análise realizada na Parte III, Capítulo 5, deste trabalho.

Além da função heurística, as metáforas terminológicas da Economia também desempenham uma função didática destinada a um público em vias de especialização -

${ }^{90}$ GIBBS, R. W. The poetics of mind: figurative thought, language and understanding. New York: Cambridge University Press, 1994. 
alunos de graduação e de pós-graduação, por exemplo. Para um de nossos especialistas entrevistados em maio de 2019, professor dr. Ladislau Dowbor, da PUC de São Paulo, as metáforas da Economia têm também uma função didática, pois fornecem "imagens mentais" cujo objetivo é facilitar a visualização de um conceito mais complexo (citamos nesta tese, na seção 6.1, o exemplo do fluxo circular da renda). Ajzental (2015, p. 22) ${ }^{91}$ considera ainda em seu trabalho um outro tipo de função metafórica: a construtiva. Ele afirma que essa função interpreta um mundo desconhecido ou incognoscível (como exemplo, citamos o caso da hipótese mecanicista neoclássica comentado, que entende a Economia como uma máquina, com mecanismo de preços, equilíbrios e elasticidades).

Por último, parece-nos importante sublinhar que, do ponto de vista linguístico, a denominação metafórica é benéfica, porque ela atende à necessidade de economia linguística ao criar um novo sentido para um vocábulo já existente. Nada é indizível ou dizível de forma complexa, pois a metáfora fornece um desenlace linguístico satisfatório pelo fato de ela refletir, de forma nítida e transparente, a interação entre o referente extralinguístico e o linguístico (OLIVEIRA, 2011, p, 160).

\subsection{O processamento das metáforas e a sua função nos corpora especializados da Economia}

Em resumo, podemos concluir; segundo o que já foi demonstrado e analisado ao longo deste trabalho, que os termos metafóricos da Economia em seus corpora especializados são processados analogicamente, sobretudo por domínios-fonte que provêm das ciências exatas e biológicas. Essa tese pode ser comprovada por meio do mapeamento cognitivo realizado nesta pesquisa. Os conceitos apresentados geraram metáforas linguísticas que correspondem às principais formas de compreensão da Economia, oriundas sobretudo da Escola Tradicional, que interpreta essa área de conhecimento a partir de dois grandes conceitos relacionados a noções de "equilíbrio" e de "concorrência". Em Biologia, as analogias estabelecidas são feitas principalmente por meio da Biologia evolucionária com o objetivo de abordar a organização econômica como

\footnotetext{
${ }^{91}$ Essas três funções da metáfora são citadas e comentadas por Ajzental (2015, p. 22) por meio de BOYD, R. "Metaphor and theory change: what is 'metaphor' a metaphor for?" In: ORTONY, A. (Ed.). Metaphor and thought. 2 ed. Cambridge: Cambridge University Press, 1993; e KLAMER, A.; LEONARD, T. C. "So what's an economic metaphor?" In: MIROWSKI, P. (Ed.). Natural images in economics thought: markets read in tooth and claw. Nova York: Cambridge University Press, 1994, p. 20-54.
} 
um processo dinâmico, fruto de interações, competições, mudanças estruturais, escassez de recursos, entre outros elementos.

Os domínios-fonte dessa área de especialidade, que vão além da Física e da Biologia, são relacionados, por exemplo, à náutica ou a movimentos da água, ao belicismo, a metáforas zoomórficas, além das metáforas do contêiner que correspondem a configurações de esquemas imagéticos resultantes da nossa experiência tátil e/ou visual cotidiana de colocar objetos dentro de uma área delimitada e tirá-los dessa zona. Em Economia, essa metáfora é projetada a fim de conceptualizar proteção ou resistência a forças externas, e, nesse sentido, instituições financeiras e econômicas são receptáculos físicos que podem protegê-las (SILVA, 2017, p. 306). Além das metáforas estruturais, estudamos também, devido à sua produtividade, as metáforas orientacionais, cuja função é a de organizar os conceitos de espacialidade revelando aspectos positivos ou negativos de um determinado fator econômico e/ou financeiro para a compreensão de situações de cunho abstrato, como o caso de alta ou baixa liquidez, que trata da conversão rápida ou não de papéis em dinheiro.

Esses principais domínios-fonte que estão, além da Física e da Biologia, projetados para o campo da Economia, demonstram a natureza mais cotidiana das metáforas, ao passo que os domínios-fonte oriundos das ciências exatas e das biológicas revelam a inclinação das metáforas dessa especialidade a um grau de sofisticação ou de ordem mais elaborada ao estabelecerem analogias com essas duas outras ciências imprimindo, dessa maneira, mais cientificidade às suas comparações, que são funcionais, baseadas em similaridades estruturais profundas. ${ }^{92}$

A metáfora cognitiva é um tema que ganhou bastante notoriedade nos últimos anos. Esse fato é patente quando constatamos que alguns especialistas estão notando a sua importância no processo de entendimento de seu "fazer científico". Essa é a percepção de um de nossos especialistas entrevistados, dr. Alberto Ajzental, professor-adjunto do Departamento de Economia da FGV/Easp, ${ }^{93}$ que sentiu a necessidade de discorrer sobre a metáfora em um dos capítulos de seu livro Complexidade aplicada à economia (2017),

\footnotetext{
92 Curtis e Regeluth, 1994, apud Pádua, 2003, em análise de alguns livros didáticos de ciências, puderam observar algumas analogias nesse tipo de corpus. Das analogias mais empregadas, os autores distinguiram basicamente dois tipos: aquelas mais simples, baseadas em similaridades superficiais e outras mais elaboradas, baseadas no que eles chamaram de "relações funcionais". Os pesquisadores observaram uma maior utilidade das analogias quando eram aplicadas em tópicos difíceis e abstratos, sendo funcional.

93 Ajzental também é coordenador do Núcleo de Analytics do Instituto de Finanças da FGV (Ifin/FGV) e pesquisador na FGV do ramo brasileiro do projeto do Supercomputador Watson IBM no Brasil.
} 
pois ele buscava compreender o pensamento dos economistas através das analogias apresentadas por eles.

Para Ajzental (2017), a Economia estabelece essas “comparações” sobremaneira através da Física e da Biologia, ilustradas por projeções metafóricas que dizem respeito a "flores, abelhas", que exercem a função de ilustrar conceitos relacionados à produção em grupo. Contudo nem todas as metáforas que ocorrem nessa área de conhecimento são empregadas de forma adequada, de acordo com esse economista, pois muitas revelam uma falta de consciência na compreensão desses fenômenos. Para ele, por falta de conhecimento cultural e enciclopédico, alguns especialistas produzem algumas analogias de forma "pasteurizada" e "homogeneizada", buscando na cultura norte-americana algumas de suas fontes.

Do ponto de vista discursivo, de acordo com o prof. Ladislau Dowbor, as metáforas usadas na Economia também podem mascarar um jargão de autoimportância, uma vez que se trata de uma área de conhecimento elitizada. Para Dowbor (2019), o emprego dessas metáforas tem como meta ludibriar, "enganar", pois a terminologia empregada pelos especialistas assegura que os leigos não entendam os conceitos de uma determinada área de conhecimento, afastando o público geral de seu exercício cidadão, tratando-se de vaidade intelectual e necessidade de demonstrar erudição relativa a uma espécie de "reserva de mercado" cultural.

Ainda que o objetivo de nosso trabalho não tenha sido o de analisar os aspectos discursivos e ideologizantes das metáforas projetadas pela Economia, torna-se importante manifestar que, por exemplo, no caso das metáforas cujos traços conceptuais são análogos à doença (por exemplo, as metáforas da “crise"), elas servem para despertar e provocar, nos agentes econômicos e políticos um tipo de atenção alarmante, cuja função ideológica mais influente e perversa é a atribuição da culpa a causas externas, imprevisíveis e incontroláveis, ocultando as verdadeiras causas, desculpabilizando as políticas e os sistemas financeiros e econômicos do mundo ocidental, ocultando as responsabilidades dos agentes econômicos e políticos (SILVA, 2013, p. 305).

Em nossa análise, ainda que os termos metafóricos da Economia possam apresentar também a faceta discursiva acima comentada, do ponto de vista de seus aspectos comunicativos, semânticos e cognitivos acreditamos que a maior parte delas exerce uma função pedagógica e sobretudo heurística, uma vez que os mapeamentos de um conjunto de correspondências conceituais entre os elementos de um domínio-fonte para o domínio-alvo revelam algum tipo de compreensão do conceito, que em muitas 
situações, didatizam esses conhecimentos em um processo de interlocução de ensino e aprendizagem no nível da especialização. 


\section{REFERÊNCIAS}

ADORNE, F. C. Terminologia e textos de especialidade na área de políticas culturais no Brasil. Debate Terminológico, n. 8, p. 42-54, jun. 2012.

AJZENTAL, A. Complexidade aplicada à economia. Rio de Janeiro: Editora FGV, 2015. ALMEIDA, G. M. B.; OLIVEIRA; AlUÍSIO, S. M. A Terminologia na era da informática. Ciência e Cultura, Campinas, v. 58, n. 2, p. 42-45, 2006. Disponível em: <http://cienciaecultura.bvs.br/pdf/cic/v58n2/a16v58n2.pdf>. Acesso em: 27 mar. 2017.

ALVES, I. M. A delimitação da unidade lexical nas línguas de especialidade. In: Aspectos epistemológicos e perspectivas científicas da terminologia. Ciência e Cultura, São Paulo, v. 58, n. 2, abr.-jun. 2006.

Glossário de termos neológicos da economia. São Paulo: Humanitas/FFLCHUSP, 2001.

. Em torno de um jargão técnico: o economês. In: URBANO, H. et al. Dino Preti e seus temas. São Paulo: Cortez, 2001, p. 173-7.

. Neologismo: criação lexical. São Paulo: Ática, 2002.

. "Integração de estrangeirismos à língua portuguesa". In: HERNANDES, M. C. et al. (Org.). A língua portuguesa no mundo. São Paulo: FFLCH-USP, 2008.

As denominações da crise econômica mundial no entrecruzamento da Economia e da Medicina. Filologia e língua portuguesa. São Paulo, v. 18, n. 1, p. 43-67, jan./jun. 2016. Disponível em: <http://dx.doi.org/10.11606/issn.2176-9419.v18i1p43-67>. Acesso em: 4 jul. 2017.

AUGER, P. "Essai d'élaboration d'un modèle terminologique/terminographique variationniste". TradTerm, São Paulo, v. 7, p. 183-224, 2001.

BASÍLIO, Margarida (org.). Palavra. Rio de Janeiro: Grypho, 1999, p. 69-80.

BARROS, L. A. Curso básico de Terminologia. São Paulo: Editora da Universidade de São Paulo, 2004.

Aspectos epistemológicos e perspectivas científicas da Terminologia.

Ciência e Cultura, São Paulo, v. 58, n. 2, abr.-jun. 2006. 
BERBER SARDINHA, T. Linguística de Corpus. São Paulo: Manole, 2004. Metáfora. São Paulo: Parábola Editorial, 2007.

Metáforas de teleconferências de negócios. Cadernos de estudos linguísticos, Campinas, v. 50, n. 2, p. 171-88, jul.-dez. 2008.

Questões metodológicas de análise de metáfora na perspectiva da linguística de corpus. Gragoatá, Niterói, n. 26, p. 81-102, sem. 2009.

Register Variation and Metaphor Use: A Multi-dimensional Perspective. In:

Metaphor in Specialist Discourse. Amsterdam: John Benjamins Publishing Company, 2015.

BIDERMAN, M. T. C. Dicionários de termos financeiros e bancários. São Paulo: Disal, 2013.

Teoria linguística: linguística quantitativa e computacional. Rio de Janeiro: Livros Técnicos e Científicos, 1978.

BOOTH, W. Metaphor as rhetoric: the problem of evaluation. In: SACCKS, S. (org.). On metaphor. Chicago: University of Chicago Press, p. 47-70.

BOYD, R. Metaphor and theory change: what is 'metaphor' a metaphor for?. In: ORTONY, A. (Ed.). Metaphor and Thought. 2 ed. Cambridge: Cambridge University Press, 1993.

CABRÉ, M. T. La terminología: teoría, metodología, aplicaciones. Barcelona: Editorial Antártida / Empúries, 1993.

Terminologie e linguistique: la théorie des portes. Terminologie nouvelles. Terminologie et diversitè culturelles, v. 21, 2002.

CAMERON, L. Identifying and Describing Metaphor in Spoken Discourse Data”. In: L. Cameron \& G. Low (Eds.). Researching and Applying Metaphor. Cambridge: Cambridge University Press, 1999, p. 105-32.

CAVALCANTI, F.; PELOSI, A. C. As metáforas animais e suas implicações interacionais. SCRIPTA, Belo Horizonte, v. 20, n. 40, p. 272-85, 2 sem. 2016.

CHARTERIS-BLACK, J.; ENNIS, T. A Comparative Study of Metaphor in Spanish and English Financial Reporting. English for Specific Purposes. Surrey: Pergamon, 2001. 
CIAPUSCIO, G. E. Textos especializados y terminologia. Barcelona: Institut Universitari de Linguística Aplicada, 2008 [Kobo Epub].

COSTA, A. R. O gênero textual artigo científico: estratégias de organização. Disponível em: <http://www.cin.ufpe.br/ 1sc4/snct2011/files/SNCTIFPE_0005.pdf>. Acesso em: 30 jun. 2018.

COSTA, E. A. Um estudo cognitivo das metáforas geradas em um corpus jornalístico da Economia. 2007, 130 f. Dissertação (Mestrado) - Faculdade de Filosofia, Letras e Ciências Humanas, 2007.

CUNHA, A. G. Dicionário etimológico Nova Fronteira da língua portuguesa. Rio de Janeiro: Nova Fronteira, 1982.

DEIGNAN, A. Corpus Linguistic Data and Conceptual Metaphor Theory. In: ZANOTTO, M.; CAMERON, M.; CAVALCANTI, M. C. (ed.). Confronting metaphor in use: an applied linguistic approach. Amsterdam/Philadelphia: John Benjamins North America, 2008, p. 149-62.

FARACO, C. A. Estrangeirismos: guerras em torno da língua. São Paulo: Parábola Editorial, 2004.

FAUCONNIER, G.; TURNER, M. The Way We Think: Conceptual Blending and the Mind's Hidden Complexities. New York: Basic Books, 2002.

Rethinking metaphor. In: GIBBS, R. The Cambridge Handbook of Metaphor and Thought. Cambridge: Cambridge University Press, 2006.

FERRARI, L. Introdução à linguística cognitiva. São Paulo: Contexto, 2016.

FINATTO, M. J. B. Terminologia e Linguística de Corpus: da perspectiva enunciativa aos novos enfoques do texto técnico-científico. Letras de Hoje, Porto Alegre, v. 39, n. 4, p. 97-106, dez. 2004.

CONCEITO DE. Conceito de flutuação. Disponível em: < https://conceito.de/flutuacao >. Acesso em: 10 dez. 2019.

GÓMEZ DE ENTERRÍA, J. Últimas tendencias neológicas en la prensa econômica. In: CABRÉ, M. Teresa; FREIXA, Judit; SOLÉ, Elisabet. La Neologia em el tombant de segle: I Simposi sobre Neologia (18 de desembre de 1998), I Seminari de Neologia (17 febrer de 2000). Barcelona: Institut Universitari de Lingüística Aplicada, 2000. 
GOMES, M. R. V. D. A tradução de textos econômico-financeiros de português para inglês: potencialidades da plataforma ISTRION. 2015, 149 f. Dissertação (Mestrado) Faculdade de Ciências Sociais e Humanas, 2015.

GOMES, O. Dicionário prático de economia. Lisboa: Edições Sílabo, 2015.

KLAMER, A.; LEONARD, T. C. So What's an Economic Metaphor? In: MIROWSKI, P. (Ed.). Natural Images in Economics Thought: markets read in tooth and claw. Cambridge: Cambridge University Press, 1994, p. 20-54.

KOCOUREK, R. La langue française de la technique et de la science. Wisbaden: Bradstetter, 1991.

KRIEGER, M.; FINATTO, M. J. B. Introdução à terminologia: teoria e prática. São Paulo: Contexto, 2016.

KUNTZ, R. Jornalismo econômico - quelle língua ist this one? Observatório da imprensa na Internet, 2006. Disponível em: 〈http://www.tvebrasil.com.br $>$. Acesso em: 14 jul. 2019.

LABATE, F. G. Vocabulário da economia: formas de apresentação dos estrangeirismos. 2008, 136 f. Dissertação (Mestrado) - Faculdade de Filosofia, Letras e Ciências Humanas, Universidade de São Paulo, São Paulo, 2008.

LAKOFF, G.; JOHNSON, M. Metáforas da vida cotidiana. Mara Sophia Zanotto (Trad.). Campinas: Mercado das Letras; São Paulo: Educ, 2002. Título original em inglês: Metaphors We Live By. Chicago: The University of Chicago Press, 1980.

LERAT, P. Las lenguas especializadas. (trad. castelhana de Albert Ribas). Barcelona: Editora Ariel, 1997.

MACEDO, H. Dicionário de Física. Rio de Janeiro: Nova Fronteira, 1976.

MARCUSCHI, L. A. G. Gêneros textuais: o que são e como se constituem. Recife: Universidade Federal de Pernambuco, 2000. [mimeo].

Gêneros textuais: conceituação, constituição e funcionalidade. In: DIONÍSIO, A.; MACHADO, A. R.; BEZERRA, M. A. (orgs.). Gêneros textuais e ensino. Rio de Janeiro: Lucerna, 2002.

MARTINS, C. S. M. A metáfora na terminologia: as metáforas terminológicas nos textos jurídicos de ambiente. 2004, 318 f. Dissertação (Mestrado) - Faculdade de Letras 
Universidade do Porto, Porto. Disponível em: <https://bibliotecadigital.ipb.pt/handle/10198/3767>. Acesso em: 7 set. 2018.

MELO MOURA, H. M. Metáforas e regularidades linguísticas”. In: MIRANDA, N. S.; NAME, M. C. Linguística e cognição. Juiz de Fora: Ed. da UFJF, 2005, p. 109-19.

MINEIRO, A. Uma abordagem lexical da terminologia náutica. Comunicação apresentada no IX Simpósio Ibero-americano de Terminologia. Barcelona, dezembro de 2004. Disponível em: <http://itelc.pt/pdf/wpapers/2006-ara-pub3.pdf>. Acesso em: 15 jan. 2018.

MIGLIAVACCA, P. N. Dicionário de termos de negócios: inglês-português, portuguêsinglês. São Paulo: Edicta, 1999.

MOYANO, E. I. Una clasificación de géneros científicos. Disponível em: $<$ http://web.fuberlin.de/adieu/vazquez/Clasificacion\%20de\%20generos\%20MOYANO. pdf>. Acesso em: 30 jun. 2018.

OLIVEIRA, L. P. de. Aspectos linguísticos, comunicativos e cognitivos das metáforas terminológicas: uma análise baseada em corpus da Genética Molecular. 2011, 176 f. Tese (Doutorado) - Faculdade de Filosofia, Letras e Ciências Humanas, 2011.

OLIVEIRA, I. Nature et fonctions de la métaphore en science. L'exemple de la cardiologie. Paris: L’Harmattan, 2009. [Adobe digital editions].

PÁDUA, I. C. A. Analogias, metáforas e a construção do conhecimento: por um processo de ensino-aprendizagem mais significativo. In: Reunião Anual da Associação Nacional de Pós-Graduação e Pesquisa em Educação: novo governo, novas políticas? Poços de Caldas. Anais eletrônicos. Rio de Janeiro: ANPED, 2003.

PEDERSEN, T.; PATWARDHAN, S. Distance Perl package (Version 0.1). Duluth: University of Minnesota, 2002.

PINHO, M. O. de M. Dicionário de termos de negócios. São Paulo: Atlas, 1997.

RAYSON, P; GARSIDE, R. Comparing Corpora Using Frequency Profiling. In: Proceedings of the Workshop on Comparing Corpora, held in conjunction with the 38th Annual meeting of the Association for Computational Linguistics (ACL 2000). Hong Kong, p. 1-6, 1-8 out. 2000. 
ROSA, L. I. P. de O. Neologia semântica na década de 90: um estudo sobre a metáfora em um corpus jornalístico. 2009, 165 f. Dissertação (Mestrado) - Faculdade de Filosofia, Letras e Ciências Humanas, 2008.

SABLAYROLLES, J. F. La néologie en français contemporaine: examen du concept et analyse de productions néologiques récentes. (Lexica - Mots et Dictionnaires, 4). 2 ed. Paris: Honoré Champion, 2000. 595 p.

SAGER, J. C. In search of foundation: towardas a theory of the terms. Terminology, v. 5, n. 1, p. 45-57, 1999.

SALGADO, A. R. Estudo comparativo entre ferramentas de análise de corpus: WordSmith Tools, AntConc e ambiente e-Termos. In: Pré-Seminário sobre Estudos em Andamento no Campo da Linguística Aplicada, São Leopoldo, Atas do Pré-Seacla, p. 4243, 2011.

SANDMANN, A. J. Morfologia lexical. São Paulo: Contexto, 1992.

SANDRONI, P. Dicionário de economia do século XXI. Rio de Janeiro: Record, 2005.

SCHRÖDER, U. A. Da teoria cognitiva a uma teoria mais dinâmica, cultural e sociocognitiva da metáfora. Alfa, São Paulo, v. 52, n. 1, p. 39-56, 2008.

SILVA, A. S. O que sabemos sobre a crise económica pela metáfora. Conceptualizações metafóricas da crise pela imprensa brasileira. Revista Media \& Jornalismo. Braga, v. 22, n. $1, \quad$ p. $2013.21-34, \quad$ Disponível em: <https://www.researchgate.net/publication/290779369_O_que_sabemos_sobre_a_crise_ economica_pela_metafora_Conceptualizacoes_metaforicas_da_crise_na_imprensa_port uguesa>. Acesso em: 23 ago. 2017.

O poder cognitivo da metáfora e da metonímia. Revista Portuguesa de Humanidades, Braga: Faculdade de Filosofia da U.C.P., v. 7, n. 1/2, p. 13-75, 2003.

SILVA, O. L. da. Das ciências do léxico ao léxico das ciências: uma proposta de dicionário português-espanhol de Economia Monetária. 2008, 335 f. Tese (Doutorado) Araraquara, Faculdade de Ciências e Letras da UNESP, 2008.

SILVA E TEIXEIRA, R. B. Termos de (Onco)mastologia: uma abordagem mediada por corpus. Dissertação (Mestrado). Pontifícia Universidade Católica de São Paulo, 2010. SINGER, P. O que é economia. 7 ed. São Paulo: Contexto, 2014. 
ROSA, L. I. P. de O. Neologia semântica na década de 90: um estudo sobre a metáfora em um corpus jornalístico. 2009, 165 f. Dissertação (Mestrado) - Faculdade de Filosofia, Letras e Ciências Humanas, 2008.

SABLAYROLLES, J. F. La néologie en français contemporaine: examen du concept et analyse de productions néologiques récentes. (Lexica - Mots et Dictionnaires, 4). 2 ed. Paris: Honoré Champion, 2000. 595 p.

SAGER, J. C. In search of foundation: towardas a theory of the terms. Terminology, v. 5, n. 1, p. 45-57, 1999.

SALGADO, A. R. Estudo comparativo entre ferramentas de análise de corpus: WordSmith Tools, AntConc e ambiente e-Termos. In: Pré-Seminário sobre Estudos em Andamento no Campo da Linguística Aplicada, São Leopoldo, Atas do Pré-Seacla, p. 4243, 2011.

SANDMANN, A. J. Morfologia lexical. São Paulo: Contexto, 1992.

SANDRONI, P. Dicionário de economia do século XXI. Rio de Janeiro: Record, 2005.

SCHRÖDER, U. A. Da teoria cognitiva a uma teoria mais dinâmica, cultural e sociocognitiva da metáfora. Alfa, São Paulo, v. 52, n. 1, p. 39-56, 2008.

SILVA, A. S. O que sabemos sobre a crise económica pela metáfora. Conceptualizações metafóricas da crise pela imprensa brasileira. Revista Media \& Jornalismo. Braga, v. 22, n. $1, \quad$ p. $11-34,2013.2$ Disponível em: <https://www.researchgate.net/publication/290779369_O_que_sabemos_sobre_a_crise_ economica_pela_metafora_Conceptualizacoes_metaforicas_da_crise_na_imprensa_port uguesa>. Acesso em: 23 ago. 2017.

O poder cognitivo da metáfora e da metonímia. Revista Portuguesa de Humanidades, Braga: Faculdade de Filosofia da U.C.P., v. 7, n. 1/2, p. 13-75, 2003.

SILVA, O. L. da. Das ciências do léxico ao léxico das ciências: uma proposta de dicionário português-espanhol de Economia Monetária. 2008, 335 f. Tese (Doutorado) Araraquara, Faculdade de Ciências e Letras da UNESP, 2008.

SILVA E TEIXEIRA, R. B. Termos de (Onco)mastologia: uma abordagem mediada por corpus. Dissertação (Mestrado). Pontifícia Universidade Católica de São Paulo, 2010. SINGER, P. O que é economia. 7 ed. São Paulo: Contexto, 2014. 